\author{
Universidade de São Paulo \\ Instituto de Física \\ Instituto de Química \\ Instituto de Biociências \\ Faculdade de Educação
}

\title{
Habilidades cognitivas manifestadas por alunos do ensino médio de química em atividades experimentais investigativas
}

\author{
Rita de Cássia Suart
}

Orientador: Prof. Dra. Maria Eunice Ribeiro Marcondes

Dissertação de mestrado apresentada ao Instituto de Física, ao Instituto de Química, ao Instituto de Biociências e a Faculdade de Educação da Universidade de São Paulo, para a obtenção do título de Mestre em Ensino de Ciências.

São Paulo

2008 
Rita de Cássia Suart

\section{Habilidades cognitivas manifestadas por alunos do ensino médio de química em atividades experimentais investigativas}

Dissertação de mestrado apresentada ao Instituto de Física, ao Instituto de Química, ao Instituto de Biociências e a Faculdade de Educação da Universidade de São Paulo, para a obtenção do título de Mestre em Ensino de Ciências.

Orientador: Prof. Dra. Maria Eunice Ribeiro Marcondes

\section{BANCA EXAMINADORA}

Profa. Dra. Maria Eunice Ribeiro Marcondes (USP)

Profa. Dra. Odete Pacubi Baierl Teixeira (UNESP)

Profa. Dra. Silvia Regina Quijadas Aro Zuliani (UNESP) 


\section{FICHA CATALOGRÁFICA}

\section{Preparada pelo Serviço de Biblioteca e Informação}

do Instituto de Física da Universidade de São Paulo

Suart, Rita de Cássia

Habilidades cognitivas manifestadas por alunos do ensino médio de química em atividades experimentais investigativas - São Paulo - 2008

Dissertação (Mestrado) - Universidade de São Paulo. Instituto de Física, Instituto de Química, Faculdade de Educação e Instituto de Biociências

Orientador: Profa. Dra. Maria Eunice Ribeiro Marcondes

Área de Concentração: Ensino de Ciências

Unitermos: 1. Experimentos científicos; 2. Aptidão cognitiva; 3. Ensino; 4. Ciências. 


\section{Agradecimentos}

À professora Maria Eunice Marcondes, que me acolheu em seu grupo, e depositou sua confiança em mim e em meu trabalho ao longo destes três anos. Sempre atenciosa, me orientou a seguir os melhores caminhos na minha pesquisa. Durante estes anos, algumas frases marcaram os momentos de dúvidas e discussões, como por exemplo: "Melhora isso!", "Não entendi", "Tô pensando...". Agradeço também, aos seus inúmeros rabiscos nos meus rascunhos, que me faziam refletir por horas. Obrigada professora!

Às professoras desta banca examinadora, Silvia R. Q. A. Zuliani e Odete P. B. Teixeira, pela leitura crítica e detalhada deste trabalho.

Às professoras Dayse de Brito Rezende e Salete Linhares de Queiroz, por participarem da minha banca de qualificação com suas preciosas sugestões.

À professora Sônia Barreto, da UEL, que me incentivou a seguir meus estudos em Ensino de Química, e proporcionou o meu primeiro estágio e minhas primeiras aprendizagens como pesquisadora da área.

À amiga Marina, a primeira amizade construída durante o curso, pelas longas conversas no telefone, sempre me acalmando e me aconselhando no que precisava.

Às amigas Miriam e Simone, que sempre estavam dispostas a me ouvir, a ler meus rascunhos; me incentivando em cada decisão tomada.

Em especial, agradeço ao meu marido, que com sua calma, sempre me ouviu e estendeu seu ombro nos momentos que mais precisei, me convencendo que tudo daria certo.

À minha família, que mesmo longe, me apoiou nesta jornada.

Agradeço também aos amigos do grupo: João, Luciane, Daniele, Fábio, Ângela, Dayse e Renata.

Por fim, agradeço a CAPES pelo auxílio financeiro e por acreditar e incentivar a pesquisa em Ensino de Ciências. 


\section{Resumo}

Suart, R.C. Habilidades cognitivas manifestadas por alunos do ensino médio de química em atividades experimentais investigativas. 2008. 218p. Dissertação (Mestrado) Universidade de São Paulo, São Paulo, 2008.

Algumas pesquisas em Ensino de Química têm destacado a importância do uso de atividades experimentais investigativas para o desenvolvimento de habilidades cognitivas nos alunos e para sua maior participação no processo de aprendizagem. Os experimentos investigativos são uma das estratégias sugeridas para alcançar esses objetivos. Assim, se os alunos participarem de etapas como: coleta de dados, análise e discussão; poderão formular hipóteses e propor soluções para o problema proposto, desenvolvendo seu raciocínio lógico e habilidades cognitivas importantes para a construção do conhecimento químico e para a sua formação cidadã. Desta forma, a presente pesquisa investigou as habilidades cognitivas manifestadas por alunos do ensino médio de química em atividades experimentais investigativas. Foram gravadas, em áudio e vídeo, quatro seqüências de aulas desta natureza em duas escolas localizadas na cidade de São Paulo. Três seqüências de aulas foram realizadas em uma mesma escola e conduzidas pela mesma professora. Os conceitos abordados foram: densidade e temperatura de ebulição. O conceito de densidade foi desenvolvido em duas turmas, e o conceito de temperatura de ebulição em somente uma delas. O conceito desenvolvido na outra escola foi o de temperatura de fusão. Respostas escritas e os relatórios elaborados pelos alunos também foram coletados e analisados. As aulas foram transcritas e analisadas qualitativamente utilizando categorias de análise criadas pela pesquisadora, baseadas nas habilidades cognitivas manifestadas pelos alunos. Para a elaboração das categorias de análises, utilizou-se as idéias de Zoller, que classifica as habilidades cognitivas de acordo com o baixo ou alto nível de demanda cognitiva requerida para a solução de um problema, denominadas LOCS (Lower Order Cognitive Skills - Habilidades Cognitivas de Baixa Ordem); ou HOCS (Higher Order Cognitive Skills - Habilidades Cognitivas de Alta Ordem). Verificou-se, grande participação dos alunos nas atividades e manifestação de habilidades cognitivas de alta ordem, como elaboração de hipóteses e análise de variáveis, porém, grande parte das respostas foi classificada como habilidades cognitivas de baixa ordem. Entretanto, o nível de habilidades cognitivas manifestadas pelos alunos está relacionado com o nível cognitivo das questões propostas pelo professor. A análise das respostas escritas dos alunos também evidencia habilidades cognitivas de alta ordem, porém, os alunos apresentam certa dificuldade em sintetizar suas idéias e as expressarem por escrito. Os resultados também mostram que o papel do professor é de suma importância ao questionar e propor desafios aos alunos para que estes possam propor suas próprias hipóteses e propor possíveis soluções para o problema.

Palavras-chave: habilidades cognitivas, experimentação, ensino de química 


\begin{abstract}
Suart, R.C. Cognitive skills revealed by secondary education students in investigative laboratory work. 2008. 218p. Dissertation (Master's degree). Universidade de São Paulo, São Paulo, 2008.
\end{abstract}

Some studies in Chemistry Teaching have focused the importance of the use of investigative laboratory work to develop students' cognitive skills to increase the participation in the learning process. So, if the students are involved in steps as: data collection, analysis and discussion, they will be able to formulate hypothesis and to propose solutions to the problem, developing logical reasoning and cognitive skills important to the construction of chemical knowledge and for citizenship. This work investigated the cognitive skills expressed by secondary education students in investigative experimental chemistry activity. The sequences of four inquiry classes carried out in two schools localized in São Paulo were recorded on audio e videotape. Three sequences of classes were conduct by a teacher in one of these schools and the concepts developed were: density and boiling point, in the other school the concept studied was melting point. The reports and the written answers were also colected and analysed. The classes were transcripted and analised qualitatively using the categories developed by this researcher, based on the cognitive skills expresed by the students. Zoller's ideas guided the development of the categories. According to him, the cogntive skills may be classified as LOCS and HOCS, based on the cogntive demand claim to answer a question. The results show great involvement of the students in the activity and their answers reveal higher order cognitive skills, such as development of hypothesis; however, they also give answers that were classified as lower order cognitive skills. The analysis of the written answers evidenced higher order cognitive skills; however, the students present some dificults to synthesize their ideas and to express them in their writing. The results also show that the teacher's mediation is very important to conduct questions and challenges in order to allow the students to elaborate hypothesis and to propose solutions to the problem.

Keys-word: cognitive skills, laboratory work, chemistry teaching 


\section{Sumário}

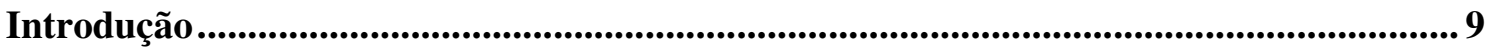

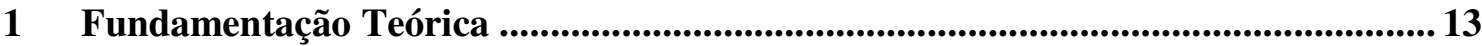

$1.1 \quad$ O Construtivismo e o Ensino de Química ............................................................ 13

1.2 O papel das atividades experimentais no Ensino de Química .............................. 16

1.3 Algumas concepções que orientam as atividades experimentais .......................... 28

2 Revisão Bibliográfica ........................................................................................ 40

2.1 A utilização do laboratório no Ensino de Química ............................................... 40

2.2 Pesquisas sobre atividades experimentais investigativas e habilidades cognitivas no

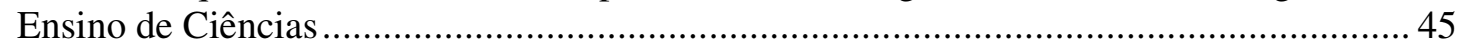

3 Metodologia da Pesquisa....................................................................................61 61

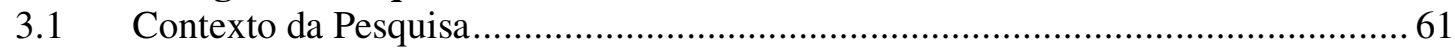

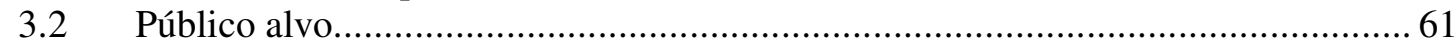

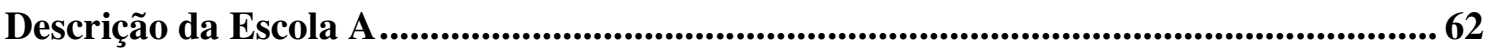

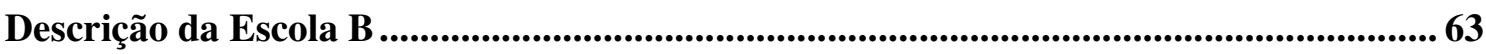

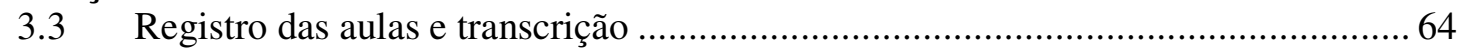

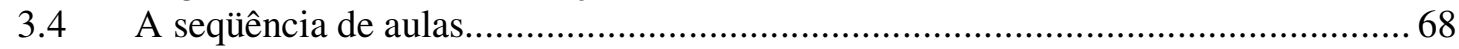

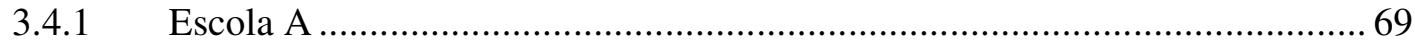

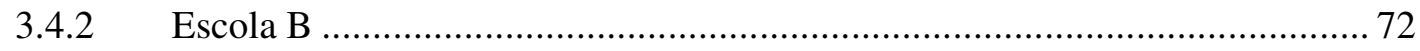

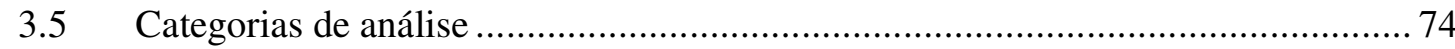

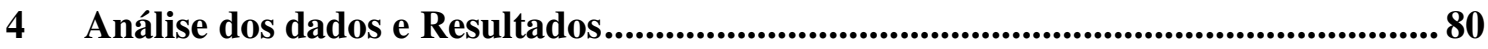

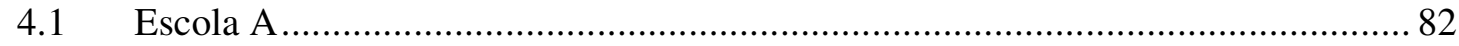

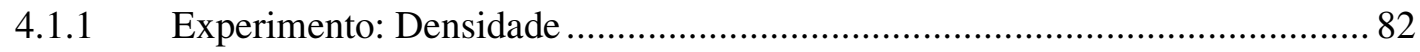

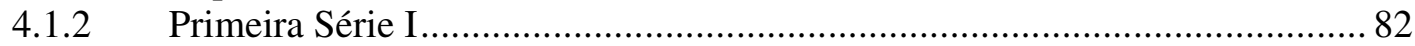

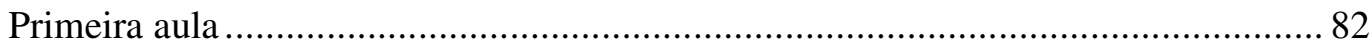

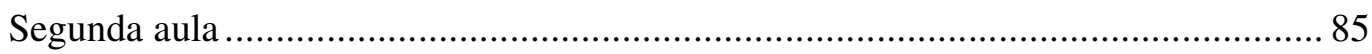

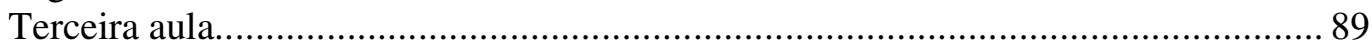

A atividade experimental realizada pelos alunos ............................................... 92

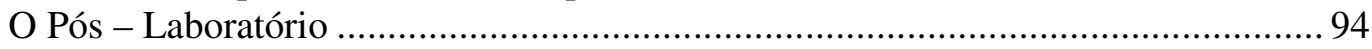

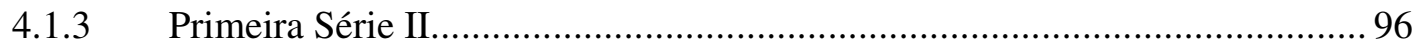



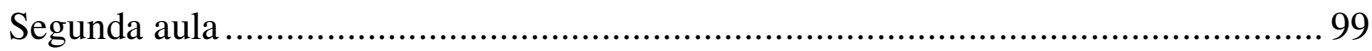

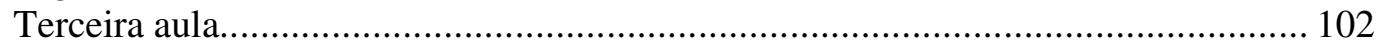

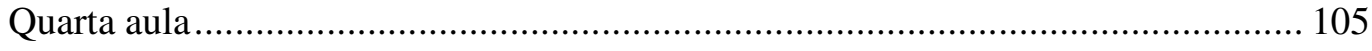

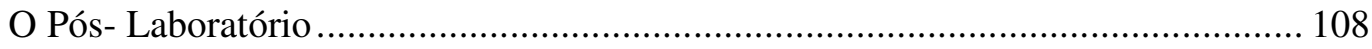

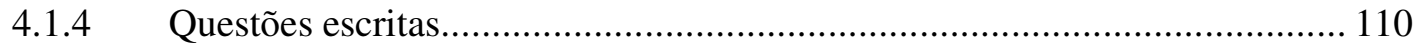

4.1.5 Considerações sobre a atividade experimental investigativa: Densidade...... 119

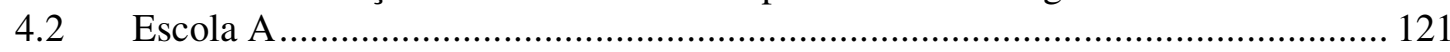

4.2.1 Experimento: Temperatura de Ebulição ................................................. 121

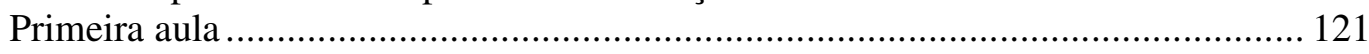

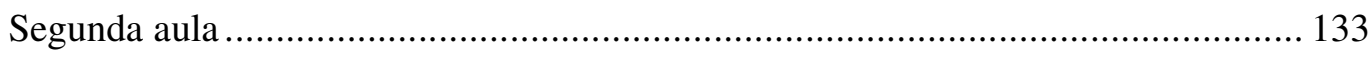

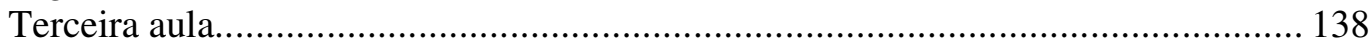

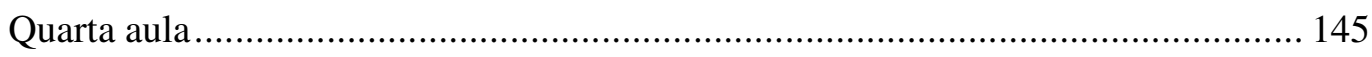

4.2.2 Consideração sobre a atividade experimental investigativa: T. E............... 148

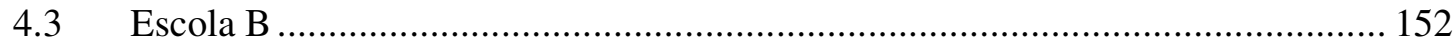


4.3.1 Experimento: Temperatura de Fusão......................................................... 152

Primeira aula - Execução do experimento …...................................................... 152

Segunda aula - Elaboração dos gráficos ............................................................ 154

Terceira aula - Análise dos dados e conclusões ............................................... 156

Quarta aula - Questões para discussão ............................................................... 161

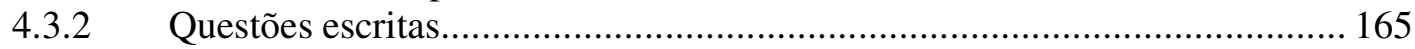

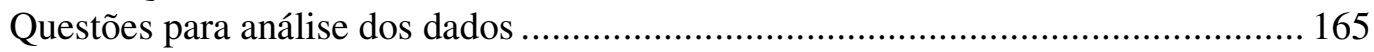

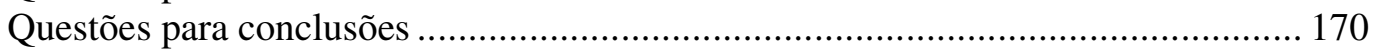

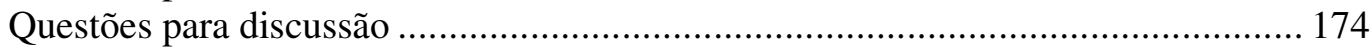

4.3.3 Considerações sobre a atividade experimental investigativa: T.F................ 176

5 Considerações finais .......................................................................................... 179

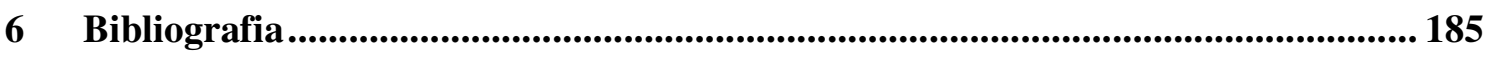

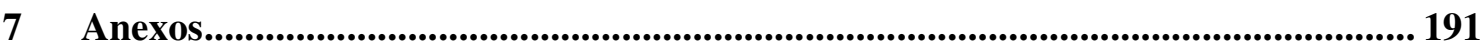




\section{Introdução}

As pesquisas em Ensino de Ciências têm evidenciado diversas causas para o fracasso no processo de ensino e aprendizagem. A procura por metodologias que priorizem a participação do aluno na construção dos conceitos científicos e no desenvolvimento de habilidades cognitivas e atitudinais tem se tornado meta central para pesquisadores e professores.

As atividades experimentais são uma das estratégias mais utilizadas nas escolas e também uma das mais pesquisadas nestes últimos trinta anos, e são consideradas uma aliada para melhores resultados no processo de ensino e aprendizagem de ciências, ou mais especificamente de Química. Há uma vasta gama de artigos e livros defendendo a experimentação no ensino de química, porém o que se tem percebido, de um modo geral, é que muitos desses trabalhos apresentam críticas ao modo pelo qual essas atividades têm sido propostas e executadas em sala de aula.

As atividades experimentais, tanto no ensino médio como em muitas universidades, são tratadas de forma acrítica e aproblemática. Pouca oportunidade é dada aos alunos para que se engajem no processo de coleta de dados, análise e elaboração de hipóteses, os quais contribuem para o desenvolvimento e manifestação de habilidades cognitivas de alta ordem. O professor, na grande maioria das vezes, é o detentor do conhecimento e a ciência é tratada de forma empírica e algorítmica. O aluno é o agente passivo da aula e a ele cabe seguir um protocolo proposto pelo professor para a atividade experimental, elaborar um relatório e tentar ao máximo se aproximar dos resultados já esperados. Esta postura, comum em muitas salas de aula, não valoriza a interação professor-aluno, e muitas vezes, o processo de ensino e aprendizado é penalizado e a atividade experimental pode não alcançar todas as suas potencialidades.

Além dessa postura tradicionalista manifestada por muitos professores, devido, em parte, às suas crenças epistemológicas e ontológicas, outros fatores são citados por eles para a ineficácia das atividades experimentais, como: falta de laboratório; falta de materiais a reagentes; falta de laboratorista; falta de tempo para elaboração e execução das atividades; falta de um material de apoio; entre outros fatores que poderíamos aqui assinalar ao revisar a bibliografia. 
Entretanto, a grande maioria dos professores reconhece que as atividades experimentais são de extrema importância para o processo de aprendizagem no ensino de ciências e citam esta estratégia de ensino como uma das mais (ou a mais) motivadoras e eficazes no ensino. Mas, muitas vezes, é dado à experimentação um papel que não cabe só a ela, o de solucionar os problemas de aprendizagem. Muitos professores atribuem às atividades experimentais a solução dessas dificuldades e acabam limitando alguns de seus pontos positivos, como construção de conceitos; desenvolvimento de habilidades cognitivas, atitudinais e de reflexão, entre outras promotoras do desenvolvimento cidadão.

A postura construtivista, disseminada nos últimos trinta anos, tem como marco central a participação do aluno no processo de construção do conhecimento e o professor como mediador ou facilitador desse processo. Pesquisas atuais defendem propostas construtivistas de ensino e aprendizagem, mudando o foco deste processo para a figura do aluno.

Embora não existam respostas definitivas sobre a maneira pela qual ocorre a aprendizagem, as evidências apontam para estratégias que valorizam a participação ativa do aluno na resolução de situações problemáticas, possibilitando-o a predizer respostas, testar hipóteses, argumentar, discutir com os pares, podendo atingir a compreensão de um conteúdo. Entretanto, o papel do professor como mediador do processo de ensino e aprendizagem não pode ser depreciado, ao contrário, a sua intervenção é de suma importância para auxiliar os alunos na construção de suas idéias, as quais são muitas vezes manifestadas de maneira incompleta ou sem sentido em um primeiro momento.

Assim, ao se defender o construtivismo, ou atividades de natureza construtivista, defende-se uma atividade na qual as interações sociais e cognitivas entre professor e alunos sejam constantes e mútuas, contribuindo progressivamente para o processo de aprendizagem.

Fica evidente a necessidade de se investir na proposição de metodologias e estratégias capazes de proporcionar o desenvolvimento cognitivo do aluno e o desenvolvimento e manifestação de habilidades cognitivas de alta ordem; e a experimentação em química é considerada uma destas estratégias. (CARVALHO et al., 1999; ZOLLER, 1993).

Existem várias propostas de ensino e aprendizagem à procura de melhores resultados para a experimentação no ensino de ciências. Uma delas é a proposta 
defendida por Carvalho et al. (1999), a qual prioriza a participação do aluno na construção do conhecimento por meio de atividades experimentais investigativas. Essas atividades podem ser demonstradas pelo professor ou realizadas pelos alunos, tendo como principal objetivo priorizar a discussão, elaboração de hipóteses, análise dos dados, apoiados sempre pelo professor mediador.

De acordo com Carvalho et al. (1999), para que a atividade experimental apresente caráter investigativo e possa ser considerada uma atividade de investigação, a ação do aluno não deve se limitar apenas ao trabalho de manipulação ou observação. A resolução de um problema pela experimentação deve envolver também reflexões, relatos, discussões, ponderações e explicações características de uma investigação científica.

Assim, se uma aula experimental for organizada de forma a colocar o aluno diante de uma situação problema e estiver direcionada para a resolução deste problema, poderá contribuir para o aluno raciocinar sobre a situação e apresentar argumentos na tentativa de analisar os dados e apresentar uma conclusão plausível.

Se o estudante tiver a oportunidade de acompanhar e interpretar as etapas da investigação, ele poderá ser capaz de elaborar hipóteses, testá-las e discuti-las, aprendendo sobre os fenômenos químicos estudados e os conceitos que os explicam, alcançando os objetivos da uma aula experimental que privilegia o desenvolvimento de habilidades cognitivas e de raciocínio lógico.

Tendo em vista os propósitos educativos de se utilizar atividades experimentais problematizadoras, que promovam aspectos como elaboração de hipóteses, análise de dados e obtenção de conclusões, a presente pesquisa investigou as habilidades cognitivas manifestadas por estudantes do ensino médio de química em atividades experimentais investigativas.

Partiu-se da seguinte premissa: se as atividades práticas forem propostas de forma com que o aluno participe ativamente do processo de coleta de dados, análise e discussão, ele poderá ser capaz de formular hipóteses, atingir uma solução condizente com o problema exposto estruturando suas explicações para o fenômeno químico, desenvolvendo seu raciocínio lógico e habilidades cognitivas necessárias para a construção de conceitos científicos.

Para que o campo de investigação se limitasse a esse tipo de atividade, os professores das escolas investigadas deveriam, através de um questionário, classificar as atividades elaboradas e executadas por eles como construtivistas e investigativas. Assim, nenhuma comparação entre diferentes abordagens foi 
realizada. Através da análise das aulas e de respostas e relatórios elaborados por escrito pelos alunos, foi possível avaliar as potencialidades desta atividade quanto à manifestação de habilidades cognitivas e as implicações e contribuições desta abordagem no ensino de química.

Desta forma, para o entendimento dos pressupostos que contemplam a pesquisa e também os referenciais que a fundamentam, o presente trabalho está organizado da seguinte maneira: no primeiro capítulo, denominado fundamentação teórica, apresenta-se uma introdução sobre a perspectiva construtivista defendida neste trabalho. Depois, realiza-se uma revisão sobre o papel da experimentação no ensino de ciências e de química, discutindo alguns de seus principais objetivos e limitações, e as principais concepções que orientam as atividades experimentais, enfatizando as atividades experimentais investigativas, foco desta pesquisa.

No segundo capítulo apresenta-se uma revisão bibliográfica realizada para corroborar a importância desta pesquisa e também para avaliar resultados obtidos por outros pesquisadores. Na parte inicial, realiza-se uma breve revisão sobre a história da utilização da experimentação no ensino de química e, em seguida, apresentam-se resultados obtidos na revisão de diversas pesquisas que contemplam a abordagem experimental.

O terceiro capítulo apresenta a metodologia utilizada para a pesquisa, os instrumentos e metodologia de análise. O quarto capítulo apresenta os resultados obtidos pela pesquisa ao se analisar seqüências de aulas investigativas em duas escolas públicas de São Paulo, juntamente com a discussão dos resultados, pautados nos referencias teóricos. No quinto capítulo, apresentam-se as considerações finais.

Assim, este trabalho pôde, de certa forma, contribuir para uma reflexão quanto ao estilo de experimentação executada em sala de aula, fortalecendo a argumentação a favor de atividades experimentais desenvolvidas em um ambiente construtivista e investigativo, favorecendo o desenvolvimento de habilidades cognitivas de alta ordem nos alunos. 


\section{Fundamentação Teórica}

\subsection{O Construtivismo e o Ensino de Química}

O Ensino de Ciências, ou mais especificamente, o Ensino de Química, aproximadamente até a década de setenta, não era tratado com a devida importância. A imagem tradicional do ensino como transmissão de conhecimentos privilegiava a amplitude e a profundidade do conhecimento do docente relacionandoas diretamente com a qualidade da aprendizagem dos estudantes (VILLANI; PACCA, 1997). Assim, para ensinar, bastava o professor saber o conteúdo a ser ensinado e algumas técnicas pedagógicas.

Sob esta perspectiva, o ensino estava centrado na retenção de enormes quantidades de informações por parte dos alunos e que deveriam ser devolvidas sob os mesmos termos nas avaliações escritas (SCHNETZLER; ARAGÃO, 1995). O aluno era visto como uma "tábula rasa" isento de pré-concepções, e o professor era considerado o detentor do conhecimento, tornando-se assim o processo ensinoaprendizagem um modelo de transmissão-recepção (SCHNETZLER; ARAGÃO, 1995).

A partir da década de setenta, as pesquisas começam a mostrar preocupações sobre o conteúdo das idéias dos estudantes em relação aos conceitos científicos aprendidos na escola (MORTIMER, 1996). Essa preocupação surge juntamente com projetos como o BSCS, PSSC, CHEM ${ }^{1}$, interessados em despertar a atenção dos estudantes pelas carreiras científicas e envolvê-los de forma mais efetiva no processo de aprendizagem. Estas propostas eram baseadas em uma abordagem de aprendizagem por descoberta, e defendiam a atividade autônoma do indivíduo na construção do conhecimento científico. Além disso, estas propostas também se fundamentavam em concepção empírico-indutivista, a qual destaca o papel "neutro" da observação e da experimentação, não se atendo ao papel das hipóteses norteadoras das investigações científicas, nem às influências sociais que a pesquisa e os pesquisadores estão sujeitos. Assim, as teorias seriam descobertas a partir de dados empíricos oriundos da observação.

\footnotetext{
${ }^{1}$ BSCS - Biological Sciences Curriculum Study; PSSC - Physical Science Study Commitee; CHEM Study National Science Foundation (US) - Chemical Education Material Study.
} 
Vários autores criticam estas concepções ao argumentarem que essas visões desvalorizam o trabalho científico e levam os alunos a tomar o conhecimento cientifico como um corpo de verdades inquestionáveis (GIL-PÉREZ, 1996). Assim, atividades baseadas nesses fundamentos se tornariam pedagogicamente inexecutáveis, pois, sugerir que o aluno seja capaz de descobrir por observação algo que não está preparado conceitualmente para descobrir, seria uma maneira ingênua de compreender a aprendizagem e a construção do conhecimento científico (HODSON, $1996^{2}$ apud DOMIN, 1999a).

$\mathrm{Na}$ década de oitenta, começam a ser desenvolvidas pesquisas sobre as idéias dos alunos. Estas pesquisas foram influenciadas por trabalhos de Piaget, Ausubel, Kuhn e Lakatos, que implícita ou explicitamente, apresentavam a idéia de que os conhecimentos (cotidianos ou científicos) correspondem a construções ${ }^{3}$ da mente humana e não a descrições objetivas da realidade concreta, assim o conhecimento seria construído pelo indivíduo, pela interação entre elementos internos e externos da mente do aprendiz. Propostas de ensino pautadas nestas concepções começaram a surgir sob o rótulo de "construtivismo" (BASTOS et al., 2004).

No construtivismo, a atenção do professor está voltada às potencialidades e dificuldades dos alunos no processo de aprendizagem. Para Ogborn (1997), quatro pontos podem ser usados para caracterizar o construtivismo: (1) a importância do envolvimento ativo do aprendiz; (2) o respeito pelo aprendiz e por suas próprias idéias; (3) o entendimento da ciência enquanto criação humana; (4) orientação para o ensino no sentido de capitalizar o que os estudantes já sabem e dirigir-se às suas dificuldades em compreender os conceitos científicos em função de sua visão de mundo.

Na perspectiva construtivista, o indivíduo já não é mais considerado uma folha em branco, pelo contrário, suas idéias prévias são o ponto de partida para o desenvolvimento do conhecimento (TEIXEIRA,1992). O aluno é agente ativo do processo de construção do conhecimento e o professor assume o papel de mediador entre os novos conceitos e os conceitos já existentes na mente do aprendiz.

\footnotetext{
${ }^{2}$ HODSON, D. Laboratory work as scientific method: three decades of confusion and distortion. Journal of Curriculum Studies, 28 (2), p.115-135, 1996.

${ }^{3}$ Grifo do autor, Bastos.
} 
Para Moraes (2005), caracterizar o construtivismo é algo complexo, uma vez que se trata de algo em permanente construção. Para o autor, o que se pode afirmar sobre o construtivismo é que ele não é uma técnica ou um receituário, mas uma forma de superar a racionalidade técnica da docência, colocando o professor como sujeito ativo de sua prática e refletindo sobre a sua ação docente. Nas palavras de Moraes (2005, p.118):

Assumir uma perspectiva construtivista ou interacionista, portanto, é superar, de um lado, o empirismo, a crença de que o conhecimento se origina do meio, impondo-se de certo modo ao indivíduo; de outro lado, é também superar o apriorismo ou inatismo, posição que coloca toda ênfase nas estruturas inatas do indivíduo. Para o construtivista, o conhecimento não se adquire, nem por imposição do meio, nem por forças inatas do sujeito. O conhecimento necessita ser adquirido por interação do sujeito com o meio, devendo este meio ser entendido tanto no sentido físico como social.

O autor ainda argumenta que para uma prática construtivista é preciso que 0 professor adote algumas atitudes, tais como: (1) atitude pesquisadora: o professor é um pesquisador de sua prática docente, agindo de forma a conhecer cada vez mais seu aluno e desafiá-lo em direção a um conhecimento que ainda não domina; (2) atitude questionadora: ser capaz de mediar a construção de um conhecimento novo com um já existente, fazendo esta mediação a partir do diálogo onde o aluno é constantemente solicitado a participar e refletir; (3) flexibilidade: não se trata de um processo sem direcionamento, mas uma forma de o professor adaptar-se às necessidades dos alunos e às circunstâncias do processo de aprendizagem, afastando-se de procedimentos excessivamente rígidos e pré-planejados.

Ainda para o autor, além do conjunto de atitudes ou modos de ser, descritos acima, considerados necessários para uma prática construtivista, o professor, nesta perspectiva, precisa considerar também os seus modos de ação: (1) mediação: atividades propostas pelo professor para possibilitar aos alunos avançarem do conhecimento que já dominam em direção a novos domínios, podendo ser feita pelo professor e pelos próprios colegas; (2) problematização: transformar o conteúdo aprendido em problemas significativos para os alunos; (3) interdisciplinaridade: superação dos limites estreitos de uma área específica; (4) diálogo: valorizar a fala do aluno, pois a aprendizagem é construída, em partes, a partir de um discurso coletivo, o que pode contribuir para o processo reflexivo e ativo do aluno.

Assim, podemos perceber que adotar uma postura construtivista em sala de aula exige certas atitudes, muitas vezes não comuns na ação de alguns docentes. 
Exige superar algumas crenças ontológicas e epistemológicas enraizadas muitas vezes em concepções trazidas durante toda uma trajetória acadêmica baseada em princípios tradicionalistas. Os professores geralmente se distanciam dos conhecimentos pedagógicos aceitos pela comunidade científica e acabam manifestando suas concepções sobre ensino, aprendizagem e alunos segundo um "pensamento docente de senso comum", frutos de uma formação "ambiental", que se constroem desde suas experiências como alunos nas séries iniciais até a sua formação como professor (CARVALHO; GIL-PÉREZ, 1995). Assim, o professor, além de dominar o conteúdo específico, precisa estar ciente das atitudes e ações que deve tomar para planejar e orientar a sua aula sob a perspectiva construtivista.

Deve-se dar oportunidade para que os alunos utilizem as novas idéias em várias situações, empregando recursos como: experimentos, demonstrações, exemplos, contra-exemplos, de forma a fazer com que os alunos percebam a utilidade e importância do novo conhecimento e a necessidade de (re) interpretar ou (re) construir suas idéias (TEIXEIRA, 1992).

A partir das características apresentadas, percebe-se que na abordagem construtivista, apesar de o aluno ser o agente responsável pela construção do conhecimento, o papel do professor é de extrema importância para intermediar essa construção, uma vez que muitos alunos precisam dessa intervenção para alcançar respostas adequadas para as situações problemas. Assim, o professor propõe situações para o processo de ensino e aprendizagem de forma a procurar alcançar a aprendizagem significativa ${ }^{4}$ do aluno.

\subsection{O papel das atividades experimentais no Ensino de Química}

A Química é uma ciência experimental, e o uso do laboratório para seu estudo é de fundamental importância. Essa afirmação é de fácil confirmação quando nos referimos ao ensino universitário, onde o objetivo é a formação de químicos e pesquisadores, porém quando nos referimos ao ensino médio, a maneira como a experimentação é utilizada é questionável ou sua inserção no ensino é até mesmo inexistente.

\footnotetext{
${ }^{4}$ Entende-se o termo aprendizagem significativa como a aprendizagem que expressa significado para o aluno, e não como uma apropriação do termo utilizado por Ausubel.
} 
As pesquisas em Ensino de Química vêm crescendo nos últimos trinta anos, e um tema muito abordado e discutido é a utilização do laboratório como estratégia de ensino. Algumas destas pesquisas mostram que a experimentação ainda é pouco utilizada por professores de Química do ensino médio e quando empregada é de maneira acrítica e deficiente, indicando uso de metodologias fundamentadas na concepção indutivista e valorizando aspectos como manipulação de materiais, demonstração e comprovação de teorias. (HODSON 1994; GIL-PÉREZ; VALDÉS CASTRO, 1996; GONZÁLES, 1992; GARCIA BARROS; MARTINEZ LOSADA; MONDELO ALONSO, 1995; WATSON; PRIETO; DILLION, 1995).

Atividades experimentais desenvolvidas dessa maneira, de forma a pouco privilegiar aspectos cognitivos, não contribuem para o desenvolvimento de habilidades essenciais para o exercício da cidadania pelos alunos e também para a construção de conceitos químicos.

As pesquisas em ensino procuram elaborar metodologias e estratégias que visam a alfabetização científica dos alunos. Entende-se aqui por alfabetização científica, uma educação que desenvolva conhecimentos científicos para a resolução de problemas, e que estes entendimentos estejam relacionados com as questões sócio-econômicas e ético-morais da ciência e da tecnologia, contribuindo conceitualmente e eticamente para a formação de cidadãos na tomada fundamentada de decisões (GIL-PÉREZ et al., 2005). Essa visão não pretende aproximar a cultura científica da formação de mini-cientistas, uma vez que essa última perspectiva transmite uma visão deformada e empobrecida da ciência, podendo algumas vezes contribuir para a rejeição da atividade científica por parte dos estudantes.

O que se busca com a cultura científica é permitir a inserção dos alunos nos acontecimentos das ciências, das tecnologias e de suas conseqüências. Permitir e criar oportunidades para que nossos alunos possam opinar e ter confiança ao expor suas idéias cientificamente elaboradas para a sociedade, frente às decisões tomadas por poucos. Mas, nem só a formação científica é suficiente. A ética e a moral precisam caminhar juntamente com a tomada fundamentada de decisões. Segundo Gil-Pérez e colaboradores (2005, p.25)

[...] mais do que um nível de conhecimento muito elevado, a vinculação de um mínimo de conhecimentos específicos, perfeitamente acessível a todos, 
com abordagens globais e considerações éticas que não exigem especialização alguma.

Assim, a procura por metodologias que contemplem essas habilidades se torna cada vez mais evidente. A necessidade de desenvolver em estudantes o raciocínio crítico e a tomada de decisões são um dos principais objetivos do ensino de ciências, além, é claro, da construção de conceitos, e a atividade experimental é sugerida como uma estratégia capaz de tornar esses objetivos uma realidade.

Porém, observa-se uma recusa de alguns estudantes à aprendizagem das ciências. A escola muitas vezes acaba mostrando um único "método científico" para os alunos. Essas visões empobrecidas, muitas vezes desencorajam ou desestimulam esses estudantes no processo de aprendizagem das ciências. A apresentação da Ciência como método infalível, individualista, enraizada em concepções positivistas e empíricas, pode gerar nos alunos visões distorcidas sobre o que é a investigação científica e o trabalho dos pesquisadores e cientistas, distanciando os alunos da construção e evolução dos conhecimentos científicos.

O currículo das escolas e a própria concepção de um método científico por parte dos professores contribuem para que os alunos possam distorcer a imagem das ciências. Algumas visões deformadas da ciência mais comuns, segundo GilPérez e colaboradores (2005), são:

- Visão descontextualizada e neutra: parece não haver interesses e influências da sociedade, esquecendo-se dimensões essenciais das atividades científica e tecnológica;

- Concepção individualista e elitista: os conhecimentos científicos aparecem como obra de gênios isolados, ignorando-se o papel do trabalho coletivo, dos intercâmbios entre equipes, essenciais para favorecer a criatividade necessária para abordar situações abertas;

- Concepção empírico-indutivista: concepção que defende o papel da observação e da experimentação "neutra", esquecendo o papel essencial das hipóteses como norteadoras das investigações e dos corpos de conhecimento;

- Visão rígida, algorítmica e infalível: o método científico é apresentado como uma seqüência de etapas definidas, em que, as "observações" e as 
"experiências rigorosas" desempenham um papel contribuindo com a "exatidão e objetividade" dos resultados obtidos;

- Visão aproblemática e a-histórica: transmissão de conhecimentos já elaborados, ignorando quais foram os problemas que se pretendiam resolver, a evolução dos conhecimentos, as dificuldades encontradas e as perspectivas;

- Visão exclusivamente analítica: não se propõe a possível vinculação do problema abordado a diferentes campos da ciência;

- Visão acumulativa: nenhuma menção de como o novo "descobrimento" afeta o corpo de conhecimentos.

A concepção de método científico como uma seqüência de etapas definidas e infalíveis, ainda muito disseminada nas escolas, pode ser percebida nas atividades laboratoriais onde, muitas vezes, apresentam-se os experimentos com a pretensão de criar a ilusão de que seguindo o método científico obtêm-se resultados análogos aos dos cientistas. É preciso deixar claro para os alunos que não existe um único método científico e que a atividade não ocorre de forma isolada, padronizada, neutra de valores e pré-concepções. Os professores precisariam refletir sobre suas concepções de método científico de forma a não induzir seu aluno à mesma concepção distorcida. Segundo Gil-Pérez et al. (2005, p.53)

As concepções docentes sobre a natureza da ciência e a construção do conhecimento científico seriam, pois, expressões dessa visão comum, que nós os professores de ciências aceitaríamos implicitamente devido à falta de reflexão crítica e a uma educação científica que se limita, com freqüência, a uma simples transmissão de conhecimentos já elaborados.

As atividades experimentais, muitas vezes, não contemplam a relação teoriaprática, que é tratada como uma via de mão única, na qual a prática comprova a teoria ou vice versa (ZANON; SILVA, 2000). Atividades deste tipo, que privilegiam a ciência como verdade definitiva, estão apoiadas em concepções empírico-indutivista, e podem contribuir para a formação de um indivíduo com poucas argumentações, que reproduz somente o que lhe foi transmitido.

Hodson (1988) alerta para os cuidados com relação à maneira como as atividades experimentais são conduzidas. $\mathrm{O}$ autor argumenta que é criado um mito de que a observação e o experimento fornecem dados objetivos, confiáveis e independentes de teorias, dos quais surgem as generalizações e por fim as 
explicações teóricas. Dessa forma, o aluno atribui uma importância excessiva aos dados experimentais, como se esses dados pudessem isoladamente conduzir a uma teoria e serem facilmente validados.

O autor ainda defende que os experimentos na ciência são muito mais que simples observações e coleta de dados, mas sim, um processo onde as hipóteses geradas serão rigorosamente testadas e avaliadas, contribuindo para a construção e reconstrução de teorias.

Dessa forma, os professores precisam estar atentos com a forma como desenvolvem seus experimentos, principalmente quando a intenção é equiparar o trabalho científico à experimentação em sala de aula, uma vez que o objetivo dos experimentos nas ciências é o de desenvolver teorias, e já os experimentos no ensino de ciências, apresentam diversos objetivos pedagógicos. Corroborando essa idéia, Hodson (1988, p.62) argumenta

\begin{abstract}
Por exemplo, muitos experimentos em classe não "funcionam", ou dão resultados inesperados. Ainda assim se sugere que os alunos aceitem uma teoria com a qual esses experimentos manifestamente não estão de acordo, atribuindo-se quaisquer anomalias a técnicas inadequadas ou à falta de sorte. Isto ocorre porque a função pedagógica de muitos "experimentos" no ensino da ciência é ilustrar um ponto de vista teórico em particular, ao passo que na ciência o propósito é auxiliar o desenvolvimento de teorias. A intenção de promover uma visão particular, enquanto se mantém uma fachada de investigação aberta, cria enormes dificuldades e é a principal responsável pelas visões distorcidas que os alunos têm a respeito dos experimentos e da metodologia científica.
\end{abstract}

Muitas atividades experimentais são desenvolvidas nas escolas apoiadas nessas concepções. Ensinar ciências é muito mais do que introduzir conceitos prédeterminados, mas sim, contribuir para a reflexão dos alunos quanto às idéias apresentadas a eles.

O papel das hipóteses é de fundamental importância nas atividades experimentais, pois pode exigir capacidade criativa e elaboração conceitual por parte dos alunos. A elaboração de hipóteses exerce um papel essencial para a construção do conhecimento científico pois está vinculada à elaboração de estratégias para a coleta e análise de dados e conseqüentemente à resolução de uma situação problema. É preciso haver previsões plausíveis de serem investigadas à luz do quadro teórico para se analisar os dados. Assim, a elaboração de hipóteses exige grande demanda cognitiva e pode contribuir para o desenvolvimento conceitual do aluno. 
Numa perspectiva racionalista da ciência, segundo Gil-Pérez et al. (2005, p.98), a experiência científica enquanto programa de investigação deve ser guiada por uma hipótese, uma vez que

Trata-se de um diálogo entre hipóteses/teorias e a própria experimentação, diálogo nem sempre simples, já que, também aqui, o confronto entre o teórico (o idealizado) e a prática (o realizado) se interligam.

Podemos perceber, desta forma, a importância de planejar e executar atividades experimentais que privilegiem a elaboração de hipóteses pelos alunos e os cuidados ao tentar aproximar essa atividade de uma pesquisa científica, principalmente quando esta apresenta características empiristas.

As atividades experimentais propostas para que o aluno participe ativamente do processo de coleta de dados, análise, discussão, elaboração de hipóteses, ou seja, que estejam planejadas com o objetivo de explorar habilidades cognitivas, podem contribuir para o desenvolvimento do raciocínio lógico dos alunos em busca da construção do conhecimento químico.

A experimentação é um recurso pedagógico que contempla diversas habilidades, principalmente as cognitivas, mas muitos professores ainda as utilizam de maneira inadequada, desvalorizando seus aspectos cognitivos e privilegiando muitas vezes somente seu caráter motivador. Nas pesquisas, percebe-se que o professor faz pouco uso do laboratório didático no processo de ensino-aprendizagem (LIMA, 2004), e quando o faz é de maneira acrítica, limitando-se a manipular materiais e desenvolver experimentos de demonstração e comprovação de teoria.

Para Hodson (1990), muitos professores utilizam o laboratório experimental sem uma adequada reflexão, acreditando que o experimento possa ensinar aos estudantes sobre o que é a ciência e sua metodologia. Esta visão parece não reconhecer o potencial da experimentação no ensino de química, uma vez que esta atividade pode contribuir para o desenvolvimento conceitual e cognitivo dos alunos.

Alguns professores utilizam o trabalho prático com o objetivo de solucionar os problemas de aprendizagem, e muito do que poderia ser substancial para 0 desenvolvimento e evolução conceitual do aluno é muitas vezes ignorado. Muitas vezes, o professor está preocupado com o produto e não com o processo, enfatizando os resultados 
e desmerecendo os processos de coleta e análise dos dados. Segundo Amaral e Silva ${ }^{5}$ (1999 apud ZANON; SILVA 2000), muitos professores imaginam ser possível "comprovar a teoria no laboratório" ou que os alunos consigam por si só obter uma teoria a partir de experimentos "por descoberta".

As pesquisas têm demonstrado que quando a atividade é desenvolvida de forma acrítica e aproblemática, ou seja, quando o aluno não está envolvido em um problema e suas possíveis soluções, pouco contribui ao processo de ensino e aprendizagem. Watson (1995), em uma pesquisa realizada com alunos da Espanha e Inglaterra sobre a compreensão das reações de combustão, verificou que a maior quantidade de aulas práticas oferecidas para alunos ingleses em relação aos alunos espanhóis, não foi suficiente para alterar as concepções que os alunos tinham antes da aula experimental. Muitos estudantes falharam ao desenvolver um modelo de explicação que se assemelhasse ao científico. A diferença existente entre os estudantes dos dois países revelou-se nos exemplos que os alunos ingleses citaram para explicar a combustão, que são encontrados facilmente no cotidiano.Talvez, uma das causas do não entendimento conceitual é a falta de discussão de modelos explanatórios unidos ao trabalho prático.

O autor declara que para o trabalho prático tornar-se eficaz na reconstrução da teoria pelo estudante, este precisa gastar mais tempo interagindo com suas idéias e menos tempo interagindo com aparatos. Ou seja, executar atividades experimentais que não privilegiam momentos de discussão, análise dos dados, elaboração de hipóteses, evidenciando somente o experimento em si, não contribui significativamente para o desenvolvimento de habilidades cognitivas pelos alunos.

Desta forma, torna-se evidente a necessidade de desenvolver e executar atividades experimentais que contribuam para um melhor entendimento dos processos científicos, dando a oportunidade aos alunos se envolverem em um problema e procurar suas possíveis soluções com o auxílio do professor.

As aulas experimentais planejadas para promover a aprendizagem significativa do aluno envolvem, segundo os Parâmetros Curriculares Nacionais (BRASIL,1999, p. 37):

[...] considerar o desenvolvimento de habilidades cognitivas, tais como controle de variáveis, tradução da informação de uma forma de comunicação para outra como gráficos, tabelas, equações químicas, a elaboração de estratégias para a resolução de problemas, tomadas de decisão baseadas em análises de dados e valores, como integridade na comunicação dos dados, respeito às idéias dos colegas e às suas próprias e colaboração no trabalho coletivo.

\footnotetext{
${ }^{5}$ AMARAL, L.O.F; SILVA, A.C. Trabalho Prático: Concepções de professores sobre as Aulas Experimentais de Química Geral. Manuscrito (monografia), Belo Horizonte, Departamento de Química, Universidade Federal de Minas Gerais, 1999.
} 
Assim, as atividades experimentais para serem significativas no processo de aprendizagem devem conter ação e reflexão. Não basta apenas que os alunos realizem o experimento, é necessário integrar a prática com discussão, análise dos dados obtidos e interpretação dos resultados, fazendo com que o aluno investigue o problema. Por atividade prática pode-se entender qualquer trabalho em que os alunos estejam ativos e não passivos, ressalta Rosito (2003).

Hodson, em diversos artigos, discute as cinco principais razões pela qual os professores alegam utilizar as atividades experimentais com seus alunos: (1) para motivar, estimulando o interesse; (2) para ensinar habilidades de laboratório; (3) para aumentar a aprendizagem de conceitos científicos; (4) para promover a introdução ao método científico e desenvolver o raciocínio através de sua utilização; (5) para desenvolver certas "atitudes científicas". Mas, o que as pesquisas evidenciam é que o trabalho prático nem sempre promove 0 que os professores esperam desenvolver em seus alunos com a experimentação, como por exemplo: a motivação, os ganhos na aprendizagem, as habilidades e as atitudes (HODSON, 2005). Alguns desses objetivos também podem ser encontrados nas falas de professores brasileiros. Em pesquisa realizada por Lima (2004), as principais justificativas dadas por eles para a utilização das atividades experimentais são: para despertar a curiosidade, motivar, concretizar o que foi discutido em aula e despertar o interesse pela química.

Porém, Hodson (1994), alerta para alguns cuidados que devem ser tomados em relação os objetivos citados:

Motivação: enquanto muitos alunos desfrutam das atividades experimentais e desenvolvem habilidades positivas acerca da ciência, uma importante minoria expressa aversão ao trabalho prático. Os estudantes parecem valorizar o desafio cognitivo, porém o trabalho não precisa ser tão difícil que não se possa compreendêlo, mas é preciso que haja um objetivo claro e que funcione. Freqüentemente, entretanto, o que constatamos nas atividades práticas realizadas nas escolas são propostas que privilegiam a coleta de dados e com o objetivo pré-determinado, tirando o caráter motivador e cognitivo da atividade;

Aquisição de habilidades: esses argumentos apresentam-se em duas categorias: uma em termos de aquisição de um conjunto de habilidades gerais e generalizáveis e esquemas capazes de serem transferidos, e outra em termos do desenvolvimento de esquemas básicos considerados essenciais para os futuros cientistas e técnicos. A 
aquisição de técnicas ou destrezas de laboratório tem pouco valor em si mesma. Caso um experimento exija uma habilidade na qual o aluno não venha a utilizar novamente, deve-se procurar procedimentos alternativos como demonstração pelo professor ou pelo computador. É preciso que o professor seja mais crítico sobre quais são as habilidades que se quer ensinar, e assegurar aos alunos que a carência de determinadas habilidades não constitui uma barreira adicional para a aprendizagem.

Há evidências de que, dependendo do tipo do experimento, pode não haver aquisição de habilidades. O trabalho prático não é necessário no sentido de prover os estudantes de certas habilidades de laboratório, mas certas habilidades são necessárias se pretende-se engajar os estudantes em atividades práticas;

Aprendizagem do conhecimento científico e aprendizagem dos métodos científicos: evidências empíricas concernentes à eficácia do trabalho prático como uma forma de aprender o conhecimento científico são difíceis de serem interpretadas e apresentam-se inconclusivas. O autor cita resultados de um trabalho realizado por Moreira ${ }^{6}$ com alunos britânicos, no qual estes freqüentemente realizam experimentos com uma idéia muito vaga do que estão fazendo, não compreendendo o propósito do experimento ou as razões para a escolha de tal procedimento, e com uma pequena compreensão dos conceitos a ele relacionados. Os alunos podem adquirir uma imagem distorcida e inadequada da ciência e projetar uma visão de que os cientistas sabem antecipadamente os resultados dos experimentos executados;

Atitudes Científicas: podem ser definidas como aquelas abordagens e atitudes relacionadas a informações, procedimentos e idéias consideradas essenciais para aqueles que lidam com a ciência. $O$ distanciamento da vida real projetada pela idéia estereotipada das atividades científicas não é bem recebida pelos alunos. Poucos deles se sentem estimulados a agir de maneira científica nos laboratórios das escolas, pois associam a imagem de cientista a um investigador objetivo e livre de valores e preconceitos, tendo a necessidade de perceber que os cientistas podem ser afetuosos, sensíveis, ou ainda que, pessoas afetuosas, sensíveis e bem humoradas possam vir a ser cientistas.

As observações de Hodson evidenciam que muitas atividades práticas são elaboradas e executadas de forma a não explorar as potencialidades do trabalho prático

\footnotetext{
${ }^{6}$ Para maiores informações consultar HODSON (1990, p. 36)
} 
como a análise dos dados, a elaboração de hipóteses, a discussão em grupos, entre outras habilidades cognitivas que a experimentação pode desenvolver.

Hodson (1994) sugere 3 aspectos para a prática pedagógica alcançar resultados mais positivos com relação à aprendizagem dos alunos:

1. a aprendizagem das ciências: como a aquisição e o desenvolvimento de conhecimentos teóricos (conteúdos das ciências);

2. a aprendizagem sobre a natureza das ciências: o desenvolvimento da natureza e dos métodos da ciência, tomando consciência das interações complexas entre ciência e sociedade;

3. a prática da ciência: desenvolvimento dos conhecimentos técnicos sobre a investigação científica e a resolução de problemas.

Se um dos objetivos do Ensino de Ciências é a aprendizagem de conceitos, a participação do aluno na construção de suas próprias idéias torna-se essencial. É necessário dar aos alunos a oportunidade de compreender e avaliar as teorias e oferecer estímulos adequados para o desenvolvimento conceitual. Hodson (1994, p. 305), sugere 4 passos:

1. identificar as idéias e concepções dos alunos;

2. elaborar experiências para explorar tais idéias e concepções;

3. oferecer estímulos para que desenvolvam e possivelmente modifiquem suas idéias e concepções;

4. apoiar as tentativas de repensar e reelaborar estas idéias e concepções.

Desta forma, os alunos estariam colocando em prova suas idéias e suas predições, contribuindo significativamente para o desenvolvimento conceitual.

Em uma revisão sobre a aprendizagem em laboratório, Johnstone e Al-Shuali (2001), destacam que as principais metas apontadas pelos professores para a utilização da experimentação são: encorajar os alunos em observações, desenvolver habilidades manipulativas, treinar a resolução de problema, verificar fatos e princípios já ensinados, tornar o fenômeno mais real através da experiência, entre outros 120 objetivos catalogados por Kirschner e Meester, citados em seu artigo.

Os autores alertam para alguns cuidados que devem ser tomados em relação a essas metas. Argumentam que os dados observacionais só podem ocorrer com uma estrutura teórica, uma vez que o que é importante nas ciências são as idéias que se têm sobre os dados, ao invés dos dados em si mesmo. Seria um erro, segundo os autores, não 
considerar a relação entre a observação e o entendimento, uma vez que o observador pode não estar neutro no processo de coleta e análise e interferir nos resultados com idéias existentes em sua mente.

Desta maneira, muito mais do que somente observar ou permanecer passivo em uma atividade experimental, o aluno, com o auxílio do professor, pode localizar o problema, identificar as variáveis e elaborar hipóteses que estejam de acordo com os conceitos químicos aprendidos ou em construção com o auxílio das atividades experimentais.

Caamaño (2005), define diferentes funções do trabalho prático experimental na química:

1. contribuir para a evidência experimental na aprendizagem dos conceitos (função ilustrativa dos conceitos);

2. interpretar fenômenos e experiências a partir de modelos conceituais (função interpretativa da experiência);

3. aprender o uso instrumental e das técnicas básicas de laboratório (função da aprendizagem de métodos e técnicas de laboratório);

4. desenvolver métodos para resolver perguntas teóricas em relação à construção de modelos (função investigativa relacionada com a resolução de problemas teóricos e construção de modelos);

5. desenvolver e aplicar métodos para resolver questões do tipo prático contextualizadas em âmbitos da química cotidiana e da química aplicada (função investigativa com resolução de problemas práticos).

A autora descreve cinco aspectos que, para ela, deveriam estar presentes ao se planejar e executar as atividades experimentais. Argumenta na defesa de experimentos que permitam, além de desenvolver técnicas de laboratório, essenciais para aqueles que seguirão carreiras científicas, a resolução de problemas que possam auxiliar a construção de conceitos químicos e que possam ser integrados com o cotidiano, contribuindo para o desenvolvimento conceitual e cidadão.

Em uma recente revisão sobre as atividades experimentais, Hofstein e Lunetta (2004) definem as atividades de laboratório como aprendizagem de experiências na qual os estudantes interagem com materiais ou com modelos para observar e entender o mundo natural. Ainda, os autores afirmam que o laboratório de ciências é um ambiente de aprendizagem onde os estudantes desenvolvem seus entendimentos sobre os conceitos científicos, sobre as habilidades investigativas científicas, e percepções sobre a ciência; ambiente onde os alunos podem trabalhar cooperativamente em pequenos grupos a fim de 
investigar um fenômeno científico, podendo aumentar as relações sociais assim como atitudes positivas e crescimento cognitivo.

Ao analisar os diferentes objetivos que cada autor atribui às atividades experimentais, fica evidente que o interesse ao abordar tal estratégia ultrapassa a concepção da experimentação pela experimentação, ou seja, de utilizar esta estratégia como fio condutor para uma aula mais agradável ou estimulante, sem muitos aprofundamentos conceituais e com pouca ou nenhuma relação da teoria com a prática. Pelo contrário, o interesse agora centraliza os objetivos conceituais e cognitivos, dando a oportunidade aos alunos de evidenciar fenômenos e (re) construir suas idéias. O papel do aluno já não é mais somente de espectador; o professor incentiva sua participação ativa nas etapas de investigação.

Os experimentos investigativos são apresentados como uma maneira de privilegiar a participação do aluno na construção do conhecimento.

Neste trabalho, considera-se atividade experimental investigativa como aquelas atividades nas quais os alunos não são meros expectadores e receptores de conceitos, teorias e soluções prontas. Pelo contrário, os alunos participam da resolução de um problema proposto pelo professor ou por eles mesmos; elaboram hipóteses; coletam dados e os analisam; elaboram conclusões e comunicam os seus resultados com os colegas. O professor se torna um questionador, conduzindo perguntas e propondo desafios aos alunos para que estes possam levantar suas próprias hipóteses e propor possíveis soluções para o problema.

Assim, estas atividades podem ser desenvolvidas pelos professores através de demonstrações experimentais investigativas ou, então, realizadas pelos próprios alunos, mas sempre priorizando a participação dos estudantes na solução do problema.

Entretanto, muitas definições são encontradas na literatura para o termo investigação ou atividades investigativas, havendo a necessidade de uma breve revisão dos pressupostos epistemológicos que fundamentam essa abordagem, para que assim possamos avaliar as suas potencialidades ou deficiências no processo de ensino e aprendizagem 


\subsection{Algumas concepções que orientam as atividades experimentais}

Diversas concepções orientam o planejamento e desenvolvimento das atividades experimentais no ensino de química e de ciências.

A experimentação pode ser desenvolvida por diferentes perspectivas: demonstrativa, empirista-indutivista, dedutivista-racionalista ou construtivista (MORAES, 1998). A experimentação demonstrativa propõe atividades práticas voltadas às demonstrações de verdades estabelecidas, não permitindo compreender sua construção, e encontra-se implícita a idéia da ciência infalível. Na visão empirista-indutivista, as atividades práticas procuram derivar generalizações indo do particular ao geral. O conhecimento científico é obtido daquilo que se observa. Esta visão desvaloriza o papel do trabalho científico, caracterizando-o como conjunto de verdades definitivas. Num experimento dedutivista-racionalista as atividades práticas são orientadas por hipóteses derivadas da teoria. A observação está impregnada de pressupostos teóricos.

$\mathrm{Na}$ perspectiva construtivista, as atividades são organizadas considerando as concepções prévias dos alunos. Os experimentos são desenvolvidos na forma de problemas ou testagem de hipóteses, envolvendo, se necessário, o cotidiano do aluno. A postura construtivista aceita que nenhum conhecimento é assimilado do nada, mas deve ser reconstruído pela estrutura de conceitos já existentes.

Hofstein e Lunetta (2004), ao investigarem as concepções construtivistas presentes na literatura, verificam que para alguns autores esse processo é ativo, interpretativo e interativo, onde a aprendizagem é contextualizada e os aprendizes constroem seu conhecimento resolvendo problemas significativos ou genuínos. Assim, os autores defendem que o laboratório na escola pode contribuir para tais oportunidades se as expectativas do professor permitirem que os alunos se engajem intelectualmente em experiências investigativas significativas nas quais possam construir conceitos científicos com os outros aprendizes em sala.

Ao descrever o construtivismo, Shiland (1999) argumenta que a essência do construtivismo está no conhecimento construído na mente do aprendiz e que idéias alternativas trazidas pelos alunos à sala de aula podem dificultar a aprendizagem. $\mathrm{O}$ autor amplia suas idéias argumentando que para a aprendizagem significativa ocorrer são necessários um contexto social, uma certa insatisfação do aluno com o conhecimento atual e que o novo conhecimento seja aplicável e útil para os alunos. 
Todas estas proposições teriam, segundo o autor, implicações diretas no trabalho laboratorial, devendo haver, por parte do professor, uma mudança na estruturação e objetivos dessas atividades de forma a aumentar e valorizar as atividades cognitivas, como, por exemplo, permitir que os alunos identifiquem e controlem variáveis ou que participem da elaboração do procedimento experimental. Direcionar as atividades laboratoriais para o início da aula pode contribuir para o professor diagnosticar as concepções alternativas dos estudantes, possibilitando também, aos alunos predizerem e elaborarem hipóteses para os resultados.

Ainda avaliando as implicações do construtivismo para as atividades laboratoriais, Shiland (1999) argumenta que, ao elaborar atividades nas quais os resultados não são óbvios e são aplicáveis, os alunos poderão se sentir insatisfeitos com suas concepções e desafiados a solucionar o problema usando suas novas idéias em contextos mais amplos. Contribuindo para este ambiente de aprendizagem significativa, o professor poderia elaborar atividades para os estudantes trabalharem em grupos, discutindo suas predições e resultados com toda a classe, valorizando assim as habilidades e competências sociais que a atividade laboratorial pode desenvolver.

Tamir (1977) distingue dois tipos de trabalho experimental: os de verificação e os de investigação. No primeiro caso é o professor que identifica o problema, que relaciona o trabalho com outros anteriores, que conduz as demonstrações (fora de um contexto de problematização) e dá instruções diretas - tipo receita. O segundo tipo de trabalho experimental, o investigativo, apresenta as seguintes características: (1) deve ser um meio para explorar as idéias dos alunos e desenvolver a sua compreensão conceptual; (2) deve ser sustentado por uma base teórica prévia informadora e orientadora da análise dos resultados (3) deve ser delineado pelos alunos, para possibilitar um maior controle sobre sua própria aprendizagem, sobre as suas dificuldades e de refletir sobre o porquê dessas atividades, para as ultrapassar.

Mas, ao revisar a literatura, muitas abordagens investigativas são encontradas. Algumas tratadas como uma cópia da investigação científica, outras mais sutis, mas que exploram os aspectos positivos que uma investigação pode trazer para o desenvolvimento cognitivo do aluno.

A proposta investigativa elaborada por Gil-Pérez e Valdés Castro (1996), utiliza a metáfora de investigadores novatos, na qual a atividade de investigação 
realizada pelo novato, ou seja, o aluno, é conhecida pelo "expert" que dirige o trabalho, neste caso o professor, contanto que esta réplica do trabalho científico não se dirija a reducionismos e deformações apresentadas por alguns professores com relação ao processo científico.

Ainda, segundo Gil-Pérez e Valdés Castro (1996, p.156):

Desde este ponto de vista, uma prática de laboratório que pretenda aproximar-se a uma investigação tem que deixar de ser um trabalho exclusivamente experimental e integrar muitos outros aspectos da atividade científica igualmente essenciais .

Assim os autores sugerem dez pontos fundamentais para a realização e efetividade da atividade experimental como investigação dirigida:

1. Apresentar situações problemáticas.

2. Favorecer a reflexão dos estudantes sobre a relevância e o possível interesse das situações propostas.

3. Potencializar análises qualitativas, significativas que ajudem a compreender e acatar as situações planejadas e a formular perguntas operativas sobre o que se busca.

4. Considerar a elaboração de hipóteses como atividade central de investigação científica, sendo este processo capaz de orientar o tratamento das situações e de fazer explícitas as pré-concepções dos estudantes.

5. Considerar as análises, com atenção para os resultados (interpretação física, confiabilidade) a partir dos conhecimentos disponíveis, das hipóteses manejadas e dos resultados das demais equipes de estudantes.

6. Análise detalhada dos resultados.

7. Considerar possíveis perspectivas do estudo com outros níveis de complexidade, relacionando possíveis aplicações e repercussões negativas.

8. Esforços de integração do estudo realizado com outros campos do conhecimento.

9. Conceder uma importância especial a memória científica que reflita o trabalho realizado e possa ressaltar o papel da comunicação e do debate na atividade científica

10. Ressaltar a dimensão coletiva do trabalho científico, por intermédio de grupos de trabalho, que interajam entre si.

Os autores defendem que as práticas devem passar de mera ilustração a atividades de investigação orientada capazes de resgatar o trabalho científico, propondo evitar as visões simplistas e deformadas da atividade científica, partindo de atividades baseadas em investigações bem conhecidas pelo professor, que se torna o mediador do processo. Os dez pontos propostos não precisam e não devem ser seguidos à risca, são indicações para um trabalho experimental mais rico, que contribua para o desenvolvimento de habilidades cognitivas, através do questionamento, levantamento de hipótese, refutação ou confirmação dessas 
hipóteses, análise dos dados, conclusões, comunicação dos resultados obtidos, ultrapassando a passividade das atividades que somente exploram habilidades manipulativas e comprovação de teorias já vistas em sala de aula pelos alunos. GilPérez e colaboradores (2005, p.313) também atentam para a má interpretação de sua proposta, se comparada com a desacreditada proposta de "aprendizagem por descoberta":

É preciso sublinhar que agora não se concebe aos alunos e alunas como investigadores autônomos trabalhando na fronteira do conhecimento. Esta metáfora (que foi proposta como reação ao que concebia os estudantes como simples receptores) apresenta graves limitações e não resulta útil para organizar o trabalho dos alunos. Uma metáfora que concebe aos estudantes como investigadores novatos (que estruturados em equipe cooperativas, abordam situações problemáticas de interesse, interagindo com as outras equipes e com o resto da comunidade científica, representada pelo professor e por textos) permite, na nossa opinião, uma melhor compreensão da situação de aprendizagem escolar.

Os dez aspectos apontados pelos autores revelam objetivos pedagógicos essenciais para a participação ativa do aluno na construção do conhecimento, como habilidades de questionamento, levantamento de hipótese, análise de dados, habilidades cognitivas essenciais para o desenvolvimento conceitual e crítico do aluno.

Aproximar os alunos do trabalho científico pode contribuir para que estes não construam em suas mentes um "método científico" fechado e rígido, como muitas vezes apresenta-se nos livros, reforçando várias concepções errôneas da ciência, mas ao mesmo tempo, é preciso estar atento em não querer transformar a atividade experimental em uma pesquisa científica, uma vez que os alunos muitas vezes ainda não estão preparados para compreender o propósito do experimento ou as razões para a escolha de tal procedimento, devido, em parte, a uma pequena compreensão dos conceitos a ele relacionados (HODSON, 1994).

Quanto a problematização sugerida por Gil-Pérez et al. (2005), algumas considerações podem ser feitas. As atividades experimentais desenvolvidas com o objetivo de proporcionar momentos de discussão, questionamento, diálogo, devem estar acompanhadas de situações problematizadoras para serem consideradas uma atividade de investigação, não limitando a ação do aluno à manipulação ou observação (CARVALHO et al., 1999). Mas, ao mesmo tempo, alguns julgamentos precisam ser realizados quando nos referimos a situações problemáticas abertas. Os problemas abertos podem ser considerados, para alguns autores, como aqueles problemas onde não existem 
procedimento automático ou que possam ser solucionados de forma algorítmica, requerendo um processo de reflexão ou tomada de decisões para a sua resolução (ECHEVERRÍA; POZO, 1998). Os exercícios por sua vez, envolvem a aplicação direta de uma fórmula ou algoritmo. Ainda, segundo Gil-Pérez e Valdés Castro (1996), para facilitar o engajamento dos estudantes na tarefa proposta, as atividades como processo investigativo devem ser problemas abertos e de nível de dificuldade adequado, capazes de favorecer a reflexão dos estudantes sobre sua relevância. Assim, a situação problema não pode ter resolução tão evidente, mas também não pode ser tão difícil, devendo respeitar a zona de desenvolvimento proximal ${ }^{7}$ do aluno. Segundo os autores, o professor precisa preparar a atividade de forma a enfrentar as situações imprevistas e o aluno precisa estar disposto e sentir a necessidade em tomar atitudes e decisões.

Entretanto, alguns obstáculos podem ser encontrados ao se introduzir problemas muito abertos; primeiro, devido a certa imaturidade dos alunos para interpretar o que é um problema, como descreve Laburú (2003), em uma análise crítica da proposta de Gil-Pérez e colaboradores, afirmando que, foi verificada entre os alunos pesquisados por ele, enorme dificuldade em entender o problema aberto colocado devido principalmente à incompreensão de alguns termos para a interpretação do problema. Outra consideração a se fazer está no fato de que o que é problema para alguns alunos, pode não ser para outros (ZYLBERSZTAJN, 1998); assim, enquanto alguns alunos se engajam no problema e são desafiados a solucioná-lo, outros apresentam maior habilidade ou conceitos para resolvê-lo, ou até mesmo já criaram alguns modelos implícitos para sua resolução. Também, uma situação pode não ser problemática para o professor mas ser para o aluno, ou vice-versa. Outro obstáculo para a utilização dos problemas abertos pode ser atribuído a algumas dificuldades metodológicas encontradas pelos professores (LIMA, 2004) e ao número reduzido de aulas para sua execução.

Com relação à abordagem defendida por Gil-Pérez e colaboradores, deve-se considerar ainda que, a realidade das escolas brasileiras, caracterizada pela falta de recursos e pouco investimento no preparo dos professores, dificultaria ou mesmo inviabilizaria a implementação de tal abordagem, que se apresenta de forma muito aberta,

\footnotetext{
${ }^{7}$ ZDP corresponde à distância entre o nível de desenvolvimento cognitivo real do indivíduo, tal como poderia ser sua capacidade de resolver um problema sozinho, e seu nível de desenvolvimento potencial, que seria medido por sua capacidade de resolver problemas sob a orientação ou colaboração com companheiros mais capazes. (VYGOTSKY,1998).
} 
responsabilizando demasiadamente as atitudes e ações dos alunos. A intervenção do professor precisa ser muito mais direta e freqüente do que a esta metodologia propõe, uma vez que, grande parte dos estudantes do ensino médio apresenta carência conceitual e procedimental. O papel do professor é de fundamental importância para auxiliar os estudantes no entendimento do problema, elaboração de hipóteses, na manipulação dos equipamentos, análise dos dados e conclusões; portanto ao analisar esta metodologia verifica-se que algumas etapas são muito mais complexas e exigem muito mais cautela do que explicitam os autores.

Com relação às abordagens de atividade experimental, Domin (1999a) destaca quatro estilos de experimentação que podem envolver a participação do aluno em diferentes níveis. O estilo expositivo ou também conhecido como de verificação ou tradicional, é aquele no qual o aluno faz o que o professor determina, guiado por um roteiro tipo receita. Este estilo apresenta uma abordagem dedutiva e os resultados são prédeterminados pelo professor. Este estilo é caracterizado por minimizar recursos, tempo e equipamentos, porém pouca demanda cognitiva é exigida do aluno. O autor relata que práticas do tipo expositivas não priorizam a interpretação dos dados coletados.

O estilo investigativo requer que o estudante formule o problema, relate a investigação previamente, crie hipóteses, prediga o resultado e execute a investigação. $O$ estilo descoberta (investigação guiada), difere do estilo investigativo no que diz respeito ao procedimento que é dado pelo professor e os resultados que são conhecidos por ambos. Porém, alguns autores criticam este estilo, atribuindo a impossibilidade de o aluno descobrir algo que não está preparado para descobrir (HODSON, 1996 apud DOMIN, 1999a) ${ }^{8}$ e que, algumas vezes, o professor não pode esperar que um grupo de alunos descubra o mesmo princípio, o mais provável é que um aluno passe a resposta do problema para o outro. Por fim, o estilo baseado em problemas é aquele no qual o estudante desenvolve o procedimento e o resultado é desconhecido por ele. O papel do professor é direcionar os estudantes para a resolução do problema e os alunos devem elaborar hipóteses para a sua conclusão, ou seja, há a necessidade de pensar sobre o que estão fazendo e para que estão fazendo. As características de cada estilo, segundo Domin (1999a), podem ser demonstradas conforme a tabela 1.1 a seguir:

\footnotetext{
${ }^{8}$ Hodson, D. Journal of Curriculum Studies, 28, p. 115-130, 1996.
} 
Tabela 1.1- Estilos de atividades de laboratório propostos por Domin

\begin{tabular}{|c|c|c|c|}
\hline Estilo & Resultado & Abordagem & Procedimento \\
\hline Exposição & Pré-determinado & Dedutivo & Dado \\
\hline Investigação & Indeterminado & Indutivo & Estudante desenvolve \\
\hline Descoberta & Pré-determinado & Indutivo & Dado \\
\hline Baseado em problema & Indeterminado & Dedutivo & Estudante desenvolve \\
\hline
\end{tabular}

Com relação a essa taxonomia, Jhonstone e Al-Shuali (2001), tecem alguns comentários em uma revisão sobre estilos de experimentos de laboratório. Os autores argumentam que alguns estudantes observam dados irrelevantes e desprezam outros que são importantes. Assim, atividades pré-laboratório seriam importantes antes de executar o experimento para que os alunos não gastem um tempo demasiado em manipulação sem alcançar a aprendizagem de conceitos.

Com relação ao termo investigação (inquiry), Hofstein e Lunetta (2004), argumentam que este se refere à aprendizagem de ciências, em sala de aula ou laboratórios, em que os estudantes e seus professores exploram e discutem a ciência em um contexto de "narrativa de investigação". Mas, ao mesmo tempo, os autores alertam para os cuidados que devem ser tomados quando se pretende adotar esta abordagem, argumentando que somente o laboratório de investigação não é suficiente para permitir aos estudantes construir complexos entendimentos conceituais, sendo necessário a intervenção e negociação de uma autoridade, no caso, o professor.

Em um artigo ainda mais recente, Hofstein e colaboradores (2005), concebem as atividades investigativas (inquiry-type laboratories) centrais para a aprendizagem de ciências desde que os estudantes estejam envolvidos no processo de compreensão de problemas e questões científicas, formulação de hipóteses, planejamento de experimentos, coleta e análise de dados e aptos a inferir conclusões sobre os problemas científicos ou fenômenos.

Segundo "The National Science Education Standards", descrito no artigo de Hofstein e Lunetta (2004), o termo investigação (inquiry) pode ser definido de duas maneiras: (a) como capacidade de entendimento, na qual os estudantes têm a oportunidade de construir conceitos e padrões, e criar significado sobre uma idéia para explicar suas experiências; (b) em termos de habilidades e competências. Bybee ${ }^{10}$, citado ainda por Hofstein e Lunetta (2004), inclui para o termo identificar e propor questões cientificamente orientadas, formular

\footnotetext{
${ }^{9}$ Grifo dos autores

${ }^{10}$ BYBEE, R. (2000). Teaching science as inquiry. Em: J. Minstrel e E. H. Van Zee (Ed), Inquiring into inquiry learning and teaching (pp. 20-46). Washington, D.C: American Association for the Advanced of Science.
} 
hipóteses, planejar e conduzir investigações científicas, formular e revisar explicações científicas, e comunicar e defender os argumentos científicos. $\mathrm{O}$ autor argumenta ainda que muitas destas habilidades e competências estão de acordo com aquelas que caracterizam o trabalho laboratorial investigativo, ou seja, uma atividade que coloca o estudante no centro do processo de aprendizagem.

Ainda com relação às diferentes classificações dadas por autores para as atividades experimentais investigativas, Caamaño (2004), partindo das idéias de Woolnough e Alsop e, ainda, Gott e Duggan, citados em seu artigo, classifica os trabalhos práticos da seguinte maneira:

- Experiências: conhecimentos perceptivos dos fenômenos (experiências perceptivas e interpretativas);

- Experimentos ilustrativos: utilizados para evidenciar experimentalmente a formação de determinados conceitos, e ilustração de leis e princípios, promovendo a curiosidade pelo o que correrá previamente a sua realização.;

- Exercícios práticos: utilizados para aprender determinadas habilidades práticas e processos e para comprovar experimentalmente relações entre variáveis já conhecidas em nível teórico;

- Investigações: servem para aprender a planejar e desenvolver pequenas investigações no decurso da resolução de problemas teóricos (investigações para resolver problemas teóricos para a formação de modelos científicos) ou de problemas práticos (investigações para resolver problemas práticos, como problemas delineados no contexto da vida cotidiana ou de aplicações práticas das ciências).

$\mathrm{Na}$ abordagem investigativa defendida pela autora, o planejamento das atividades experimentais ocorre través das seguintes fases:

1. estabelecimento e percepção do problema, na qual o professor planeja e contextualiza o problema a resolver, e os estudantes precisam compreendê-lo e conceituá-lo;

2. planejamento, em que deve decidir o método que se pode utilizar e planejar o procedimento experimental e os cálculos que serão necessários realizar, bastando dispor de uma visão global da investigação (proposição de uma seqüência de questões estruturadas para guiar o diálogo professor- aluno); 
3. realização, que implica na montagem experimental, da tomada de dados e os tratamentos numéricos, gráficos ou informáticos dos dados;

4. avaliação, que implica avaliar os resultados obtidos e a análise de sua plausibilidade comparando com os resultados obtidos por outros grupos e com valores já determinados;

5. comunicação, que implica a redação de um informe e sempre que possível, a comunicação oral da investigação realizada.

As etapas propostas pela autora são condizentes com a abordagem investigativa, uma vez que os alunos participam de todas as etapas de investigação. Entretanto, é importante salientar a importância dada à mediação do professor no planejamento e contextualização do problema, uma vez que os alunos podem não estar preparados para propor e compreender um problema; mas nas outras etapas, não foi mencionada a importância dessa mediação.

Uma outra definição para as investigações científicas é elaborada por Moraes (1993). Para o autor" : "Um verdadeiro experimento é aquele que permite ao aluno decidir como proceder nas investigações, que variáveis manipular, que medidas realizar, como analisar e explorar os dados obtidos e como organizar seus relatórios" (MORAES,1993, apud ROSITO, 2003, p.203). A experimentação deve questionar o aluno, não trazer somente soluções prontas.

Neste sentido o autor destaca alguns elementos que devem ser levados em conta no processo de investigação científica:

- uma fase inicial, na qual os problemas são expostos e discutidos; as hipóteses para a resolução são formuladas e os procedimentos instrumentais selecionados;

- uma fase de desenvolvimento, em que os experimentos são realizados para coleta de dados;

- uma fase de busca de referencial teórico e de reflexão, na qual se analisam e interpretam os dados coletados;

-uma fase de elaboração de um relatório, na qual se registram as atividades desenvolvidas juntamente com a análise e interpretação dos resultados obtidos.

$O$ autor argumenta que as fases podem ser estruturadas conforme o objetivo do professor, destacando que uma investigação não ocorre rigorosamente em

\footnotetext{
${ }^{11}$ MORAES, R. Experimentação no ensino de Ciências. Projeto Melhoria da Qualidade de Ensino- Ciências $1^{0}$ Grau. Governo do Estado do Rio Grande do Sul - SE, 1993.
} 
etapas, podendo ser um processo flexível, de ir e vir, que vai gradativamente do problema á procura da solução.

As abordagens discutidas até aqui têm muitos pontos em comum, principalmente em relação aos objetivos pretendidos. Todas essas abordagens têm como meta alcançar a aprendizagem do aluno e torná-lo ativo no processo de construção do conhecimento, dando-lhes a oportunidade de pensar sobre um problema proposto, questionar, elaborar hipóteses para sua conclusão, analisar os dados com os seus pares, interagir com os colegas trocando idéias e concepções, comunicar os dados com os colegas e professor.

Desta forma, se pretendemos que as atividades experimentais possam alcançar alguns desses objetivos, elas precisam estar envolvidas em um contexto que permita que tais metas sejam atingidas. As atividades experimentais investigativas neste contexto, são atividades nas quais os alunos participam ativamente da construção do conhecimento químico, questionando o professor, mesmo se esta atividade for desenvolvida fora do ambiente laboratorial, ou realizada pelo professor.

Um outro ponto a questionar está relacionado ao procedimento a ser elaborado pelos alunos. O aluno muitas vezes não tem o preparo conceitual e manipulativo para elaborar alguns experimentos, porém, com o auxílio do professor, esta etapa pode ser alcançada. Mas, é preciso estar atento ao tempo que este tipo de atividade pode consumir, uma vez que as aulas de química nas escolas brasileiras são reduzidas, por isso, realizar todas as atividades nesta abordagem seria inviável.

Entretanto, as atividades experimentais realizadas pelo professor em sala de aula podem também ser planejadas com o objetivo de desenvolver habilidades de elaboração de hipóteses, análise dos dados e questionamentos. Cabe ao professor criar um ambiente onde o aluno participe ativamente do processo de construção do conhecimento químico.

Os experimentos de laboratório mesmo quando desenvolvidas por demonstração, devem ser planejados a fim de que os alunos expressem suas idéias na busca de explicações para os fenômenos apresentados; organizando, testando e argumentando sobre os dados coletados, com a possibilidade da construção de modelos condizentes com os científicos. Para isso, o professor deve tornar-se orientador na sala de aula e propor questões elicitativas a fim de conduzir seus alunos para a resolução do problema apresentado.

Deve-se distinguir, entretanto, as atividades investigativas feitas por demonstração e as atividades de demonstração. Conforme aponta Carvalho et al. (1999), as atividades de demonstrações têm o único objetivo de ilustrar o que foi falado, de comprovar um conteúdo 
já ensinado, ou seja, mostrar, aos alunos, que o professor estava certo. Já as atividades de caráter investigativo, buscam uma questão problematizadora que ao mesmo tempo desperte a curiosidade e oriente a visão do aluno sobre as variáveis relevantes do fenômeno a ser estudado, fazendo com que eles levantem suas próprias hipóteses e proponham possíveis soluções. Para Carvalho et al. (1999, p.41):

As chamadas demonstrações experimentais investigativas são demonstrações que partem da apresentação de um problema sobre o fenômeno a ser estudado e da investigação a respeito deste fenômeno. Neste contexto, percebemos mudanças significativas no que se refere ao papel do professor e do aluno: o professor torna-se um orientador em sala de aula, tentando conduzir seus alunos, pela argumentação e pela proposição de questões, ao levantamento de hipóteses acerca da atividade experimental apresentada, com o objetivo de levar estes alunos a procurar possíveis explicações causais para o fenômeno observado, ou seja, serem ativos no processo de construção do conhecimento.

O que se considera aqui, como atividades experimentais investigativas, são atividades que contribuam para o desenvolvimento cognitivo do aluno. As atividades não precisam ser realizadas da forma como defendida por Gil-Pérez et al. (2005), por exemplo, na qual o aluno precisa enfrentar um problema aberto e executar experimentos no laboratório para coleta de dados e análise. As atividades realizadas por demonstração também podem contribuir para o desenvolvimento de habilidades cognitivas e atitudinais por partes dos alunos.

O estudo das habilidades cognitivas tem se enriquecido com os trabalhos de Uri Zoller. O autor argumenta que os objetivos desejados para o processo de ensino e aprendizagem serão alcançados conforme houver uma melhora nas habilidades cognitivas dos alunos.

Para Zoller (2002), as habilidades cognitivas podem ser definidas em duas categorias: as habilidades cognitivas de baixa ordem $(\underline{\operatorname{LOCS}})^{12}$ e as de alta ordem $(\underline{H O C S})^{13}$.

Habilidades Cognitivas de Baixa Ordem são caracterizadas por capacidades tais como: conhecer, recordar/relembrar a informação e/ou aplicar conhecimentos ou algoritmos memorizados em situações familiares e na resolução de exercícios; já as de Alta Ordem, são referidas como aquelas capacidades orientadas para a investigação, resolução de problemas (não exercícios), tomada de decisões, desenvolvimento do

\footnotetext{
${ }^{12}$ LOCS : Lower Order Cognitive Skills

${ }^{13}$ HOCS : Higher Order Cognitive Skills
} 
pensamento crítico e avaliativo. As atividades experimentais de orientação investigativa estão associadas ao desenvolvimento de habilidades de alta ordem, como definidas por Zoller (2002).

As práticas de laboratório nas quais os alunos seguem um procedimento tipo receita, coletam os dados, mas não os discutem ou os analisam têm-se demonstrado de baixo caráter cognitivo. Os alunos não compreendem o porquê do experimento, não desenvolvem uma síntese do que foi proposto. Pesquisas indicam que muitos estudantes resolvem os problemas de química usando somente estratégias algorítmicas e não entendem os conceitos químicos envolvidos (GABEL; SHERWOOD; ENOCHS, 1984). As atividades orientadas para o desenvolvimento cognitivo do aluno, podem permitir que estes construam suas explicações para a compreensão do fenômeno, estabelecendo relações entre os dados e fatos químicos observados. Pode-se oferecer ao aluno a oportunidade de pensar sobre o problema, resolvê-lo através da experimentação, relatar e discutir suas idéias, que poderão contribuir para o processo de conceituação do fenômeno químico.

Desta forma, em uma abordagem construtivista e investigativa como a defendida neste trabalho, ambos, o papel do professor e do aluno, são essenciais para que o trabalho experimental seja desenvolvido e executado a fim alcançar as metas do processo de ensino e aprendizagem. $O$ aluno, deixa de ser o agente passivo da aula e passa a agir sobre seu processo de pensamento, questionando, pensando, participando da construção do pensamento. O professor deixa de ser o transmissor de conhecimentos e passa a questionar seus alunos, conduzindo-os a elaboração de respostas condizentes com a visão científica, gerando questões e problemas que serão discutidos e refletidos à luz dos conhecimentos científicos, de forma a respeitar as distintas idéias e opiniões em sala de aula. 


\section{Revisão Bibliográfica}

A seguir, na seção 2.1, pretende-se realizar uma breve introdução sobre a história do laboratório no Ensino de Química. Não é objetivo desta dissertação aprofundar o tema, entretanto conhecer as raízes desta metodologia pode contribuir para a nossa compreensão sobre o desenvolvimento da estratégia, e também sobre o porquê e como as atividades são utilizadas hoje nas escolas ainda sobre influências de algumas concepções. Na seção 2.2 será apresentada uma revisão sobre as atividades experimentais investigativas e as habilidades cognitivas no Ensino de Ciências.

\subsection{A utilização do laboratório no Ensino de Química}

A utilização dos laboratórios químicos e da experimentação é antiga. Os alquimistas, apesar de não serem considerados estudiosos das ciências das matérias (GOLDFARB, 1987), misturavam minerais a fim de obter novos materiais e manuseavam aparelhos que seriam mais tarde utilizados por químicos e pesquisadores. Porém, o caráter da experimentação sofreu uma transformação com o surgimento da ciência moderna, exprimindo uma nova e diferenciada percepção do mundo e seus constituintes. Entretanto, não se sabe ao certo quando ocorreu a inserção da atividade experimental no ensino de química.

Embora haja controvérsias, alguns pesquisadores consideram Friedrich Stromeyer o primeiro professor alemão a utilizar os experimentos de laboratório no ensino das universidades alemãs. Outros pesquisadores consideram o alemão Justus Von Liebig o precursor do uso do laboratório no Ensino de Química, por divulgar o uso da metodologia por todo o mundo (SHEPPARD; HOROWITZ, 2006; MARR, 2006).

Liebig, além de contribuir com diversos artigos publicados em química orgânica na época, tornou-se renomado educador, e as práticas de laboratório planejadas e executadas por ele eram consideradas rigorosas por seus alunos. Em uma das mais conhecidas e divulgadas, seus alunos deveriam investigar o conteúdo de diversos frascos, identificados somente por uma letra do alfabeto. Esta atividade durava praticamente todo o verão alemão. Quando os alunos terminavam a 
investigação e obtinham suas conclusões, eram considerados aptos por Liebig para trabalharem na pesquisa de problemas individuais.

O bom resultado das atividades propostas por Liebig contribuiu para que seu método de ensino de laboratório se tornasse amplamente conhecido, uma vez que, ao obter a posição acadêmica, seus ex-alunos tentavam recriar o sistema em suas instituições de ensino.

Foi Eben Horsford que levou a metodologia de Liebig para os Estados Unidos, em 1844, e também foi o responsável por influenciar Charles W. Eliot com suas idéias advindas da Alemanha. Quando Eliot tornou-se reitor de Harvard, modificou as políticas de admissão da academia, permitindo que os cursos de ciências e laboratórios de ciências também se tornassem opção para admissão. Depois, como presidente do "Commitee of Ten"14 tornou o trabalho laboratorial obrigatório no currículo das escolas secundárias. Assim, o método desenvolvido por Liebig, importado por Horsford e desempenhado por Eliot, tornou-se um método de ensino estabelecido na educação em ciências nos Estados Unidos.

A influência do método de Liebig determinou o estilo de experimentos adotados nas escolas e academias americanas, as quais apresentavam o ensino de laboratório tão restrito quanto os da Europa. Os estudantes geralmente não podiam manusear os aparelhos e vidrarias e se limitavam a assistir ao professor de química realizar os experimentos.

Há informações de que a inserção das aulas de laboratório nas escolas inglesas ocorreu aproximadamente em 1865. Entretanto, essas atividades desenvolvidas e executadas na época, tinham 0 interesse de desenvolver habilidades e atitudes científicas com o objetivo de formar cientistas.

No Brasil, um trabalho realizado pelo professor Simão Mathias, sobre os "Cem Anos de Química no Brasil", contribuiu para a história da química e do laboratório de química principalmente nas Universidades. Em seu trabalho, o autor declara que, apesar de o ensino médico ter sido iniciado em 1808, foi na segunda metade do século que as Faculdades de Medicina começaram a atribuir maior importância ao ensino e à divulgação da Química (MATHIAS,1975).

\footnotetext{
${ }^{14}$ Grupo formado por educadores para padronizar o currículo das escolas secundárias americanas.
} 
Ainda, segundo o autor, a reforma de 1884 contribuiu para o desenvolvimento do ensino prático no Brasil, prevendo preparadores e auxiliares técnicos nos laboratórios de Química Mineral, Orgânica e Farmácia.

O Instituto de Química da Faculdade de Engenharia de Belo Horizonte iniciou suas atividades em 1921 e teve como mérito a introdução de métodos análogos aos usados na maioria das escolas superiores européias, ou seja, aulas teóricas sempre acompanhadas de experimentos fundamentais, assim como o trabalho prático individual e intenso de cada aluno em lugar fixo nos diversos laboratórios. Mas, em 1931 o Instituto foi fechado, pois segundo seus diretores, na época, esta nova orientação não produziu os frutos que se esperam (MATHIAS, 1975).

Em 1934 foi criada a Faculdade de Filosofia, Ciências e Letras em São Paulo e coube ao professor alemão Heinrich Rheinboldt organizar, desenvolver e dirigir os cursos do setor de ciências químicas. O professor considerava as aulas de laboratório extremamente importantes e as organizava segundo a tradição alemã, baseando o ensino nas preleções acompanhadas de experiências demonstrativas, com o trabalho intenso dos alunos que dedicavam-se praticamente às aulas normais do currículo em tempo integral (MATHIAS, 1975).

Pode-se perceber que, a metodologia de Liebig, da mesma forma que influenciou diversos países europeus e os Estados Unidos, também teve grande influência no ensino das universidades brasileiras.

Sicca (1990) realizou um trabalho de investigação sobre a experimentação nas escolas secundárias brasileiras e suas relações com as propostas políticas da época de 1930 a 1984.

Segundo a autora, do período de 1930 a 1945, a experimentação foi introduzida no ensino secundário de Química como fator de motivação, e eram realizadas por demonstrações pelos próprios professores; poucas escolas propunham a realização de atividades experimentais individuais. Ou seja, as concepções de ensino experimental advindas dos períodos anteriores e de países estrangeiros permaneceram nas escolas brasileiras neste período.

Do período de1945 a 1964, segundo Sicca, ocorreram as lutas para a criação das Leis de Diretrizes e Bases da Educação Brasileira (promulgada em 1961) e a Campanha de Defesa da Escola Pública. Segundo estas propostas, o ensino de química deveria cumprir suas finalidades educativas, ou seja, a formação do espírito científico no aluno. Diferentemente da proposta anterior, na qual os professores 
utilizavam os experimentos demonstrativos para confirmar ou ilustrar conceitos já ensinados aos alunos; nesta perspectiva, deveriam realizar o experimento e desenvolver o raciocínio científico. Assim, por meio do método indutivo, os alunos deveriam desenvolver a capacidade de observação dos fenômenos, induzindo as leis a partir dos fatos, tendo as hipóteses como norteadoras do conhecimento e orientadoras de novas descobertas. Os alunos, então, deveriam relacionar os dados com os conceitos, interpretar os fatos para então adquirir o conhecimento científico. Porém, mesmo tentando mudar o cenário dos experimentos no ensino, uma situação encontrada desde aquela época e muito comum nos tempos atuais dificultou a implementação efetiva da idéia proposta: os baixos salários dos professores, as más condições da formação inicial, a dificultosa relação estabelecida entre o professor e o diretor da escola, e os laboratórios não totalmente equipados (SICCA, 1990).

Assim, a proposta que surgiu para privilegiar o raciocínio científico do aluno através de atividades experimentais, terminava por confirmar conceitos já estudados com experimento estritamente expositivos.

A formação de professores das áreas científicas para as escolas secundárias, nessa época, era centralizada na Faculdade de Filosofia, Ciências e Letras da USP, a qual privilegiava a pesquisa científica e seu ensino se baseava em demonstrações ou investigações, diferentemente das escolas secundárias que utilizavam os experimentos para confirmação de conceitos já estudados. A formação de professores por esta instituição poderia, portanto, contribuir para uma nova direção e perspectiva para o uso da experimentação no Ensino de Química. Entretanto, o que se verificou nos anos seguintes, e o que ainda se observa nos dias atuais, não condiz com o exposto.

No período compreendido entre 1964 e 1984, a utilização de atividades demonstrativas e expositivas ainda era predominante. Em 1965, foram publicadas as sugestões para o roteiro de Química, que tinham como objetivo orientar os professores em sua prática. Os roteiros sugeriam que o Ensino de Química deveria estimular a capacidade de observação e raciocínio no aluno, elementos essenciais para a compreensão dos conhecimentos científicos (SICCA, 1990).

Diferentemente das instruções anteriores, essas novas orientações enfatizavam a participação dos alunos na compreensão dos conceitos e princípios da química. Esta legislação recebeu influência de projetos americanos como o Chem 
Study ${ }^{15}$ e $\circ$ BSCS $^{16}$. Estes projetos foram traduzidos para diversas línguas e disseminados em diversos países e se fundamentam na visão empiricista das Ciências, na qual todo o conhecimento deriva da experimentação.

Esses projetos foram desenvolvidos na mesma época do lançamento do Sputnik pela Rússia, e assim, os EUA sentiram a necessidade de avançarem nas pesquisas e na formação de cientistas. Uma parte do prefácio do Chem Study evidencia essa necessidade: "Até certo ponto, o aluno que fizer uso deste material se tornará um cientista". Assim, estes projetos tinham como intenção formar cientista, e para isso, era preciso que os estudantes aprendessem a observar e registrar dados, a pensar de forma científica, desenvolver habilidades e técnicas no manuseio do instrumental do laboratório (GALIAZZI et al., 2001).

Esses projetos foram relevantes para o desenvolvimento da área de educação em ciências pois, além de direcionar as legislações anteriores, contribuíram para a formação inicial e continuada de professores que recebiam cursos de aperfeiçoamento profissional sobre esses projetos. Os alunos também tinham a oportunidade de participar da realização dos experimentos, entretanto as atividades propostas eram estruturadas e limitavam o aluno a seguir passos determinados, tratando a Ciência como um método único, infalível e isenta de erros.

Ainda que um dos objetivos do Chem Study, conforme pode-se observar em seu prefácio, fosse a participação do aluno nas etapas de investigação, ao examinar a obra, verifica-se que nas atividades propostas prevalecem concepções indutivistas, como por exemplo, a concepção de que tudo se inicia a partir da observação, podendo-se, a partir de fatos, obter os princípios.

Pressupostos norteadores desses projetos receberam e ainda recebem críticas com relação a suas idéias sobre o conhecimento científico. Segundo Barberá e Valdés (1996, p. 368):

Esta visão fortemente indutivista do método científico, que o vê como uma sucessão de passos discretos, têm recebido numerosas e contundentes críticas, e na atualidade está desacreditada em numerosos setores, mas está muito distante de ser erradicada do mundo do ensino de Ciências. Hoje se considera a observação dependente da teoria; é a teoria que determina o que e como tem que se observar.

Os mesmo autores fazem uma revisão sobre a efetividade do trabalho prático no ensino de ciências e criticam os principais objetivos pelos quais essas atividades

\footnotetext{
${ }^{15}$ CHEM Study -Chemical Education Material Study

${ }^{16}$ BSCS - Biological Sciences Curriculum Study
} 
são utilizadas em sala de aula, evidenciados em trabalhos de pesquisa realizados por diversos autores (BARBERÁ; VALDÉS, 1996).

A motivação, o desenvolvimento de habilidades técnicas e manipulativas e a formação de cientistas são os objetivos mais citados por professores universitários e de ensino médio para a experimentação. Assim, observamos que algumas concepções tradicionalistas ainda permanecem no desenvolvimento e execução de atividades experimentais no ensino de química.

Segundo Barberá e Valdés (1996), as atividades experimentais deveriam ser elaboradas e executadas com o objetivo de desenvolver habilidades cognitivas e raciocínio lógico, e não somente destrezas manuais e técnicas instrumentais.

Por fim, a história do ensino experimental em química nas escolas secundárias e universidades evidencia que esta estratégia foi norteada por princípios empiristas e indutivistas por um longo período. Mesmo tentando-se implementar novas abordagens, essas raízes ainda parecem predominar, conforme será exposto a seguir; o que evidencia a necessidade de novas pesquisas sobre o ensino experimental em química.

\subsection{Pesquisas sobre atividades experimentais investigativas e habilidades cognitivas no Ensino de Ciências}

Muito já se pesquisou sobre atividades experimentais em ciências. Mais recentemente, algumas pesquisas têm direcionado seus objetivos para 0 desenvolvimento cognitivo dos alunos dessas atividades. Desta forma, é relevante que uma revisão de alguns trabalhos na área seja realizada para ampliarmos o entendimento sobre esta estratégia, e também para avaliarmos a continuidade de pesquisas correlatas.

Diante das críticas de pesquisadores e professores com relação à efetividade de atividades experimentais, como já apontado anteriormente, pesquisas direcionam a investigação de novas estratégias com o objetivo de identificar suas potencialidades e dificuldades.

Será apresentada aqui, uma revisão de algumas destas investigações que podem contribuir para a procura de melhores resultados da utilização da experimentação no ensino de química e de ciências. 
Fernandes e Silva (2004) analisaram a perspectiva de alunos portugueses quanto às vantagens e dificuldades do trabalho experimental de investigação no desenvolvimento de competências científicas. O público-alvo era constituído de quarenta alunos pertencentes a duas turmas do $10^{\circ}$ ano do ensino secundário de Portugal na disciplina de Técnicas Laboratoriais de Biologia. Segundo as autoras, todos os alunos participantes apresentavam desempenho acadêmico semelhantes e, até o início da pesquisa, eram limitados a realizar experimentos verificacionistas, seguindo instruções de um protocolo no sentido de comprovarem um conceito já estudado previamente em sala de aula.

Foi proposto como problema para os alunos investigarem os constituintes químicos da castanha, um alimento muito importante para a região; assim, ao pesquisarem um assunto de interesse, os alunos poderiam se sentir mais motivados e desafiados na atividade.

A pesquisa foi desenvolvida em três etapas: fase pré-operacional, operacional e pós-operacional. $\mathrm{Na}$ fase pré-operacional, um questionário foi aplicado pelas pesquisadoras para os alunos responderem, com o objetivo de avaliar a percepção destes sobre a sua participação nos trabalhos experimentais realizados habitualmente, ou seja, os experimentos tradicionais ${ }^{17}$ e suas perspectivas com relação ao experimento investigativo. Depois, os alunos foram expostos ao problema e delinearam uma estratégia para sua resolução, com elaboração de hipóteses, plano de investigação e posterior comunicação para a classe para refletirem sobre a viabilidade das propostas e para trocarem idéias com os pares.

$\mathrm{Na}$ fase operacional, os alunos realizaram os experimentos e organizaram grupos para a discussão dos resultados. Por fim, na fase pós-operacional, os alunos discutiram os resultados com a sala e responderam a um segundo questionário proposto pelas investigadoras, que avaliava as concepções dos alunos sobre o experimento investigativo realizado. Ambos os questionários continham questões que permitiam respostas abertas e fechadas. As questões de respostas fechadas foram analisadas quantitativamente e para as questões de respostas abertas utilizou-se a análise de conteúdo.

\footnotetext{
${ }^{17}$ Entende-se aqui por experimentos tradicionais aqueles que são utilizados com o objetivo de comprovar fatos e teorias limitando a participação do aluno, não dando a oportunidade para estes participarem dos processos de uma investigação científica, como elaboração de hipóteses, proposição de soluções para o problema, pensamento crítico e avaliativo sobre os dados e os resultados. Estes experimentos podem ser realizados pelos alunos na bancada do laboratório ou demonstrados pelo professor.
} 
O questionário I, realizado na fase pré-operacional evidenciou que 29 dos 40 alunos entrevistados realizavam experimentos, mas quando questionados sobre sua participação nas etapas da investigação, os resultados revelaram que a grande maioria não tinha a oportunidade de formular o problema (22 alunos nunca formularam um problema), formular hipóteses (20 alunos nunca formularam hipóteses) e planejar os experimentos (12 alunos nunca planejaram um experimento).

Com relação às expectativas de sua participação em atividades investigativas, os alunos manifestaram preferência para o processo de elaboração de hipóteses, formulação de problemas e planejamento experimental. Essas fases eram as menos freqüentes nos experimentos tradicionais realizados por eles. Os alunos demonstraram o desejo de realizar experimentos mais desafiadores. Um dos alunos justificou sua resposta da seguinte forma:

"Formulação do problema e planejamento experimental são as fases que nos levam a pensar e porque nunca planejei um experimento, gostaria de o fazer. Podemos não acertar de primeira e os resultados não darem certo e ter que formular novas hipóteses. Quando nos é dado o protocolo, limitamo-nos a realizar a experiência e apenas a tirar conclusões."

O questionário II, realizado após o experimento, revela que os estudantes consideram a elaboração de hipóteses como uma das etapas mais importantes da investigação, conforme mostra a frase a seguir:

"A formulação de hipóteses é importante porque nos faz utilizar todos os nossos conhecimentos, temos que pensar bastante e não nos podemos esquecer de cada pormenor do problema”.

As autoras enfatizam como fatores que os alunos consideram importantes no trabalho investigativo a reflexão sobre os erros, o pensamento crítico, as conclusões, a discussão e comunicação dos resultados e o trabalho em grupo. Alguns alunos afirmam sua preferência em realizar atividades investigativas sugerindo como vantagens os fatores acima, e também o aumento da responsabilidade, da autonomia, perseverança e auto-motivação.

As autoras concluem o artigo argumentando sobre as limitações subjacentes que estudos desta natureza podem enfrentar, mas contudo, consideram seus dados 
relevantes, uma vez que revelou a preferência dos alunos por atividades que exigem maior exercício do raciocínio.

A pesquisa descrita limitou-se a investigar a preferência dos alunos com relação ao tipo de atividade experimental a qual estão expostos. Nada pode ser afirmado sobre aprendizagem ou desenvolvimento de habilidades, o que torna 0 trabalho um pouco limitado. Porém, deve-se considerar que conhecer a opinião dos alunos sobre os processos que envolvem uma investigação e sua preferência quanto ao tipo de experimento a ser realizado, pode contribuir para que professores reflitam sobre o tipo de experimento que estão realizando com seus alunos e sobre sua efetividade nos laboratórios.

Outras investigações, entretanto, analisam as causas ou resultados que determinado tipo de experimento pode ou não produzir.

Zuliani (2000), investigou a eficiência da metodologia investigativa com alunos da disciplina de Laboratório de Química Geral e Inorgânica do terceiro termo do curso de Licenciatura em Física. A pesquisadora trabalhou com um grupo de 15 (quinze) alunos e tinha como principal objetivo aplicar a metodologia investigativa e avaliar as potencialidades dessa estratégia. Assim, os alunos, em grupos, deveriam escolher um tema em química para trabalhar no laboratório, pesquisar e elaborar o projeto para sua realização, desenvolver o experimento, elaborar um relatório e apresentá-lo.Todas estas fases tinham o apoio do professor, que estava disponível para quaisquer dúvidas e dificuldades relacionadas ao experimento ou à metodologia.

Foi observado nessa investigação, que o desenvolvimento de habilidades cognitivas como espírito crítico, reflexão, formulação de novas hipóteses, tomada de decisões foram favorecidas pelo uso da metodologia. Estes dados foram analisados pela pesquisadora através das transcrições das falas dos grupos durante todo o processo de investigação e também com entrevistas com os alunos.

Segundo a autora, a estratégia permitiu maior autonomia e responsabilidade por parte dos alunos ao perceberem que sua aprendizagem independe das respostas do professor. Porém, com relação à análise e discussão dos resultados sobre o problema proposto como investigação para cada grupo de alunos, a pesquisa não encontrou resultados tão positivos. Embora os alunos demonstrassem facilidade na proposição de novas hipóteses para o problema, encontravam dificuldade na descrição do procedimento para seu teste e algumas vezes não 
consideravam a hipótese na análise dos dados. A autora atribui estes resultados ao baixo nível de liberdade existente nas atividades experimentais tradicionais executadas nas escolas e também à pouca flexibilidade desses procedimentos, que geralmente ficam detidos a respostas da questão central proposta pelo professor.

A pesquisadora relata que pouco tempo foi dedicado para a realização da comunicação dos resultados das investigações realizadas pelos grupos, e sugere ser esta uma etapa importante da atividade, uma vez que permite momentos de discussão e avaliação dos resultados por parte dos alunos e também pelo professor. É importante enfatizar que, mesmo se tratando do ensino superior, a pesquisadora encontrou dificuldades relacionadas ao tempo que este tipo de atividade pode exigir.

Uma pesquisa realizada por Domin (1999b) pode corroborar os dados de Zuliani com relação a algumas dificuldades encontradas pelos alunos no desenvolvimento e execução das atividades experimentais investigativas. Para Domin (1999b), as atividades de laboratório freqüentemente apresentam natureza de "receita de cozinha" e são planejadas com o propósito de consumir mínimos recursos, tempo, espaço, equipamentos e pessoal. Pouca ênfase é dada ao planejamento experimental e interpretação dos resultados.

Ainda, para ele, duas explicações podem ser dadas para a ineficácia das atividades experimentais. A primeira se refere ao tempo que os estudantes perdem determinando se o resultado obtido é o correto e não planejando e organizando os experimentos. Segundo, as atividades experimentais de caráter tradicional facilitam o desenvolvimento de habilidades cognitivas de baixa ordem (aprendizagem mecânica, resolução de problemas algorítmicos).

O autor analisou 10 manuais de laboratório de química geral para investigar se foram elaborados de forma a proporcionar o desenvolvimento de habilidades cognitivas de alta ordem. Os dados foram analisados de acordo com a taxonomia de Bloom $^{18}$. Segundo Domin, esses processos podem ser dicotomizados em baixa e alta ordem de processo mental, onde conhecimento, compreensão e aplicação podem ser considerados cognições de baixa ordem; enquanto, análise, síntese e avaliação, são consideradas cognições de alta ordem. Assim, reconhecer, recordar

\footnotetext{
18 A taxonomia de Bloom para os objetivos educacionais é uma representação hierárquica de seis processos cognitivos: conhecimento, compreensão, aplicação,análise, síntese e avaliação. Cada processo utiliza as capacidades adquiridas nos níveis anteriores.
} 
ou aplicar conhecimentos requer processos cognitivos da baixa ordem, enquanto inferir, avaliar e analisar requer processos cognitivos de alta ordem.

A análise de Domin consistiu em identificar verbos que indicassem cada um dos tipos de habilidade cognitiva, entretanto, pelo fato de o verbo poder denotar mais do que um tipo de habilidade cognitiva, o contexto da frase que continha o verbo também foi averiguado. Assim, por exemplo, a afirmação "descreva como um catalisador aumenta a velocidade de reação" indica compreensão, porém "descreva um experimento que possa determinar a lei de velocidade para a reação a seguir" indica síntese.

A análise dos manuais revelou que os experimentos requerem, de maneira geral, o uso das três habilidades de baixa ordem. Oito, de dez manuais analisados, requerem que os estudantes operem predominantemente nestes três níveis da taxonomia de Bloom (conhecimento, compreensão e aplicação). Poucas atividades requerem dos estudantes habilidades cognitivas de alta ordem: 54\% delas requerem análise, e somente 4\% delas requerem síntese e avaliação.

O autor ainda verificou que apenas um dos materiais que favorecem somente baixa ordem de cognição não apresenta a seguinte estrutura: (1) uma introdução onde o conceito é apresentado e explicado; (2) um procedimento passo a passo; (3) tabelas para serem preenchidas com dados ou resultados; (4) questões pré e póslaboratório que requerem conhecimento, compreensão e aplicação.

Domin, ainda faz uma comparação dos manuais com um catalisador. Segundo ele, o catalisador acelera a reação química para fornecer um caminho alternativo de mais baixa energia; o manual de laboratório reduz o tempo necessário para totalizar uma atividade de laboratório pelo fornecimento de um caminho instrucional que não requer a utilização de habilidades de pensamento de alta ordem. Assim, para ele o manual de laboratório tem de se tornar um instrumento que maximiza a eficiência do laboratório no favorecimento do uso de cognição de alta ordem.

Ainda, com relação ao desenvolvimento e manifestação de habilidades cognitivas em atividades experimentais investigativas, Hofstein et al. (2005) investigaram a habilidade dos estudantes em questionar seus dados e conclusões em um experimento investigativo. Assim, o principal objetivo da pesquisa foi investigar se, quando os estudantes têm oportunidades e tempo para desenvolver habilidades de investigação nos laboratórios de química, estes podem fazer mais e 
melhores questões, hipóteses e questionar o experimento, quando comparado com estudantes que foram limitados a experimentos tradicionais durante o processo de ensino.

O público-alvo foi constituído de dois grupos de alunos do ensino médio de química, um grupo participante de atividades experimentais investigativas (grupo experimental) e outro grupo participante de atividades tradicionais de laboratório (grupo controle). Segundo os autores, no laboratório tradicional os alunos conduzem um experimento a fim de confirmar fatos (seguindo passo a passo as instruções procedimentais através do manual de laboratório). As questões neste tipo de experimento são geralmente fechadas e estão diretamente relacionadas com os conceitos que estão sendo estudados em sala de aula. Assim esses estudantes tiveram tempo e oportunidades limitadas para desenvolver competências que caracterizam as atividades investigativas, como por exemplo, elaborar questões e hipóteses, planejar o experimento, analisar e predizer resultados. Os autores aplicaram cerca de 15 experimentos investigativos (no grupo experimental) ou tradicionais (no grupo controle), em escolas de Israel por dois anos, com 111 alunos; destes, 55 faziam parte do grupo experimental e 56 do grupo controle. Os grupos no laboratório eram formados por três ou quatro estudantes.

Após essas aulas, a fim de comparar o grupo experimental e controle quanto suas habilidades de pensar sobre o problema e fazer mais e melhores questões quando diante de experimentos, os grupos participantes da pesquisa deveriam conduzir um experimento simples. Cabe ressaltar que este experimento era novo para ambos os grupos.

Durante a realização da atividade experimental, os alunos deveriam anotar suas observações e também fazer todas as anotações necessárias que considerassem relevantes para compreender o fenômeno observado e; escolher uma questão para futuras investigações, sugerir uma resposta para essa questão, e propor um experimento que pudesse apoiar a sua hipótese. Os estudantes do grupo controle, obtiveram uma pequena explicação pré-laboratório com exemplos sobre as questões para investigação e hipóteses, seleção da questão para investigação e planejamento de um experimento satisfatório para responder à questão.

$\mathrm{Na}$ análise dos resultados, os autores consideraram o nível das questões apresentadas pelos dois grupos como: (1) questões de nível baixo: que são relatadas por fatos e explicações do fenômeno ou são observadas no experimento 
pelos estudantes e, (2) questões de nível alto: que são questões que não podem ser respondidas somente na investigação, mas precisam de outro experimento ou de maiores informações em literatura, sendo mais complicadas, favorecendo o pensamento crítico sobre elas.

Como os alunos respondiam aos questionários individualmente, os pesquisadores verificaram que os estudantes do grupo experimental fizeram mais perguntas de nível alto do que o grupo controle, assim, enquanto o grupo experimental elaborou 123 questões de alto nível, o grupo controle elaborou somente 18. Porém, nenhuma diferença significante foi observada com relação ao número de questões de nível baixo, cerca de 184 para o grupo experimental e 165 para o grupo controle. Os autores atribuíram esses resultados à instrução prévia dada aos alunos para que escrevessem todas as questões que viessem a sua mente. Assim, a grande diferença entre os grupos está no número de questões de alto nível.

Quanto às questões que os alunos escolheram para avançar as investigações, os pesquisadores verificaram que vários estudantes do grupo controle não escolheram qualquer questão, e quando as selecionavam, a maioria delas eram questões de nível baixo. Os estudantes do grupo experimental escolheram questões de nível alto, que eram formuladas com uma ou mais variáveis. Assim, os pesquisadores evidenciam que os estudantes melhoram suas habilidades de perguntar mais e melhor como resultado de um ganho de experiência com os experimentos investigativos. Para eles, esse resultado não foi surpresa, pois questionar é uma atividade que os alunos participantes de atividades investigativas fazem a todo o momento. Diferentemente, os estudantes do grupo controle, que haviam aprendido com experimentos tradicionais, não tiveram a oportunidade de praticar a habilidade de questionar e especificamente elaborar questões investigativas (de nível alto). Desta forma, suas habilidades de questionamentos indicadas no teste proposto foram de nível baixo.

Por fim, os autores argumentam que mais pesquisas precisam ser realizadas para investigar a efetividade de diferentes modelos de ensino, em particular os experimentos investigativos em ciências.

Uma outra linha de pesquisa, ainda com relação às habilidades cognitivas, também tem crescido na pesquisa em ensino de ciências: o ensino argumentativo. $O$ processo de argumentação contribui para o desenvolvimento de habilidades 
cognitivas em sala de aula ou nos laboratórios de ciências, pois permite aos alunos empregar o conhecimento científico para identificar perguntas, tomar decisões, elaborar hipóteses e possíveis soluções para o problema proposto.

Locatelli (2006) investigou como os alunos de ensino fundamental, quando imersos em atividades experimentais de conhecimento físico baseadas na metodologia de ensino por investigação, encontram condições para desenvolverem argumentos que estejam de acordo com o padrão "se, e, então, e/mas, portanto". O autor analisou aulas nas quais o professor propõe um problema físico para os alunos, em grupos, por meio de atividades experimentais. No decorrer das aulas, os alunos tiveram a oportunidade de formular hipóteses, realizar o experimento, analisar os dados e chegar a possíveis conclusões. Depois da realização dos experimentos, o professor realizava uma discussão com toda a classe a fim de promover um ambiente de discussão e argumentação para que os alunos pudessem avaliar suas hipóteses. O professor também propunha questões simples que apresentassem o termo "Se..." para que os alunos pudessem avaliar melhor o raciocínio desenvolvido no processo de resolução do problema.

Ao analisar os resultados, o pesquisador relata que pouco tempo foi dedicado para a realização de alguns experimentos, fazendo com que poucos argumentos e hipóteses surgissem durante sua execução, além de que muitos gestos e gírias foram utilizados pelos alunos, dificultando o processo de análise.

Porém, quando o tempo para a realização da atividade experimental foi maior, muita interação ocorria entre os alunos, revelando melhores resultados quanto ao desenvolvimento da argumentação. Nestas atividades, segundo o autor, foi possível encontrar na fala dos alunos os ciclos "Se..., então...", a fim de construírem uma justificativa. É importante salientar que a aceitação ou refutação das hipóteses formuladas pelos alunos estava baseada nos dados empíricos observados durante a experimentação.

Quando o professor perguntava o "por quê?" aos alunos, para que eles refletissem sobre suas relações causais e o efeito da sua manipulação sobre 0 objeto, dos cinco experimentos realizados, somente em dois os alunos utilizaram o termo "portanto". Segundo o autor, em um dos experimentos não houve tempo suficiente para o professor realizar a pergunta; em outros dois, os alunos não chegaram a expressar explicações causais, pelo fato de se tratar de um conceito 
físico de difícil compreensão por crianças dessa faixa etária, o que contribuiu para que as explicações estivessem embasadas em variáveis diretamente proporcionais.

$\mathrm{Na}$ análise textual, nem sempre os termos da estrutura hipotético-dedutiva foram evidentes, sendo necessária a interpretação e conseqüente inserção destes termos nas falas transcritas dos alunos. O trecho a seguir mostra como o autor analisou a fala dos alunos durante o experimento do looping, o qual utiliza o princípio de conservação de energia para sua resolução. Quando o autor utiliza "<>" na fala transcrita dos alunos, significa que foram inseridas palavras nestas falas para mostrar sua análise, ou seja, não necessariamente os alunos precisam usar explicitamente o termo se...então.

Aluno5: "Porque <se> ela está em cima, <então> ela pega muita pressão e <se> ela está mais para baixo <então> ela pega menos pressão e não dá a volta completa, ela vai um pouquinho menos e cai na cesta."

O papel do professor, segundo o autor, é de suma importância para atribuir o nome correto de cada conceito ou material utilizado no experimento e para fortalecer pontos específicos das explicações, contribuindo para a construção da linguagem científica e também para estimular a fala dos alunos.

Por fim, o autor considera que nem todos os alunos apresentaram as estruturas hipotético-dedutivas, pois alguns deles precisavam de mais tempo para organizar seu raciocínio e argumentar. Porém, as intervenções do professor foram de extrema importância ao criar um ambiente de discussão e questionamento, conduzindo os alunos a indagarem o porquê do experimento e suas causas.

Capecchi e Carvalho (2002) também investigam o raciocínio argumentativo desenvolvido por alunos em aulas de física. Neste trabalho, as autoras investigam a argumentação de crianças na faixa etária de 8 a 10 anos em atividades experimentais de física. Nestas atividades, os alunos tiveram a oportunidade de realizar um experimento em grupo à procura de explicações para o problema proposto pelo professor. Após a realização do experimento, o professor realizou uma discussão com toda a classe em que foi solicitado que os estudantes explicassem como resolveram o problema e porquê aquela foi a melhor solução.

As autoras analisaram a argumentação dos alunos, tanto do ponto de vista estrutural, utilizando o padrão de argumento racional de Toulmin e a adaptação de Jiménez-Aleixandre, quanto das interações ocorridas na discussão, atribuindo níveis 
de qualidade para os argumentos, de acordo com as interações estabelecidas, utilizando as categorias desenvolvidas por Driver e Newton. A análise do discurso do professor foi baseada no trabalho de Mortimer e Machado.

Ao analisar os dados, as autoras verificam que os alunos se esforçaram para explicar o fenômeno estudado, uma vez que citaram dois conceitos físicos para solucionar o problema, conceitos estes ainda pouco elaborados por eles. Os alunos apresentaram muitas afirmações com justificativas e as relacionam com os dados obtidos e elaboram hipóteses a partir de suas conclusões.

Segundo a pesquisa, os alunos se sentiram estimulados a resolver o problema e a argumentar para convencer a professora e colegas quanto a sua explicação. Porém, as autoras verificaram que afirmações competitivas, como refutações por exemplo, não surgiram na fala dos alunos, o que pode ser atribuído ao fato de a discussão final ter se centrado no problema realizado, o que não permitiu uma extrapolação das argumentações. As autoras declaram que, em um outro estudo, encontraram resultados semelhantes aos dessa pesquisa, porém, como a discussão se estendeu para o cotidiano, os alunos tiveram a oportunidade de refutar ou elaborar afirmações competitivas.

Outra relevância dessa pesquisa se refere à análise discursiva das falas do professor. As autoras encontraram o padrão elicitativo como o predominante na aula, proporcionando a elaboração de argumentos por parte dos alunos em um ambiente de constante discussão, o que evidencia a importância da atitude do professor em sala de aula em promover ambientes de debate para que os alunos possam expor suas idéias.

Observa-se que diversas pesquisas têm sido realizadas sobre as habilidades que podem ser desenvolvidas em atividades experimentais, algumas com objetivos mais específicos de analisar as habilidades cognitivas dos alunos. Zoller (2002), também tem direcionado suas pesquisas para o estudo destas habilidades, tanto no laboratório quanto am aulas nas salas de química.

Em um de seus artigos, o autor tinha como objetivo avaliar o desempenho dos estudantes universitários ao responderem questões LOCS, HOCS e $\operatorname{ALG}^{19}$ e estabelecer diferenças e correlações entre os resultados obtidos no teste aplicado aos alunos e essas categorias. Com esses dados, os autores também puderam

\footnotetext{
${ }^{19}$ HOCS: Higher Order Cognitive Skills; LOCS: Lower Order Cognitive Skills; ALG: Algoritmic
} 
perceber o modo de pensar dos estudantes, avaliar suas atitudes para cada categoria de questão e identificar possíveis razões para as diferenças encontradas nas as questões LOCS, HOCS e ALG.

Os pesquisadores elaboraram seis questões que foram respondidas por 97 alunos de duas universidades Israelenses. Quatorze estudantes foram entrevistados para explanarem como resolveram as questões, procedimento este que contribuiu para que os pesquisadores respondessem as questões propostas na pesquisa.

Segue abaixo um exemplo de cada questão proposta pelos autores:

(ALG) Calcule a massa máxima do $\mathrm{SO}_{3}$ que pode ser obtida de 1.9 mols de oxigênio e um excesso de enxofre na reação $2 \mathrm{~S}+3 \mathrm{O}_{2} \rightarrow 2 \mathrm{SO}_{3}$.

(LOCS) $\mathrm{O} \mathrm{PH}_{3}$ ou $\mathrm{BH}_{3}$ são uma base ou ácido?

(HOCS) O potencial de ionização refere-se a energia necessária para remover um elétron do átomo. O primeiro potencial de ionização refere-se a energia necessária para remover o primeiro elétron, e o segundo potencial de ionização refere-se a remoção do segundo, etc. Qual destes você espera que tenha o maior potencial de ionização: o átomo de enxofre (S) ou o átomo de fósforo $(P)$. Explique.

A entrevista tinha como objetivo avaliar a atitude dos estudantes, assim, os autores os questionavam quanto à preferência, facilidade ou dificuldade encontrada para responder as questões.

Os autores verificaram que as questões nas quais os alunos tiveram melhor desempenho foram as algorítmicas, segundo eles, devido à capacidade dos alunos em aplicar algoritmos para resolver exercícios. Argumentam também, que um bom desempenho de um aluno em uma questão que requer habilidade cognitiva de baixa ordem, por exemplo, não necessariamente implica que este mesmo aluno tenha um bom desempenho em questão de maior exigência cognitiva; e que, questões que exigem habilidades de alta ordem cognitiva são mais difíceis para os estudantes produzirem respostas ou conceitos, o que acontece com freqüência com questões que exigem apenas a aplicação de algoritmos.

O artigo relata trechos das entrevistas com os alunos e comentários dos autores sobre as respostas dos estudantes. Um dos alunos entrevistados após a resolução da questão, relatou ter pensado que seu resultado final estava errado por ser diferente do que tinha obtido em uma prova realizada anteriormente à pesquisa. Dos 46 alunos de uma das universidades pesquisadas, 41 responderam uma das 
duas questões ALG de forma algorítmica, e somente 5 resolveram por raciocínio dedutivo ou lógico, corroborando a conclusão dos autores de que os alunos estão condicionados a "pensar algoritmicamente".

Com relação à atitude dos estudantes, a pesquisa revela que alguns alunos preferem questões que exigem habilidades cognitivas de alta ordem (HOCS), mas a grande maioria prefere as algorítmicas; e que os alunos vão à procura da resposta correta para a questão, exigência típica de questões ALG/LOCS. Além disso, os alunos ainda atribuem às questões LOCS maior dificuldade para resolução.

Os autores argumentam ainda que as estratégias de ensino e avaliação aplicadas nas escolas não são compatíveis com o desenvolvimento e fomento de habilidades cognitivas de alta odem (HOCS) nos estudantes, sugerindo pesquisas que orientem o movimento do ensino para o desenvolvimento de habilidades cognitivas como tomada de decisões, resolução de problemas, pensamento crítico, típicos de um processo de ensino e aprendizagem que valoriza as HOCS.

A habilidade de escrita também tem sido considerada por vários autores como um instrumento para a criação de um sistema conceitual coerente, uma vez que o discurso oral é altamente flexível, enquanto a escrita requer uma posição lógica e reflexiva, exigindo maior esforço cognitivo por parte do aluno.

A escrita como instrumento no processo ensino e aprendizagem possibilita ao aluno expressar suas idéias e concepções acerca dos fenômenos químicos de maneira mais estruturada e consolidada, uma vez que escrever exige habilidades de síntese e interação dos conhecimentos, demandando maior esforço cognitivo.

Rivard e Straw (2000) investigaram o papel da fala e da escrita na aprendizagem de ciências de estudantes da oitava série de escolas canadenses. $O$ objetivo foi explorar o efeito da fala, da escrita e da fala e da escrita na aprendizagem e na retenção de conhecimentos científicos, e descrever os mecanismos pelos quais a fala e a escrita mediam esse processo. Foram formados três grupos experimentais: (1) somente discussão: os alunos discutiam oralmente as questões problemas em grupo; (2) somente escrita: os alunos escreviam suas respostas individualmente mas sem terem discutido com outro aluno previamente; (3) combinando discussão e escrita: discutiam as questões previamente em grupos para depois escreverem suas respostas individualmente. Estes grupos recebiam questões problemas que envolviam a construção de explicações científicas 
aplicadas a conceitos de ecologia. Um grupo controle recebia questões descritivas mais simples baseadas no mesmo conteúdo

Os autores verificaram que a escrita é uma importante ferramenta para transformar idéias rudimentares em conhecimento mais estruturado e coerente. Ainda, a fala combinada com a escrita parece ter aumentado a retenção da aprendizagem de ciências por mais tempo, conforme revelaram os pós-testes realizados com os alunos do grupo experimental. Os alunos foram mais beneficiados com a utilização da estratégia de discussão e escrita do que com uma das estratégias isoladas.

Queiróz (2001) tem contribuído para a pesquisa da escrita no ensino de química, principalmente no ensino universitário brasileiro. Segundo a autora, a escrita é uma habilidade essencial para aqueles que seguirão as carreiras científicas, pois esta habilidade é exigida ao se escrever um relatório, um artigo ou documentos para solicitação de recursos para agências financiadoras.

A autora realizou uma revisão sobre alguns trabalhos internacionais sobre escrita realizados com alunos universitários. Os trabalhos revisados por ela, concordam quanto ao engajamento dos alunos nas estratégias propostas. Em geral, os alunos se sentem mais motivados e a interação professor-aluno é maior. Tarefas escritas propostas aos alunos para pensar sobre o problema e propor soluções fazem com que estes se esforcem a pensar sobre os conceitos químicos que os explicam e relacioná-los com o cotidiano. Essas pesquisas mostram que atividades nas quais os alunos precisaram solucionar problemas também aumentaram a discussão com os pares e a socialização do conhecimento, além de que, é claro, a escrita e criatividade dos alunos melhoram de maneira significante. Em uma das bibliografias revisadas ${ }^{20}$, o pesquisador verificou que, quando o professor exige dos alunos uma escrita inteligível, e estes percebem que não alcançaram tal objetivo ao responderem às questões propostas por ele, esta habilidade melhora gradativamente e os alunos passam a escrever e a exigirem mais de suas capacidades de escrita.

Santos e colaboradores (2006) propuseram para alunos universitários de Química a leitura de artigos científicos e posterior redação de resumos sobre os conteúdos destes. No final do semestre foram formados grupos de discussão para

\footnotetext{
${ }^{20}$ Meislich, E. K.; J. Chem. Educ., 64, p. 505, 1987.
} 
que os envolvidos compartilhassem suas experiências e os conhecimentos construídos. Os resumos dos alunos foram analisados segundo a análise do discurso.

Nos resultados, os pesquisadores verificaram que, além dos alunos relatarem a atividade como proveitosa para a aprendizagem de tópicos e assuntos ministrados na disciplina de Físico-Química I e, também, de assuntos ministrados em outras disciplinas; $27 \%$ dos alunos relataram durante a discussão que tiveram dificuldades para elaborar e escrever os resumos. Os alunos consideraram a atividade uma das poucas a permitir o aperfeiçoamento desta habilidade, a escrita. Os depoimentos abaixo evidenciam os resultados:

"Ajudou para escrever, para redigir. Mesmo para falar sou meio embaraçado, meio confuso. Foi legal nesta parte para eu escrever o texto. Eu escrevia uma frase, ficava olhando para ela e apagava. Não ficou legal. Eu mesmo me condenava. Escrevia de novo. Eu achei legal, me ajudou".

"Resumo, eu também tinha feito para a iniciação. Na graduação não tinha feito nada, porque os relatórios que a gente faz é mais parte experimental e conclusão. É meio sistemático: o procedimento, o que obteve e a conclusão".

A dificuldade evidenciada pelos pesquisadores ao desenvolverem a pesquisa com alunos universitários evidencia a necessidade de se investir em aulas onde o processo da escrita esteja envolvido. A escrita é essencial para qualquer carreira e profissão e estes dados não se restringem aos indivíduos que seguirão as carreiras científicas.

Oliveira e Carvalho (2004), analisaram os registros escritos e desenhos feitos por alunos do terceiro ano do ensino fundamental em atividades problemáticas experimentais de conhecimento físico.

Ao analisar os registros escritos dos alunos, as autoras constataram que houve uma preocupação por parte destes em descrever os fatos ocorridos em uma seqüência cronológica, contribuindo para que o leitor tenha uma melhor compreensão dos fatos. Desta forma, para o aluno escrever uma explicação demanda um esforço cognitivo muito maior e sua resposta tende a ser mais objetiva.

Estes resultados corroboram a necessidade de incorporação de atividades que visem desenvolver a habilidade da escrita no ensino de química. Ao 
responderem questões escritas sobre um problema experimental ou elaborarem relatórios e procedimentos laboratoriais, os alunos têm a oportunidade de sintetizar suas idéias e propor suas soluções para a questão investigada. Assim, as atividades experimentais investigativas podem contribuir para 0 desenvolvimento e manifestação de habilidades qualitativas nos alunos. 


\section{Metodologia da Pesquisa}

\subsection{Contexto da Pesquisa}

Apresenta-se neste capítulo a metodologia utilizada na pesquisa e o processo de elaboração das categorias de análise.

A pesquisa apresenta as características de uma abordagem qualitativa, uma vez que foram investigadas as respostas dos alunos durante uma atividade experimental investigativa, analisando as respostas escritas elaboradas pelos alunos e a transcrição de suas falas durante seqüências de atividades desta natureza.

Na pesquisa qualitativa, segundo Bogdan e Biklen (1994), a fonte direta de dados é o ambiente natural, constituindo o investigador 0 instrumento principal. $O$ pesquisador se insere em um contexto, neste caso a sala de aula, e procura elucidar questões educativas. Ele torna-se o instrumento principal da pesquisa, pois mesmo utilizando instrumentos tecnológicos para a sua coleta são suas concepções, sensações e interpretações que guiarão os resultados.

A escolha das escolas para a pesquisa justificou-se nos pressupostos que apóiam esta pesquisa, ou seja, uma escola em que o professor de química apresentasse em suas aulas uma metodologia de ensino que pudesse ser considerada construtivista, isto é, que tivesse como fundamento experimentos investigativos para a construção de conceitos químicos.

A seqüência da aula foi escolhida aleatoriamente, de forma a não ser planejada especificamente para atender os objetivos do trabalho, mas o de minimizar possíveis interferências e manter o ambiente da sala de aula o mais real possível. Assim, a pesquisadora não influiu no planejamento e execução da aula em nenhum momento, e permaneceu na sala com o único objetivo de coletar os dados.

\subsection{Público alvo}

Para a escolha do público-alvo foi preciso selecionar e identificar escolas e professores que apresentassem as características que direcionam a pesquisa.

Duas escolas foram selecionadas: uma escola será denominada Escola A e a outra Escola B; conseqüentemente, as professoras de química regentes das escolas serão denominadas respectivamente, professora $A$ e professora $B$. 
A seguir, apresentam-se as características das escolas e do público alvo; ou seja, professores e alunos participantes.

\section{Descrição da Escola A}

A escolha da escola A foi determinada para a pesquisa por dois motivos: (1) por sediar ou executar pesquisas de interesse próprio e de universidades, conforme descrito em seu projeto pedagógico e (2) as aulas da professora de química se enquadrarem nos pressupostos defendidos neste trabalho.

O trabalho exercido pela professora na escola $A$ já era de conhecimento da pesquisadora, porém, para validar as evidências de uma prática construtivista e investigativa, um questionário elaborado com pressupostos do referencial teórico que conduz a pesquisa, foi respondido pela professora (Anexo A).

Uma outra evidência que corroborou a postura construtivista da professora está relacionada ao material didático utilizado em suas aulas. O material "Interações e Transformações I - Elaborando Conceitos sobre Transformações Químicas" foi elaborado por um grupo de professores e pesquisadores denominado Grupo de Pesquisa em Educação Química (GEPEQ), que se preocupava com um ensino no qual os conteúdos químicos não fossem apenas memorizados pelos alunos, mas, construídos com o auxílio do professor. Assim, os conceitos são desenvolvidos por meio de tabelas avaliativas, experimentos investigativos, questões problematizadoras, análise de dados e situações contextualizadoras.

$\mathrm{Na}$ proposta pedagógica de química dessa escola consta, como objetivos de aprendizagem, o desenvolvimento de habilidades como interpretação e classificação de dados e tabelas, estabelecimento de relações, desenvolvimento de postura crítica, colaboração entre pares, entre outras características próprias da postura construtivista.

Algumas aulas antes das gravações também foram acompanhadas pela pesquisadora para evidenciar esses pressupostos e também para criar um ambiente receptivo com os alunos para a realização das gravações, uma vez que muitos alunos podem se sentir incomodados com a presença da câmera ou com uma pessoa que não faz parte do seu contexto. Esse fator foi ainda minimizado pelo fato de os alunos do colégio estarem, em parte, acostumados com gravações e pesquisas realizadas por universidades.

Os alunos faziam parte de duas turmas da primeira série do ensino médio - Primeira Série I e Primeira Série II. As duas classes foram sugeridas pela professora por 
apresentarem alunos participativos. Cada classe era composta por aproximadamente trinta alunos.

A escola apresenta infra-estrutura para a realização de atividades experimentais. A sala de aula é integrada ao laboratório e facilita a realização de experimentos, principalmente os de demonstração devido ao rápido acesso aos materiais. O laboratório contém vidrarias e reagentes suficientes para a realização das atividades e conta com o auxílio de um técnico, outro fator que contribui para a realização das atividades experimentais.

A professora é bacharel e licenciada em Química, tem mestrado na área de Ensino de Ciências e atua no Ensino Médio há 10 anos. O seu regime de trabalho na escola é de 30 horas semanais, das quais, 15 horas são dedicadas às aulas e as restantes são voltadas para reuniões, atendimento a estagiários e para a preparação de atividades e projetos. Esses fatores contribuem significativamente para 0 planejamento de atividades experimentais, uma vez que um dos fatores mais citados pelos professores para a ausência de atividades experimentais é a falta de tempo para o seu planejamento (LIMA, 2004).

\section{Descrição da Escola B}

A escola B localiza-se na zona leste de São Paulo. Os alunos participantes da pesquisa eram da Primeira Série do Ensino Médio. A sala era composta por aproximadamente quarenta alunos, porém o número de alunos que entregaram os seus materiais no final do conceito investigado, temperatura de fusão, foi 27.

A escolha da escola B se justifica pelo fato de a professora utilizar atividades experimentais investigativas e considerar que a sua postura em sala de aula apresenta características do construtivismo, conforme evidencia o questionário respondido por ela (Anexo B). Porém, em conversas informais após as aulas, a professora algumas vezes relatava à pesquisadora que ainda não se considerava uma professora construtivista, pois ainda precisava adotar outras atitudes características.

A professora utilizava um material didático para guiar as suas aulas. $O$ material "PROQUIM: Projeto de Ensino de Química para o Segundo Grau" foi desenvolvido na década de oitenta, época na qual as novas metodologias e estratégias de ensino surgiam visando a melhoria do processo de ensino e 
aprendizagem. A utilização desse material pode também corroborar a postura construtivista da professora.

Nesse material, os conceitos são construídos a partir de experimentos investigativos, os quais partem de um problema inicial a ser investigado através de coleta de dados experimentais, análise dos dados, conclusões e questões para que os conceitos possam ser generalizados.

Algumas aulas foram assistidas pela pesquisadora antes da fase de gravações para corroborar os pressupostos que fundamentam uma aula construtivista e também, para que os alunos se acostumassem com a presença de uma pessoa externa ao cotidiano da sala de aula.

A professora é mestranda em um Programa de Pós-Graduação em Ensino de Química e, na época da coleta de dados, lecionava vinte horas semanais de aulas de Química na Escola B. Atualmente, também é coordenadora pedagógica de uma escola da Prefeitura Municipal de São Paulo com carga horária de 40 horas semanais.

A escola B apresenta laboratório de química integrado à sala de aula, permitindo maior acessibilidade à realização de experimentos. Porém, a escola não dispõe de materiais e reagentes suficientes e necessários para a realização das atividades experimentais e também não tem apoio de um laboratorista.

Todas as atividades experimentais realizadas contaram somente com a dedicação e interesse da professora, que preparava todos os materiais e reagentes previamente e por conta própria.

\subsection{Registro das aulas e transcrição}

Os registros das aulas foram realizados pela própria pesquisadora, procedimento que contribuiu para a melhor compreensão das posteriores transcrições e análise, constando de gravações em áudio e vídeo.

Conforme mencionado anteriormente, a pesquisadora acompanhou algumas aulas antes das gravações nas duas escolas, tanto para evidenciar a presença dos pressupostos que guiam a pesquisa como, também, para que os alunos acostumassem com a presença de uma pessoa externa ao seu cotidiano e com a presença das câmeras. 
A fim de alcançar maior fidedignidade e validação dos resultados, a pesquisadora procurou coletar o maior número de informações a fim de triangular os dados. Desta forma, as falas dos alunos e professores foram registradas, os materiais escritos dos alunos foram fotocopiados, e também realizaram-se notas de campo a fim de registrar por escrito momentos importantes da aula e de acontecimentos que não puderam ser registrados pela câmera, por se tratarem de situações implícitas (ASTOLFI, 1995).

Posterior à coleta, foram realizadas cópias das gravações para poder assisti-las quantas vezes fossem necessárias sem receio de perdê-las ou danificá-las.

A pesquisadora pediu autorização para os pais dos alunos das duas escolas para a realização das gravações e utilização das falas e escrita para a pesquisa. A grande maioria dos alunos entregou as autorizações; das que não foram entregues algumas se referem ao fato de os próprios alunos esquecerem de entregá-las para os pais assinarem. É importante salientar também que, mesmo com a autorização dos pais em mãos, algumas alunas se sentiram incomodadas com a câmera e pediram para não serem filmadas. A fim de não criar um ambiente insatisfatório para a pesquisa e também pela ausência de algumas autorizações, as aulas foram gravadas com a câmera localizada no fundo da sala, mas sempre tomando o cuidado de privilegiar a captura das falas de todos os alunos. Porém, como o ambiente de sala era de constante discussão e diálogo, algumas falas ficaram prejudicadas e sua transcrição tornou-se dificultosa, pois os alunos queriam explicitar suas idéias e acabavam falando juntos em voz alta, contribuindo para a qualidade da pesquisa, mas ao mesmo tempo, dificultando sua transcrição e análise. Desta forma, três gravadores de áudio foram distribuídos pela sala para ajudar na transcrição dos dados caso alguma fala do vídeo fosse prejudicada.

Nas aulas no laboratório os alunos formaram grupos para a realização do experimento. Como a pesquisadora só dispunha de uma câmera para o registro, as falas de um dos grupos de alunos eram registradas em vídeo, e outros dois grupos eram registrados em áudio.

$\mathrm{Na}$ escola $\mathrm{A}$, a pesquisadora acompanhou e registrou a seqüência de aulas sobre o conceito de densidade e temperatura de ebulição das turmas de primeiro ano. Na escola B o conceito desenvolvido pela professora e registrado para a pesquisa foi temperatura de fusão ${ }^{21}$

\footnotetext{
${ }^{21}$ É importante esclarecer que os termos "temperatura de ebulição" e "temperatura de fusão" são atualmente utilizados em detrimento aos termos "ponto de ebulição" e "ponto de fusão", respectivamente. Entretanto, as professoras das escolas A e B utilizaram algumas vezes o termo ponto de ebulição ou ponto de fusão em suas
} 
As transcrições das falas das professoras e dos alunos foram realizadas pela própria pesquisadora, contribuindo para maior fidedignidade e qualidade das transcrições para análise. Mesmo tomando o cuidado de garantir a maior captura possível das falas, em alguns momentos, principalmente durante as atividades experimentais, algumas falas são de difícil entendimento, pois se referem a um momento em que os alunos estão interagindo constantemente e todos querem explicitar suas déias. Porém, muitas dessas falas, de difícil transcrição, foram interpretadas com o auxílio das notas de campo e das anotações realizadas pelos estudantes em sala de aula.

Falas sem teor significativo para a pesquisa, como brincadeiras dos alunos, evocação de atenção pela professora, conversas não relacionadas com o contexto da aula, não foram transcritas, uma vez que não compete aos objetivos da pesquisa. Porém, estas falas não representam um número expressivo, ou seja, ocorrem em momentos nos quais a professora ou um aluno não está falando ou quando se trata de uma brincadeira não referente ao assunto. É evidente que algumas conversas paralelas ocorrem, pois se trata de uma sala mista de trinta a quarenta alunos, porém estas discussões não interferiram nos dados e resultados da pesquisa.

Após as transcrições, foram selecionados episódios de ensino, que são "momentos extraídos de uma aula, onde fica evidente uma situação que se quer investigar", para a análise (CARVALHO et al., 1993). Esses episódios foram selecionados a fim de evidenciar respostas à pergunta da pesquisa, enfatizando a participação dos alunos durante a resolução do problema experimental proposto pelas professoras. Assim, vários episódios foram selecionados e alguns deles estão dispostos na análise de dados. Depois, realizouse a análise dos dados baseando-se nos referenciais teóricos que sustentam a pesquisa.

As transcrições foram totalmente fiéis às falas dos professores e alunos. A digitação das respostas escritas contidas nos materiais fotocopiados dos alunos também foi realizada respeitando totalmente os originais. A análise destes materiais foi realizada uma vez que as respostas escritas são de suma importância para as o processo de ensino e aprendizagem, pois exige e demanda maior esforço cognitivo do escritor (RIVARD; STRAW, 2000). Explicar ou escrever requer que o estudante refine seu pensamento, contribuindo para um maior entendimento dos conceitos estudados, organizando e

explicações; e ainda, o material utilizado pela professora B apresenta algumas questões com o termo ponto de fusão e outras questões com o termo temperatura de fusão. Assim, foram utilizados, no corpo do texto da dissertação, os termos temperatura de ebulição e temperatura de fusão, mas, as falas das professoras foram fielmente transcritas, assim como os materiais disponibilizados aos alunos e suas escritas, mantendo suas autenticidades. 
consolidando suas idéias. Segundo Oliveira e Carvalho (2004), para a escrita ser efetiva, os estudantes precisam apresentar certo conhecimento básico, interagir com seus pares para compartilhar, clarificar e distribuir este conhecimento.

Durante as falas, professores e alunos utilizam expressões como "hum", "óh" ou omitem algumas palavras ou sons, como, por exemplo, não utilizam a palavra "está" e sim "tá". Como isso não pode ser considerado erro, conforme defendem alguns pesquisadores (CARVALHO, 2006), respeitaram-se as falas originais dos interlocutores, mas algumas correções, como a ausência do "r "no final dos verbos, foi realizada.

Utilizaram-se algumas regras para a transcrição baseando-se em Preti (1999), porém é importante relatar que nem todos os sinais sugeridos pelo autor foram empregados nesta dissertação. Alguns sinais mais freqüentes são evidenciados abaixo:

1. Reticências: para marcar qualquer tipo de pausa deve-se empregar reticências no lugar de sinais típicos da língua escrita, como ponto final, vírgula, ponto de exclamação, dois pontos e vírgula. $O$ único sinal mantido é o de interrogação

2. ( ) para hipótese do que se ouviu

3. (( )) para a inserção de comentários do pesquisador

4. Letras maiúsculas para entonação enfática

$\mathrm{Na}$ transcrição, os alunos foram representados pelas letras Al seguido de um número (Al1, Al2) referente à sua identificação determinada pela pesquisadora; quando não houve a possibilidade de identificar o aluno, utilizou-se somente o termo Al. Assim o aluno Al1 ou Al2 de uma sala será sempre o mesmo aluno designado pela pesquisadora durante toda a seqüência de aulas de uma série e escola. As falas dos professores são representadas pela letra $P$.

As transcrições são apresentadas durante a dissertação conforme mostra o quadro a seguir:

\begin{tabular}{|c|c|c|}
\hline Tempo & Discurso & Análise \\
\hline & & \\
\hline
\end{tabular}

A primeira coluna se refere ao tempo real da aula. Considerou-se este item na análise dos dados a fim de se verificar o tempo disponibilizado pela professora para os alunos responderem à questão proposta. Na segunda coluna encontram-se as 
transcrições das falas dos alunos e da professora, e na terceira coluna a análise das falas com os níveis relacionados.

Algumas falas não apresentam análise, pois não contêm teor significativo para classificação.

Quando a classificação de alguma fala ou questão pudesse gerar discordância entre dois níveis, ou seja, se houvesse dificuldade em classificar em um nível mais alto ou mais baixo de cognição, escolheu-se por classificá-la no nível mais baixo, a fim de evitar subjetivismos.

É importante esclarecer que o número de respostas emitidas pelos alunos não está relacionada com o número de questões propostas pela professora, pois não necessariamente os alunos responderam a todas as questões propostas e também algumas vezes fez-se necessária uma re-elaboração da questão pela professora para melhor entendimento pelos alunos.

Algumas falas apresentam ao lado uma letra minúscula entre parênteses, por exemplo, (a). Estas letras se referem a uma seqüência de falas que farão parte de uma única análise, uma vez que se trata de uma seqüência que evidencia um raciocínio elaborado por um ou vários alunos ou raciocínio que necessita do auxílio e intervenção da professora para se tornar mais elaborado. Desta forma, serão apresentadas as letras referentes ao raciocínio ao lado da transcrição e também na coluna de análise para que fique evidente a seqüência de raciocínio manifestada pelo aluno ou alunos.

\subsection{A seqüência de aulas}

Serão apresentadas para análise as seguintes seqüências de aulas:

\section{Escola A :}

Conceito de densidade: Primeira Série I e Primeira Série II

Conceito de temperatura de ebulição: Primeira Série I

\section{Escola B:}

Conceito de temperatura de fusão: Primeira Série A 
A seqüência de aulas sobre o conceito temperatura de ebulição da Primeira Série II da Escola A não será apresentada, pois como a análise do conceito de densidade será discutida para as duas turmas, é possível analisar e fazer inferências sobre as aulas da professora A com diferentes alunos participantes. Como nas duas escolas a proposta das professoras são similares quanto aos objetivos e finalidades do processo de ensino e aprendizagem, assim como as propostas dos materiais utilizados por elas, foram então analisadas, uma turma da escola $A$ sobre o conceito de temperatura de ebulição e a turma da escola $B$ sobre o conceito de temperatura de fusão, não com o objetivo de realizar comparações, mas de verificar algumas semelhanças ou discrepâncias das duas escolas.

\subsubsection{Escola A}

\section{Primeira Série I}

\section{Experimento: Densidade}

Como já relatado anteriormente, não se determinou qual conteúdo químico seria investigado, a pesquisadora gravou e analisou as aulas do segundo semestre de $2006 \mathrm{sem}$ nenhuma interferência metodológica.

Foram gravadas e analisadas quatro aulas de cinqüenta minutos cada, sobre 0 conceito de densidade, as quais podem ser separadas em três momentos:

- pré-laboratório: experimentos demonstrativos realizados pela professora com o objetivo de levantar as idéias prévias dos alunos, dialogar, promover a proposição de hipóteses para a construção de conteúdos essenciais para a formação do conceito densidade, como por exemplo massa e volume;

- laboratório : momento em que os alunos vão à bancada realizar o experimento em grupos ;

- pós-laboratório: discussão com toda a sala para a conceituação final e possíveis generalizações.

O pré-laboratório teve a duração de duas aulas de cinqüenta minutos e também utilizou alguns minutos de uma terceira aula. $O$ restante da terceira aula foi utilizado para a realização do experimento e na quarta aula os alunos e a professora discutiram os dados obtidos, responderam a questões e conceituaram densidade.

Entre a terceira e quarta aula houve uma aula utilizada para aqueles alunos que não conseguiram terminar o experimento anteriormente, porém esta não foi considerada, 
mesmo estando registrada, pelo fato de sua transcrição não apresentar conteúdo significativo para a análise. Os alunos apenas terminaram 0 experimento sem

questionamentos ou argumentações que contribuíssem para os dados da pesquisa. É importante relatar que as discussões dos resultados foram realizadas após todos os alunos terem terminado o experimento.

Durante a realização do experimento no laboratório, a professora entregou aos alunos uma folha com instruções para a realização da atividade. Esta apresentava também questões escritas que exigiam o raciocínio e o diálogo dos pares para sua resolução.

$\mathrm{Na}$ etapa final da conceituação, a professora apresentou novamente algumas questões para o fechamento do assunto. Dentre essas questões, algumas exigiam apenas resolução algorítmica e outras exigiam habilidades cognitivas como análise de variáveis conforme será discutido na análise dos dados.

\section{Experimento : Temperatura de ebulição}

Foram gravadas 5 aulas de cinqüenta minutos cada sobre o conceito de temperatura de ebulição, e que podem ser separados da seguinte forma:

- Pré-laboratório: a professora discute com os alunos alguns conceitos essenciais para o desenvolvimento do problema proposto, os alunos propõem as hipóteses para investigação e se reúnem em grupos para elaborar o procedimento experimental;

- Laboratório: os alunos vão para o laboratório executar o experimento, analisar os dados obtidos e inferir suas conclusões;

- Pós-laboratório: discussão com toda a sala para a conceituação final e possíveis generalizações.

O pré-laboratório teve duração de uma aula. Os primeiros vinte e sete minutos da aula foram utilizados para discussão oral sobre o problema a ser investigado. No restante da aula, os alunos se agruparam para elaborar o procedimento experimental e, na segunda aula, realizaram o experimento.

Entre a segunda aula (laboratório) e a quarta aula (pós-laboratório) houve uma terceira aula utilizada por aqueles alunos que não terminaram o experimento ou as discussões em grupo na aula anterior. Entretanto uma análise prévia do conteúdo desta gravação não mostrou resultados significativos para a pesquisa, e não serão considerados. 
$\mathrm{Na}$ quarta aula (pós-laboratório), a professora distribuiu para os alunos um questionário referente à atividade realizada e discutiu os dados obtidos e as conclusões dos grupos. Em uma quinta aula, após o pós-laboratório, a professora refaz um dos experimentos (variável: pressão) e rediscute o conceito não compreendido pelos alunos. Nesta aula, a professora também pede para que os alunos respondam a um questionário por escrito.

Mesmo se tratando de atividades experimentais investigativas, esta se diferencia um pouco da primeira, densidade, pois os próprios alunos propõem as hipóteses para a investigação, elaboram o procedimento experimental, realizam o experimento e analisam os seus dados fundamentados em suas hipóteses. Esta atividade é denominada por Carvalho et al. (1999) como Laboratório Aberto. A autora utiliza este termo para definir uma atividade experimental investigativa na qual o aluno se envolve na resolução de um problema, e se mobiliza a procura de uma metodologia para a sua resolução. Esta atividade pode ser dividida em seis momentos segundo a autora: proposta do trabalho, levantamento de hipóteses, elaboração do plano de trabalho, montagem dos arranjos experimentais e coleta de dados, análise dos dados e conclusão.

Assim, a seqüência de aulas sobre o conceito de temperatura de ebulição apresenta os seis momentos propostos por Carvalho et al. (1999), uma vez que a professora propôs um problema para os alunos na primeira aula e eles expuseram suas hipóteses e elaboraram um plano de trabalho contendo os materiais, procedimento e previsões. A etapa que poderia ser questionada nessa proposta é a montagem dos arranjos, uma vez que não foi realizada pelos alunos, mas pela professora e auxiliar técnico, a fim de minimizar o tempo que poderia ser utilizado em etapas como coleta e análise dos dados. Entretanto, a manipulação e coleta dos dados foram realizadas pelos próprios alunos, não comprometendo a efetividade e as características da atividade.

As outras etapas sugeridas por Carvalho et al. (1999) foram realizadas na segunda, quarta e quinta aulas.

Assim, a não participação dos alunos na montagem dos arranjos não descaracterizou a atividade, que pode ser considerada um Laboratório Aberto, pois habilidades como manipulação e organização que seriam manifestadas ou desenvolvidas em parte desta etapa puderam ser evidenciadas em seu restante (coleta de dados) e em outras. 


\section{Primeira Série II}

Experimento densidade: A seqüência de atividade ocorreu semelhantemente à outra série, porém nesta série a professora utilizou uma aula a mais durante o prélaboratório. Portanto, no total, foram gravadas e analisadas 5 aulas. Maiores detalhamentos serão discutidos na seção da análise.

\subsubsection{Escola B}

\section{Primeira Série A}

\section{Experimento: Temperatura de Fusão}

O objetivo da seqüência de aulas da professora da Escola B era construir conhecimentos que permitissem aos alunos identificar características próprias de um material. A professora, anteriormente ao conceito de temperatura de fusão, o qual será discutido nesta dissertação, havia discutido temperatura de ebulição também com o auxílio de uma seqüência de aulas e experimento investigativo; porém, essas aulas não foram acompanhadas pela pesquisadora, pois a autorização das gravações aconteceu durante essas aulas. Como o objetivo era analisar a seqüência de aulas para a construção dos conceitos, a pesquisadora preferiu gravar a seqüência de aulas para o desenvolvimento do conceito posterior, temperatura de fusão.

O propósito inicial da pesquisa era acompanhar também a seqüência de aulas sobre densidade, posterior à temperatura de fusão, porém por motivos burocráticos da escola e insatisfação manifestada pelos alunos com a presença da câmera, a pesquisadora não pode realizar as gravações.

As aulas da Escola B tinham duração de sessenta minutos. Foram utilizadas cinco aulas para a construção do conceito temperatura de fusão, as quais podem ser separadas nos seguintes momentos:

- execução do experimento pelos alunos

- elaboração dos gráficos

- análise dos dados e conclusões

- questões para discussão

A primeira aula foi utilizada para a realização do experimento. Alguns grupos realizaram o aquecimento e resfriamento da naftalina e outros da parafina. $\mathrm{Na}$ 
segunda aula, a professora utilizou aproximadamente quinze minutos para explicar a construção do gráfico, e no restante da aula os alunos construíram os gráficos de aquecimento e resfriamento do material investigado.

$\mathrm{Na}$ terceira aula, a professora, seguindo a proposta do material, discute com os alunos as questões sobre a análise de dados e conclusões. Alguns minutos desta terceira aula, aproximadamente dez, são destinados para que os alunos respondam às questões em sala de aula.

$\mathrm{Na}$ quarta aula, os alunos se agruparam para responder às questões de discussão propostas no material. Após aproximadamente trinta minutos, a professora realizou a discussão com toda a sala.

Entre a terceira e quarta aula, houve uma aula, na qual a professora realizou novamente os experimentos de aquecimento e resfriamento da naftalina, pois a professora verificou, após receber os gráficos construídos pelos alunos, que os resultados não concordavam com os valores esperados. Os gráficos não apresentavam as características de uma substância, ou seja, uma temperatura de fusão, mas sim uma faixa de temperatura, e também, as temperaturas obtidas pelos alunos não eram condizentes com a literatura. A professora, então, realizou novamente o experimento e coletou os dados para construir com os alunos um novo gráfico.

A professora atribuiu o erro talvez ao fato de a naftalina não estar bem triturada ou talvez pelos alunos terem retirado o termômetro do tubo de ensaio com a amostra para efetuar a leitura da temperatura.

Essa aula não pôde ser registrada por motivos de saúde da pesquisadora, porém, a ausência deste registro parece não ter dificultado a análise dos dados, pois todos os materiais elaborados pelos alunos e entregues para a professora foram fotocopiados pela pesquisadora a utilizados na pesquisa. Entretanto, é importante esclarecer que as filmagens são dados de suma importância para a compreensão do processo de ensino e aprendizagem, uma vez que capturam as falas e situações algumas vezes implícitas na sala de aula. Mas, diante da impossibilidade desta coleta é importante agrupar e analisar todos os dados disponíveis a procura de uma resposta para o problema investigado. 


\subsection{Categorias de análise}

A pesquisa qualitativa se caracteriza por apresentar aspectos descritivos em sua análise. Os dados qualitativos coletados por pesquisadores estão na forma de imagens ou palavras, muito mais do que na forma de números. Segundo Bogdan e Biklen (1994), os resultados escritos da investigação apresentam citações baseadas nos dados que fortalecem a sua análise, sempre considerando toda a riqueza dos dados, contanto, respeitando a forma na qual foram transcritos ou registrados. Ainda, segundo os autores, não se recolhem dados ou provas com o objetivo de confirmar ou infirmar hipóteses constituídas previamente; ao invés disso, as abstrações são construídas à medida em que os dados particulares que foram recolhidos vão se agrupando.

Desta forma, para a análise dos dados qualitativos, há a necessidade de se realizar uma categorização desses dados.

Criar categorias não é algo fácil e exige cautela e conhecimento sobre o que se quer obter com essas categorias. As categorias elaboradas para esta investigação se enquadram no que Moraes (2005) define como categorias iniciais ou a priori, na qual o pesquisador deriva suas categorias de seus pressupostos teóricos, sejam eles implícitos ou explícitos; assim, as categorias já estão definidas antes de encaminhar a pesquisa. As investigações que se baseiam neste processo são mais fáceis de se conduzir, uma vez que o pesquisador inicia a coleta de dados com um olhar mais centrado no que buscar, podendo cometer menos erros metodológicos ou de coleta de dados. Porém, esse olhar muito centrado nos objetivos pode impedir que o pesquisador amplie seu campo de investigação e enriqueça a sua análise.

A escolha por se trabalhar com as categorias a priori deve-se ao fato de a pesquisa estar direcionada à análise de habilidades cognitivas e estarem fundamentadas em pressupostos da literatura referente, fato que facilita e não prejudica a elaboração de categorias prévias a coleta dos dados.

O processo de elaboração das categorias para esta pesquisa foi baseado nos objetivos conceituais e cognitivos propostos para as atividades experimentais investigativas em um contexto construtivista.

Duas categorizações foram utilizadas para a compreensão no nível de habilidades cognitivas desenvolvidas pelos alunos. A primeira se refere às questões propostas pelo professor e a segunda às respostas elaboradas pelos alunos para essas questões. 


\section{Categoria 1: as questões propostas pelo professor}

A análise das perguntas dos professores é de fundamental importância, pois para que 0 aluno se engaje efetivamente no processo de aprendizagem é necessário que a tarefa proposta seja desafiadora e significativa. Não se pode esperar que o aluno desenvolva uma resposta de alto nível cognitivo se não for estimulado para isto. Yarden et al. (2001), em uma pesquisa realizada para identificar o nível cognitivo das perguntas elaboradas por alunos, verificou que o nível cognitivo de certas questões feitas pelos estudantes é determinado pelo tipo de questão que é requerido pelo professor. Essas afirmações fortalecem a importância da mediação do professor na construção do conhecimento pelos alunos.

Adaptou-se o critério de categorias desenvolvido por Shepardison e Pizzini (1991), que investigaram o nível de exigência cognitiva requerido pelas questões propostas em livros didáticos do ensino médio de química. Em um trabalho recente, Malaver et al. (2005), utilizam categorias também adaptadas de Shepardison e Pizzini para analisar livros universitários de Química Geral.

Baseando-se nessas pesquisas, os níveis de questões orais e escritas propostas pela professora foram categorizadas conforme mostra a tabela 3.1 :

Tabela 3.1- Nível de cognição das questões propostas para os alunos

\begin{tabular}{|c|l|}
\hline Nível & \multicolumn{1}{|c|}{ Descrição } \\
\hline P1 & $\begin{array}{l}\text { Requer que o estudante somente recorde uma informação partindo dos dados } \\
\text { obtidos. }\end{array}$ \\
\hline P2 & $\begin{array}{l}\text { Requer que o estudante desenvolva atividades como seqüenciar, comparar, } \\
\text { contrastar, aplicar leis e conceitos para a resolução do problema. }\end{array}$ \\
\hline P3 & $\begin{array}{l}\text { Requer que o estudante utilize os dados obtidos para propor hipóteses, fazer } \\
\text { inferências, avaliar condições e generalizar. }\end{array}$ \\
\hline
\end{tabular}

Malaver et al. (2005) não utilizam as habilidades cognitivas de alta ou baixa ordem para dimensionar as categorias, porém Shepardison e Pizzini denominam os níveis de questão como: "input", aquelas que requerem do estudante somente recordar uma informação; "processing", questões nas quais os estudantes fazem relações entre os dados, necessitando relacionar, comparar, contrastar, classificar; e por último, as denominadas "output", questões que exigem do estudante utilizar não somente os dados para sua resolução, mas hipotetizar, generalizar, criar e avaliar.

No contexto desta pesquisa os níveis cognitivos das questões propostas pelas professoras serão denominados apenas por nível P1, nível P2 ou nível P3. 


\section{Categoria 2: Nível de cognição das respostas elaboradas pelos alunos}

As categorias de análise foram criadas com o objetivo de privilegiar algumas habilidades cognitivas, como elaboração de hipóteses, análise das variáveis, processos de controle, entre outras, declaradas por muitos autores e pesquisadores, conforme já discutido anteriormente, necessárias para o desenvolvimento conceitual e cognitivo dos alunos.

Baseando-se nos pressupostos de Zoller (2001, 2002, 2007), as categorias elaboradas foram delineadas considerando as habilidades cognitivas inferidas a partir das respostas dadas pelos alunos durante a atividade experimental, pré e pós-laboratório. As categorias foram classificadas como algorítmicas (ALG), de baixa ordem (LOCS) ${ }^{22}$ ou de alta ordem (HOCS) ${ }^{23}$ e são mostrada na tabela 3.2:

Tabela 3.2 - Nível cognitivo das respostas dos alunos

\begin{tabular}{|c|c|}
\hline Nível & Categoria de resposta ALG \\
\hline N1 & $\begin{array}{l}\text { - } \quad \text { Não reconhece a situação problema. } \\
\text { - } \quad \text { Limita-se a expor um dado relembrado. } \\
\text { - } \quad \text { Retêm-se a aplicação de fórmulas ou conceitos }\end{array}$ \\
\hline Nível & Categoria de resposta LOCS \\
\hline $\mathrm{N} 2$ & $\begin{array}{l}\text { - } \quad \text { Reconhece a situação problemática e identifica o que deve ser buscado. } \\
\text { - Não identifica variáveis } \\
\text { - Não estabelece processos de controle para a seleção das informações. } \\
\text { - Não justifica as respostas de acordo com os conceitos exigidos }\end{array}$ \\
\hline N3 & $\begin{array}{l}\text { - Explica a resolução do problema utilizando conceitos já conhecidos ou relembrados } \\
\text { (resoluções não fundamentadas, por tentativa) e quando necessário representa o problema } \\
\text { com fórmulas ou equações. } \\
\text { - } \quad \text { Identifica e estabelece processos de controle para a seleção das informações } \\
\text { - Identifica as variáveis, podendo não compreender seus significados conceituais. }\end{array}$ \\
\hline Nível & Categoria de resposta HOCS \\
\hline N4 & $\begin{array}{l}\text { - Seleciona as informações relevantes. } \\
\text { - } \quad \text { Analisa ou avalia as variáveis ou relações causais entre os elementos do problema. } \\
\text { - Sugere as possíveis soluções do problema ou relações causais entre os elementos do } \\
\text { problema. } \\
\text { - Exibe capacidade de elaboração de hipóteses }\end{array}$ \\
\hline N5 & - Aborda ou generaliza o problema em outros contextos ou condições iniciais \\
\hline
\end{tabular}

As categorias e suas características foram dimensionadas com o objetivo de analisar quais habilidades cognitivas os alunos parecem utilizar na resolução dos problemas experimentais propostos. Foram propostas três categorias principais denominadas ALG, LOCS e HOCS. A categoria ALG é compostas pelo nível N1; a

\footnotetext{
${ }^{22}$ Lower Order Cognitive Skills

${ }^{23}$ Higher Order Cognitive Skills
} 
categoria LOCS pelos níveis N2 e N3 e a categoria LOCS pelos níveis N4 e N5. As categorias ALG e LOCS para Zoller (2002, 2007), podem ser agrupadas como uma única categoria ou, então, a categoria ALG pode ser considerada como uma subcategoria das LOCS, pois ambas apresentam respostas algorítmicas e evocação memorística. Entretanto, a escolha desta pesquisa para a divisão em duas categorias se refere ao fato de algumas respostas dos alunos apresentarem não somente dados algorítmicos e memorização, mas também, devido algumas vezes, a não compreensão do problema pelo aluno. A divisão em ALG e LOCS pode permitir que a categorização das respostas apresente maior delimitação, contribuindo para uma maior facilidade e fidedignidade na categorização e também por admitir que respostas com diferentes demandas cognitivas sejam classificadas em categorias distintas. O mesmo raciocínio foi utilizado ao atribuir a subdivisão da categoria LOCS em N2 e N3 e a categoria HOCS em N4 e N5, contribuindo assim, para uma melhor compreensão dos processos cognitivos e habilidades envolvidos e manifestados na resolução de um problema.

Assim, quando um aluno não compreende o problema ou utiliza para sua resolução apenas dados memorizados, considera-se que esse aluno evocou dados algorítmicos, elaborando pouco ou nenhum raciocínio lógico para sua resolução, sendo suas respostas dimensionadas na categoria N1 (ALG). Quando o aluno reconhece a situação problemática e identifica variáveis mas ainda apresenta pouca demanda cognitiva em suas respostas, considera-se que este aluno utilizou apenas habilidades cognitivas de baixa ordem, e suas respostas são então categorizadas como N2 (LOCS).

A categoria N3 (LOCS) já começa a apresentar características para uma possível evolução para o N4 (HOCS). Mesmo ainda apresentando habilidades que exigem a aplicação de conhecimentos simples a situações conhecidas, os alunos já podem começar a estabelecer processos de controle para a resolução do problema, se aproximando do nível N4 (HOCS).

Por fim, quando o aluno apresenta respostas que envolvem elaboração de hipóteses, análise de variáveis e relações causais, ou seja, pensamentos mais complexos para a resolução de um problema, considera-se que este aluno utilizou habilidades cognitivas de alta ordem, e suas respostas são categorizadas como N4 (HOCS). Um nível maior de complexidade é considerado quando o aluno consegue ultrapassar a situação atual e abordá-la em outros contextos, apresentando as características do N5 (HOCS) de habilidades cognitivas. 
Entretanto, a inclusão de uma dada habilidade cognitiva pode variar de autor para autor, ou seja, a categoria N3 definida nesta pesquisa como LOCS, poderia ser classificada por outro autor como HOCS.

Outra questão a ser considerada está relacionada com a definição e descrição utilizada para incluir elementos em cada categoria. As categorias e suas características, mesmo sendo previamente elaboradas, algumas vezes precisam ser redimensionadas conforme os dados vão sendo analisados. Dessa forma, as categorias apresentadas na presente pesquisa passaram por processos de redimensionamento para melhor se adequar aos objetivos de investigação. Conforme argumenta Moraes (2005), as categorias vão se aperfeiçoando ao longo da análise, para que no final do processo apresentem significados claros para a classificação dos enunciados, entretanto, mesmo produzindo uma definição cuidadosa dos critérios de classificação para as categorias, o processo de categorização nunca é inteiramente objetivo, podendo dar margem para dúvidas e imprecisões.

Como realizar a relação teoria/dados empíricos não se trata de uma etapa simples da análise de dados da pesquisa, a pesquisadora contou com o apoio de colegas pesquisadores para classificar alguns dados transcritos nas categorias elaboradas. Essa apresentação, categorização e discussão dos dados com um grupo contribuiu para uma maior fidedignidade e validade dos resultados.

Foram realizados três encontros com duração de duas horas cada com um grupo de discussão formado por cinco colaboradores, entre eles mestres e mestrandos. No primeiro encontro a pesquisadora apresentou para o grupo o problema a ser investigado e discutiu as suas categorias e suas características. Neste mesmo encontro os colegas levaram para suas casas parte das transcrições de uma aula de uma das escolas investigadas para que as categorizassem segundo os critérios propostos. No segundo encontro, cada pesquisador argumentou a classificação realizada para determinada questão e, quando os resultados eram contraditórios para um ou mais pesquisadores, o grupo discutia suas idéias e sugeriam alterações no instrumento de análise. Uma segunda categorização de outros dados transcritos foi feita pelos pesquisadores a fim de verificar se 0 instrumento ainda precisava de ajustes, entretanto, poucas modificações precisaram ser realizadas. No terceiro encontro nova discussão foi realizada e o grupo encontrou uma relação de $78 \%$ de concordância nas classificações. É importante 
salientar que este grupo já havia participado de outras discussões da mesma natureza com outros colegas. 


\section{$4 \quad$ Análise dos dados e Resultados}

Após assistir por diversas vezes as gravações e realizar as transcrições, partiu-se então para a análise dos dados.

As falas das professoras foram analisadas de acordo com os critérios apontados na tabela 3.1 e as dos alunos foram analisadas conforme as categorias mostradas na tabela 3.2. Para isso, houve a necessidade de interpretar as falas dos alunos e da professora de forma a abstrair o seu conteúdo, algumas vezes explícito outras vezes implícito, para analisar a freqüência com que cada categoria de habilidades cognitivas surge durante as discussões.

A análise do momento da atividade experimental foi realizada holisticamente, ou seja, não se analisou isoladamente cada fala dos alunos, pois o conjunto das falas e seu estudo global revelaram maior significado com relação às habilidades cognitivas do que quando avaliadas pontualmente. Algumas falas revelam muito mais interação do que cognição, porém a interação não será tratada nesta pesquisa.

Algumas falas não foram consideradas para análise por não apresentarem conteúdo significativo para sua categorização e inclusão nos resultados da pesquisa. Por fim, as frases e raciocínios cognitivos foram qualitativamente analisados e dispostos nas categorias definidas. São considerados neste trabalho, a freqüência com que cada categoria surge no decorrer da construção dos conceitos desenvolvidos e suas relações com a atividade experimental investigativa.

Para facilitar a visualização, a análise dos dados será disposta em gráficos. A apresentação dos dados na forma numérica não descaracteriza a metodologia qualitativa, pois os números apenas ajudarão a explicar a dimensão qualitativa (ANDRÉ, 2000). Toda a análise está baseada na metodologia qualitativa e os números apenas evidenciam a interpretação descritiva e qualitativa da pesquisadora durante a seqüência de aulas.

A análise dos dados da Escola A, para as duas séries, sobre o conceito de densidade está dividida em três etapas: a primeira se refere às questões propostas pela professora e às respostas fornecidas pelos alunos nas três primeiras aulas de discussão pré-laboratório, em que a professora discutiu os conceitos de massa e volume e foi elaborado o conceito de densidade; a segunda etapa de análise diz respeito ao momento de realização dos experimentos pelos estudantes, na terceira aula; e o terceiro momento, refere-se à discussão final com toda a sala e retomada do conceito. 
Foram analisadas também as respostas escritas dos alunos durante a atividade experimental e no fechamento do conceito.

A análise dos dados para o conceito de temperatura de ebulição desenvolvido pela professora da Escola A, para os alunos da primeira série I, está organizada da seguinte forma: a primeira etapa se refere às questões propostas pela professora e às respostas dadas pelos alunos e elaboração dos planejamentos experimentais pelos alunos na primeira aula. A segunda etapa se refere à realização do experimento pelos alunos e discussão dos resultados e a terceira etapa se refere à discussão e comunicação dos resultados com toda a sala. Durante as etapas serão expostas partes dos planejamentos e relatórios desenvolvidos pelos alunos.

Para a Escola $B$, a análise está disposta conforme a seqüência seguida pela professora B, ou seja, conforme os tópicos se apresentam no material. O primeiro tópico se refere à execução do experimento e o segundo se refere à elaboração dos gráficos. $\mathrm{O}$ terceiro tópico diz respeito à análise de dados e conclusões, e nesta etapa a professora discute algumas questões contidas no material. As respostas dos alunos para essas questões serão analisadas dependendo da natureza da questão propostas pela professora, ou seja, em algumas questões a professora faz uma discussão que gera participação dos alunos. Assim, as falas do professor e as respostas dos alunos geradas durante essa discussão foram analisadas como questões orais. Porém, em algumas questões a professora não faz uma discussão mais aprofundada do assunto, assim, a fim de não perder dados substanciais para a pesquisa, foram então analisadas, as respostas escritas dos alunos, uma vez que a professora pediu para que os alunos entregassem por escrito os gráficos e as respostas de todas as questões propostas.

Algumas questões foram analisadas tanto na forma oral como na escrita, pois são questões que geraram discussões em sala e precisavam de uma elaboração e síntese por parte dos alunos.

Essa mesma situação aconteceu na quarta etapa da análise na qual algumas questões para discussão são propostas. Assim, as respostas escritas elaboradas pelos alunos, referentes às quatro etapas, encontram-se em uma seção à parte, denominada questões escritas.

Serão apresentados alguns trechos das falas e das respostas escritas dos alunos e das questões propostas pela professora durante a análise dos dados. 


\subsection{Escola A}

\subsubsection{Experimento: Densidade}

\subsubsection{Primeira Série I}

\section{Primeira aula}

O objetivo da seqüência de aulas, como já mencionado, era conceituar densidade em um ambiente que privilegiasse a participação do aluno, ou seja, em um contexto construtivista e investigativo. Na primeira aula, com duração de cinqüenta minutos, a professora recordou rapidamente com os alunos o experimento de Lavoisier ${ }^{24}$. Partindo desses conhecimentos, trabalhados no bimestre anterior, a professora desafiou os alunos perguntando como Lavoisier sabia que o produto obtido em seu experimento era realmente água. Assim, a professora tinha como propósito abordar os conceitos de densidade, temperatura de ebulição e fusão com a seguinte questão: "Com podemos identificar um material?".

Utilizando uma balança e massas idênticas de algodão e chumbo, a professora mostrou que massas iguais de diferentes materiais podem possuir volumes diferentes. Essa estratégia é de suma importância para a construção do conceito de densidade, pois muitos alunos confundem massa, peso e volume.

A professora procurou, com questões que exigem comparação e avaliação de condições, que os alunos explicitassem suas idéias sobre o que evidenciaram quando o algodão e o chumbo foram pesados e se era possível identificá-los, conforme mostra a seqüência de falas:

\begin{tabular}{|l|l|l|}
\hline \multicolumn{1}{|c|}{ Tempo } & \multicolumn{1}{|c|}{ Discurso } & Análise \\
\hline $05: 20$ & $\begin{array}{l}\text { P: Olha só...as massas são muito próximas... não são iguais mas } \\
\text { são muito próximas...é possível identificar o chumbo e o algodão } \\
\text { pela massa? ((houve aqui, uma pequena diferença na medidas que } \\
\text { não causou nenhuma interferência nos objetivos)) }\end{array}$ & P3 \\
\hline $05: 28$ & Al: É & \\
\hline $05: 30$ & P: É por quê? & \\
\hline $05: 34$ & Al: Porque o chumbo é mais pesado (g) & \\
\hline $05: 35$ & $\begin{array}{l}\text { P: O chumbo é mais pesado } \\
\text { P: O chumbo é mais pesado aqui? }\end{array}$ & \\
\hline $05: 37$ & Al: Não o chumbo é menor que... (h) & \\
\hline $05: 43$ & P: Neste caso o chumbo é mais leve e aí? \\
\hline
\end{tabular}

\footnotetext{
${ }^{24}$ Lavoisier observou que na combustão de gás oxigênio e gás hidrogênio em um balão havia a formação de um líquido. Ao determinar as massas dos gases iniciais e da substância obtida no final do experimento, Lavoisier identificou o líquido como sendo água.
} 


\begin{tabular}{|l|l|l|}
\hline $05: 47$ & Al: É que a massa dele está mais concentrada (i) & $\begin{array}{l}\text { N4:Sugere } \\
\text { possível solução, } \\
\text { elabora hipótese. } \\
(\mathrm{g}, \mathrm{h}, \mathrm{i})\end{array}$ \\
\hline
\end{tabular}

Neste episódio, os alunos começam a elaborar uma hipótese para responder porque, mesmo apresentando a mesma massa, os materiais apresentam volumes diferentes. Ainda desconhecendo o conceito densidade, os alunos tentam explicar que o fato é devido à massa do chumbo estar "mais concentrada".

Em seguida, a professora passou entre os alunos três tubos de ensaio, contendo o mesmo volume de mercúrio, água e alumínio ${ }^{25}$, para que os alunos verificassem a diferença das massas, sentindo os seus pesos.

\begin{tabular}{|l|l|l|}
\hline \multicolumn{1}{|c|}{ Tempo } & \multicolumn{1}{|c|}{ Discurso } & \multicolumn{1}{|c|}{ Análise } \\
\hline $21: 23$ & $\begin{array}{l}\text { P: Gente...então oh..atenção ..pessoal } \\
\text { P: Para quem já viu os frasquinhos } \\
\text { P: } \text { O que é diferente entre os frasquinhos? }\end{array}$ & P2 \\
\hline $21: 27$ & Al: peso & $\mathrm{N} 2$ \\
\hline $21: 32$ & P: O peso...o que é igual ou muito semelhante? & P2 \\
\hline $21: 35$ & Al: A quantidade & N2 \\
\hline $21: 36$ & P: A massa? & P2 \\
\hline $21: 40$ & Al: Volume & N2 \\
\hline $21: 49$ & $\begin{array}{l}\text { P: O volume...o que a gente tem aqui... aproximadamente volumes } \\
\text { iguais e o que é diferente? }\end{array}$ & P2 \\
\hline $21: 51$ & Al: Peso & N2 \\
\hline $22: 10$ & $\begin{array}{l}\text { P: Peso e a... massa } \\
\text { P: Então volto a perguntar a vocês...eu perguntei da massa...dá } \\
\text { para identificar um material pesando o material...sim ou não? }\end{array}$ & P3 \\
\hline $22: 15$ & Al: Não & \\
\hline $22: 26$ & $\begin{array}{l}\text { P: Vamos lá...vamos pensar juntos de novo...o que é massa e o } \\
\text { que é volume? }\end{array}$ & \\
\hline
\end{tabular}

Neste momento, a professora discute com os alunos a diferença entre massa, peso e volume e volta a perguntar se é possível identificar uma material pelo volume:

\begin{tabular}{|l|l|l|}
\hline \multicolumn{1}{|c|}{ Tempo } & \multicolumn{1}{|c|}{ Discurso } & \multicolumn{1}{c|}{ Análise } \\
\hline $37: 31$ & $\begin{array}{l}\text { P: Então volta a pergunta...dá para identificar um material pelo } \\
\text { volume? }\end{array}$ & P3 \\
\hline $37: 33$ & Al: Não & $\mathrm{N} 2$ \\
\hline $37: 38$ & P: Dá para identificar pela massa? & $\mathrm{N} 4$ \\
\hline $37: 40$ & Al 1: Depende se eles tiverem o mesmo volume dá & \\
\hline $37: 45$ & $\begin{array}{l}\text { P: } \text { Então se a gente tiver o mesmo volume } \\
\text { P: Então pela massa eu consigo identificar...vamos pensar nessa } \\
\text { hipótese }\end{array}$ & \\
\hline
\end{tabular}

\footnotetext{
${ }^{25} \mathrm{O}$ metal alumínio encontrava-se pulverizado.
} 
No tempo 37:40, o aluno propõe uma hipótese, mesmo ainda não conhecendo o conceito de densidade, tentando resolver o problema por exclusão, ou seja, conhecendo um dos valores seria possível determinar a incógnita.

A professora, então, determina a massa de uma proveta vazia e depois com $50 \mathrm{~mL}$ de água, com o objetivo de construir o conceito de massa e volume:

\begin{tabular}{|c|c|c|}
\hline Tempo & Discurso & Análise \\
\hline 42:01 & $\begin{array}{l}\text { P: Então volta a pergunta... dá para identificar um material pelo } \\
\text { volume? }\end{array}$ & N3 \\
\hline 42:03 & Al: Não & $\mathrm{N} 2$ \\
\hline 42:13 & P: Qual que é a massa de água que está na proveta? & P2 \\
\hline 42:17 & Al: Aproximadamente cinqüenta $\mathrm{mL}$ & \\
\hline $42: 19$ & P: Oh a pergunta que eu fiz & \\
\hline 42:23 & Al: Cinqüenta e três vírgula dez & \\
\hline 42:26 & Al:Cento e setenta e três vírgula zero três & \\
\hline $42: 40$ & $\begin{array}{l}\text { P: Devagar vamos pensar... eu vou repetir a pergunta } \\
\text { P: Qual a massa... MASSA de água que está na proveta? ((a } \\
\text { professora fala massa em tom enfático)) }\end{array}$ & \\
\hline $42: 46$ & Al: Cento e sessenta e três & $\mathrm{N} 2$ \\
\hline $42: 46$ & $\begin{array}{l}\text { P: Cento e sessenta e três...essa é a massa de água? } \\
\text { P: Quanto Al? }\end{array}$ & \\
\hline 42:54 & Al: Cento e sessenta e três vírgula zero três menos cinqüenta $\mathrm{mL}$ & N2 \\
\hline 42:59 & P:Menos cinqüenta $\mathrm{mL}$ ? & \\
\hline 43:05 & Al 4: Quarenta e seis vírgula trinta e nove & N3 \\
\hline 43:09 & P: Al4 que conta você fez? & \\
\hline 43:11 & $\begin{array}{l}\text { Al4: Cento e sessenta e três vírgula zero três menos cento e } \\
\text { dezesseis vírgula sessenta e quatro ...é a massa da água }\end{array}$ & N4 \\
\hline 43:34 & $\begin{array}{l}\text { P: Isso } \\
\text { P: Gente vocês estão entendendo como vocês fazem confusão } \\
\text { com a grandeza massa e volume? } \\
\text { P: Então óh... quando eu pergunto qual a massa da água vocês } \\
\text { podem responder cinqüenta } \mathrm{mL} \text { ? }\end{array}$ & \\
\hline 43:35 & Al:Não & \\
\hline 43:37 & P: Cinqüenta $\mathrm{mL}$ é o quê? & \\
\hline 43:39 & Al: Volume & \\
\hline
\end{tabular}

Esse episódio revela a dificuldade que os alunos têm em diferenciar massa e volume. Utilizando um experimento demonstrativo investigativo simples, a professora permitiu que os alunos explicitassem suas idéias e com cautela, respeitando suas falas, foi mediando a construção desses conceitos. Nessa mesma aula, a professora pediu aos alunos que descrevessem com suas palavras os conceitos de massa e volume. Percebe-se, ao analisar essas questões, que alguns alunos ainda não haviam compreendido esses conceitos, o que é compreensível por se tratar de uma sala heterogênea e principalmente pelo fato de que a aprendizagem não ocorre com todos no mesmo momento, alguns alunos podem precisar de mais alguns subsídios para assimilar o novo conhecimento. 


\section{Segunda aula}

No início da aula, a professora pede para os alunos recordarem verbalmente o conceito de massa e de volume.

Novamente, utilizando o experimento demonstrativo investigativo da proveta descrito acima, a professora, medindo diferentes volumes de água, pretende que os alunos percebam que existe uma relação constante entre a massa e volume de uma mesma substância, ou seja, conceituar densidade. Nesse experimento algumas medidas foram ligeiramente imprecisas. Essa variação nas medidas dificultou um pouco o desenvolvimento da aula, pois o objetivo era o de obter valores o mais próximos um do outro para que os alunos percebessem que mesmo alterando o volume, a razão massa/volume seria a mesma. A tabela 4.1 mostra as razões massa/volume obtidas para a água:

Tabela 4.1- Medidas de densidade da água

\begin{tabular}{|c|c|c|}
\hline Massa (g) & Volume (mL) & Massa/Volume (g/mL) \\
\hline 36,35 & 40 & 0,91 \\
\hline 56,62 & 60 & 0,94 \\
\hline 76,74 & 80 & 0,96 \\
\hline 95,91 & 100 & 0,96 \\
\hline \multicolumn{3}{|c|}{ Massa da proveta: $117,06 \mathrm{~g}$} \\
\hline
\end{tabular}

A fala do aluno a seguir explicita a dificuldade no entendimento que as três primeiras medidas causaram:

\begin{tabular}{|c|c|c|}
\hline Tempo & Discurso & Análise \\
\hline 13:05 & $\begin{array}{l}\text { P: Olhando os dados que estão lá... dá para chegar alguma } \\
\text { conclusão? }\end{array}$ & P3 \\
\hline 13:09 & Al 5: Dá & \\
\hline 13:15 & $\begin{array}{l}\text { P: Qual? } \\
\text { P: Qual conclusão a gente chega ai? }\end{array}$ & \\
\hline 13:21 & $\begin{array}{l}\text { Al 5: Vai aumentando volume vai aumentando a relação massa e } \\
\text { volume }\end{array}$ & $\begin{array}{l}\text { N4 ((elabora uma } \\
\text { hipótese)) }\end{array}$ \\
\hline $13: 30$ & Al 1: Todos têm a mesma média & N3 \\
\hline 13:38 & $\begin{array}{l}\text { P:Todos...têm a mesma média } \\
\text { P: A gente tem duas idéias diferentes aqui...o Al } 5 \text { deu uma idéia e } \\
\text { o Al } 1 \text { tá dando outra idéia...fala alto sua idéia }\end{array}$ & \\
\hline 13:44 & Al 5: Vai aumentando volume vai aumentando massa sobre volume & $\mathrm{N} 4$ \\
\hline
\end{tabular}

Observa-se na fala de Al 5 que as medidas acabaram contribuindo para a concepção de que aumentando o volume de água a razão massa/volume aumentaria. Mesmo apresentando uma resposta não condizente com a questão proposta, o aluno mostra habilidades cognitivas pertencentes ao nível N4, uma vez que identifica uma 
variável, a relação massa/volume, e elabora uma hipótese para explicar seu raciocínio. A professora chama Al 5 para realizar a quarta medida e, finalmente, o valor coincide com o da terceira medida. O Al 1, ao contrário, já percebeu que essa variação é muito pequena e pode ter sido causada por erros de medida ou outras variáveis conforme evidenciam as falas a seguir:

\begin{tabular}{|l|l|l|}
\hline \multicolumn{1}{|c|}{ Tempo } & \multicolumn{1}{|c|}{ Discurso } & \multicolumn{1}{|c|}{ Análise } \\
\hline $16: 55$ & $\begin{array}{l}\text { P:Agora como vocês me explicam por que uma hora dá noventa e } \\
\text { um outra hora noventa e quatro outra hora noventa e seis? }\end{array}$ & P3 \\
\hline $16: 59$ & $\begin{array}{l}\text { Al 1:Por que você pode não ter colocado } \mathrm{mL} \text { certinho....pode dar } \\
\text { grama errado }\end{array}$ & $\mathrm{N} 4$ \\
\hline $17: 05$ & P: Errado? & \\
\hline $17: 06$ & Al 1:Variação & \\
\hline $17: 08$ & $\begin{array}{l}\text { P: Então quais são as fontes de variação experimental que a gente } \\
\text { tem? }\end{array}$ & P2 \\
\hline $17: 15$ & Al 1: A balança e o.. & \\
\hline $17: 17$ & P:A balança & \\
\hline $17: 19$ & Al 1: e o...a proveta... sei lá... & \\
\hline
\end{tabular}

Com a quarta medida, a professora consegue obter respostas condizentes com o problema proposto:

\begin{tabular}{|l|l|l|}
\hline \multicolumn{1}{|c|}{ Tempo } & \multicolumn{1}{|c|}{ Discurso } & \multicolumn{1}{|c|}{ Análise } \\
\hline $17: 55$ & $\begin{array}{l}\text { P: Por que vocês acham que eu pedi para vocês fazerem a divisão } \\
\text { da massa pelo volume? }\end{array}$ & P3 \\
\hline $18: 01$ & $\begin{array}{l}\text { Al: Para ver a relação } \\
\text { P: Mas e daí..tá eu sei deu zero vírgula nove e daí? } \\
\text { P: Que conclusão que a gente chegou que a relação massa } \\
\text { volume deu zero vírgula nove mais ou menos e que mais que ela } \\
\text { é... constante } \\
\text { P: Por que será eu pedi para vocês calcularem essa relação? }\end{array}$ & $\mathrm{N3}$ \\
\hline $18: 17$ & $\begin{array}{l}\text { Al 1: Para saber se quarenta mL era a mesma coisa que quarenta } \\
\text { gramas }\end{array}$ & $\mathrm{N} 4$ \\
\hline $18: 23$ & $\begin{array}{l}\text { P: Que isso me refresca....para que serve isso? } \\
\text { P: Saber que a relação é zero vírgula nove? }\end{array}$ & $\mathrm{P3}$ \\
\hline $18: 30$ & $\begin{array}{l}\text { Al 1: Para quando você tiver massa saber quanto é o volume e e } \\
\text { quando você tiver o volume saber quanto é a massa }\end{array}$ & $\mathrm{N} 4$ \\
\hline
\end{tabular}

Neste episódio, com a mediação da professora, o aluno começa a elaborar um raciocínio de que, com a constante, é possível conhecer as variáveis massa e volume.

Mas, a professora conseguiu contornar a dificuldade causada no primeiro experimento ao realizar o segundo experimento, utilizando álcool como o material investigado. Os volumes utilizados e as massas obtidas são apresentados na tabela 4.2 a seguir: 
Tabela 4.2- medidas de densidade do álcool

\begin{tabular}{|c|c|c|}
\hline Massa (g) & Volume (mL) & Massa/Volume $\mathbf{( g / m L )}$ \\
\hline 32,00 & 40 & 0,80 \\
\hline 48,37 & 60 & 0,81 \\
\hline 63,73 & 80 & 0,80 \\
\hline 78,65 & 100 & 0,79 \\
\hline \multicolumn{2}{|c|}{ Massa da proveta: $117,06 \mathrm{~g}$} \\
\hline
\end{tabular}

No segundo experimento, as variações foram muito menores, o que possibilitou aos alunos perceberem as semelhanças nas relações massa e volume:

\begin{tabular}{|l|l|l|}
\hline \multicolumn{1}{|c|}{ Tempo } & \multicolumn{1}{|c|}{ Discurso } & \multicolumn{1}{c|}{ Análise } \\
\hline $27: 30$ & $\begin{array}{l}\text { P: Por que será que eu tô fazendo a divisão massa pelo } \\
\text { volume...para que serve essa conta? }\end{array}$ & P3 \\
\hline $27: 49$ & Al: É uma média, não e? & N2 \\
\hline $27: 53$ & $\begin{array}{l}\text { P: Tá eu estou tirando uma média... eu tirei a média vamos dizer } \\
\text { Pssim.. que dá mais ou menos quanto... }\end{array}$ & P3 o que me refresca saber isso? \\
\hline $28: 14$ & $\begin{array}{l}\text { P: Vocês lembram da pergunta que fiz no começo dessa aula e no } \\
\text { começo da outra aula? } \\
\text { P: Dá para identificar um material pela massa...sim ou não? }\end{array}$ & \\
\hline $28: 27$ & Al: Não & \\
\hline $28: 30$ & $\begin{array}{l}\text { P: Não... se eu falar cinco gramas vocês vão saber que material } \\
\text { que é? }\end{array}$ & P3 \\
\hline $28: 32$ & Al: Não & \\
\hline $28: 35$ & $\begin{array}{l}\text { P: Dá para identificar um material pelo volume...sim ou não.. dez } \\
\text { mL? }\end{array}$ & \\
\hline $28: 44$ & Al: Não & N2 \\
\hline $28: 50$ & P: Dá para identificar material usando a divisão massa pelo volume & P3 \\
\hline $28: 54$ & Al: Sim & N2 \\
\hline
\end{tabular}

Esta seqüência mostra que as perguntas da professora podem ser categorizadas como nível P3, pois exigem do aluno avaliar as condições propostas e sugerir uma resposta. É importante salientar que diferentemente das aulas tradicionais, a professora até o momento não nomeou o conceito, ou seja, não mencionou o termo densidade.

A professora faz um terceiro experimento misturando metades iguais de água e álcool. Uma aluna começa e tentar buscar explicações para definir o conceito de densidade ainda desconhecido por eles, sugerindo como motivo de materiais diferentes apresentarem razões massa/volume diferentes, a "consistência dos materiais" como causa desta discrepância, evidenciando uma resposta de nível N4, que exige análise e possíveis soluções para o problema.

Ao misturar os materiais, a professora pede para os alunos sugerirem o valor esperado para a relação massa e volume: 


\begin{tabular}{|l|l|l|}
\hline \multicolumn{1}{|c|}{ Tempo } & \multicolumn{1}{|c|}{ Discurso } & \multicolumn{1}{|c|}{ Análise } \\
\hline $30: 55$ & $\begin{array}{l}\text { P: Alguém consegue chutar para mim qual a relação entre massa } \\
\text { volume? }\end{array}$ & P3 \\
\hline $31: 15$ & Al1: Oito vírgula cinco & $\mathrm{N} 4$ \\
\hline $31: 18$ & Al: Setenta e cinco & $\mathrm{N} 3$ \\
\hline $31: 20$ & $\begin{array}{l}\text { P: Por que setenta e cinco? } \\
\text { P: Por que oitenta e cinco? }\end{array}$ & P3 \\
\hline $31: 26$ & Al 1: Tá entre 8 e 9 & $\mathrm{N} 4$ \\
\hline $31: 30$ & P: Tá entre 8 e 9 & \\
\hline
\end{tabular}

Novamente, observa-se um momento de elaboração de hipótese por parte do Al 1, sempre com a mediação da professora.

Somente no final da aula a professora evoca as idéias dos alunos em relação aos conhecimentos construídos nas duas aulas e conceitua densidade fazendo relações e generalizando:

\begin{tabular}{|c|c|c|}
\hline Tempo & Discurso & Análise \\
\hline $37: 49$ & $\begin{array}{l}\text { P: Minha questão agora volta...eu posso usar posso usar a relação } \\
\text { massa volume para identificar um material... sim ou não? }\end{array}$ & P3 \\
\hline $37: 57$ & $\begin{array}{l}\text { P: Vocês entenderam ou não isso gente? } \\
\text { P: Qual a relação massa volume da água? }\end{array}$ & P2 \\
\hline $38: 05$ & Al: Zero vírgula noventa e um & \\
\hline $38: 07$ & $\begin{array}{l}\text { P: Zero vírgula nove... a gente pode até tirar a média mas vamos } \\
\text { ficar no zero vírgula nove } \\
\text { P: Se eu fizer outra amostra de cinco } \mathrm{mL} \text { de água vocês são } \\
\text { capazes de me dizer qual será a relação massa volume sem eu } \\
\text { pesar lá? }\end{array}$ & P2 \\
\hline $38: 22$ & Al 1: Zero vírgula nove? & N3 \\
\hline $38: 24$ & $\begin{array}{l}\text { P: Zero vírgula nove } \\
\text { P: E se eu fizer cinco } \mathrm{mL} \text { de álcool quanto vai será relação massa } \\
\text { volume? }\end{array}$ & P2 \\
\hline $38: 30$ & Al 1 : zero vírgula oito & N3 \\
\hline $38: 33$ & $\begin{array}{l}\text { P: Zero vírgula oito } \\
\text { P: Então oh essa relação massa volume ela permite que eu } \\
\text { identifique um material } \\
\text { P: E ela recebe um nome...alguém sabe o nome dessa relação? } \\
\text { P: Densidade...já ouviram falar em densidade? } \\
\text { P: A relação massa volume...é a densidade }\end{array}$ & \\
\hline
\end{tabular}

As demonstrações realizadas pela professora se caracterizam como atividades investigativas, pois envolvem a participação ativa do aluno na resolução de um problema proposto, permitindo que esses questionem, explicitem suas idéias, discutam com seus pares e elaborem hipóteses (CARVALHO et al., 1999).

Para Gil Perez et al. (2005), a hipótese tem um papel articulador e dialógico entre as teorias, as observações e as experimentações. Conforme mostram as falas, as demonstrações realizadas pela professora permitiram momentos que privilegiam 
habilidades cognitivas de nível N3 e N4, contribuindo significativamente para a elaboração de hipóteses.

Partindo de experimentos demonstrativos, a professora discutiu com os alunos os conceitos de massa, volume e densidade, mediando com questões elicitativas, e não com questões avaliativas, e contribuindo para a construção do conhecimento científico escolar.

\section{Terceira aula}

Esta aula teve duração de aproximadamente vinte minutos. O restante da aula foi utilizado para a realização dos experimentos pelos alunos.

O objetivo da aula era generalizar o conceito de densidade desenvolvido nas duas aulas anteriores, abordando o conhecimento em outros contextos. A professora questionou os alunos perguntando se ao adicionar sal na água, a densidade, ou a relação massa/volume se modificaria.

Com o auxílio do experimento do ovo em um béquer com água e adições sucessivas de sal, a professora procurou mostrar que a densidade de um material se altera com a adição de outro material, evidenciado pela flutuação do ovo em uma solução saturada.

Uma seqüência de falas revela que a professora procura que os alunos, partindo dos conceitos aprendidos, formulem hipóteses e avaliem as condições propostas por ela no problema. Os alunos elaboraram respostas que exigem a seleção das informações, análise de variáveis e proposição de hipóteses, habilidades que caracterizam os níveis N3 e N4 de cognição:

\begin{tabular}{|l|l|l|}
\hline \multicolumn{1}{|c|}{ Tempo Discurso } & \multicolumn{1}{|c|}{ Análise } \\
\hline $05: 26$ & P: Por que será que ele afundou na água? & P2 \\
\hline $05: 31$ & Al: Porque é mais denso & $\mathrm{N} 3$ \\
\hline $05: 33$ & $\begin{array}{l}\text { P: Porque ele é mais denso que a água } \\
\text { P: Olha aqui..que vai acontecer se eu colocar sal? }\end{array}$ & P3 \\
\hline $05: 45$ & Al 1: Vai aumentar o peso & $\mathrm{N} 2$ \\
\hline $05: 49$ & P:Vai aumentar o peso do quê? & P3 \\
\hline $05: 51$ & Al: Da água & $\mathrm{N} 3$ \\
\hline $05: 53$ & Al: Vai aumentar a densidade da água ((ou melhor, da solução)) & $\mathrm{N} 4$ \\
\hline $05: 55$ & $\begin{array}{l}\text { P: Vai aumentar a densidade da água } \\
\text { P: Que vai acontecer com ovo? }\end{array}$ & P3 \\
\hline $05: 56$ & Al 1: Vai boiar & $\mathrm{N} 3$ \\
\hline $05: 57$ & P: Por quê ? & \\
\hline $06: 00$ & Al 1: Porque vai ficar menos denso & $\mathrm{N} 4$ \\
\hline
\end{tabular}


Neste episódio, a professora precisou atentar-se para os alunos não deduzirem que a densidade do ovo diminuía ao invés da densidade da solução, conforme mostra o episódio a seguir:

\begin{tabular}{|l|l|l|}
\hline \multicolumn{1}{|c|}{ Tempo } & \multicolumn{1}{|c|}{ Discurso } & \multicolumn{1}{c|}{ Análise } \\
\hline $06: 49$ & P: O que tá acontecendo com o ovo? & P2 \\
\hline $07: 01$ & Alunos: Tá boiando & N2 \\
\hline $07: 05$ & $\begin{array}{l}\text { P: Da para ver Al7? } \\
\text { P:Que aconteceu com o ovo agora? }\end{array}$ & \\
\hline $07: 25$ & P:Tá... boiando... antes tava boiando? & P2 \\
\hline $07: 27$ & Al: Não & N2 \\
\hline $07: 32$ & $\begin{array}{l}\text { P: Então oh... por que.. } \\
\text { P: O Al1 tava explicando... por que o ovo passou a boiar na água? }\end{array}$ & P2 \\
\hline $07: 40$ & Al 4: Porque a densidade da água aumentou & N3 \\
\hline $07: 45$ & Al: Aumentou a da água? & N2 \\
\hline $07: 48$ & Al: A do ovo é menor que da água & N3 \\
\hline $07: 49$ & Al 4: A densidade da água aumentou e do ovo continuou igual & N4 \\
\hline $07: 55$ & $\begin{array}{l}\text { P: Isso... a densidade da água aumentou e da ovo continuou igual } \\
\text { P:Portanto se a da água aumentou e do ovo continuou igual o que } \\
\text { acontece com ovo? } \\
\text { P: Ele passa a ...boiar }\end{array}$ & \\
\hline
\end{tabular}

Na figura 1 são apresentadas as freqüências dos níveis para as questões propostas pela professora e na figura 2 as freqüências dos níveis das respostas dos alunos com relação às habilidades cognitivas, nas três primeiras aulas. Observa-se um elevado número de respostas que revelam habilidades cognitivas classificadas nos níveis N3 e N4, condizentes com as perguntas do professor, as quais exigem esse tipo de respostas. Os objetivos são atingidos uma vez que as respostas dadas exibem processo de controle, análise de variáveis e suas relações causais.

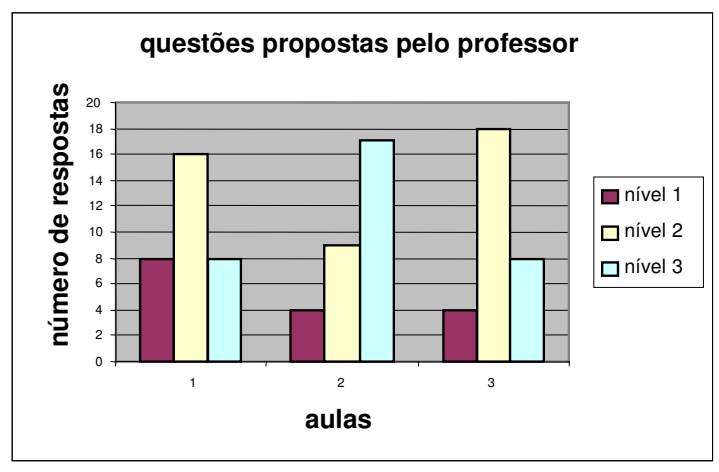

Figura 1. Nível de cognição das questões propostas pelo professor

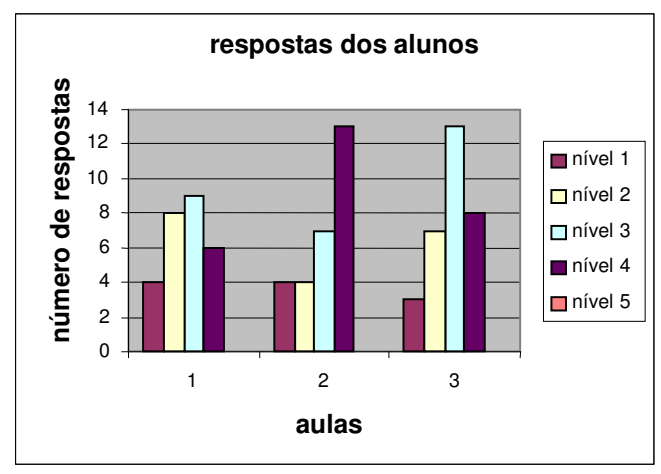

Figura 2. Nível cognitivo das respostas dos alunos 
A maior parte das questões propostas pela professora na primeira aula é classificada no nível P2 de cognição, diferentemente da segunda aula, a qual apresenta um elevado número de questões classificadas no nível P3. Essa diferença pode estar relacionada ao propósito da aula.

Na primeira aula, a professora pretende conceituar massa e volume e se restringe, muitas vezes, a propor questões de comparação e aplicação de leis. As respostas dos alunos nesta aula são condizentes com as perguntas, pois são classificadas em maior número nos níveis N2 e N3, os quais exigem habilidades cognitivas de baixa ordem, como por exemplo, aplicar fórmulas ou explicar o problema com conceitos relembrados. Porém, na segunda aula, quando a professora organiza no quadro os dados encontrados nas medidas de massa e volume de água e álcool, elabora questões que exigem dos alunos fazer inferências, avaliar as condições de contorno e propor hipóteses, o que é evidenciado no alto número de respostas classificados no nível N4 de cognição, onde o aluno seleciona as informações relevantes para a solução do problema, elabora hipóteses e sugere possíveis conclusões.

$\mathrm{Na}$ terceira aula pode-se atribuir o elevado número de questões de nível P2 propostas pela professora a dois motivos. O primeiro, refere-se à duração da aula, de aproximadamente vinte minutos, pois o restante foi utilizado para a realização do experimento. Outro motivo pode ser atribuído novamente ao objetivo da aula, na qual a professora conceituou densidade e apresentou à sala o densímetro como instrumento de medida, não permitindo muitos momentos de diálogo com os alunos. Stamovlasis et al. (2005), argumentam que o grau em que uma questão é categorizada como conceitual (HOCS) depende, de certa maneira, do tipo de ensino a que o aluno está exposto nas aulas, corroborando os dados obtidos na presente pesquisa.

Por fim, as análises das aulas de demonstração investigativa evidenciam que os experimentos contribuíram para a reflexão dos alunos sobre os problemas propostos, permitindo-os participar do levantamento de hipóteses, análise dos dados e suas possíveis soluções. O professor teve papel importante no desenvolvimento da aula, procurando valorizar as falas dos alunos, que, pareciam participar ativamente da construção do conhecimento químico. 


\section{A atividade experimental realizada pelos alunos}

Os alunos deveriam realizar medidas de densidade de sólidos e líquidos no laboratório e identificá-los comparando os valores obtidos com os apresentados em uma tabela "padrão" disponibilizada pela professora, com valores de densidade obtidos da literatura. Os valores se aproximariam dos apresentados na tabela, e eles deveriam utilizar esse raciocínio para a identificação. A professora esperava que os alunos identificassem as amostras mas, ao mesmo tempo, conforme mostram as questões escritas da próxima seção, os alunos deveriam perceber que algumas amostras poderiam apresentar valores de densidades próximos, o que dificultaria a sua identificação. A tabela 4.3, a seguir, elaborada pela pesquisadora para facilitar a visualização, mostra os sólidos e os líquidos utilizados no experimento e suas respectivas densidades. Cada grupo identificou três amostras sólidas e duas líquidas.

Tabela 4.3- Amostras sólidas e líquidas utilizadas no experimento

\begin{tabular}{|c|c|c|c|}
\hline Amostra líquida & Densidade (g/mL) & Amostra sólida & Densidade (g/mL) \\
\hline Água & 1,0 & $\mathrm{Cu}$ & 8,92 \\
\hline Álcool etílico & 0,8 & $\mathrm{Al}$ & 2,70 \\
\hline Óleo & 0,9 & $\mathrm{~Pb}$ & 11,3 \\
\hline Mel & 1,4 & $\mathrm{Zn}$ & 7,14 \\
\hline Água com sal (200 g de sal para 1L de água) & 1,1 & \multicolumn{2}{|l}{}
\end{tabular}

Apresentam-se algumas falas de um dos grupos de alunos durante a atividade experimental e uma discussão das habilidades cognitivas manifestadas a partir dessas falas.

No início do experimento os alunos, ainda um pouco eufóricos e tensos, não lêem o protocolo (Anexo C) e acabam errando o procedimento. Ao invés de realizarem o experimento para calcular a densidade do sólido, os alunos calculam a densidade da água na proveta utilizando o densímetro:

Al 3: Cara não tem que medir a densidade disso aqui...é densidade do metal que a gente tá medindo óh sólido

Al 1: Medir a densidade do material sólido

Al 3: A gente fez da água então

Al 1: Não da água

Al 1: Sólido...sólido ((em tom enfático))

Al1: Aqui tem oh 
Após medir o volume final da água com a adição do sólido, os alunos fazem os cálculos de densidade, mas utilizam o valor inicial da água e não a sua diferença:

Al: Eu vou falando..deixa eu ver..

Al 1: Faz ai quarenta e um vírgula quinze dividido

Al 2: É isso massa por volume ou volume pela massa?

Al 1:Dividido por cinqüenta e cinco

Al 2: Zero vírgula setenta e quatro o primeiro

Al 1:O segundo é...seis virgula trinta e dois

Al 1: Dividido por cinqüenta e cinco

Al 2: Zero vírgula onze ou quatorze ((densidade errada))

Al 2:Onze

Al 1: Terceiro vinte e quatro vírgula vinte e quatro dividido por cinqüenta e cinco

Al 2: Zero virgula quarenta e quatro

Al 3: É isso? ((perguntam ao laboratorista que trabalha na escola e ajuda a professora a preparar os experimentos))

Lab: Risos..você vai medir o volume do sólido mas não é o volume total

Al 2: Ah é

Al 2:Certo?

Al 3: Rafael traz a calculadora que tá errado

Os alunos cometem outro erro ao calcular a densidade, calculam volume/ massa e não massa/volume:

Al 1: Oh Lab... um pouquinho

Al 1: O sólido tem seis ponto trinta e dois...só que o volume dele deu onze..vai dar um número bem baixo a densidade... que é massa dividido por volume... deu zero virgula cinqüenta e sete

Al 1: Que é esse daqui oh

Lab: Qual foi o volume de vocês?

Al 1: Foi esse daqui óh

Lab: Qual é massa dele?

Lab: Não ... tá errado de novo

Al: Que raiva

Al 2: Tá errado de novo?

Al 1: É ao contrário

Al 3 :Vai ter que calcular tudo de novo? 
O erro, que faz parte do processo de aprendizagem, não foi transformado em um obstáculo que intimidasse $o$ aluno a participar da aula.

Durante a execução do experimento, os alunos procuram a ajuda do laboratorista, de alguém com maior conhecimento para orientá-los, corroborando a proposta de Gil-Perez e colaboradores, a qual defende a participação de um "expert" para ajudar os novatos em uma atividade experimental investigativa. Este grupo de alunos recorreu ao laboratorista e não à professora porque no momento ela estava atendendo outros grupos no laboratório.

É importante relatar que o laboratorista informa aos alunos que os cálculos estão incorretos, mas não exprime qualquer caminho para a sua resolução, não os direcionando em suas decisões.

Durante a atividade experimental os alunos interagem constantemente, expondo suas idéias e discutindo com seus pares. Para a resolução dos problemas propostos pela professora, os alunos precisaram selecionar as informações relevantes, analisar as variáveis (volume, massa e densidade dos sólidos e líquidos) e propor uma solução para o problema, identificando com o auxílio da tabela de densidade quais eram os materiais analisados.

Para Pintrich e colaboradores (1993), entre os fatores capazes de proporcionar o desenvolvimento de habilidades cognitivas estão o desenvolvimento de habilidades de processamento, a elaboração e organização, a resolução de problemas e a utilização de habilidades cognitivas de controle e regulação.

A sociedade exige cada vez mais um cidadão capaz de tomar decisões e propor soluções para os problemas enfrentados. Desta forma, a proposição de atividades escolares que contribuam para a formação deste indivíduo se torna uma necessidade.

\section{O Pós - Laboratório}

Após a realização do experimento, a professora discute com toda a classe os resultados obtidos nos grupos:

\begin{tabular}{|l|l|l|}
\hline \multicolumn{1}{|c|}{ Tempo } & \multicolumn{1}{|c|}{ Discurso } & \multicolumn{1}{c|}{ Análise } \\
\hline $35: 33$ & $\begin{array}{l}\text { P:As densidades que vocês obtiveram foram iguais a essas em } \\
\text { todos os casos? }\end{array}$ & P2 \\
\hline $35: 36$ & Al:Não & \\
\hline $35: 38$ & P:Como é que vocês fizeram aqui para identificar as amostras? & P2 \\
\hline $35: 40$ & Al 1: O mais aproximado & $\mathrm{N} 3$ \\
\hline $35: 45$ & $\begin{array}{l}\text { P:Isso...vocês aproximaram a densidade que vocês encontraram } \\
\text { dessa densidade aqui padrão } \\
\text { P:Como é que vocês explicam o fato de vocês não terem chegado }\end{array}$ & P3 \\
\hline
\end{tabular}




\begin{tabular}{|l|l|l|}
\hline & exatamente a esses valores aqui & \\
\hline $35: 56$ & Al: Erro & $\mathrm{N} 2$ \\
\hline 36:02 & P:Fala Al & \\
\hline 36:08 & Al1: Pode ser variação da balança na hora de pesar o volume & N4 \\
\hline
\end{tabular}

Em outro trecho:

\begin{tabular}{|c|c|c|}
\hline Tempo & Discurso & Análise \\
\hline 39:56 & $\begin{array}{l}\text { P: Por que a densidade obtida pode não ter sido exatamente a } \\
\text { densidade padrão do material que eu peguei lá no material... Então } \\
\text { lá... densidade do cobre tanto... }\end{array}$ & P3 \\
\hline 40:07 & $\begin{array}{l}\text { Al 1: Porque o material pode não ser cem por cento cobre cem por } \\
\text { cento zinco (j) }\end{array}$ & \\
\hline 40:13 & $\begin{array}{l}\text { P:Perfeito olha só o que o Al1 colocou vocês ouviram? } \\
\text { P: Al1 você estava me falando que o material pode não ser cem } \\
\text { por cento }\end{array}$ & \\
\hline 40:25 & $\begin{array}{l}\text { Al1: Cobre, ou zinco ou o material que você esta querendo } \\
\text { determinar a densidade (I) }\end{array}$ & \\
\hline 40:30 & $\begin{array}{l}\text { P:Se tiver uma outra coisa misturada no material o que pode } \\
\text { acontecer coma densidade }\end{array}$ & P3 \\
\hline $40: 33$ & Al1: Pode ser maior ou menor (m) & N4 $(\mathrm{j}, \mathrm{l}, \mathrm{m})$ \\
\hline $40: 36$ & P: Isso então olha aqui & \\
\hline
\end{tabular}

Neste episódio, a professora conduz os alunos à procura de uma resposta condizente para o problema, ou seja, o por quê das densidades não terem dado valores exatos, e sim aproximados. O aluno 2 sugere uma variação na medida e a professora explora as idéias dos alunos até o momento em que o aluno 1 elabora uma hipótese, argumentando que o material analisado poderia não ser puro, o que alteraria a sua densidade.

No total, a professora propõe 18 questões para discussão com os alunos. Destas questões, 11 foram classificadas no nível P3 de cognição. Com relação às respostas dadas pelos alunos prevaleceram as de nível de cognição alto (HOCS). Assim, das dezoito respostas elaboradas pelos alunos, oito foram categorizadas no nível N4 e quatro de nível N3.

Ao analisar a seqüência de aulas investigativas aplicadas pela professora A, verifica-se que os objetivos propostos por ela podem ter sido alcançados. Os alunos parecem ter compreendido os conceitos de massa e volume e, também, a razão massa/volume como uma propriedade de cada material. Durante o experimento investigativo realizado no laboratório os alunos conseguiram identificar os materiais sólidos e líquidos ao comparar os valores de densidades obtidos com os da "tabela padrão", evidenciando a manifestação de habilidades cognitivas de alta ordem. 


\subsubsection{Primeira Série II}

A seqüência de aulas da professora da escola A para a primeira série II do ensino médio foi muito parecida com a seqüência de aulas da primeira série I, uma vez que se trata do mesmo conteúdo abordado e a mesma conduta desenvolvida pela professora. Porém, os alunos são outros, a sala apresenta características próprias, podendo diferenciar em alguns aspectos da aula e conseqüentemente na análise.

Desta forma, será apresentada aqui a análise das aulas da mesma forma como apresentada para a primeira série I, a fim de verificar possíveis diferenças ou singularidades referentes à postura da professora e dos alunos. Mas, não se atentará à descrição minuciosa do que foi exposto na aula, pois as idéias norteadoras são as mesmas. A diferença na seqüência de aulas se apresenta no número total de aulas, pois a professora utilizou cinco aulas para a série II, enquanto que para a série I foram utilizadas quatro aulas para o desenvolvimento do conceito.

\section{Primeira aula}

A professora inicia a aula relembrando o experimento de Lavoisier e questiona como ele poderia saber que o material obtido era realmente água, questionando os alunos com a seguinte pergunta: "Como podemos identificar um material?".

Os alunos começam a elaborar suas hipóteses:

\begin{tabular}{|l|l|l|}
\hline \multicolumn{1}{|c|}{ Tempo } & \multicolumn{1}{|c|}{ Discurso } & \multicolumn{1}{|c|}{ Análise } \\
\hline $04: 50$ & $\begin{array}{l}\text { P: Deixa eu perguntar outra coisa... vocês acham que... a gente } \\
\text { estudou até agora a conservação das massas...não estudou? } \\
\text { P: E proporção das massas...será que massa dá pra gente } \\
\text { identificar um material? } \\
\text { P: Que que vocês acham...a massa é uma propriedade que } \\
\text { permite que eu identifique o material? }\end{array}$ & P3 \\
\hline $05: 05$ & $\begin{array}{l}\text { Al 1: Alguma coisa para comparar...tabela (a) } \\
\text { P: Se eu tiver alguma coisa pra comparar... o que que eu vou } \\
\text { fazer? }\end{array}$ & \\
\hline $05: 17$ & Al 1: Se você tiver um ponto de referência... aí... (b) & \\
\hline $05: 19$ & P: Um ponto de referência? & \\
\hline $05: 22$ & Al 1: Pega um copo de água e então...(inaudível) (c) & \\
\hline $05: 30$ & $\begin{array}{l}\text { P: Ôh o Al1 tá dando uma idéia aqui...presta atenção... olha o que } \\
\text { o Al1 tá falando... } \\
\text { P:Se eu tiver uma referência... assim... um copo de água é igual a }\end{array}$ & \\
\hline
\end{tabular}




\begin{tabular}{|l|l|l|}
\hline & $\begin{array}{l}\text { tantos gramas... então eu tenho essa referência... se eu tiver... } \\
\text { como é que continua o raciocínio? } \\
\text { P:Como é que eu faria depois? }\end{array}$ & \\
\hline $05: 45$ & Al 1:Ai você faz um copo desse ...desse liquido (d) & \\
\hline $05: 49$ & $\begin{array}{l}\text { P: Aí você faz o copo desse líquido, o que e que tem que dar } \\
\text { igual? }\end{array}$ & N4 (a,b,c,d,e) \\
\hline $05: 53$ & Al 1:A massa (e) & \\
\hline $05: 55$ & $\begin{array}{l}\text { P:A massa tem que dar igual...e ai você vai saber...que esse } \\
\text { líquido... é a água...é uma hipótese.... gente vai pensar sobre ela. } \\
\text { P:Justamente...gente... é isso que a gente vai discutir um pouco } \\
\text { hoje. }\end{array}$ & \\
\hline
\end{tabular}

Neste diálogo, é de suma importância a postura da professora em conduzir o raciocínio do aluno para a elaboração de sua hipótese, pois o raciocínio do aluno não se apresenta em uma única frase, mas sim, em uma seqüência de idéias guiadas pela professora. Com o auxílio da professora, fica claro que o aluno sugere comparar a massa de um copo de água com um valor de referência, propondo uma hipótese para a solução do problema, sendo sua resposta classificada no nível N4.

Então, com o objetivo de construir o conceito de massa e volume antes de conceituar densidade, a professora pesa diferentes volumes de mesma massa de algodão e de chumbo:

\begin{tabular}{|l|l|l|}
\hline \multicolumn{1}{|c|}{ Tempo } & \multicolumn{1}{|c|}{ Discurso } & \multicolumn{1}{|c|}{ Análise } \\
\hline $32: 02$ & $\begin{array}{l}\text { P:Amostra de chumbo e algodão...qual a massa de cada amostra? } \\
\text { P:Vocês anotaram né? } \\
\text { P:Há semelhanças entre as amostras de chumbo e algodão? }\end{array}$ & P2 \\
\hline $32: 12$ & Al: Sim & \\
\hline $32: 14$ & P: Quais são as semelhanças? & P2 \\
\hline $32: 15$ & Al: O peso que elas pesam & $\mathrm{N} 2$ \\
\hline $32: 15$ & Al3: O peso & $\mathrm{N} 2$ \\
\hline $32: 19$ & $\begin{array}{l}\text { P: A massa...o peso..muito bem....são semelhantes né...muito bem } \\
\text { P: O que que é diferente? }\end{array}$ & P2 \\
\hline $32: 25$ & Al: É o volume & $\mathrm{N} 2$ \\
\hline $32: 27$ & P: Isso...o volume....por que...gente... quem tem é maior volume? & P2 \\
\hline $32: 32$ & Al: O algodão. & $\mathrm{N} 2$ \\
\hline $32: 34$ & P: Por que...por que ele ocupa um espaço...? & P2 \\
\hline $32: 37$ & A: Maior & $\mathrm{N} 2$ \\
\hline $32: 37$ & P: Maior. & \\
\hline $32: 40$ & P: O chumbo ocupa um espaço...? & P2 \\
\hline $32: 42$ & Al: Menor. & $\mathrm{N} 2$ \\
\hline $32: 44$ & P:Menor...muito bem...o chumbo é mais compacto...muito bem. & \\
\hline
\end{tabular}

A professora passa os frasquinhos contendo volumes idênticos de mercúrio, água e alumínio para que os alunos verifiquem as diferenças em suas massas.

Em seguida retoma a hipótese inicial do aluno: 


\begin{tabular}{|c|c|c|}
\hline Tempo & Discurso & Análise \\
\hline $35: 20$ & $\begin{array}{l}\text { P: Mas fala sua hipótese de novo...fala sua hipótese para } \\
\text { identificar o material. }\end{array}$ & \\
\hline $35: 23$ & $\begin{array}{l}\text { Al1: E se eu... se eu soubesse o... valor que tinha no copo de água } \\
\text { de... da massa poderia saber se ele fosse... o líquido fosse } \\
\text { igual...talvez fosse... sei lá... }\end{array}$ & N4 \\
\hline $35: 36$ & $\begin{array}{l}\text { P: Desse pra identificar } \\
\text { P: Então copo de água...oh vamos pegar a idéia do Al } 1 \text {...eu pego } \\
\text { um copo coloco água lá...oh vou colocar na lousa...eu pego um } \\
\text { copo, e coloco água. }\end{array}$ & \\
\hline 36:05 & $\begin{array}{l}\text { P: E aí Al1...o que eu faço...coloquei água no meu copo...o que eu } \\
\text { faço depois? }\end{array}$ & \\
\hline $36: 07$ & Al1: Pesa & \\
\hline 36:08 & $\begin{array}{l}\text { P: Pesa...aí vai dar...massa igual...quando eu...tanto...quando eu } \\
\text { coloco água no copo gente... presta atenção }\end{array}$ & \\
\hline $36: 18$ & A1: Não tem que tirar alguma coisa do copo...vazio? & N3 \\
\hline 36:21 & $\begin{array}{l}\text { P: Vamos lá...então primeiro eu peso massa do copo vazio... eu } \\
\text { tenho tanto...depois eu tiro...massa total menos a massa do copo } \\
\text { certo Al1? }\end{array}$ & \\
\hline $36: 44$ & Al1: Oi? & \\
\hline $36: 45$ & Al: Não professora é o seguinte... ((não continua)) & \\
\hline $36: 47$ & P: É igual a massa de água...é isso que você pensou? & \\
\hline 36:50 & $\begin{array}{l}\text { Al1: Na verdade eu não sei o que eu pensei... mas eu pensei que } \\
\text { assim que... tem que tirar a massa do copo ... ficar mais... como é } \\
\text { que fala? ((alunos comentam em cima do resto da frase - } \\
\text { ininteligível)) }\end{array}$ & N3 \\
\hline 37:05 & $\begin{array}{l}\text { P: Então eu posso por exemplo... perfeito...eu posso pesar o copo } \\
\text { vazio... tem o número lá...depois... }\end{array}$ & \\
\hline $37: 06$ & Al: Não tem que descontar? & N3 \\
\hline $37: 15$ & $\begin{array}{l}\text { P: Isso... desconta né...a massa do copo menos... a massa de... a } \\
\text { massa do copo...a massa total mais fácil né... menos a massa do } \\
\text { copo é igual a massa de água...certo? } \\
\text { P: Desconta a massa do copo...não é isso que tá lá? } \\
\text { P: Bom tá bom }\end{array}$ & \\
\hline $37: 39$ & $\begin{array}{l}\text { P: Então assim... quando eu coloco... um minuto! (alunos começam } \\
\text { a guardar o material) } \\
\text { P: Quando eu coloco... a água no copo, o que que eu meço...o que } \\
\text { que eu tô medindo quando eu coloco água no copo lá desse jeito? }\end{array}$ & P2 \\
\hline $37: 53$ & $\begin{array}{l}\text { P:Por que que é importante colocar água no copo? } \\
\text { P:Além de massa dá pra medir alguma outra coisa? }\end{array}$ & P2 \\
\hline $37: 57$ & Al: Volume & N3 \\
\hline $37: 59$ & $\begin{array}{l}\text { P: O volume....porque o copo vai controlar o volume que eu tenho } \\
\text { também.....controlar a massa mas controlar o volume também }\end{array}$ & \\
\hline
\end{tabular}

Diferentemente da primeira série I, a professora não inicia o experimento da proveta. A primeira aula se restringiu ao desenvolvimento dos conceitos de massa e volume. 


\section{Segunda aula}

$\mathrm{Na}$ segunda aula, a professora inicia a aula retomando a hipótese do aluno e inicia o mesmo experimento da proveta realizado com a outra sala:

\begin{tabular}{|c|c|c|}
\hline Tempo & Discurso & Análise \\
\hline 05:01 & $\begin{array}{l}\text { P:O Al1 tinha uma hipótese que era assim...se eu pegar um copo } \\
\text { com água de volume conhecido e pegar um copo com um liquido } \\
\text { qualquer com um volume igual e medir a massa dos dois eu posso } \\
\text { descobrir que isso e água ou não? } \\
\text { P:Lembra da sua hipótese Al1? } \\
\text { P:Ele tinha pensado assim óh...Como é que eu posso identificar } \\
\text { um material pela massa ou pelo volume? } \\
\text { P:Ele pensou o seguinte pegar um copo com água mediu o volume } \\
\text { da água medir a massa da água e eu comparar com um outro } \\
\text { material que eu não sei qual é que eu tenho o mesmo volume eu } \\
\text { vejo a massa eu posso chegar à conclusão se isso é água ou não } \\
\text { P:Nós vamos pensar um pouco sobre a hipótese do Al1 } \\
\text { P:Mas até no final da aula ela falou assim mas será professora que } \\
\text { isso funciona ou não? }\end{array}$ & \\
\hline 07:48 & $\begin{array}{l}\mathrm{P}: \text { Então oh o volume de água é trinta } \mathrm{mL} \\
\mathrm{P}: \text { Essa massa cento e quarenta e três virgula noventa e nove é a } \\
\text { massa do que? }\end{array}$ & P3 \\
\hline 07:02 & Al2: Da água com o copinho & $\begin{array}{l}\text { N4 avalia as } \\
\text { condições }\end{array}$ \\
\hline 07:06 & P:Da água com o copinho que chama proveta & \\
\hline 07:07 & Al2: É proveta & \\
\hline $07: 40$ & $\begin{array}{l}\text { P:Então oh pergunta... como e que eu faço para saber a massa da } \\
\text { água? }\end{array}$ & P3 \\
\hline 07:45 & Al: Desconta o peso da proveta & $\mathrm{N} 4$ \\
\hline 07:50 & P:Desconta o peso da proveta & \\
\hline
\end{tabular}

A professora monta uma tabela na lousa e explica aos alunos o que será feito. Um aluno então pergunta se esta tabela será feita utilizando-se o mesmo material e a professora aproveita a sua pergunta para que eles pensem sobre os resultados que poderão ser obtidos com a tabela:

\begin{tabular}{|l|l|l|}
\hline Tempo & \multicolumn{1}{|c|}{ Discurso } & \multicolumn{1}{|c|}{ Análise } \\
\hline $11: 10$ & $\begin{array}{l}\text { P:Oh eu vou fazer o seguinte...nós vamos pesar várias amostras } \\
\text { de água e a gente vai medir } \\
\text { P:A gente vai pegar varias amostras de água..e ai a gente vai } \\
\text { colocar na tabela a massa o volume e a gente vai calcular a } \\
\text { relação massa volume } \\
\text { P:Só que eu não vou por na lousa vocês que vão anotar }\end{array}$ & \\
\hline $12: 45$ & Al3: Do mesmo material? & \\
\hline $12: 49$ & P:Vou pegar do mesmo material..por que? & P3 \\
\hline $13: 01$ & $\begin{array}{l}\text { P:Al3 pensa um pouco } \\
\text { P:Será que ...você tem essa hipótese que a relação massa e } \\
\text { volume ajuda a gente identificar um material } \\
\text { P:Se a relação massa e volume permitir a gente identificar um } \\
\text { material o que deve acontecer com essa tabela? } \\
\text { O que vocês acham que vai acontecer? }\end{array}$ & P3 \\
\hline
\end{tabular}




\begin{tabular}{|c|c|c|}
\hline 13:18 & Al4: Vai ser proporcional (a) & \\
\hline 13:24 & $\begin{array}{l}\text { P:Como que vai ser proporcional Al4 ...que grandeza vai ser } \\
\text { proporcional? }\end{array}$ & \\
\hline $13: 28$ & Al4: Tipo a grandeza massa volume (inaudível) (b) & \\
\hline 13:42 & $\begin{array}{l}\text { P:O que o Al4 tá falando } \\
\text { P:Eu perguntei o seguinte ...ouçam a pergunta... o que vocês } \\
\text { esperam obter daquele resultado ali? } \\
\text { P:O que vocês esperam obter daqueles resultados..vocês esperam } \\
\text { alguma coisa? } \\
\text { P:O que vocês esperam dessa tabela....vocês têm alguma } \\
\text { expectativa? }\end{array}$ & P3 \\
\hline 13:58 & Al4: Que a variação se mantenha (c) & \\
\hline 13:59 & $\begin{array}{l}\mathrm{P}: \text { Que a variação se mantenha? } \\
\mathrm{P}: \text { Bom ...que...essa massa barra volume é a divisão da massa pelo } \\
\text { volume...O Al4 tem uma expectativa alguém mais tem alguma } \\
\text { expectativa? }\end{array}$ & \\
\hline $14: 19$ & Al1:Que seja igual (d) & $\mathrm{N} 4(\mathrm{a}, \mathrm{b}, \mathrm{c}, \mathrm{d})$ \\
\hline $14: 23$ & P:Que essa divisão seja igual para todos..por que Al1? & \\
\hline $14: 28$ & $\begin{array}{l}\text { Al1: inaudível ((barulhos na escolha em reforma...parece algo } \\
\text { sobre se tratar de água)) }\end{array}$ & \\
\hline 14:33 & $\begin{array}{l}\text { P:Então nós vamos retomar vamos ver se acontece isso coma } \\
\text { água...acompanha aqui }\end{array}$ & \\
\hline
\end{tabular}

A professora realiza as medidas para a água e os resultados obtidos são organizados em uma tabela na lousa, conforme representado na tabela 4.4 abaixo:

Tabela 4.4- Medidas de densidade da água

\begin{tabular}{|c|c|c|}
\hline Massa (g) & Volume $(\mathbf{m L})$ & Massa/volume $\mathbf{( g / m L})$ \\
\hline 27,15 & 30 & 0,905 \\
\hline 36,91 & 40 & 0922 \\
\hline 56,58 & 60 & 0,943 \\
\hline 97,32 & 100 & 0,973 \\
\hline
\end{tabular}

É interessante verificar que novamente os valores da relação massa e volume aumentam conforme aumentam a massa e o volume, o que também gerou dificuldades de compreensão por parte dos alunos desta sala:

\begin{tabular}{|l|l|l|}
\hline \multicolumn{1}{|c|}{ Tempo } & \multicolumn{1}{|c|}{ Discurso } & \multicolumn{1}{|c|}{ Análise } \\
\hline $35: 40$ & $\begin{array}{l}\text { P:O que a gente pode dizer a partir desses resultados? } \\
\text { P:Esses resultados querem dizer o quê? } \\
\text { P:O que eu posso dizer sobre a relação massa volume }\end{array}$ & P3 \\
\hline $35: 53$ & Al4: São proporcionais & N3 (não justifica) \\
\hline $36: 08$ & $\begin{array}{l}\text { P:Como assim são proporcionais? } \\
\text { P:O que ... gente ajudem...vamos determinar o que quer dizer esse } \\
\text { número }\end{array}$ & P3 \\
\hline $36: 13$ & Al: Quanto menor o volume maior a massa (e) & \\
\hline $36: 14$ & P:Quanto menor o volume maior a massa & N3 (e,f,g) \\
\hline $36: 18$ & Al: Não (f) & \\
\hline $36: 28$ & Al1: Quanto maior o volume maior a massa (g) & \\
\hline $36: 35$ & $\begin{array}{l}\text { P:Álquando o volume é maior a massa é maior? } \\
\text { P:É no caso está aumentando né...vamos fazer mais uma }\end{array}$ \\
\hline
\end{tabular}


Ao perceber a dificuldade gerada pelas medidas das amostras de água, a professora pede para que mais dois alunos repitam uma das medidas realizadas por ela; a aluna realiza a medida com $30 \mathrm{~mL}$. A sexta medida não foi registrada no quadro e em nenhum material dos alunos, por esse motivo não consta na tabela 4.5

Tabela 4.5- Medidas de densidade da água

\begin{tabular}{|c|c|c|}
\hline Massa (g) & Volume (mL) & Massa/volume $\mathbf{( g / m L )}$ \\
\hline 27,15 & 30 & 0,905 \\
\hline 36,91 & 40 & 0922 \\
\hline 56,58 & 60 & 0,943 \\
\hline 97,32 & 100 & 0,973 \\
\hline 30,68 & 30 & 1,01 \\
\hline
\end{tabular}

\begin{tabular}{|c|c|c|}
\hline Tempo & Discurso & Análise \\
\hline $42: 26$ & $\begin{array}{l}\text { P:Ah lá... mais uma medida da Al2...que aconteceu agora? } \\
\text { P:Deu igual a da Al1 a massa? }\end{array}$ & P2 (comparação) \\
\hline 42:31 & Al5: Sei lá cada uma tem um jeito de medir (h) & \\
\hline $42: 33$ & $\mathrm{P}:$ Cada uma tem um jeito de que Al5? & \\
\hline 42:37 & Al5: De colocar a água dentro dele (i) & \\
\hline $42: 58$ & $\begin{array}{l}\text { P: Que... presta atenção.....oh olha aqui...presta atenção...eu quero } \\
\text { que vocês entendam o seguinte... porque a Al2 colocou deu uma } \\
\text { massa a AL1 deu outra eu deu outra até... aconteceu o que.... a } \\
\text { massa ficou diferente? } \\
\text { P:A Al5 tava falando ali o jeito do que? }\end{array}$ & \\
\hline 43:16 & Al5: Da forma ..por isso que tá variando (faz com a mão)) (j) & N3 $(h, i, j)$ \\
\hline 43:28 & $\begin{array}{l}\text { P:Então o jeito que a gente lê o volume de água ele tem uma } \\
\text { variação } \\
\text { P:A relação massa volume que apareceu aqui.... a diferença da } \\
\text { relação massa volume que apareceu aqui e grande? }\end{array}$ & P2 (comparação) \\
\hline $43: 43$ & Al: Não & \\
\hline $43: 43$ & Al: Depende & \\
\hline 44:01 & $\begin{array}{l}\text { P:Que vocês acham...zero nove noventa zero noventa e dois zero } \\
\text { noventa e cinco um virgula zero...das que eu fiz vocês acham que } \\
\text { a diferença é uma diferença grande? } \\
\text { P:Será que da para dizer que... } \\
\text { P:O problema da balança..a balança tá errada...qual o problema da } \\
\text { balança...erro? }\end{array}$ & P2 \\
\hline $44: 29$ & $\begin{array}{l}\text { Al: Não } \\
\text { Al6: Variação da balança }\end{array}$ & N3 \\
\hline $44: 35$ & $\begin{array}{l}\text { P:Que fonte a gente tem de variação a gente tem aí? } \\
\text { P:O que pode afetar a minha medida que vai me levar a um } \\
\text { resultado diferente? }\end{array}$ & P2 \\
\hline 44:43 & Al: Variação da balança & \\
\hline $44: 48$ & P:Variação da balança que mais & \\
\hline $44: 51$ & Al: O jeito que lê & $\begin{array}{l}\mathrm{N} 3 \\
\text { (tentativa, relembra) }\end{array}$ \\
\hline 44:53 & $\mathrm{P}: \mathrm{O}$ jeito que a pessoa leu a medida & \\
\hline
\end{tabular}

A professora procura justificar as diferenças das medidas relacionando-as com as variações que podem ocorrer de uma medida para outra ao se alterar o 
operador. A professora desejava, com esse experimento, que os alunos analisassem a tabela e verificassem que os valores da razão massa/volume se aproximavam de zero vírgula nove. Um dos alunos percebe a relação quase no final da aula:

\begin{tabular}{|l|l|l|}
\hline \multicolumn{1}{|c|}{ Tempo } & \multicolumn{1}{|c|}{ Discurso } & \multicolumn{1}{|c|}{ Análise } \\
\hline $45: 22$ & $\begin{array}{l}\text { P:Volta a pergunta ....que eu posso dizer olhando para aqueles } \\
\text { números lá da relação massa volume da água ((silêncio na sala)) }\end{array}$ & P3 \\
\hline $45: 45$ & Al: Zero virgula... & \\
\hline $45: 52$ & P:A relação entre massa e volume é aproximadamente quanto? & P2 \\
\hline $45: 45$ & Al1: Zero virgula nove (l) & P2 \\
\hline $45: 47$ & $\begin{array}{l}\text { P:Deu para perceber isso Al1? } \\
\text { P:Então ela é constante ou ela varia? }\end{array}$ & $\mathrm{N} 4(\mathrm{I}, \mathrm{m})$ \\
\hline $45: 02$ & Al1: Constante $(\mathrm{m})$ & \\
\hline $45: 06$ & P:Ela e constante ou ela varia gente? & \\
\hline $45: 13$ & Al: Constante & \\
\hline
\end{tabular}

Porém, como a aula está praticamente no final, a professora encerra a aula e retoma o conceito da aula seguinte.

\section{Terceira aula}

A professora retoma a aula com a idéia dos alunos de que quanto maior a massa maior a razão massa/volume e pede para que novamente dois alunos repitam a medida de $40 \mathrm{~mL}$ e $60 \mathrm{~mL}$ realizadas por ela. Novamente, ela questiona sobre os valores obtidos e as variações ocorridas:

\begin{tabular}{|l|l|l|}
\hline \multicolumn{1}{|c|}{ Tempo } & \multicolumn{1}{|c|}{ Discurso } & \multicolumn{1}{c|}{ Análise } \\
\hline $07: 21$ & $\begin{array}{l}\text { P:Por que que a medida que o Al1 fez e a AL7 fez não foram } \\
\text { iguaizinhas a mim? }\end{array}$ & $\begin{array}{l}\text { P2 (já havia feito } \\
\text { essa questão } \\
\text { antes) }\end{array}$ \\
\hline $07: 33$ & $\begin{array}{l}\text { Al1: Por que tem diferença olhar assim tipo...às vezes coloca trinta } \\
\text { e não é trinta? }\end{array}$ & $\begin{array}{l}\text { N3 (já não é mais } \\
\text { problema é } \\
\text { exercício) }\end{array}$ \\
\hline $07: 40$ & P:Tem diferença aonde na leitura do volume que mais? & \\
\hline $07: 51$ & Al1: Balança & N2 \\
\hline $07: 55$ & $\begin{array}{l}\text { P:Da...balança } \\
\text { P:Então a gente tem a variação da balança e a variação } \\
\text { do...volume }\end{array}$ & \\
\hline $08: 05$ & $\begin{array}{l}\text { P:Então olha pra mim } \\
\text { P:O quarenta deu noventa e dois e deu noventa e cinco...o } \\
\text { sessenta deu noventa e quatro e noventa e oito...em qual } \\
\text { algarismo eu estou tendo a variação? }\end{array}$ & P2 (comparação) \\
\hline $08: 28$ & Ah: Hum? & \\
\hline $08: 34$ & Al: O segundo (a) & \\
\hline $08: 38$ & P:O segundo depois da... & N3 (a,b) \\
\hline $08: 40$ & Al: Da vírgula (b) & \\
\hline $08: 47$ & P: A minha variação experimental está aonde? & \\
\hline $08: 56$ & $\begin{array}{l}\text { P:Nas duas últimas casas depois da vírgula...moçada qualquer } \\
\text { variação...qualquer não...mas variações aqui a gente teve três } \\
\text { algarismos...no sessenta a gente teve quatro algarismos } \\
\text { P:Então variações de três ou quatro nas duas últimas casas...o que }\end{array}$ & \\
\hline
\end{tabular}




\begin{tabular}{|l|l|l|}
\hline & $\begin{array}{l}\text { significa? } \\
\text { O que eu atribuo essa variação? }\end{array}$ & \\
\hline $09: 25$ & Al 1: A balança & \\
\hline $09: 29$ & P:A balança e a medida da proveta & \\
\hline
\end{tabular}

A seguir, ela volta a questionar os alunos sobre a relação que poderia ser estabelecida com a tabela:

\begin{tabular}{|l|l|l|}
\hline \multicolumn{1}{|c|}{ Tempo } & \multicolumn{1}{|c|}{ Discurso } & \multicolumn{1}{|c|}{ Análise } \\
\hline 09:35 & $\begin{array}{l}\text { P:Eu volto a perguntar a vocês...a divisão o resultado da divisão da } \\
\text { massa pelo volume...que conclusão eu chego olhando aquela } \\
\text { tabela? }\end{array}$ & P3 \\
\hline $09: 53$ & $\begin{array}{l}\text { Al2: Que a relação massa volume é igual a zero virgula nove } \\
\text { P:Que a relação massa dividida pelo volume é igual...a } \\
\text { aproximadamente zero vírgula nove } \\
\text { P:A conclusão que a gente acabou..a fala que a gente terminou a } \\
\text { aula passada ela precisa ser rediscutida }\end{array}$ & $\mathrm{N} 4$ \\
\hline
\end{tabular}

Percebendo a dificuldade, a professora realiza o experimento utilizando álcool. Os valores utilizados estão na tabela 4.6 a seguir.

Tabela 4.6- Medidas de densidade do álcool

\begin{tabular}{|c|c|c|}
\hline Massa (g) & Volume $(\mathbf{m L})$ & Massa/volume $\mathbf{( g / m L )}$ \\
\hline 23,68 & 30 & 0,786 \\
\hline 31,53 & 40 & 0,788 \\
\hline 46,91 & 60 & 0,781 \\
\hline 78,26 & 100 & 0,782 \\
\hline 30,13 & 40 & 0,753 \\
(Aluno) & & \\
\hline
\end{tabular}

Os mesmos volumes utilizados para a água foram repetidos com o álcool, e um aluno repetiu uma das medidas realizadas pela professora.

Com essas medidas, a professora discute com os alunos o fato de que uma outra pessoa realizar a última medida pode ter contribuído para a pequena diferença nos valores, e então retoma a questão da primeira aula:

\begin{tabular}{|l|l|l|}
\hline \multicolumn{1}{|c|}{ Tempo } & \multicolumn{1}{|c|}{ Discurso } & \multicolumn{1}{|c|}{ Análise } \\
\hline $22: 10$ & $\begin{array}{l}\text { P:A gente começou a aula...a gente consegue identificar material } \\
\text { pela massa? }\end{array}$ & P2 \\
\hline $22: 22$ & Al: Não & N2 \\
\hline $22: 26$ & $\begin{array}{l}\text { P:Não consegue...a gente consegue identificar material pelo } \\
\text { volume? }\end{array}$ & P2 \\
\hline $22: 30$ & Al: Não & N2 \\
\hline $22: 34$ & $\begin{array}{l}\text { P:Dez mL vocês sabem qual material é? } \\
\text { P:Agora eu consigo identificar um material pela relação massa }\end{array}$ & P3 \\
\hline
\end{tabular}




\begin{tabular}{|l|l|l|}
\hline & volume? & \\
\hline $22: 53$ & P:Sim ou não? & \\
\hline $22: 55$ & Al: Sim & \\
\hline $22: 58$ & Al1: Se você souber a relação massa volume de diversos materiais & N4 \\
\hline
\end{tabular}

A aluna analisa as variáveis do problema, compreendendo que, se conhecer a relação massa/volume de diversos materiais, é possível identificar um material.

A professora, então, desafia os alunos questionando o que acontecerá se misturar metade de álcool e metade de água, exigindo que os alunos avaliem as condições para generalizar o conceito:

\begin{tabular}{|l|l|l|}
\hline \multicolumn{1}{|c|}{ Tempo } & \multicolumn{1}{|c|}{ Discurso } & \multicolumn{1}{|c|}{ Análise } \\
\hline $26: 26$ & $\begin{array}{l}\text { P:O que vai acontecer se eu misturar cinqüenta } \mathrm{mL} \text { de água e } \\
\text { cinqüenta } \mathrm{mL} \text { de álcool? }\end{array}$ & P3 \\
\hline $26: 33$ & Al4 : Dá zero vírgula oito (c) & \\
\hline $26: 35$ & P:Quanto tem que dar? & \\
\hline $26: 37$ & Al8: Dá zero virgula oito (d) & \\
\hline $26: 40$ & P:Por que zero vírgula oito Al8? & N4 (c,d,e) \\
\hline $26: 44$ & Al8: Dá mais ou menos a metade (e) & \\
\hline $26: 47$ & P:Mais ou menos a metade & \\
\hline
\end{tabular}

Com o auxílio da professora, os alunos conseguem elaborar com maior clareza as suas idéias, exibindo habilidades cognitivas de alta ordem, classificadas como N4, pois analisam as variáveis do problema, ou seja, as duas relações massa e volume, e sugerem, acertadamente, a solução para o problema.

Porém, quando a professora faz o experimento com metade do volume de álcool e metade de água, o valor da relação massa/volume obtido foi 0,9015 g/mL, muito próximo ao valor da água. Ela, então, realiza outra medida com $70 \mathrm{~mL}$ de álcool e $30 \mathrm{~mL}$ de água, e o valor obtido foi $0,8 \mathrm{~g} / \mathrm{mL}$. Mas, a professora não faz uma discussão mais aprofundada sobre esses valores.

É importante verificar que, nas três vezes nas quais a professora realiza as medidas, ela expressa os valores para a razão massa/volume com muitos algarismos significativos, conforma mostram as tabelas 4.4, 4.5 e 4.6, o que pode ter contribuído para a dificuldade dos alunos em compreenderem os valores obtidos. Talvez, se a professora tivesse utilizado adequadamente (considerando as medidas de massa e de volume) e discutido com os alunos a importância desses algarismos desde a primeira aula, poderia ter facilitado a aceitação de que a razão massa/volume é constante. 


\section{Quarta aula}

Esta aula, assim como a aula da primeira série I, teve duração de apenas vinte minutos pois o restante foi utilizado para a realização do experimento pelos alunos.

A professora inicia a aula definindo o conceito massa/volume, pois até o momento ela não havia nomeado densidade.

A professora espera que, com o experimento do ovo, os alunos consigam utilizar os dados obtidos até o momento para avaliar porque o ovo bóia na água com sal, propondo para isto, questões P3:

\begin{tabular}{|l|l|l|}
\hline \multicolumn{1}{|c|}{ Tempo } & \multicolumn{1}{|c|}{ Discurso } & \multicolumn{1}{|c|}{ Análise } \\
\hline $02: 21$ & $\begin{array}{l}\text { P:Eu posso dizer que a relação massa volume da água ...que a } \\
\text { densidade da água é diferente da densidade da água com sal? }\end{array}$ & $\begin{array}{l}\text { P2 (aplicação de } \\
\text { conceito) }\end{array}$ \\
\hline $02: 31$ & $\begin{array}{l}\text { P:Que vocês acham? } \\
\text { P:Sim ou não? } \\
\text { P:Então eu adicionar sal na água muda a relação massa e volume } \\
\text { por que muda a ... }\end{array}$ & P3 \\
\hline $02: 43$ & $\begin{array}{l}\text { Al: Massa } \\
\text { P:A massa...outra coisa... } \\
\text { P:Vocês acham que a adição de sal vai aumentar ou diminuir a } \\
\text { relação massa volume? }\end{array}$ & P3 \\
\hline $02: 55$ & $\begin{array}{l}\text { Al: Aumentar (a) } \\
\text { P:Aumentar por quê? }\end{array}$ & \\
\hline $02: 59$ & $\begin{array}{l}\text { Al1: Porque eu tenho mais massa (b) } \\
\text { P:Então eu posso dizer que a densidade...é maior ((escreve no } \\
\text { quadro)) } \\
\text { P:Tudo bem até aqui? }\end{array}$ & N4 \\
\hline $03: 03$ & \\
\hline
\end{tabular}

Após adicionar o sal:

\begin{tabular}{|l|l|l|}
\hline \multicolumn{1}{|c|}{ Tempo } & \multicolumn{1}{|c|}{ Discurso } & \multicolumn{1}{|c|}{ Análise } \\
\hline $07: 58$ & $\begin{array}{l}\text { P:Por que o ovo flutua na água com sal e não flutua na água por } \\
\text { quê? }\end{array}$ & P3 \\
\hline $08: 09$ & $\begin{array}{l}\text { AL8: Porque a água com sal fica mais densa do que a água normal } \\
08: 12\end{array}$ & $\begin{array}{l}\text { P:Por que a água com sal fica mais densa do que a água normal e } \\
\text { ai? }\end{array}$ \\
\hline $08: 30$ & $\begin{array}{l}\text { P:Oh então a flutuação presta atenção a flutuação tem a ver com a } \\
\text { densidade? }\end{array}$ & \\
\hline $08: 39$ & Al: Tem & \\
\hline
\end{tabular}

Por fim, a professora explica para os alunos o que deve ser feito no experimento e pede para que os grupos sejam formados. 
Nas figuras 3 e 4 são apresentados os níveis das questões propostas pela professora e suas freqüências e os níveis das respostas dos alunos e suas freqüências respectivamente:

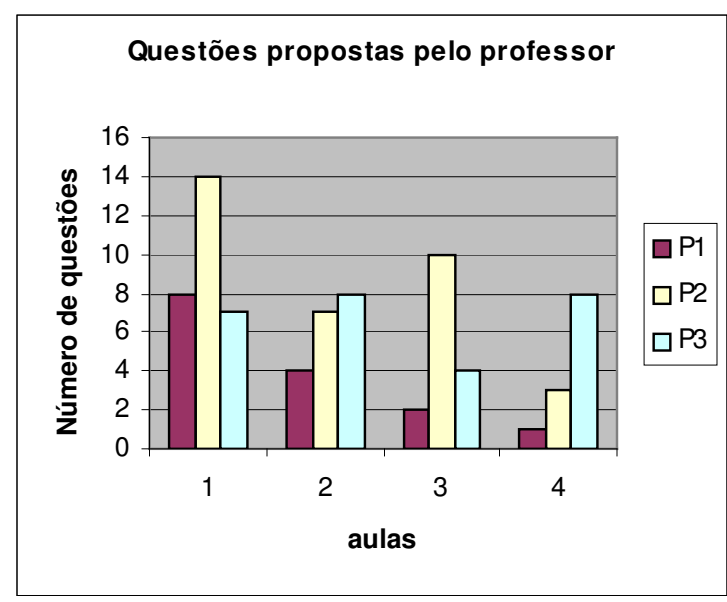

Figura 3. Nível de cognição das questões propostas pelo professor

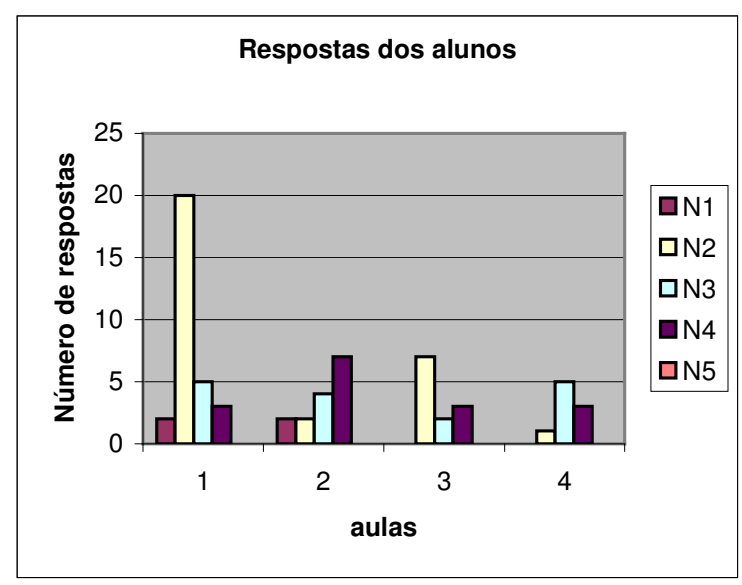

Figura 4. Nível cognitivo das respostas dos alunos

Observa-se que na primeira aula as questões propostas pela professora foram classificadas em maior número no nível P2, conforme ocorreu também na Primeira Série I. O objetivo desta aula era conceituar massa e volume utilizando-se experimentos demonstrativos, assim as questões propostas pela professora exigiam comparação e aplicação de leis e conceitos. Com relação às respostas dos alunos, observa-se um elevado número de respostas classificadas no nível N2, pois muitas vezes as questões da professora exigiam comparações e os alunos respondiam sem identificação de variáveis ou sem justificativas condizentes com o problema proposto, exibindo respostas pontuais e muitas vezes monossilábicas. A fim de não se criar subjetivismos, considerou-se apenas se o aluno havia compreendido o problema.

As respostas classificadas como N4 na primeira aula se referem às hipóteses elaboradas pelos alunos para solucionar o problema proposto pela professora para identificar um material.

É importante relatar que a professora iniciou a seqüência de aulas sobre o conceito de densidade com a Primeira Série II antes de iniciar com a primeira série I. A segunda aula da Primeira Série II ocorreu quase duas semanas após primeira aula, o que pode ter contribuído para o baixo número de resposta N3 e N4, uma vez que a professora teve que retomar alguns conceitos com a série II. 
$\mathrm{Na}$ segunda aula, quando a professora faz o experimento das medidas de volume de água, os alunos precisam avaliar os dados a fim de chegarem a uma possível resposta para o problema de que a relação massa/volume da água é uma constante. Assim, as questões propostas pela professora exigem comparações (P2), mas grande parte delas exigem que os alunos avaliem os dados e proponham hipóteses para a solução do problema (P3). Grande parte do tempo foi empregado na realização das medidas, e não se observa manifestação de habilidades cognitivas pelos alunos, somente leitura das medidas.

$\mathrm{Na}$ terceira aula grande parte das questões propostas pela professora ainda foi classificada como P2, talvez pelo fato das aulas terem ficado fragmentadas, pois os experimentos para a investigação da massa e volume, da relação massa/volume da água e do álcool aconteceram separadamente e os alunos não tiveram a mesma oportunidade que os alunos da outra série de evidenciar os fatos e analisarem os dados podendo refletir sobre os outros obtidos até o momento. Há um baixo número de respostas N3 e N4.

É importante relatar que não se pretende realizar uma comparação entre as duas salas, pois mesmo se tratando de uma mesma metodologia utilizada por uma mesma professora, os alunos são outros e a seqüência de aulas ocorreu em intervalos de tempo diferentes. Porém, pode-se fazer uma aproximação entre as duas salas para reavaliar os dados.

As aulas dois e três da Primeira Série II acontecem na mesma seqüência e, praticamente, da mesma maneira que a segunda aula da Primeira Série I; até mesmo os erros de medidas aconteceram nas duas salas. Com relação às questões propostas pela professora não há diferenças significativas, pois se trata da mesma seqüência de aulas ministradas pela mesma professora. Porém, se somarmos as respostas dos alunos nas aulas dois e três e compararmos com as respostas dadas pelos alunos da Série I, na segunda aula, as diferenças diminuem. O número total de respostas classificadas como N4, na qual o aluno elabora uma hipótese ou avalia os dados, é significante quando comparada com a outra série. Porém, o número de respostas N2 supera o de respostas N3, talvez, como já dito, pelo fato de as aulas terem ficado fragmentadas e a professora muitas vezes precisar retomar algum conceito.

É preciso considerar a importância do planejamento da seqüência de aulas pela professora, de modo a criar momentos nos quais os alunos possam elaborar os seus raciocínios. Entretanto, a professora também precisa refletir sobre o andamento da aula para, diante de possíveis dificuldades apresentadas pelos alunos, re- 
planejar a aula para facilitar o entendimento dos alunos, mas com o cuidado de não criar ainda mais obstáculos conceituais.

$\mathrm{Na}$ última aula, quando a professora realiza o experimento do ovo, os resultados são bem semelhantes nas duas salas, com a diferença que na Série II não houve respostas algorítmicas (N1). As questões propostas pela professora foram, em sua maioria, classificadas como P3, pois algumas respostas dadas pelos alunos geravam novas questões de maior exigência cognitiva ou até mesmo, algumas questões feitas pelos alunos eram reelaboradas pela professora e sugeridas para os alunos. Na outra sala a professora utilizou grande parte do tempo discutindo o experimento e explicando o funcionamento do densímetro. Porém, o número total de respostas dos alunos da Série II ainda é menor se comparado com o número total de respostas da Série I, mas quando comparadas em freqüência de níveis cognitivos, as duas salas praticamente se equiparam, ou seja, a série II apresentou um número de respostas igual a 1/3 do total de respostas da Serie I, porém, quando se comparam as freqüências dos níveis cognitivos, as duas salas são muito semelhantes.

\section{O Pós- Laboratório}

Ao iniciar a aula, a professora questiona quanto à facilidade ou dificuldade em analisar as amostras:

\begin{tabular}{|l|l|l|}
\hline \multicolumn{1}{|c|}{ Tempo } & \multicolumn{1}{|c|}{ Discurso } & \multicolumn{1}{|c|}{ Análise } \\
\hline $14: 06$ & $\begin{array}{l}\text { P:A pergunta lá..as densidades elas permitiram ...a identificação } \\
\text { das amostras sólidas? }\end{array}$ & P2 (comparação) \\
\hline $14: 14$ & Al: Sim & \\
\hline $14: 21$ & $\begin{array}{l}\text { P:Por que? } \\
\text { P:Foi fácil ...deu para comparar? }\end{array}$ & \\
\hline $14: 22$ & Al: Deu & \\
\hline $14: 30$ & $\begin{array}{l}\text { P:Deu para comparar tranqüilo? } \\
\text { P:Bateu olhou a determinação sua a de vocês olharam para a } \\
\text { tabela foi fácil imediato? }\end{array}$ & \\
\hline $14: 37$ & $\begin{array}{l}\text { Al1: foi um pouco difícil porque o valor que a gente tirou lá não deu } \\
\text { exatamente isso }\end{array}$ & N3 \\
\hline $14: 45$ & P:No foi só olhar e imediatamente chegar à conclusão & \\
\hline $15: 07$ & P:Como é que vocês fizeram? & N3 \\
\hline $15: 09$ & Al1: O mais próximo & \\
\hline
\end{tabular}

Porém, a professora explica porque os valores foram aproximados, não permitindo que os alunos elaborem suas próprias hipóteses: 


\begin{tabular}{|c|c|c|}
\hline Tempo & Discurso & Análise \\
\hline $21: 48$ & $\begin{array}{l}\text { P:Só... assim...o que mais pode ter feito com que a densidade que } \\
\text { a gente calculou não fosse a mesma que não era exatamente essa } \\
\text { que tava na tabela? }\end{array}$ & P3 \\
\hline $21: 56$ & $\begin{array}{l}\text { P:Deixa eu contar para vocês...essa densidade dos sólidos eu tirei } \\
\text { do manual que tem densidade de vários materiais } \\
\text { P:Então a gente tem lá o manual e tem densidade do ferro do } \\
\text { cobre do zinco do alumínio vários metais vários materiais } \\
\text { P:Então é uma densidade padrão eu tirei de lá...Por que vocês } \\
\text { acham além desses fatores experimentais que vocês falaram } \\
\text { P:O que mais que pode ter feito com que a densidade determinada } \\
\text { não fosse exatamente aquela? }\end{array}$ & \\
\hline $22: 33$ & Al: Da divisão & N2 \\
\hline $22: 35$ & Al: Do cálculo & N2 \\
\hline $22: 42$ & $\begin{array}{l}\text { P:Tá só que o cálculo algum erro do cálculo } \\
\text { P:A variação Al era muito grande então assim houve amostras de } \\
\text { cobre que a densidade dava sete e a densidade do cobre é oito } \\
\text { vírgula noventa e dois houve a mostras de chumbo que a } \\
\text { densidade deu nove e a densidade do chumbo é onze virgula três }\end{array}$ & \\
\hline 23:08 & Al: Tá amassado? & N2 \\
\hline 23:12 & $\begin{array}{l}\text { P:Será que estar amassado vai alterar tanto a densidade } \\
\text { P:A mudança do formato será que justifica? }\end{array}$ & \\
\hline 23:31 & Al: Espirra água & $\mathrm{N} 2$ \\
\hline 23:33 & Al:Espirra água tá bom.. & \\
\hline 23:35 & Al8: Variação da balança & $\mathrm{N} 2$ \\
\hline $23: 40$ & $\begin{array}{l}\text { P:O Al8 falou aqui variação da balança....mas a variação é muito } \\
\text { grande } \\
\text { P:Ajuda a pensar vai...vou dar uma dica...a densidade da tabela é } \\
\text { assim densidade do COBRE densidade de ALUMïNIO densidade } \\
\text { do CHUMBO } \\
\text { P:E as amostras da gente? }\end{array}$ & P3 \\
\hline $24: 29$ & $\begin{array}{l}\text { P:A gente determinou as densidades do quê? } \\
\text { P:Se a densidade que a gente determinou não era igualzinha } \\
\text { idêntica a densidade do cobre o que será que pode ter na nossa } \\
\text { amostra? }\end{array}$ & \\
\hline $24: 40$ & Al9: Interferente & N3 (não justifica) \\
\hline $24: 42$ & $\begin{array}{l}\text { P:Isso Al9 muito bem...a Al9 tá falando o seguinte que nas nossas } \\
\text { amostras eu posso não ter exatamente o cobre...o que eu posso } \\
\text { ter..um outro material qualquer que não tenha a mesma densidade } \\
\text { do cobre } \\
\text { P:O que é alterado o que ia acontecer com a mistura..ela ia ter a } \\
\text { mistura tem a mesma densidade do material sozinho? }\end{array}$ & P2 \\
\hline $25: 18$ & P:A água com sal tem a mesma densidade que a água? & \\
\hline $25: 20$ & Al:Não & N2 \\
\hline $25: 24$ & $\begin{array}{l}\text { P:Então o que acontece gente no caso do alumínio e no caso do } \\
\text { zinco as densidades que vocês determinaram foram muito } \\
\text { próxima a essas da tabela...dois ponto cinco dois ponto três } \\
\text { P:São próximas a esses valores essas determinações? } \\
\text { P:No caso do alumínio e no caso do zinco as densidades que } \\
\text { vocês determinaram são próximas ao valor da tabela } \\
\text { P:Então o que significa que as minhas amostras são o quê? }\end{array}$ & P3 \\
\hline 26:06 & Al: Semelhantes & N3 \\
\hline $26: 09$ & P:São o que? & \\
\hline $26: 10$ & Al: Semelhantes & \\
\hline $26: 16$ & $\begin{array}{l}\text { P:Semelhantes às? } \\
\text { P:São mais puras né gente...e no caso do cobre que deu bastante } \\
\text { diferente do chumbo? }\end{array}$ & $\mathrm{P} 2$ \\
\hline $26: 22$ & Al: Estão misturadas & N3 \\
\hline $26: 25$ & $\mathrm{P}$ :Elas estão misturadas a um outro metal & \\
\hline
\end{tabular}


A professora não permite que o aluno elabore a suas respostas, ela mesma conclui o raciocínio do aluno, não permitindo que ele expresse suas idéias.

A professora explica que a identificação dos materiais líquidos foi mais fácil pois a tabela padrão foi feita com os mesmos materiais analisados e não com valores da literatura, conforme foi elaborada a tabela dos sólidos.

Assim, os alunos não têm a oportunidade de explorar conceitualmente os dados experimentais coletados, reduzindo as potencialidades desta etapa da atividade em promover a manifestação de habilidades cognitivas.

$\mathrm{Na}$ discussão pós-laboratório, a professora propôs 19 questões para discussão com a classe. Destas questões, 11 foram classificadas no nível P3 e oito no nível P2. Evidencia-se um elevado número de questões P3 pois a professora exige que os alunos utilizem os dados obtidos para avaliar as condições e propor hipóteses para solucionar o problema investigado no laboratório. A maior parte das respostas dos alunos foi classificada no nível N3 (11 respostas) pois, na maioria delas, os alunos entendem o problema, identificam as variáveis mas não as analisam relacionando com os dados e os conceitos norteadores. Duas respostas evidenciaram elaboração de hipóteses ou raciocínios mais complexos para a resolução das questões propostas pela professora, exibindo habilidades cognitivas relativas ao nível N4 e 7 respostas foram classificadas no nível N3.

\subsubsection{Questões escritas}

A escrita como instrumento no processo ensino e aprendizagem possibilita ao aluno expressar suas idéias e concepções acerca dos fenômenos químicos de maneira mais estruturada e consolidada, uma vez que escrever exige habilidades de síntese e interação dos conhecimentos demandando maior esforço cognitivo.

Conforme argumentam Rivard e Straw (2000), o uso da escrita, juntamente com a discussão de idéias, pode contribuir muito mais para um aumento da aprendizagem do que se essas modalidades fossem utilizadas isoladamente.

Esses autores ainda salientam a importância da discussão e da escrita juntamente com o trabalho prático nas aulas de Ciências. 


\section{Análise dos protocolos}

Para a realização do experimento no laboratório foram formados seis grupos em cada sala. Os grupos eram formados, aproximadamente, por cinco ou seis alunos em cada. Foram então coletados doze protocolos, porém, três não puderam ser analisados, pois não apresentavam respostas completas e condizentes. Ao analisar os protocolos da primeira série I, foram contabilizados 25 alunos que participaram da atividade experimental e entregaram os materiais; sete destes alunos fazem parte de dois grupos dos quais os materiais foram desconsiderados na análise. Da primeira série II, foram contabilizados 28 alunos e apenas um deles entregou o protocolo separadamente, o qual não foi analisado. É importante recordar que cada sala era composta por aproximadamente trinta alunos.

Durante o experimento, os alunos, em grupos, tinham como objetivo calcular as densidades de sólidos e líquidos com o auxílio do protocolo, e comparar seus dados com os valores de densidades contidos em uma tabela "padrão". Simultaneamente, deveriam responder a algumas questões contidas no protocolo de investigação. Das quatro questões propostas pelo professor, consideradas para análise, duas foram classificadas no nível P2 de cognição (questão 1 e 3) e as outras duas pertencem ao nível P3 de cognição (questão 2 e 4).

Apresentam-se, a seguir, as questões propostas pela professora durante a atividade experimental e a análise segundo o nível de cognição exigido e algumas respostas dadas pelos alunos e sua respectiva categorização. Serão apresentadas as respostas dos alunos das duas séries. Essa interpretação foi elaborada analisando as correções feitas pela professora no material escrito dos alunos e também em conversa com a professora:

\section{Questões relacionadas à densidade de sólidos}

Questão 1: A densidade permitiu a identificação das amostras recebidas? Por quê? P2 : é preciso analisar as possibilidades da densidade permitir a identificação, aplicação do conceito.

Resposta esperada pela professora: Sim, pois havia uma "tabela padrão" com os valores das densidades dos materiais obtidos em literatura, e também, é preciso considerar que os alunos tinham que investigar apenas três sólidos, diminuindo a possibilidade de erros na comparação dos valores obtidos com os da tabela. 
Porém, os valores obtidos pelos alunos não foram exatamente iguais aos da "tabela" ocasionando na comparação dos valores e identificação dos materiais por aproximação de densidades .

\section{Respostas}

Grupo 1

Mais ou menos, porque em alguns casos a densidade desejada não foi encontrada na tabela.

N2: Utilizou a aproximação dos resultados. Compreende o problema. Identificou a variável (as densidades deram aproximadas). Identificou processo de controle, ou seja não foi totalmente suficiente pois as medidas não foram iguais.

\section{Grupo 5}

Sim, pois a densidade de cada material na tabela se aproximou dos resultados obtidos N3 : Estabelece processos de controle de variáveis.

Questão 2: Você poderia utilizar esse mesmo procedimento para determinar a densidade de uma amostra de sal de cozinha? Por quê?

P3: é preciso utilizar os dados e os conceitos para avaliar condições (outra situação, sal de cozinha) e generalizar o conhecimento.

Resposta esperada pela professora: Não, pois o sal se dissolveria, não sendo possível medir o deslocamento do volume pela adição do sólido.

Nesta questão, 7 dos 9 grupos analisados responderam que a dissolução do sal impediria a determinação da densidade e não a impossibilidade de determinação do volume final.

\section{Respostas}

\section{Grupo 1}

Não, porque o sal de cozinha quando fosse misturado com a água se dissolveria.

N3: Identificou a variável (dissolve) mas não estabelece relação entre o dissolver e a impossibilidade de medir o volume.

\section{Grupo 3}

Sim, porque conseguimos medir a massa do sal e ao colocá-lo na água o volume aumentará permitindo calcular o volume do sal.

N1: Não compreendeu o problema.

\section{Questões relacionadas à densidade de líquidos}

Questão 3: A densidade permitiu a identificação das amostras recebidas? Por quê? P2: $\dot{E}$ preciso utilizar o conhecimento construído nas atividades anteriores para analisar, comparar e aplicar conceitos que sejam suficientes para a resposta. 
Resposta esperada pela professora: Sim, pois havia uma "tabela padrão" com os valores das densidades dos materiais obtidos em literatura, e também, é preciso considerar que, os alunos tinham que investigar apenas três sólidos, diminuindo a possibilidade de erros na comparação dos valores obtidos com o da tabela.

Novamente, os valores obtidos pelos alunos não foram exatamente iguais aos da "tabela", ocasionando a comparação dos valores e identificação dos materiais por aproximação de densidades.

\section{Respostas}

\section{Grupo 1}

Com a densidade é possível identificar as amostras que recebemos porque o valor que obtivemos com os densímetros foi possível comparar com a tabela que mostrava o valor de cada uma das amostras.

N3 : Estabelece processos de controle de variáveis

\section{Grupo 4}

Sim , pois era parecido com as medidas da tabela e tinham poucos resultados na tabela.

N4: Analisou as variáveis e suas relações causais, ou seja só foi possível identificar pois só tinham aquelas três possibilidades. Se houvessem mais materiais com valores próximos não seria possível.

Questão 4 :A densidade sempre poderá ser utilizada para identificar um material? Por quê? P3: Possibilita ao aluno generalizar, avaliar condições de contorno e propor hipóteses.

Resposta esperada pela professora: Não pois podem existir materiais com a mesma densidade, ou tão próximos podendo prejudicar a identificação correta. Não é suficiente.

\section{Respostas:}

\section{Grupo 5}

Não, pois dois materiais diferentes podem ter a mesma densidade.

N3: Identificaram variáveis e processos de controle, mas não analisaram as relações causais

\section{Grupo 1}

Nem sempre poderá ser utilizada a densidade para identificar um material pois tem material que poderá ter a densidade parecida, para identificar um material é preciso de outros meios para ter uma identificação certa, ou seja, sem dúvidas que seja outro material.

No nosso caso (neste experimento) foi possível a identificação pois tinha poucos materiais, mas no mundo para identificar um material não basta somente a densidade.

N4: Analisou e avaliou as relações causais, até mesmo sugeriu resolução para o problema propondo a utilização de outros métodos para a identificação. 
A figura 5 apresenta as respostas dos nove grupos analisados:

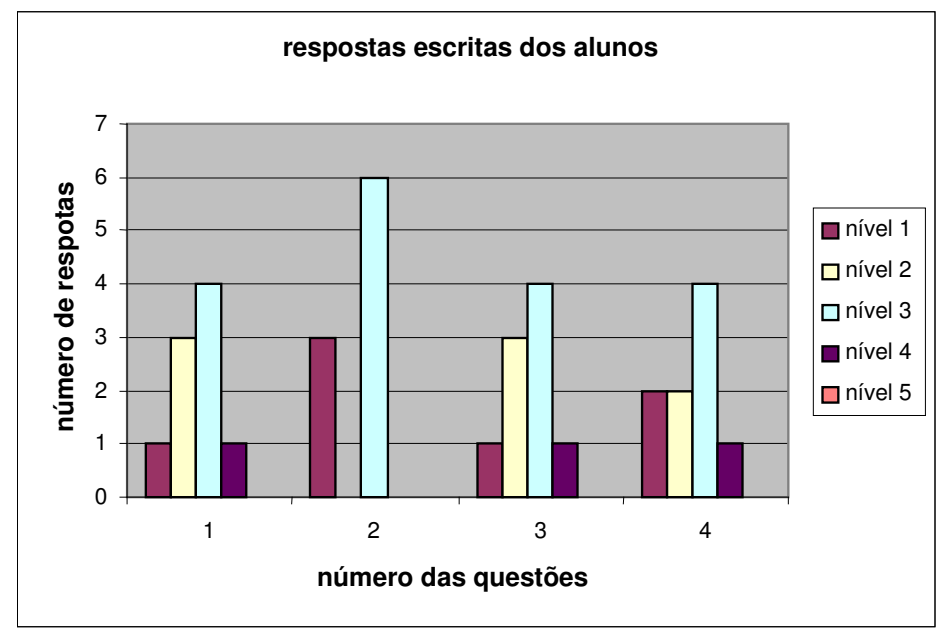

Figura 5. Nível de cognição das respostas escritas dos alunos

Dos nove grupos analisados, a maior parte das respostas enquadra-se no nível três de habilidades cognitivas, e apenas três delas no nível quatro. A questão 2, classificada como nível P3 de exigência do professor, mostrou que os alunos elaboraram respostas categorizadas no nível N1 ou N3. Essa questão exigia que os alunos apresentassem a capacidade de relacionar a impossibilidade de medir o volume final de um sólido dissolvido em água para determinar sua densidade. Nenhum grupo conseguiu explicar satisfatoriamente a questão, não exibindo a capacidade de analisar as variáveis e suas relações causais, ou seja, que ao dissolver o sal seria impossível medir o volume final do sólido. Os grupos classificados no nível N1 não compreenderam o problema.

Das três respostas classificadas no nível N4, duas pertencem ao mesmo grupo, o que evidencia que os outros grupos não conseguiram avaliar todas as condições necessárias para a resolução do problema experimental. Este grupo pertence à Primeira Série II.

Ao analisar as respostas separadamente por sala verifica-se que, das sete questões classificadas como N1, cinco pertencem a grupos da Primeira Série II; um número elevado quando comparado ao desempenho das duas salas nas aulas de demonstração investigativa. Das questões classificadas no nível N3, 11 respostas foram elaboradas por alunos também da Primeira Série II. Porém, realizar essa análise comparativa não é tão simples, uma vez que o ambiente de aprendizagem é 
outro, os alunos estão em grupos e não estão contando com o auxílio da professora para guiar os seus raciocínios. A professora permanece em sala de aula para auxiliar no desenvolvimento manipulativo dos experimentos, mas não se envolve na análise de dados e conclusões dos alunos, o que ocorre na aula pós-laboratório, quando a professora discute os resultados com toda a sala.

Ao finalizar as aulas, a professora elaborou algumas questões para revisão e fechamento do assunto (Anexo D), a fim de avaliar a aprendizagem dos alunos com relação ao conceito. Apresentam-se a seguir, as três questões propostas pela professora e algumas respostas dos alunos analisadas segundo os referenciais desta pesquisa.

\section{Questão proposta pela professora}

Questão 1: A densidade pode ser utilizada para auxiliar na identificação de um material? Por quê?

P2 : Aplicar conceitos para explicar o problema

\section{Respostas dos alunos}

\begin{tabular}{|l|l|l|}
\hline \multicolumn{1}{|c|}{ Alunos } & \multicolumn{1}{|c|}{ Respostas } & \multicolumn{1}{c|}{ Análise } \\
\hline Aluno 3 & $\begin{array}{l}\text { Sim, pois toda massa e volume } \\
\text { precisa ser igual }\end{array}$ & $\mathrm{N} 1$ \\
\hline Aluno 2 & $\begin{array}{l}\text { Sim, porque se o material for } \\
\text { totalmente puro a densidade não } \\
\text { se altera }\end{array}$ & $\mathrm{N} 3$ \\
\hline
\end{tabular}

\section{Questão proposta pela professora}

Questão 2 : Por que um material flutua em outro?

P2: Aplicar conceitos para explicar o problema

Respostas dos alunos

\begin{tabular}{|l|l|l|}
\hline \multicolumn{1}{|c|}{ Alunos } & \multicolumn{1}{c|}{ Respostas } & \multicolumn{1}{c|}{ Análise } \\
\hline Aluno 3 & $\begin{array}{l}\text { Por causa da concentração das } \\
\text { massas }\end{array}$ & N2 \\
\hline Aluno 2 & $\begin{array}{l}\text { Um material flutua em outro } \\
\text { quer dizer que ele é menos } \\
\text { denso que o outro }\end{array}$ & N3 \\
\hline
\end{tabular}

\section{Questão proposta pela professora}

Questão 3 : Sabendo que o gelo flutua na água, discuta se a temperatura pode ou não afetar a densidade de um material? P3: Avaliar condições, propor hipóteses 
Respostas dos alunos

\begin{tabular}{|l|l|l|}
\hline \multicolumn{1}{|c|}{ Alunos } & \multicolumn{1}{|c|}{ Respostas } & \multicolumn{1}{c|}{ Análise } \\
\hline Aluno 3 & $\begin{array}{l}\text { Sim, pode afetar, pois se a água } \\
\text { estiver quente, o gelo derrete } \\
\text { mais fácil, e logo sua densidade } \\
\text { diminui }\end{array}$ & $\mathrm{N} 1$ \\
\hline Aluno 2 & $\begin{array}{l}\text { Quer dizer que o gelo é menos } \\
\text { denso do que a água por isso } \\
\text { que ele flutua na água }\end{array}$ & $\begin{array}{l}\text { N2 (não se refere à } \\
\text { temperatura) }\end{array}$ \\
\hline Aluno 6 & $\begin{array}{l}\text { A temperatura pode influenciar, } \\
\text { porque o gelo possui o mesmo } \\
\text { material do que a água, só que } \\
\text { em baixa temperatura }\end{array}$ & $\mathrm{N} 4$ \\
\hline
\end{tabular}

Das três questões propostas pela professora, duas foram classificadas no nível P2 (questão 1 e 2) e uma no nível P3 (questão 3). Os níveis cognitivos das respostas dos alunos da primeira série I são apresentados na figura 6 , e na figura 7 são apresentadas as respostas dos alunos da série II:

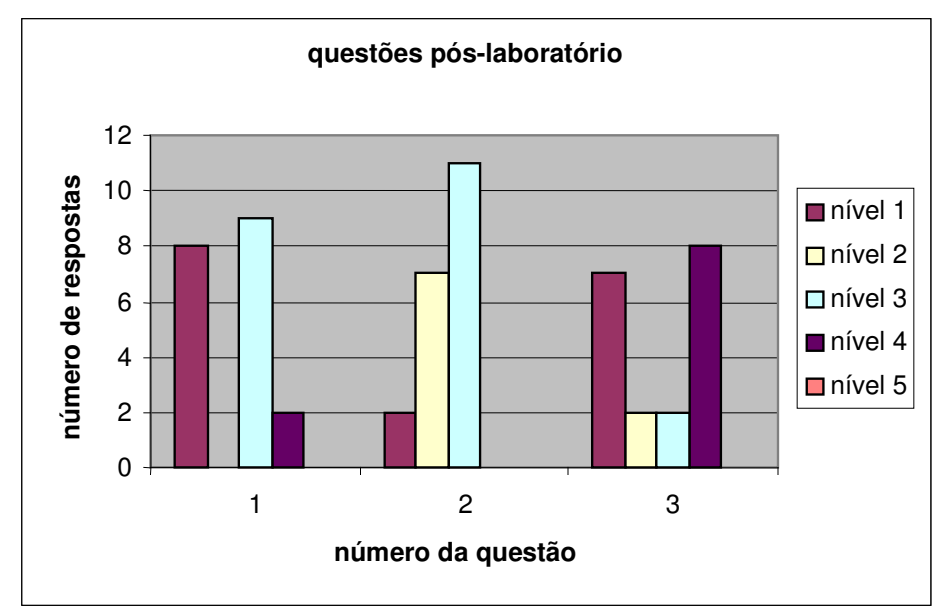

Figura 6. Nível de cognição das respostas dos alunos na aula pós-laboratório da Primeira Série I 


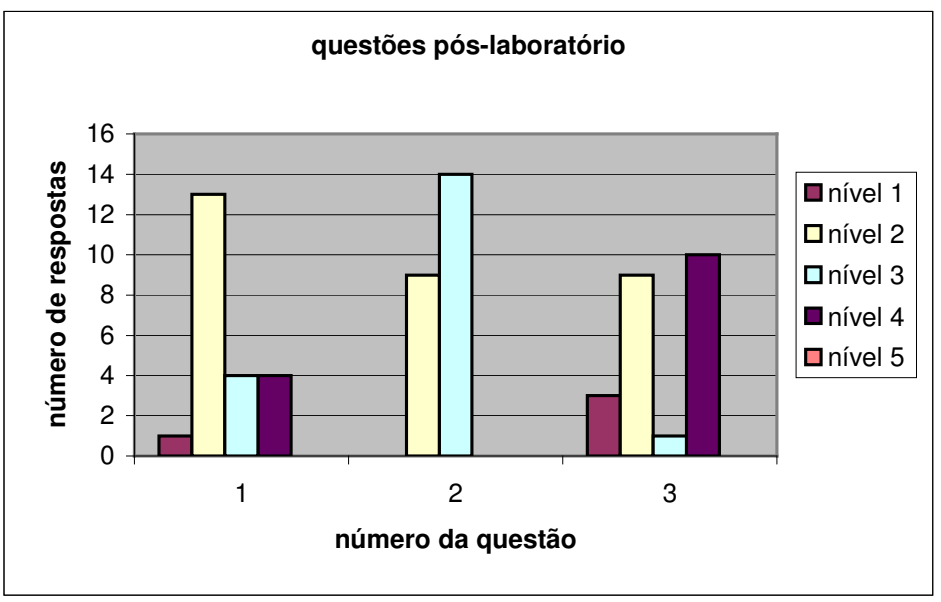

Figura 7. Nível de cognição das respostas dos alunos na aula pós-laboratório da Primeira Série II

Um elevado número de respostas de nível $\mathrm{N} 1$ ainda persiste no fechamento do assunto na primeira série I. Verificou-se que os alunos que apresentaram essas respostas lembram do conceito, pois respondem as questões com argumentos discutidos em sala de aula ou no experimento, mas não conseguem resolver os problemas analisando os processos de controle de variáveis e suas relações causais, o que evidencia a não compreensão dos significados conceituais necessários para sua resolução. $O$ aluno lembra o que é densidade, principalmente devido à realização do experimento, mas quando é questionado a explicar se a temperatura influencia a densidade de um material, como por exemplo a flutuação do gelo na água, não relaciona o fato de a água no estado líquido e sólido constituir o mesmo material, e algumas vezes responde que o gelo derrete diminuindo sua densidade, o que nos leva a considerar que o aluno não compreendeu o conceito $e$ só relatou dados relembrados. Com relação aos alunos da Série II, prevalecem as respostas classificadas como $\mathrm{N} 2$, nas quais os alunos compreendem o problema, pois em suas repostas é perceptível esse entendimento, porém não identificam todas as variáveis ou não justificam suas respostas.

Nos exemplos apresentados acima fica evidente a diferença de uma resposta classificada no nível $\mathrm{N} 1$ e outra no $\mathrm{N} 2$. Nas respostas $\mathrm{N} 1$, os alunos não compreendem o problema e respondem sem raciocinar sobre o que deve ser buscado. Nas respostas N2, porém, os alunos já conseguem identificar o problema, mas sentem dificuldades em identificar as variáveis e processos de controle para sua solução. 
Constata-se ainda, um grande número de respostas de nível N4 nas duas salas, nível este que exige habilidades cognitivas de alta ordem, como analisar e avaliar as variáveis, propor hipóteses para a solução do problema e analisar as relações causais, condizentes com a questão proposta pela professora, a qual exige estes tipos de raciocínios. Conforme mostram as figuras 6 e 7, as respostas classificadas no nível N4 ocorrem com maior freqüência na questão 3, a qual exigia habilidades cognitivas de alta ordem. A questão 1 também apresentou algumas respostas da alta ordem nas duas classes, podendo-se inferir que questões de menor nível cognitivo podem permitir que os alunos explicitem suas idéias utilizando argumentos e raciocínios de ordem superior, entretanto, o número observado é pequeno, talvez, por se tratarem de questões escritas. Também, pode-se considerar, se essas questões tivessem sido propostas em sala, com a mediação da professora, a manifestação de habilidades cognitivas de alta ordem poderia ter sido maior.

Novamente, a maior diferença nas respostas das duas salas se manifesta no maior número de respostas $\mathrm{N} 1$ da série I, enquanto na série II sobressaem as respostas $\mathrm{N} 2$, talvez pelo fato de a professora ter apresentado, durante as aulas, um número maior de questões que exigissem o entendimento dos conceitos, e assim os alunos tiveram maior oportunidade de compreender o que se buscava.

Com relação às outras respostas, as habilidades cognitivas manifestadas nas duas salas não se diferenciam muito. Os alunos das duas salas conseguiram compreender os problemas propostos, identificar as variáveis e processos de controle e até mesmo superar as exigências do N3 e manifestar respostas que exibiam elaboração de hipóteses e análise de variáveis, ou seja, habilidades cognitivas de alta ordem.

Nenhuma questão foi classificada no nível N5 de habilidades cognitivas, talvez pelo fato de a professora não proporcionar momentos que exigissem tal nível, ou questões que permitissem a elaboração de respostas com habilidades de generalização. Segundo Zoller (2002), o bom resultado dos alunos em questões algorítmicas não implica bom resultado em questões HOCS ou LOCS; e os alunos consideram as questões HOCS as mais difíceis. Em outras palavras, êxito em qualquer uma das categorias não sugere êxito em outra questão de qualquer categoria.

Pode-se considerar também que alcançar as habilidades cognitivas exigidas no nível N3 parece ser mais complexo do que está proposto, ou seja, identificar 
variáveis, estabelecer processos de controle e encontrar uma possível solução para o problema exige grande esforço cognitivo por parte do aluno, o qual, muitas vezes não apresenta conceitos suficientes para alcançar tal exigência, ou, por vezes, não é estimulado ou conduzido pelo professor a pensar de tal modo. Talvez o nível N3 possa ser entendido como uma transição entre os LOCS e HOCS.

\subsubsection{Considerações sobre a atividade experimental investigativa: Densidade}

As aulas ministradas pela professora apresentam as características de uma atividade experimental investigativa, pois ela, por meio de uma situação problema, permitiu que os alunos elaborassem suas hipóteses, investigassem a questão proposta e propusessem soluções.

A análise da seqüência de quatro aulas para a construção do conceito de densidade, discutida neste trabalho, evidencia grande participação dos alunos na elaboração de hipóteses e respostas de alta ordem cognitiva. Por mais que a grande parte das respostas tenha se enquadrado no nível N3, classificado ainda como nível de respostas de baixa ordem cognitiva, há de se considerar que é um fator relevante para o desenvolvimento de habilidades cognitivas de alta ordem, requeridas na aula em que o professor realiza o fechamento do assunto, na utilização pelos alunos de argumentos e raciocínios eficazes para responder às questões que exigem levantamento de hipóteses e avaliação de condições para problemas generalizados.

A presença de um grande número de respostas de baixa ordem cognitiva pode estar relacionada com o grau de exigência do pesquisador em relação às habilidades cognitivas, conforme argumenta Zoller (1993), uma vez que o mesmo nível N3 considerado nesta pesquisa como baixa ordem cognitiva poderia ser considerado por outro pesquisador, em outra situação, como alta ordem cognitiva. Verifica-se que os níveis cognitivos das respostas elaboradas pelos alunos estão relacionados com os níveis cognitivos das questões propostas pelo professor. Ou seja, quando o professor questiona os alunos para recordar algo (questões de nível P1), as respostas dos alunos são condizentes com o nível exigido, geralmente de nível N1 ou N2 de cognição. Porém quando o professor exige capacidade de avaliação ou elaboração de respostas, os alunos apresentam raciocínios de alta 
ordem cognitiva, como controle de variáveis e suas relações causais (Yarden et al., 2001).

Contudo, pode-se considerar que o conjunto de atividades experimentais desenvolvidas para a construção do conceito de densidade alcançou, em sua maioria, respostas e questões de nível N3. Estes resultados contribuem para o processo de elaboração de respostas de nível N4 no fechamento do assunto.

$\mathrm{Na}$ descrição das falas, os alunos aparecem constantemente como agentes ativos na aula. Com o auxílio do professor, propondo questões elicitativas, os alunos participaram do processo de elaboração de hipóteses e explicações para o problema, encarando o trabalho de demonstração e experimentação como investigação, não ficando a ação do aluno limitada à observação (CARVALHO et al., 1999).

As aulas ministradas pela professora da escola A permitiram a participação de toda a classe. Porém, verifica-se que alguns alunos se abstêm dos diálogos e algumas vezes fazem comentários não relacionados com as aulas. É evidente também a participação mais freqüente de alguns alunos do que outros, como por exemplo os alunos A1 e A5, indicados nas transcrições apresentadas neste trabalho. Em outros trechos que não foram incluídos nesta redação, a participação dos alunos A4, A6, A7 também é mais constante.

Segundo Carvalho et al. (1999), pode-se atribuir estes resultados à conduta da professora, uma vez que em atividades investigativas a função do professor se torna um exercício difícil pelo fato de não poder dar a resposta pronta, pelo contrário, é preciso conduzir o aluno à conclusão. Essa atitude pode gerar certa impaciência nos alunos, uma vez que não estão acostumados a pensar, esperando que a professora responda ao problema. Assim, o professor precisa estar atento para que sua atitude não impeça as perguntas dos alunos. Talvez o fato de a professora sempre perguntar aos alunos e poucas vezes responder, possa contribuir para a pouca participação de alguns alunos; ou ainda, por eles se sentirem intimidados em expor suas idéias frente aos colegas. A presença da câmera e de uma pessoa externa ao contexto da sala também podem ter contribuído para esse fato.

Tratando-se da primeira série, os resultados obtidos são razoáveis, uma vez que os alunos podem não estar acostumados ou preparados para expor suas idéias em público e a timidez e receio em serem repreendidos pelos colegas ou professor os impeçam de participar mais ativamente. 
Em geral, os alunos aplicaram corretamente o conceito em situações problemas e participaram na análise e elaboração de hipóteses para as situações não familiares propostas pela professora.

\subsection{Escola A}

\subsubsection{Experimento: Temperatura de Ebulição}

Esta atividade apresenta algumas diferenças se comparada ao experimento de densidade. O desenvolvimento do conceito de densidade teve início com demonstrações experimentais investigativas, realizadas pela professora, e posteriormente os alunos foram ao laboratório investigar os materiais com o auxílio do conceito construído na seqüência de atividades investigativas.

A atividade sobre a temperatura de ebulição pode ser denominada laboratório aberto (CARVALHO et al., 1999). Os autores utilizam o termo Laboratório Aberto para definir uma atividade experimental investigativa na qual o aluno se envolve na resolução de um problema, e se mobiliza à procura de uma metodologia para a sua resolução. Esta atividade pode ser dividida em seis momentos: proposta do trabalho, levantamento de hipóteses, elaboração do plano de trabalho, montagem dos arranjos experimentais e coleta de dados, análise dos dados e conclusão.

Desta forma, a atividade experimental desenvolvida pela professora da Escola A com os alunos da Primeira Série I, apresenta as características do Laboratório Aberto, conforme será discutido a seguir.

\section{Primeira aula}

Com esse experimento investigativo, a professora pretendia que os alunos verificassem que a temperatura de ebulição também pode auxiliar na identificação de um material. Para isso, os alunos, por meio do experimento, analisariam primeiramente os fatores que influenciam a temperatura de ebulição de um material, partindo de suas hipóteses propostas nesta aula. Porém, no início da aula, a professora observa que os alunos não conhecem o significado do conceito de temperatura de ebulição: 


\begin{tabular}{|l|l|l|}
\hline \multicolumn{1}{|c|}{ Tempo } & \multicolumn{1}{|c|}{ Discurso } & Análise \\
\hline $02: 45$ & $\begin{array}{l}\text { P: A pergunta agora é...será que o ponto de ebulição pode } \\
\text { auxiliar na identificação de um material? } \\
\text { P:Então minha primeira pergunta para vocês é...que que é } \\
\text { ponto de ebulição? } \\
\text { P:Que que é ebulição...que que significa ebulição para vocês? }\end{array}$ & \\
\hline $03: 15$ & P:O que é ebulição...de novo & N2 \\
\hline $03: 30$ & Al8: Efervescência & P2 \\
\hline $03: 32$ & $\begin{array}{l}\text { P:Efervescência é a mesma coisa que ebulição? } \\
\text { P:Al4 responde pra mim o que que é efervescência? }\end{array}$ & N2 \\
\hline $03: 40$ & $\begin{array}{l}\text { Al4: Bolhinhas } \\
\text { P:Quando se desprende gás de um material...se forma um gás }\end{array}$ & $\begin{array}{l}\text { P:Então Al8 quando a gente fala em efervescência } \\
\text { normalmente a gente se refere ao desprendimento de gás } \\
\text { quando se forma um gás...na interação do sal de fruta com } \\
\text { água forma um gás...tá...então a gente chama isso de } \\
\text { efervescência...então não é exatamente a mesma coisa } \\
\text { (explicação da professora)) }\end{array}$ \\
\hline
\end{tabular}

Em seguida, a professora verifica que os alunos apresentam dificuldades em diferenciar o significado de temperatura de ebulição e evaporação:

\begin{tabular}{|c|c|c|}
\hline Tempo & Discurso & Análise \\
\hline 05:25 & $\begin{array}{l}\text { P:Então oh...ebulição gente...eu vou definir para vocês...é a } \\
\text { passagem forçada por uma fonte de calor externa do estado } \\
\text { líquido para o estado gasoso...então oh ((escreve no quadro)) } \\
\text { ((ebulição: passagem do estado líquido para o gasoso que } \\
\text { ocorre com o auxílio de uma fonte externa além da } \\
\text { temperatura ambiente)) }\end{array}$ & \\
\hline 06:38 & $\begin{array}{l}\text { P: Oh presta atenção...vamos voltar...a ebulição é o que a } \\
\text { gente chama de ferver...quando a água tá fervendo ela tá em } \\
\text { ebulição...quando um material tá fervendo ele tá em ebulição }\end{array}$ & \\
\hline 06:56 & $\begin{array}{l}\text { P:Qual a diferença ... evaporação vocês sabem o que é..o que } \\
\text { é evaporação? }\end{array}$ & $\mathrm{P} 1$ \\
\hline 07:03 & Al13: A água passa do líquido pro gasoso & N2 \\
\hline 07:07 & Al14: Ciclo natural da água & N1 \\
\hline 07:11 & $\begin{array}{l}\text { P:A água passa do líquido para o gasoso...mas..só que em } \\
\text { que condições? }\end{array}$ & P1 \\
\hline 07:14 & Al7: Calor (a) & \\
\hline 07:17 & $\begin{array}{l}\text { P:Fala Al7 qual tipo calor? } \\
\text { P:Calor ...da onde vem o calor? }\end{array}$ & \\
\hline 07:21 & Al7: Solar (b) & N3 $(a, b)$ \\
\hline 07:24 & P:Solar ou do ambiente né...então se a gente pensar & P1 \\
\hline 07:47 & P: Al15 como é que eu defino evaporação? & \\
\hline 07:52 & Al15: Passagem do líquido para o gasoso & N2 \\
\hline 07:56 & $\begin{array}{l}\text { P:Tá do líquido pro gasoso tudo bem mas qual a diferença de } \\
\text { quando a água tá evaporando e quando a água tá fervendo? } \\
\text { P:Qual a diferença de um processo pro outro? }\end{array}$ & P2 \\
\hline 08:16 & $\begin{array}{l}\text { Al15: Quando esquenta a água ela ebuli quando evapora a } \\
\text { água seca (c) }\end{array}$ & \\
\hline 08:19 & P:Em qual que você está esquentando? & $\mathrm{P} 1$ \\
\hline 08:21 & Al15: Quando ferve (d) & \\
\hline 08:27 & $\begin{array}{l}\text { P:Quando você ferve } \\
\text { P:A evaporação você usa... a água usa o calor de onde para } \\
\text { evaporar? }\end{array}$ & P1 \\
\hline 08:30 & Al1: Do ambiente & N3 $(c, d, e)$ \\
\hline
\end{tabular}




\begin{tabular}{|l|l|l|}
\hline $08: 33$ & P:Do ambiente então oh ((vai ao quadro)) & P1 \\
\hline $09: 15$ & P:Gente deixa eu perguntar para vocês ...outra coisa & \\
\hline $09: 22$ & $\begin{array}{l}\text { P:Quando eu falo..ai também eu vou contar para vocês... } \\
\text { ponto de ebulição vocês sabem o que pode ser isso... ponto de } \\
\text { ebulição? }\end{array}$ & $\begin{array}{l}\text { Al11: Eu acho que é o ponto de temperatura que chega } \\
\text { assim... a água para evaporar }\end{array}$ \\
\hline $09: 31$ & $\begin{array}{l}\text { P:Pra evaporar? } \\
\text { P:Oh a Al11 falou uma coisa interessante...quando eu falo } \\
\text { ponto de ebulição eu tô me referindo a uma... temperatura } \\
\text { P:Então essa palavra ponto no caso eu tô me referindo à } \\
\text { temperatura de ebulição } \\
\text { P:Então Al11 não é a temperatura que um material evapora... } \\
\text { eu tô me referindo à ebulição...é a temperatura que um } \\
\text { material entra em ebulição...popularmente eu vou dizer é a } \\
\text { temperatura que um material ferve }\end{array}$ \\
\hline
\end{tabular}

Observa-se, neste episódio, que os alunos ainda apresentam dificuldades em diferenciar temperatura de ebulição e evaporação. É interessante verificar que a mediação da professora é de suma importância, pois as respostas dos alunos são geralmente monossilábicas, não exibindo um raciocínio lógico, mas a professora procura direcionar o raciocínio dos alunos, a fim de que estes manifestem respostas mais completas.

Nesta etapa da aula, a professora precisa fazer algumas definições teóricas como temperatura de ebulição e evaporação para que a aula prossiga e a atividade experimental seja realizada.

Após essas definições, uma aluna expressa uma idéia prévia, a qual será utilizada como uma das hipóteses para a investigação experimental. Novamente, a mediação da professora expressa sua relevância, pois aproveita a fala da aluna para iniciar a elaboração de hipóteses para a investigação do problema experimental:

\begin{tabular}{|l|l|l|}
\hline \multicolumn{1}{|c|}{ Tempo } & \multicolumn{1}{|c|}{ Discurso } & \multicolumn{1}{c|}{ Análise } \\
\hline $11: 05$ & $\begin{array}{l}\text { P:Como é que a roupa seca no varal? } \\
\text { P:Fala Al4 }\end{array}$ & P3 \\
\hline $11: 08$ & Al4: Dependendo da quantidade de água ela vai evaporar & N4 \\
\hline $11: 13$ & $\begin{array}{l}\text { P:Dependendo da quantidade ...pera ai oh...oh o que a Al4 tá } \\
\text { falando...dependendo da quantidade de... }\end{array}$ & \\
\hline $11: 21$ & Al4: De água ai ela pode evaporar... & \\
\hline $11: 27$ & $\begin{array}{l}\text { P:Então oh a minha pergunta é...tem uma coisa interessante } \\
\text { que você falou aí que a gente vai pensar sobre isso } \\
\text { P:Dependendo da quantidade...eu não se se você falou } \\
\text { exatamente isso Al4...vou fazer uma pergunta }\end{array}$ & \\
\hline $11: 49$ & $\begin{array}{l}\text { P:Vocês acham que a quantidade de água afeta a temperatura } \\
\text { que ela evapora ou a temperatura que ela ferve? } \\
\text { P: Que temperatura que a água ferve? }\end{array}$ & P3 \\
\hline $11: 57$ & Al: Cem graus & $\mathrm{N} 2$ \\
\hline $12: 01$ & P:Em qualquer lugar é cem graus? & P2 \\
\hline $12: 05$ & Al1 não ((murmúrios)) & $\mathrm{N} 1$ \\
\hline $12: 11$ & P:Então oh vocês estão me dizendo que a água ferve a cem & P3 \\
\hline
\end{tabular}




\begin{tabular}{|l|l|l|}
\hline & $\begin{array}{l}\text { graus sempre ela ferve a cem graus? } \\
\text { P:Depende do quê? }\end{array}$ & \\
\hline $12: 16$ & Al1: Depende do lugar (f) & \\
\hline $12: 18$ & P:Por que depende do lugar? & \\
\hline $12: 23$ & $\begin{array}{l}\text { Al1: Porque tem lugar que é mais quente por exemplo aqui } \\
\text { perto do sul do Brasil é menos quente que lá ((faz gestos com } \\
\text { as mãos)) (g) } \\
\text { Al1: Aqui pode ferver mais rápido que lá (h) }\end{array}$ & \\
\hline
\end{tabular}

Partindo de uma questão para a qual a professora exige que os alunos utilizem as informações e dados discutidos até o momento para fazer inferências (P3), a aluna propõe uma hipótese para solução do problema (N4).

Ao questionar os alunos sobre os fatores que interferem na temperatura de ebulição da água, um aluno propõe uma outra hipótese com a concepção de que o tempo influencia a temperatura. É importante relatar que quando o aluno se refere à temperatura do local, poderíamos utilizar em linguagem formal ou científica, o termo temperatura ambiente.

Ao perceber que os alunos ainda estão tendo dificuldades em compreender o significado de evaporação e temperatura de ebulição, a professora continua a discussão:

\begin{tabular}{|c|c|c|}
\hline Tempo & Discurso & Análise \\
\hline $12: 39$ & $\begin{array}{l}\text { P:Então evaporação é uma coisa ebulição é outra....a gente vai } \\
\text { ter que rediscutir...vocês estão confundindo } \\
\text { P:Vamos só voltar para evaporação depois a gente vai para } \\
\text { ebulição...quando eu tenho roupa no varal e a roupa está } \\
\text { secando que que tá acontecendo com a água? }\end{array}$ & $\mathrm{P} 2$ \\
\hline $12: 53$ & Al1: Evaporando & N2 \\
\hline $12: 56$ & $\begin{array}{l}\text { P:Evaporando } \\
\text { P:Que que acontece então...se a gente tá num dia vai vinte e } \\
\text { cinco vinte e dois graus a roupa seca no varal? }\end{array}$ & $\mathrm{P} 2$ \\
\hline 13:06 & Al: Seca & N2 \\
\hline 13:08 & Al1: Vai demorar um pouco mais & N3 \\
\hline 13:08 & Al:Sim & \\
\hline 13:09 & P:Mas a água evapora? & $\mathrm{P} 2$ \\
\hline $13: 10$ & Al: Evapora & N2 \\
\hline $13: 12$ & $\begin{array}{l}\mathrm{P}: \text { E se a gente tá num dia mais frio a dez doze graus assim a } \\
\text { roupa seca? }\end{array}$ & $\mathrm{P} 2$ \\
\hline 13:17 & Al1: Vai secar & N2 \\
\hline 13:22 & $\begin{array}{l}\text { P:Vai secar } \\
\text { P:Então gente...a evaporação ela pode acontecer a qualquer } \\
\text { temperatura onde a água esteja liquida } \\
\text { P:Se você tem água liquida você tem evaporação a qualquer } \\
\text { temperatura }\end{array}$ & \\
\hline
\end{tabular}

Por se tratar de questões que não exigem análise ou processos de controle (P2), a maioria das respostas dos alunos nos primeiros minutos da aula foi classificada como N2. 
A professora vai anotando no quadro as hipóteses dos alunos sobre os fatores que alteram a temperatura de ebulição, mas é notória a relação que os alunos fazem do tempo com a temperatura:

\begin{tabular}{|c|c|c|}
\hline Tempo & Discurso & Análise \\
\hline $14: 50$ & $\begin{array}{l}\text { P:Oh então olha aqui...a ebulição vocês estão me dizendo que } \\
\text { ela ocorre a uma determinada temperatura } \\
\text { P:É...que que afeta essa temperatura de ebulição? }\end{array}$ & P3 \\
\hline 14:57 & $\begin{array}{l}\text { P:O Al1 tem uma hipótese...um lugar mais quente que que } \\
\text { acontece com a temperatura de ebulição num lugar mais } \\
\text { quente? }\end{array}$ & P3 \\
\hline $15: 02$ & Al1: Vai ficar mais rápida (i) & \\
\hline 15:03 & P:Vai ficar mais rápida...oh & \\
\hline 15:06 & Al1: Vai ser mais fácil de acontecer (j) & \\
\hline $15: 10$ & $\begin{array}{l}\text { P:Vai ser mais fácil de acontecer } \\
\text { P:Que que vai acontecer com a temperatura de ebulição de } \\
\text { uma material que tá fervendo? }\end{array}$ & \\
\hline 15:14 & Al1: Vai ser mais alta (I) & $\mathrm{N} 4(\mathrm{i}, \mathrm{j} . \mathrm{I})$ \\
\hline $15: 20$ & P:Vai ser mais alta & \\
\hline 16:07 & $\begin{array}{l}\text { P:Então Al1 tô colocando aqui ((no quadro)) que a temperatura } \\
\text { do ambiente vai afetar a temperatura de ebulição de um } \\
\text { material } \\
\text { P:Isso gente presta atenção...são coisas que nos vamos } \\
\text { discutir...então esse é o primeiro ponto que a gente vai discutir }\end{array}$ & \\
\hline 16:22 & Al7: A pressão (m) & \\
\hline $16: 23$ & P:A pressão Al7...por quê? & \\
\hline 16:25 & $\begin{array}{l}\text { Al7: Porque assim... um dia que eu tava esquentando água pra } \\
\text { minha mãe e ela falou para mim põe a tampa na panela para } \\
\text { cozinhar mais rápido ( } n \text { ) }\end{array}$ & N3 $(m, n)$ \\
\hline 16:37 & P:O que acontece quando você coloca a tampa na panela? & P3 \\
\hline $16: 40$ & Al7: Ah em contato com a pressão...não sei... & \\
\hline 16:55 & $\begin{array}{l}\text { P:Então você acha que a pressão...é a gente vai rediscutir isso } \\
\text { P: Que mais...a quantidade...a Al4 falou da quantidade a Al8 } \\
\text { colocou outra idéia }\end{array}$ & \\
\hline 17:05 & $\begin{array}{l}\text { P:A quantidade....cem gramas de água trezentos gramas de } \\
\text { água...a temperatura de ebulição é a mesma.. que vocês } \\
\text { acham? } \\
\text { P:É ou não? } \\
\text { P:Que você acha Al16? }\end{array}$ & P3 \\
\hline 17:15 & Al16: Acho que não por que muda a quantidade & N3 \\
\hline 17:17 & P:Muda a quantidade & \\
\hline $17: 20$ & $\begin{array}{l}\text { Al1: Acho que é equivalente né...porque conforme você } \\
\text { aumenta você aumenta o tempo também } \\
\text { Al1:Do mesmo jeito que você...se você vai aumentar a massa } \\
\text { você vai aumentar o volume aumentando o volume aumenta o } \\
\text { tempo que vai demorar }\end{array}$ & N4 \\
\hline 17:34 & $\begin{array}{l}\text { P:Vamos ver mas é uma hipótese...quantidade } \\
\text { P:Que mais que pode afetar...que por hipótese pode afetar a } \\
\text { temperatura que um material ferve...vamos ver mas é uma } \\
\text { hipótese...quantidade } \\
\text { P:Que mais que pode afetar...que por hipótese pode afetar a } \\
\text { temperatura que um material ferve? }\end{array}$ & \\
\hline
\end{tabular}


Continuando a elaboração de hipóteses para investigação, a professora propõe uma situação:

\begin{tabular}{|l|l|l|}
\hline \multicolumn{1}{|c|}{ Tempo } & \multicolumn{1}{|c|}{ Discurso } & \multicolumn{1}{c|}{ Análise } \\
\hline $20: 03$ & $\begin{array}{l}\text { P:Vocês acham que o tipo do material afeta a temperatura de } \\
\text { ebulição? }\end{array}$ & P3 \\
\hline $20: 06$ & $\begin{array}{l}\text { Al: Sim } \\
\text { Al1: Sim }\end{array}$ & \\
\hline $20: 25$ & $\begin{array}{l}\text { P:Então oh...quando eu tenho um material diferente do outro } \\
\text { vocês acham que a temperatura de ebulição muda? }\end{array}$ & P3 \\
\hline $20: 34$ & Al1:Muda & \\
\hline $20: 37$ & P:Por quê? & $\begin{array}{l}\text { Al1: Porque é diferente água de óleo...óleo de álcool...álcool } 3 \\
\text { de mel...mel de... }\end{array}$ \\
\hline $20: 40$ & $\begin{array}{l}\text { P:Então oh...o Al1 tá falando assim... que a temperatura de de } \\
\ldots \text { que o álcool ferve é diferente da temperatura que a água } \\
\text { ferve...a temperatura diferente que o óleo ferve assim por } \\
\text { diante }\end{array}$ \\
\hline $20: 45$
\end{tabular}

No tempo 20:40, o Al1 parece responder à questão da professora recordando o experimento da densidade, no qual eles observaram que os materiais apresentavam densidades diferentes e, portanto, poderiam ser diferenciados com 0 auxílio desta constante, assim o aluno relaciona o antigo conceito ao novo problema identificando as variáveis para a sua solução.

Em seguida, a professora propõe outra situação para a proposição de hipóteses que possivelmente os alunos não emitiriam por si próprios:

\begin{tabular}{|l|l|l|}
\hline Tempo & \multicolumn{1}{|c|}{ Discurso } & Análise \\
\hline $22: 30$ & $\begin{array}{l}\text { P:Vocês acham por exemplo...que a fonte de calor que eu } \\
\text { tenho lá vai afetar a temperatura que um material ferve? }\end{array}$ & P3 \\
\hline $22: 42$ & $\begin{array}{l}\text { P:Por exemplo se eu colocar o material para ferver no fogão } \\
\text { ou na lamparina no bico de gás ou na lamparina vai alterar a } \\
\text { temperatura de ebulição? } \\
\text { P:Vai alterar a temperatura de ebulição sim ou não? }\end{array}$ & \\
\hline $22: 46$ & Al: Vai & \\
\hline $22: 49$ & $\begin{array}{l}\text { Al7: A temperatura de ebulição não muda o que vai mudar é o } \\
\text { tempo que a ebulição acontece }\end{array}$ & N4 \\
\hline $22: 55$ & $\begin{array}{l}\text { P: O Al7 tá falando uma coisa...todo mundo acha isso? } \\
\text { Repete... }\end{array}$ & \\
\hline $23: 02$ & $\begin{array}{l}\text { Al7: A temperatura de ebulição não muda o que vai mudar é o } \\
\text { tempo que a ebulição acontece }\end{array}$ & \\
\hline $23: 12$ & $\begin{array}{l}\text { P: O Al7 tá falando que não muda a temperatura muda o } \\
\text { tempo... que que vocês acham? }\end{array}$ & P3 \\
\hline $23: 20$ & $\begin{array}{l}\text { Al6: Eu acho que sim professora porque se você coloca no no } \\
\text { fogo alto vai ferver rápido agora se você colocar no fogo baixo } \\
\text { demora mais. }\end{array}$ & N4 \\
\hline $23: 30$ & $\begin{array}{l}\text { P:Vai demorar mais...mas será que a água fica igualmente } \\
\text { quente? } \\
\text { P:A temperatura da água fica igual? }\end{array}$ & P3 \\
\hline $23: 55$ & $\begin{array}{l}\text { Al: Não } \\
\text { P:Alguns de você têm algumas hipóteses sobre o que que }\end{array}$ & \\
\hline
\end{tabular}


Os alunos neste episódio, utilizam as idéias cotidianas para responder à hipótese proposta pela professora, ou seja, que em fogo alto a temperatura é a mesma mas o tempo é alterado. Não é possível interpretar se os alunos analisaram as variáveis do problema, porém eles elaboram suas hipóteses e sugerem respostas para o problema, exibindo habilidades cognitivas de alta ordem.

Nestes episódios, os alunos, com o auxílio da professora, levantam suas hipóteses para responder à questão problema: Quais fatores afetam a temperatura de ebulição de um material? As hipóteses apresentam concepções alternativas como, por exemplo, aumentando a quantidade de um material conseqüentemente a temperatura aumenta e o tempo também. É interessante observar que os alunos se referem ao tempo durante a aula; mas o que a professora pretende com 0 experimento é exatamente tentar construir um conceito sólido e superar tais idéias alternativas.

Analisando as falas de todos os alunos e da professora na primeira aula, verifica-se que no início da aula a professora pretende conceituar evaporação e ebulição antes de propor o problema principal. Assim, no início da aula a grande maioria das questões propostas pela professora foi classifica no nível P1 ou P2, pois estas questões exigiam somente recordar ou comparar dados, como por exemplo: " $A$ que temperatura a água ferve?" ou "A que temperatura a água evapora?" As respostas dos alunos a essas questões foram classificadas nos níveis N1 ou N2, ou seja, respostas de baixa cognição, uma vez que exigiam dos alunos expor um dado relembrado, aplicar conceitos, mas não exigiam processo de identificação de variáveis ou justificativas. Nenhuma resposta foi classificada como N4 neste momento da aula.

Entretanto, a questão problema proposta pela professora : "O que afeta a temperatura de ebulição de um material?" requer que os alunos proponham hipóteses para a sua solução. Assim, após expor a pergunta, muitas hipóteses foram sugeridas pelos alunos e algumas delas foram escolhidas para investigação. Verifica-se que a professora elaborou um maior número de questões que podem ser classificadas no nível P3 e que as respostas dos alunos estão entre os níveis HOCS e LOCS (N3 e N4). A tabela 4.7 mostra a porcentagem de questões propostas pela professora e de respostas dos alunos: 
Tabela 4.7- Porcentagem de questões propostas e respostas dos alunos

\begin{tabular}{|c|c|c|c|}
\hline \multicolumn{2}{|c|}{$\begin{array}{l}\text { Questões propostas pela professora } \\
\qquad(\mathrm{N}=39)\end{array}$} & \multicolumn{2}{|c|}{ Respostas dos alunos ( $\mathrm{N}=36)$} \\
\hline Nível & $\%$ & Nível & $\%$ \\
\hline $\mathrm{P} 1$ & 26 & N1 & 8,3 \\
\hline $\mathrm{P} 2$ & 31 & N2 & 55,6 \\
\hline P3 & 43 & N3 & 11,1 \\
\hline \multirow{2}{*}{\multicolumn{2}{|c|}{$\mathrm{N}=$ número total }} & N4 & 25 \\
\hline & & N5 & 0 \\
\hline
\end{tabular}

Esta etapa da aula teve duração de vinte e sete minutos, o restante foi destinado para os alunos elaborarem os procedimentos.

A professora, então, escreveu no quadro as hipóteses propostas pelos alunos e explicou que deveriam, em grupo, investigar uma delas. As hipóteses propostas para a questão: “O que afeta a temperatura de ebulição de um material?", foram:

- temperatura ambiente (temperatura inicial do material);

- pressão;

- quantidade de material;

- intensidade da chama;

- tipo ou natureza do material, sendo que as duas últimas foram propostas pela professora

Os alunos formaram 5 grupos com cinco ou seis componentes em cada, com o objetivo de elaborar o plano de trabalho para uma das cinco varáveis, que deveria conter o material necessário para a sua realização, as previsões e o procedimento detalhado (Anexo E).

Esse plano de trabalho prévio deveria ser entregue à professora para que ela pudesse corrigi-lo e verificar as possibilidades de sua execução ou não. Após as correções necessárias, a professora devolveu os procedimentos para os alunos para que, durante a realização da atividade experimental, descrevessem os dados e as conclusões obtidas. Após a discussão em sala ocorrida na última aula, os alunos elaboraram um relatório individual (Anexo F).

Foram transcritas e analisadas as falas de dois grupos durante a elaboração do procedimento prévio na primeira aula e também durante a execução do experimento, na segunda aula. Foram analisados os planos prévios de três grupos, pois os outros dois entregaram somente o relatório final individual. As anotações realizadas, como por exemplo, coleta de dados e resultados também foram coletadas e analisadas. Algumas anotações, como elaboração da conclusão, desses três grupos também foram analisadas, tanto quanto os relatórios finais individuais 
dos alunos integrantes desses grupos. A escolha desses três grupos se deve ao fato de conter informações mais completas desde a elaboração do plano de trabalho prévio, execução e conclusões e, também, para manter homogeneidade na análise, a fim de verificar possíveis mudanças em seus entendimentos prévios. Entretanto, exemplos de respostas de outros grupos podem ser utilizados para fundamentar a análise de dados. É importante relatar que alguns dos relatórios finais apresentados individualmente pelos alunos componentes de um mesmo grupo eram muito semelhantes, evidenciando que alguns alunos copiaram dos outros. Assim, as anotações realizadas pelos alunos após a realização do experimento apresentam resultados mais significativos para a pesquisa do que os relatórios individuais.

\section{A elaboração do procedimento experimental}

Os três grupos analisados serão denominados conforme a variável investigada: temperatura inicial do material; pressão e fonte de calor.

Alguns dos planos prévios elaborados por esses grupos estão apresentados a seguir. As escritas dos alunos foram fielmente digitadas para facilitar a visualização e a disposição das informações. Estão descritas as previsões, os materiais e os procedimentos propostos por alguns grupos :

- Materiais:

\begin{tabular}{|c|l|}
\hline Grupo & \multicolumn{1}{|c}{ Descrição } \\
\hline Pressão & Panelas (sem tampa, de pressão), termômetro, relógio com cronômetro, água \\
\hline $\begin{array}{c}\text { Fonte } \\
\text { de calor }\end{array}$ & $\begin{array}{l}\text { Lamparina, maçarico, panelas, água, medidor de temperatura, bastão de vidro, } \\
\text { tripé, tela de amianto }\end{array}$
\end{tabular}

É interessante notar que algumas vezes os alunos não apresentam o vocabulário correto para as vidrarias de laboratório, talvez pelo pouco contato com estes, uma vez que se trata da primeira série do ensino médio. Algumas vidrarias são citadas pelo nome correto, pois os alunos perguntavam à professora ou ao laboratorista; ou ainda, algumas delas são descritas mas podem não ter utilidade para a execução do experimento. 


\section{- Procedimento}

\begin{tabular}{|c|l|}
\hline Grupo & \multicolumn{1}{c|}{ Descrição } \\
\hline $\begin{array}{c}\text { T. inicial } \\
\text { do } \\
\text { material }\end{array}$ & $\begin{array}{l}\text { Colocamos água gelada em uma das panelas e água normal em outra, levamos } \\
\text { ao fogo as duas panelas com água, e cronometramos o tempo que as duas } \\
\text { levam para ferver. E mediremos a temperatura tanto antes quanto depois (da } \\
\text { ebulição) com o termômetro. }\end{array}$ \\
\hline $\begin{array}{c}\text { Fonte } \\
\text { de calor }\end{array}$ & $\begin{array}{l}\text { Coloque duas panelas com a mesma quantidade de água e meça a temperatura } \\
\text { das duas panelas de água e faça as comparações }\end{array}$ \\
\hline
\end{tabular}

Os alunos do grupo da fonte de calor se referem à constante volume, somente não colocam a quantidade, mas se atentam a essa questão, manifestando habilidades cognitivas para o controle de variáveis. Os alunos também não se referem à medida de tempo.

Os alunos do grupo da temperatura inicial do material não atentam ao fato de que as quantidades, ou seja, os volumes de água "ambiente" e gelada, precisam ser iguais para que haja somente uma variável a ser investigada. A professora faz essa correção no plano de trabalho para que os alunos não encontrem essa dificuldade na execução do experimento e, principalmente, na análise de dados.

É interessante observar, também, que os alunos desse mesmo grupo primeiramente se referem ao tempo que será cronometrado e somente depois se referem à temperatura, talvez por dificuldades em compreender que o tempo não é o que se deseja determinar, e sim a temperatura. Chama a atenção que, no entanto, os alunos propõem medir a temperatura inicial e final do material, o que revela uma certa habilidade cognitiva referente ao controle de variáveis.

É importante salientar que no final da primeira aula, antes de os alunos se agruparem para elaborar o procedimento, houve uma breve discussão em sala de aula sobre a importância do controle de variáveis, e um dos alunos do grupo que investigou a temperatura inicial do material manifestou essa idéia, conforme mostra o episódio abaixo:

\begin{tabular}{|c|c|c|}
\hline Tempo & Discurso & Análise \\
\hline $25: 29$ & $\begin{array}{l}\text { P: Então por exemplo... para investigar um material } \\
\text { P: Como é que eu faria Al um experimento para verificar se a temperatura afeta } \\
\text { ou não a ebulição de um material como eu faria? } \\
\text { P: Que que eu vou variar? }\end{array}$ & P3 \\
\hline $25: 38$ & Al1: Tempo (f) & \\
\hline $25: 48$ & P: E o que eu que tem que ser igual? & P3 \\
\hline $25: 54$ & Al1: Fonte de calor $(\mathrm{g})$ & \\
\hline $25: 57$ & P:A fonte de calor ...que mais? & \\
\hline $26: 01$ & $\begin{array}{l}\text { Al1: Se você muda uma coisa tem que deixar o resto igual para poder olhar só } \\
\text { aquilo que mudou }(\mathrm{h})\end{array}$ & $\mathrm{N} 4(\mathrm{f}, \mathrm{g}, \mathrm{h})$ \\
\hline
\end{tabular}


26:06 P: Gente isso que o Al1 falou é o mais importante para mim... o que eu quero que vocês percebam....se for estudar o material todo o resto tem que estar igual

$\mathrm{P}$ : Se eu for estudar a pressão o resto tem que tá igual

$\mathrm{P}:$ Se eu for estudar a quantidade de material o resto tem que tá igual

Mas, observa-se nessa discussão que ao responder a pergunta da professora "que eu vou variar?" o Al1 responde "tempo" (25:38) e a professora não se atenta à fala do aluno. Talvez, se uma discussão mais aprofundada sobre a influência do tempo na temperatura de ebulição tivesse ocorrido nessa primeira aula, muitas dificuldades apresentadas pelos alunos poderiam ter sido evitadas.

Em nenhum momento da aula a professora sugere aos alunos a utilização de um cronômetro para a execução da atividade, mas pode-se inferir que, conforme mostram os episódios da aula, diversas vezes os alunos citam o tempo como uma variável, fazendo com que a grande maioria dos grupos sugerisse a utilização de um cronômetro em seus procedimentos experimentais. Talvez, se a professora tivesse questionado e guiado as idéias dos alunos para que determinassem as temperaturas iniciais e a temperatura de ebulição do líquido, acompanhando a variação por certo tempo, essa dificuldade poderia ter sido evitada ou minimizada.

Percebe-se que os alunos apresentam dificuldades em descrever os procedimentos, que são sucintos e com poucas informações. Porém, este fato é compreensível pois os alunos não estão habituados a realizar experimentos deste tipo e, também, evidencia a importância em proporcionar atividades que permitam que os alunos desenvolvam habilidades de escrita, as quais podem contribuir no estímulo de outras habilidades essenciais para o desenvolvimento do raciocínio lógico.

\section{- Previsões}

\begin{tabular}{|c|l|}
\hline Grupo & \multicolumn{1}{|c|}{ Descrição } \\
\hline Pressão & $\begin{array}{l}\text { Esperamos que com a panela fechada a pressão seja maior e a ebulição seja } \\
\text { mais rápida e a temperatura mais alta. }\end{array}$ \\
\hline $\begin{array}{c}\text { Fonte } \\
\text { de calor }\end{array}$ & Que a panela com maçarico esquente mais que a panela com a lamparina \\
\hline
\end{tabular}

Observa-se grande dificuldade por parte dos alunos para propor o objetivo e fazer previsões, o que pode ser explicado, talvez, pelo baixo nível de liberdade dado geralmente aos alunos em atividades laboratoriais, uma vez que, de maneira geral, 
no ensino são priorizadas atividades do tipo "receita". Também, deve se considerar que são alunos da $1^{\text {a }}$ série do ensino médio e, por isso, possuem conhecimentos apenas incipientes de Química. Observa-se, ainda, que alguns planos prévios omitem o objetivo e as previsões, talvez pelos alunos sentirem medo em responder algo diferente do que o professor esperava e serem advertidos. Porém, o engajamento dos alunos na atividade é grande e sua resolução se demonstra desafiadora.

Fica evidente, pela análise dos planos prévios e das transcrições, a dificuldade dos alunos em compreender a relação entre tempo e temperatura. Alguns grupos, ao propor seus procedimentos, determinam o tempo como o objeto de estudo e não a temperatura. Para eles, o tempo é determinante e pode alterar a temperatura.

Um dos grupos, por exemplo, investigou se o volume de um material (o grupo utilizou leite) tem influência na temperatura de ebulição, e o episódio abaixo evidencia a dificuldade descrita:

Al 4: Em quanto tempo qual a temperatura ele atinge?

Al 5: Mas a gente tá olhando o termômetro quando ele começar a ferver a gente olha a temperatura

Al 4: Então... mas se por exemplo eu deixar um minuto o que tem lá dentro vai estar mais quente

P: Perfeito

Al 4: Só que esse também pode atingir a temperatura só que em tempo diferente $P:$ Isso

Um outro grupo, que investigou a temperatura inicial do material, apresenta dificuldades em compreender a hipótese a ser investigada e precisam do auxílio da professora:

Al: Não tem temperatura ambiente tem a temperatura do local

Al 1: Temperatura ambiente professora... nós vamos lá no Paraguai medir o negócio Al: Al 1 você pega água gelada ou água quente

Al: Mas água gelada e água quente não é temperatura ambiente é temperatura do material?

Al1: Não

Al 1: Professora ((foram chamar a professora))

Al: Professora temperatura ambiente é aquilo? 
Al: Vai fazer o quê?

Al 1: Vai fazer temperatura e tempo

((aguardam a professora))

Al 1: Temperatura ambiente já é a temperatura ambiente

$P:$ Na verdade o que muda...vocês não vão conseguir a temperatura certa...o que vocês podem mudar?

$P: A$ temperatura do material

Al 1: Mas aí não é ambiente é material

$P$ : Concorda que não dá...se você tivesse numa sala com ar condicionado tudo bem...mas para se mudar a temperatura do ambiente...

Al 1: Eu queria água em ambientes diferentes professora

$P:$ Mas indiretamente a temperatura afeta a temperatura do material que está presente...então não dá para mudar a temperatura do ambiente...vocês vão variar a temperatura do material em si certo?

$P$ : Vocês escolhem o material. ..pode ser água e vão variar a temperatura do material...indiretamente a temperatura ambiente afeta a temperatura do material

Os alunos não compreendiam a maneira pela qual poderiam alterar a temperatura ambiente da água, a professora, então, sugeriu a mudança na temperatura da água e, com esse auxílio da professora, essa dificuldade é superada.

É importante esclarecer que o grupo que investigou a influência da pressão sobre a temperatura de ebulição do material não executou o procedimento elaborado, uma vez que sugeria a medida da temperatura da água aquecida em panela de pressão. Devido à impossibilidade de se medir a temperatura, a professora sugere um outro procedimento, conforme será discutido adiante.

Nesta mesma aula, após a discussão, os alunos entregaram o plano de investigação para a professora, para que ela pudesse fazer as alterações necessárias e avaliar a possibilidade ou não da realização dos experimentos.

\section{Segunda aula}

Nesta aula, os alunos receberam os procedimentos prévios corrigidos pela professora e foram para o laboratório realizar o experimento. As vidrarias e os materiais de cada grupo já encontravam-se separados na bancada para que os 
alunos não consumissem tempo nessas tarefas. Os alunos realizaram o experimento com muita atenção, porém não foram evidenciadas falas substanciais para serem analisadas na pesquisa. Os alunos executam o experimento e discutem assuntos muitas vezes não referentes a ele. A fase na qual se constata discussão e análise ocorre após a execução experimental, quando os alunos se agrupam e discutem os dados obtidos.

Evidenciam-se poucas dificuldades para a realização do experimento, uma vez que a professora avaliou os procedimentos previamente e orientou os grupos para a execução. Algumas limitações manipulativas são encontradas principalmente na leitura do termômetro, porém, o que fica mais evidente são as dificuldades geradas para analisar os dados e elaborar a conclusão. Outra consideração a fazer é que nem todos os alunos compreendem ou se engajam na atividade de maneira igualitária. Ao mesmo tempo em que alguns alunos compreendem o que estão fazendo e por que estão fazendo, outros permanecem passivos, à espera de repostas, mas, a porcentagem de alunos que se engajaram na atividade, expuseram dúvidas, re-elaboraram suas hipóteses e conclusões após a coleta e análise dos dados, é muito significante.

Após a realização do experimento, a professora pede para que os alunos, em grupos, elaborem suas conclusões e façam um relatório individual contendo: objetivos (com previsões); procedimento detalhado e conclusão.

O episódio abaixo mostra a discussão de um dos grupos investigados (temperatura inicial do material) com a professora para elaborar a pergunta para o relatório, ou seja, o que eles investigaram:

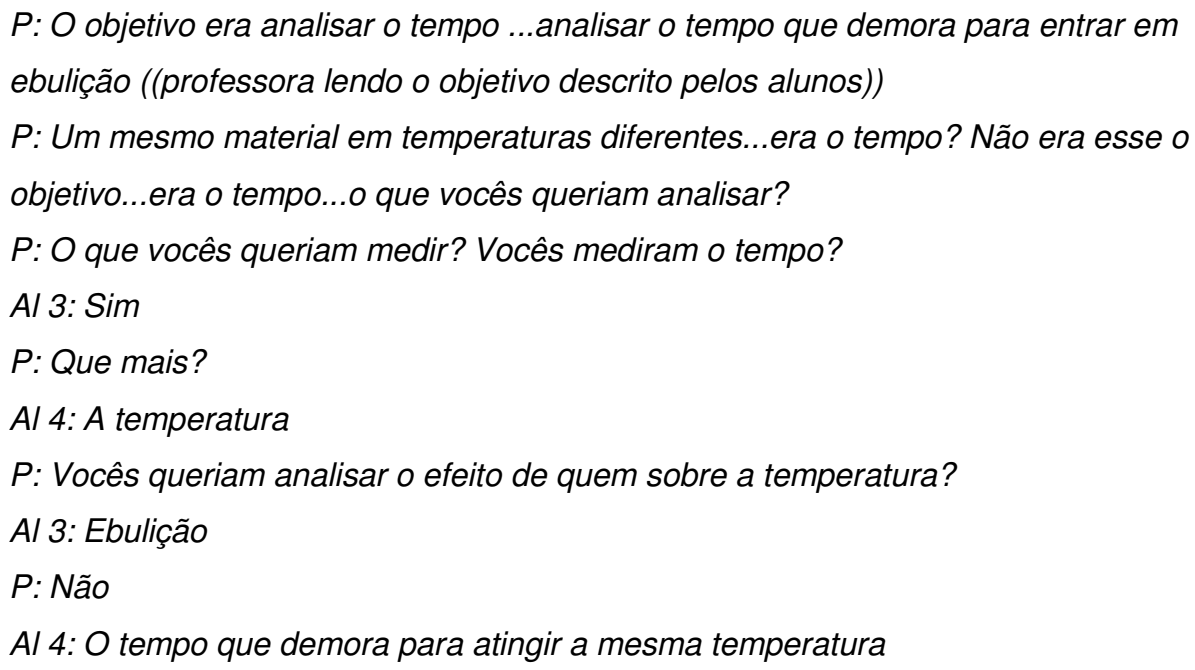


P: Então gente...

P:Vocês estão variando alguma coisa... o quê?

AL1: A chama

P:No caso de vocês não é a chama...o que vocês variaram não era a chama

então..qual que era o objetivo de vocês?

Al: A água que...

$P: I s s o$

AL1: O que era para variar era a água

AL1: Temperatura da água mas o que variou foi a chama

P:Por que vocês colocaram gelo na água?

P:Para variar o quê?

P:O material da água...

Al: A temperatura

$P: I s s o$

$P: O$ que que vocês querem avaliar?

$P: E u$ quero que vocês formalizem a pergunta

$P: Q u a l$ que é o efeito da...

Al: Da temperatura sobre a ebulição

P:Isso da temperatura inicial do material sobre o que da ebulição?

Al: Quanto tempo demora

$P:$ Quanto tempo demora e o que mais?

AL1: A que temperatura

$P: I s s o$ a que temperatura ocorre a ebulição

Este episódio mostra que este grupo de alunos permanece com dificuldades em compreender o que estavam analisando. Matthews (1994), adverte que a emissão, interpretação e teste das hipóteses são etapas difíceis para alguns alunos e que não se trata de um processo direto nem suficientemente simples. Desta forma, a intervenção da professora é de extrema importância para conduzir os alunos ao raciocínio adequado e estimulá-los a não desistirem do desafio.

O aluno 1 também se refere ao fato de a chama do bico de Bunsen não ter se mantido constante e ter afetado os resultados. A idéia do aluno faz sentido, uma vez que o grupo utilizou bicos de Bunsen com diferentes intensidades de chama para investigar a temperatura de ebulição da água ambiente e gelada; o que fez o aluno sugerir uma segunda variável para o problema e obter o resultado inverso ao esperado. Também, os alunos até o momento não verificaram que a temperatura de ebulição obtida foi a mesma, por mais que o resultado em relação ao tempo para atingir a temperatura de ebulição tenha 
sido o inverso ao previsto por eles. A discussão do grupo com a professora prossegue, conforme mostra o episódio abaixo:

P: "De acordo com os resultados obtidos a água em temperatura ambiente demorou mais para entrar em ebulição do que a água gelada. Esperávamos que o resultado fosse contrário, mas como não tínhamos controle sobre alguns fatores, não podemos discutir nossos resultados obtidos".((professora lê a conclusão dos alunos))

P: Quais fatores... é melhor colocar... a intensidade da chama

Al1: Não não podemos discutir...o resultado foi o inverso do esperado

Al1: Tem a intensidade da chama ((o aluno insiste aqui que o fato o bico de Bunsen ter a chama mais intensa em uma das medidas do que na outra afetou o resultado))

P:Tá Al1 mas...repitam que é melhor

$P:$ Outra coisa aqui vocês analisaram o tempo

P:Que aconteceu com a temperatura de ebulição?

Al: Ficou a mesma

P:Isso ...porque eu tô insistindo tanto nessa pergunta...não só vocês...vários grupos estão analisando totalmente o tempo de ebulição...é importante analisar o tempo...tudo bem é...mas eu não to querendo só o tempo eu tô querendo o tempo na...

AL4: Temperatura

P:Isso Al4 temperatura

$P$ :Então a conclusão ela tem que contemplar além do tempo a temperatura... o que aconteceu com a temperatura de ebulição?

Al: É igual

$P: A$ temperatura inicial do material afeta temperatura na qual ele ferve?

Al4: Não só que ...só o tempo

P:Obrigada Al4

$\mathrm{Na}$ leitura dos resultados pela professora observa-se que os alunos se referem ao tempo que demorou para entrar em ebulição e não à temperatura de ebulição. Os alunos concluem que o resultado foi o inverso do esperado pois esperavam que a água à temperatura ambiente entrasse em ebulição mais rapidamente que a água gelada, porém como a chama não permaneceu constante o resultado foi o inverso. Entretanto, Al 1, e depois, Al 4, expressam seus entendimentos com relação às medidas de temperatura de ebulição obtidas serem iguais, conseguindo analisar as variáveis e elaborar uma conclusão com o auxílio da professora. Esse raciocínio também pode ser verificado nas conclusões elaboradas por escrito pelos alunos. A fim de não prosseguir com as dificultadas apresentadas pelos outros alunos, a professora, então, pede ao grupo que repita o 
experimento. Os alunos o refazem e se agrupam para terminar o relatório. Na execução deste experimento a chama foi controlada, uma vez que os alunos realizaram as medidas de temperatura utilizando o mesmo bico de Bunsen.

Não foram observadas, na re-execução da atividade experimental, discussões relevantes que pudessem contribuir para a análise dos resultados da pesquisa.

Após o término do experimento e discussão entre os alunos e também com o auxílio da professora, os alunos entregaram os relatórios em grupo, para que a professora corrigisse e orientasse a elaboração dos relatórios individuais. Mostram-se, a seguir, as conclusões obtidas pelos grupos :

\section{- Conclusões}

\begin{tabular}{|c|l|}
\hline Grupo & \multicolumn{1}{c|}{ Descrição } \\
\hline $\begin{array}{c}\text { T.inicial } \\
\text { do } \\
\text { material }\end{array}$ & $\begin{array}{l}\text { De acordo com os resultados obtidos, a água em temperatura ambiente demorou } \\
\text { mais tempo para entrar em ebulição do que a água gelada. Esperávamos que o } \\
\text { resultado fosse contrário mas como não tínhamos controle sobre alguns fatores, } \\
\text { não podemos discutir nossos resultados obtidos. } \\
\text { Outro resultado obtido é a relação entre as duas temperaturas dos materiais, que } \\
\text { na inicial tinham temperaturas diferentes, uma com sete graus e outra com vinte e } \\
\text { um graus e ao chegar em ebulição se igualaram a 95 graus. }\end{array}$ \\
\hline $\begin{array}{c}\text { Fonte } \\
\text { de calor }\end{array}$ & A temperatura de ebulição é a mesma só muda o tempo \\
\hline
\end{tabular}

Observa-se que os dois grupos concluíram que a variáveis investigadas não alteraram a temperatura de ebulição, manifestando habilidades cognitivas alta ordem, como análise das variáveis, em suas respostas. O grupo que investigou a temperatura inicial do material relatou a dificuldade encontrada com o controle da chama do bico de Bunsen, uma vez que a água em temperatura ambiente demorou mais para entrar em ebulição do que a água gelada; entretanto, também evidencia habilidades cognitivas ao analisar e selecionar as informações relevantes e concluir que, apesar das amostras apresentarem temperaturas iniciais diferentes, a temperatura de ebulição da água ocorreu em $95{ }^{\circ} \mathrm{C}$ para as duas amostras.

Observa-se que nesta etapa da aula os alunos manifestaram habilidades cognitivas de alta ordem, uma vez que precisaram pensar sobre problema investigado, sintetizar suas idéias, analisando as variáveis avaliadas e refletindo sobre a validade de suas previsões. 


\section{Terceira aula}

É importante recordar que houve uma aula entre a segunda aula e esta (terceira aula), destinada para os grupos que não terminaram o experimento ou as discussões em grupos na primeira aula. Porém, conforme já foi mencionado, essa aula não foi analisada.

$\mathrm{Na}$ terceira aula, a professora pede para que os grupos comuniquem para a sala os resultados e as conclusões obtidas. Os alunos vão para o quadro e escrevem o objetivo e os resultados de cada grupo. A professora também distribui um questionário para que os alunos respondam durante a aula (Anexo $\mathrm{G}$ ).

Este questionário continha três questões que deveriam ser respondidas por todos os alunos integrantes dos grupos para todas as hipóteses investigadas. As questões eram (1) O que foi mantido constante (2) O que foi variado; e a terceira questão envolvia a conclusão do efeito da variável sobre a temperatura de ebulição como, por exemplo:(3) A alteração da temperatura ambiente causa quais modificações no processo de ebulição? (neste caso para o grupo que investigou a variável temperatura ambiente).

As questões (1) e (2) exigiam dos alunos comparar ou contrastar dados e não avaliar ou fazer inferências para a sua resolução, sendo então, classificadas como P2. A questão (3) no entanto, exigia que os alunos analisassem os dados e refletissem sobre as variáveis do problema, sendo então, classificada no nível P3 de cognição. Devido à professora repetir as questões (1) e (2), ou questões análogas, todas as vezes que os grupos discutiam seus dados, o número de questões P2 foi elevado.

Conseqüentemente, as respostas orais dos alunos para as questões (1) e (2) foram diretas e não exigiam esforço cognitivo que os conduzissem a respostas de alta ordem cognitiva, sendo então classificadas como N2, uma vez que o aluno não precisa identificar processos de controle ou variáveis, exigências do N3, para responder por exemplo que, para investigar a temperatura de ebulição de dois materiais diferentes tiveram de manter constante as quantidades e a chama. Entretanto, as respostas dos alunos referentes à questão (3), foram, em grande maioria, classificadas no nível N4 de cognição, pois os alunos precisavam analisar as variáveis do problema e elaborar suas conclusões. Assim, $82 \%$ das questões propostas pela professora $(\mathrm{N}=23)$ foram classificadas como P2 e $75 \%$ das respostas dos alunos ( $\mathrm{N}=36$ ) são de baixa ordem cognitiva (N2).O episódio abaixo exemplifica: 


\begin{tabular}{|c|c|c|}
\hline Tempo & Discurso & Análise \\
\hline 31:07 & P:E qual conclusão que vocês chegaram? & P3 \\
\hline $31: 25$ & $\begin{array}{l}\text { Al15:Que não importa se é maçarico ou lamparina...o que } \\
\text { importa é que vai chegar numa certa temperatura que a água } \\
\text { vai chegar no ponto de ebulição }\end{array}$ & N4 \\
\hline $31: 37$ & $\begin{array}{l}\text { P:Gente o que eles tão chamando de maçarico é o bico de gás } \\
\text { P:Que que eles queriam...se a fonte de calor interferia na } \\
\text { temperatura de ebulição... Al15 acabou de dizer...ou no bico } \\
\text { de gás ou na lamparina a temperatura de ebulição se altera? }\end{array}$ & P3 \\
\hline $32: 00$ & Al15: Não & $\mathrm{N} 2$ \\
\hline $32: 02$ & P:Que altera? & P2 \\
\hline $32: 04$ & Al15: Tempo & $\mathrm{N} 2$ \\
\hline $32: 06$ & P:Que aconteceu com a lamparina? & P2 \\
\hline $32: 12$ & Al15: Demorou mais & $\mathrm{N} 2$ \\
\hline $32: 16$ & $\begin{array}{l}\text { P:Demorou mais.... } \\
\text { P:O que foi mantido constante? } \\
\text { P:O material..que mais? }\end{array}$ & P2 \\
\hline $32: 28$ & Al15: A quantidade né professora? & $\mathrm{N} 2$ \\
\hline $32: 32$ & $\begin{array}{l}\text { P:A quantidade isso...é o mesmo material e a mesma } \\
\text { quantidade } \\
\text { P:O que foi variado? }\end{array}$ & P2 \\
\hline $32: 48$ & Al15: A fonte de calor & $\mathrm{N} 2$ \\
\hline $32: 52$ & Al: O tempo & N1 \\
\hline $32: 56$ & $\begin{array}{l}\text { P:Ai é que ta Al...o tempo foi medido mas o que você variou } \\
\text { intencionalmente...o que você planejou no experimento para } \\
\text { variar ((professora explica para a aluna)) }\end{array}$ & \\
\hline $34: 12$ & $\begin{array}{l}\text { P:A c...a alteração da intensidade da chama causa quais } \\
\text { modificações no processo de ebulição de um material? }\end{array}$ & P2 \\
\hline $34: 20$ & Al15: Tempo & N2 \\
\hline $34: 23$ & P:Muito bem & \\
\hline
\end{tabular}

No tempo 32:52 observa-se que o aluno parece não ter compreendido que o tempo não é a variável a ser investigada, esta dificuldade em compreender que a temperatura é a constante e o tempo é uma conseqüência não é de fácil assimilação pelos alunos.

As questões que a professora propõe nesta etapa da aula parecem não contribuir para que a dificuldade que os alunos apresentam, em não compreender que o tempo não era o objeto do estudo, seja desfeita, ou seja, as perguntas direcionam respostas relacionadas ao tempo que a ebulição demorou. Talvez, se a professora não considerasse o tempo neste experimento essa dificuldade poderia não surgir, uma vez que não há a necessidade de se medir o tempo, a medida da temperatura é suficiente para responder à questão proposta aos alunos.

Entretanto, é importante destacar, conforme mostram os instantes 31:25 à 32:00, que os alunos do grupo que investigou a intensidade da chama compreendem que a temperatura de ebulição não se altera com a fonte de calor, e nos minutos seguintes expressam o entendimento no controle de variáveis ao afirmarem que o material e a quantidade mantiveram-se constantes. Assim, para esse grupo, conforme pode ser verificado também no procedimento inicial, a variável tempo não dificultou a compreensão 
do conceito, ressaltando a relevância dessa atividade para a manifestação de habilidades cognitivas de alta ordem.

Em um outro trecho verifica-se, novamente, a dificuldade dos alunos em compreender que ao se investigar a influência da quantidade de um dado material a temperatura de ebulição é a mesma, porém o tempo para que o material entre em ebulição é diferente. Essa dificuldade ainda pode ser atribuída ao fato de que os valores obtidos para a temperatura de ebulição não foram exatamente iguais:

\begin{tabular}{|c|c|c|}
\hline Tempo & Discurso & Análise \\
\hline 18:23 & $\begin{array}{l}\text { P:Com cento e cinqüenta } \mathrm{mL} \text { a temperatura de ebulição foi } \\
\text { noventa e sete graus e com trezentos } \mathrm{mL} \text { noventa e oito graus } \\
\text { como é que vocês analisam essa diferença? }\end{array}$ & P2 \\
\hline 18:40 & $\begin{array}{l}\text { P:Podem ajudar...quem dá um a opinião...que vocês acham } \\
\text { que dá essa diferença de noventa e sete para noventa e oito? }\end{array}$ & \\
\hline 18:48 & Al17: Não é uma diferença grande & $\mathrm{N} 2$ \\
\hline 18:52 & $\begin{array}{l}\text { P:Não é uma diferença grande } \\
\text { P:A que que a gente poderia atribuir essa diferença? }\end{array}$ & P2 \\
\hline 18:57 & Al4: Variação & N2 \\
\hline 18:58 & $P:$ :De quê? & $\mathrm{P} 2$ \\
\hline 19:00 & Al: Variação do termômetro & N2 \\
\hline 19:01 & $\mathrm{P}:$ Ângulo de leitura às vezes...forma de colocar o termômetro & \\
\hline 19:08 & Al4: Então professora teria que dar o mesmo? & $\mathrm{N} 1$ \\
\hline 19:13 & 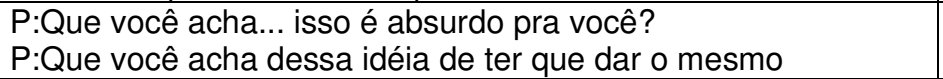 & P3 \\
\hline 19:20 & Al: Mas a quantidade não interfere? & N1 \\
\hline 19:22 & P:Que que você acha? & \\
\hline 19:24 & Al4: A gente chegou a conclusão que não & N3 \\
\hline 19:27 & Al:Não mas dependendo se ela for muito alta & $\mathrm{N} 1$ \\
\hline 19:28 & $\begin{array}{l}\text { Al4: Não Al...se vai aumentando vai ficando constante...se } \\
\text { você for aumentando a temperatura tem que dar a mesma }\end{array}$ & N4 \\
\hline 19:35 & $\begin{array}{l}\text { P:O que que vai mudar? } \\
\text { P:O que vocês observaram que mudou? }\end{array}$ & P2 \\
\hline 19:38 & AL: O tempo & $\mathrm{N} 2$ \\
\hline $19: 40$ & Al4: E a quantidade & N2 \\
\hline 19:44 & $\begin{array}{l}\mathrm{P}: \text { Exatamente ... mudar a quantidade... mudar o volume o que } \\
\text { que afeta? }\end{array}$ & $\mathrm{N} 2$ \\
\hline 19:48 & Al4: Só o tempo & $\mathrm{N} 2$ \\
\hline 19:50 & $\mathrm{P}: \mathrm{E}$ a temperatura? & N2 \\
\hline 19:51 & Al4: E a mesma & N2 \\
\hline 19:53 & $\begin{array}{l}\text { P:Entenderam ou não? } \\
\text { P:Voltando gente...uma coisa que vocês estão com dificuldade } \\
\text { de diferenciar o que que é temperatura e o que é tempo } \\
\text { P:A temperatura vocês mediram com o quê? }\end{array}$ & P2 \\
\hline $20: 07$ & Al4: Termômetro & $\mathrm{N} 2$ \\
\hline $20: 10$ & $\mathrm{P}: \mathrm{O}$ tempo vocês mediram com o quê? & \\
\hline $20: 12$ & Al: Cronômetro & $\mathrm{P} 2$ \\
\hline $20: 14$ & $\begin{array}{l}\text { P:Então oh se vocês olharem a variação da temperatura essa } \\
\text { variação foi grande? }\end{array}$ & N2 \\
\hline $20: 21$ & Al4: Não & N2 \\
\hline $20: 24$ & $\begin{array}{l}\text { P:Não é isso que o grupo tava discutindo? } \\
\text { P:Tanto...dá uma olhada na variação da temperatura da água } \\
\text { e da água com sal... quantos graus variou a temperatura? }\end{array}$ & P2 \\
\hline
\end{tabular}




\begin{tabular}{|l|l|l|}
\hline 20:32 & Al4: Cinco & N2 \\
\hline $20: 40$ & $\begin{array}{l}\text { P:Ali a gente tem uma variação que é de um grau essa } \\
\text { variação de um grau a gente ainda pode considerar variação } \\
\text { de leitura de termômetro por exemplo } \\
\text { P:Então ali é isso que a Al4 tava explicando lá...a gente pode } \\
\text { considerar que a temperatura ficou praticamente constante? }\end{array}$ & P2 \\
\hline $20: 58$ & Al: Sim & N2 \\
\hline $21: 01$ & P:E o que que mudou? & P2 \\
\hline $21: 03$ & Al4: O tempo & N2 \\
\hline
\end{tabular}

Por duas vezes a professora faz um pergunta retórica para a aluna, conforme mostra o tempo 19:08 à 19:22, quando ela expressa a não compreensão sobre a variação nas medidas, exigindo que a aluna utilize os dados obtidos para avaliar as condições e solucionar o problema. Entretanto, a professora não valoriza o argumento da aluna quando essa questiona a variação de $1^{\circ} \mathrm{C}$ nas medidas de temperatura de ebulição ao alterar o volume de uma mesma amostra, perdendo a oportunidade em mediar uma conclusão importante com relação aos objetivos do experimento: o controle de variáveis sobre a temperatura de ebulição de um material. A aluna conclui que a temperatura de ebulição de um material não se altera com a quantidade, mas a professora, ao invés de confirmar e sintetizar as idéias manifestadas por ela, continua a discussão enfatizando a questão do tempo. Em nenhum momento da discussão a professora ou os alunos questionaram o motivo pelo qual o tempo também foi medido, o que pode ter contribuído para que a dificuldade permanecesse.

Verifica-se, nessa aula, que as questões classificadas como P3 são geralmente aquelas que a professora indaga sobre as conclusões obtidas pelos grupos, exigindo assim, que os alunos avaliem os dados. Desta forma, as respostas elaboradas pelos alunos apresentam habilidades cognitivas de alta ordem, como análise de variáveis e seleção de informações, sendo então classificadas como N4.

Nenhuma questão foi classificada no nível N5 de habilidades cognitivas, talvez pelo fato de a professora não proporcionar momentos que exigissem tal nível, ou questões que permitissem a elaboração de respostas com habilidades de generalização.

Em geral, a grande maioria das questões propostas pela professora foi classificada no nível P2 e P3 e as respostas dos alunos nos níveis N2 e N4. É interessante notar que poucas respostas foram classificadas no nível N3 (apenas duas), talvez pelo fato de as aulas exigirem dos alunos maior esforço cognitivo em algumas etapas, como na elaboração de hipóteses e conclusões e, em outras etapas porém, não necessitar de identificação de variáveis ou processos de controle 
por se tratarem de questões diretas e com pouca oportunidade de manifestar respostas mais elaboradas.

Ao analisar os relatórios individuais entregues após as discussões em sala, verifica-se que alguns alunos ainda permanecem com dificuldades em desenvolver previsões e conclusões em que o objeto de estudo seja a temperatura de ebulição, alguns deles, ainda enfatizam o tempo como fator determinante na investigação. É importante relatar que a grande maioria dos relatórios individuais é semelhante ou igual para os integrantes do grupo. A seguir são apresentados alguns exemplos dos relatórios dos alunos:

\section{- Objetivos}

\begin{tabular}{|c|l|}
\hline Grupo & \multicolumn{1}{c|}{ Descrição } \\
\hline $\begin{array}{c}\text { T. inicial } \\
\text { do material }\end{array}$ & $\begin{array}{l}\text { O objetivo era analisar o efeito da temperatura da água sobre o tempo e a } \\
\text { temperatura de ebulição }\end{array}$ \\
\hline $\begin{array}{c}\text { Fonte de } \\
\text { calor }\end{array}$ & Observar se o tempo de "eferveção" afeta a temperatura de ebulição \\
\hline $\begin{array}{c}\text { Fonte } \\
\text { de calor }\end{array}$ & Observar se a fonte de calor afetava o tempo de ebulição e a temperatura \\
\hline Pressão & Verificar a influência da pressão na temperatura da ebulição da água \\
\hline $\begin{array}{l}\text { Quantidade } \\
\text { de material }\end{array}$ & $\begin{array}{l}\text { O objetivo do experimento é descobrir se a temperatura de ebulição muda com } \\
\text { a variação da quantidade de água. Esperamos que as temperaturas sejam as } \\
\text { mesmas, independente da quantidade de água. }\end{array}$ \\
\hline
\end{tabular}

Dois alunos do grupo que investigou a influência da fonte de calor na temperatura de ebulição de um material descreveram seus objetivos como sendo o "tempo de eferveção"; entretanto, por mais que o outro integrante do grupo ainda tenha considerado o tempo, descreveu com clareza a variável investigada como objeto da investigação, ou seja, a influência da fonte de calor sobre a temperatura de ebulição. Os alunos do grupo que investigou a temperatura inicial do material elaboram os objetivos considerando o tempo, mas se fundamentam na idéia principal do experimento, ou seja , a variável investigada. Todos os alunos do grupo que investigou a influência da pressão descreveram corretamente o objetivo do experimento e não consideraram o tempo como objeto de estudo.

Outros alunos de outros grupos, que entregaram somente o relatório individual final, também parecem ter compreendido os objetivos da investigação, manifestando habilidades cognitivas de alta ordem como seleção de informações relevantes e elaboração de hipóteses, conforme evidencia um exemplo de um aluno 
do grupo que investigou a quantidade de material (volume). Nenhum aluno desse grupo expressou o tempo em seus objetivos. Entretanto, não se pode inferir se esse grupo havia compreendido o objetivo do experimento desde o planejamento experimental, ou se a limitada discussão em sala tenha contribuído para que as idéias sobre a influência do tempo fossem compreendidas, uma vez que os integrantes do grupo não devolveram o plano de trabalho prévio da professora.

\section{- Previsões}

\begin{tabular}{|c|l|}
\hline Grupo & \multicolumn{1}{c|}{ Descrição } \\
\hline $\begin{array}{c}\text { T.inicial } \\
\text { do } \\
\text { material }\end{array}$ & $\begin{array}{l}\text { A água em temperatura ambiente seria mais rápida em relação a água gelada } \\
\text { em ebulição }\end{array}$ \\
\hline $\begin{array}{c}\text { Fonte } \\
\text { de calor }\end{array}$ & $\begin{array}{l}\text { Nosso grupo previa que o maçarico esquentaria mais rápido porque o fogo é } \\
\text { mais contínuo; mas quando a água ferve não importa se vai estar no maçarico } \\
\text { ou na lamparina, pois a água já começou a ferver a uma certa temperatura }\end{array}$ \\
\hline
\end{tabular}

Os alunos do experimento da pressão não descreveram suas previsões no relatório final.

Os alunos do experimento que investigou a influência da temperatura ambiente têm dificuldades em construir seu raciocínio para falar que as duas teriam a mesma temperatura de ebulição só que a gelada demoraria mais do que a em temperatura ambiente. Os alunos do experimento da fonte de calor, por outro lado, já tentam fazer uma relação de que a variável investigada não altera a temperatura de ebulição.

Com relação à descrição dos materiais, como a professora já havia corrigido os procedimentos prévios e os relatórios em grupos, os alunos apresentaram as vidrarias utilizadas com os devidos nomes utilizados nos laboratórios.

\section{- Procedimento}

\begin{tabular}{|l|l|}
\hline Grupo & \multicolumn{1}{|c|}{ Descrição } \\
\hline $\begin{array}{c}\text { T.inicial } \\
\text { do } \\
\text { material }\end{array}$ & $\begin{array}{l}\text { Colocamos } 200 \mathrm{~mL} \text { de água gelada em um dos béqueres e } 200 \mathrm{~mL} \text { de água (a } \\
\text { temperatura ambiente), em outro béquer, levamos ao fogo os dois béqueres } \\
\text { com a água e cronometramos o tempo que as duas levam para ferver. } \\
\text { Mediremos a temperatura tanto antes quanto depois da ebulição com o } \\
\text { termômetro. }\end{array}$ \\
\hline $\begin{array}{l}\text { Fonte } \\
\text { de calor }\end{array}$ & $\begin{array}{l}\text { Coloque } 100 \mathrm{~mL} \text { de água em um béquer e coloque-o em cima do tripé que } \\
\text { estará sobre um maçarico. Acenda o maçarico e espere por } 15 \text { minutos, } \\
\text { enquanto isso vá medido a temperatura da água, após } 15 \text { minutos você mede a } \\
\text { temperatura. } \\
\text { Coloque } 100 \mathrm{~mL} \text { de água em um béquer e coloque-o em cima do tripé que } \\
\text { estará sobre uma lamparina. Acenda a lamparina e espere por } 20 \text { minutos. }\end{array}$ \\
\hline
\end{tabular}


\begin{tabular}{l|l}
\hline $\begin{array}{l}\text { Enquanto isso vá medido a temperatura da água, após vinte minutos você mede } \\
\text { a temperatura. }\end{array}$ \\
\hline
\end{tabular}

Os integrantes dos dois grupos indicaram em seus relatórios finais a constante volume, conforme sugeriu a professora após avaliar os planos prévios para a realização do experimento, expressando seus entendimentos quanto ao controle das variáveis do problema. Os alunos do grupo que investigou a temperatura inicial do material enfatizam o tempo para determinar a coleta de dados e não a temperatura de ebulição. Os alunos do experimento da fonte de calor utilizam os dados que obtiveram na realização do experimento na redação do procedimento experimental, ou seja, descrevem que o manipulador terá que esperar 15 minutos para que a água entre em ebulição com o maçarico (bico de Bunsen) e 20 minutos com a lamparina.

\section{- Conclusão}

\begin{tabular}{|l|l|}
\hline Grupo & \multicolumn{1}{|c|}{ Descrição } \\
\hline Pressão & $\begin{array}{l}\text { Após esse experimento concluímos que a pressão influencia na temperatura de } \\
\text { ebulição. Quanto maior a pressão maior será a temperatura de ebulição. }\end{array}$ \\
\hline $\begin{array}{l}\text { Fonte } \\
\text { de calor }\end{array}$ & $\begin{array}{l}\text { O maçarico fez com que a água atingisse a ebulição }\left(92{ }^{\circ} \mathrm{C}\right) \text { em } 15 \text { minutos já a } \\
\text { lamparina ficou acessa durante } 20 \text { minutos para que a água chegasse a } \\
\text { ebulição }\end{array}$ \\
\hline
\end{tabular}

Percebe-se, implicitamente na conclusão de dois alunos do grupo que investigou a fonte de calor, a compreensão com relação à influência das fontes de calor, ou seja, que utilizando o maçarico a água demorou mais para atingir a temperatura de ebulição do que com o bico de Bunsen. Ainda, os alunos expressam o entendimento do conceito ao descreverem a temperatura encontrada para a ebulição, tanto com o maçarico quanto com o bico de Bunsen. Assim, os alunos concluem que a temperatura de ebulição da água será a mesma quando aquecida por diferentes fontes de calor; somente afetando o tempo para que o fenômeno ocorra.

Todos os alunos do experimento da temperatura ambiente colocaram a mesma conclusão contida no relatório de grupo. Todos os alunos que investigaram a influência da pressão sobre a temperatura de ebulição, descreveram a mesma conclusão apresentada acima.

O grupo que investigou a pressão foi o que encontrou maiores dificuldades manipulativas e conceituais. $\mathrm{O}$ experimento consistiu em aquecer água em um balão com 
saída lateral. Quando a água atingiu a temperatura de ebulição, a mangueira foi fechada com uma pinça, o balão invertido e no seu fundo foi colocado um pano umidecido com água gelada.

Durante a discussão realizada na terceira aula, verifica-se que a maioria dos alunos da sala não compreendeu o procedimento experimental realizado e a explicações conceituais para a elaboração das conclusões. Assim, a professora disponibiliza uma quarta aula para realizar novamente o experimento e discutir com os alunos.

\section{Quarta aula}

Na última aula sobre temperatura de ebulição, a professora retoma a explicação sobre a influência da pressão na temperatura de ebulição. No início da aula, a professora questiona os alunos sobre quais fatores afetam a temperatura de ebulição de um material, e os alunos respondem: "material" e "pressão". É importante salientar que neste momento nenhum aluno sugere tempo ou outra variável investigada no experimento, o que pode indicar a compreensão do conceito pelos alunos, mas ao mesmo tempo, o motivo de não apontarem outros fatores pode estar relacionado simplesmente ao fato de os alunos não comunicarem suas idéias durante a aula.

A professora, então, discute com os alunos a influência da pressão na temperatura de ebulição, mas é evidente a dificuldade de compreensão por parte dos alunos. Um aluno participa mais e exprime suas idéias com relação ao fenômeno. Quando a professora compara um recipiente aberto com um fechado, pergunta aos alunos qual deles dificulta a formação de vapor; o aluno responde fazendo uma analogia com o aumento ou diminuição do espaço:

A11: Tem menos espaço...o acúmulo de vapor não dá espaço para mais vapor se formar.

Durante uma entrevista, após o término dos experimentos, a pesquisadora questionou a professora quanto aos objetivos do experimento da temperatura de ebulição, e se estes haviam sido ou não alcançados; conforme segue descrito a seguir: 
Pesquisadora: Com quais objetivos você elaborou o experimento da temperatura de ebulição?

Professora: Levar os alunos a refletirem sobre as idéias que traziam a respeito da temperatura de ebulição dos materiais e compreender os fatores que a afetam.

Pesquisadora: Você considera que foram atingidos?

Professora: Parcialmente [...] Os alunos não compreenderam a influência da pressão sobre a temperatura de ebulição dos materiais. Isso pode ter ocorrido em função da não compreensão do experimento. O mecanismo adotado durante a atividade para a redução da pressão não é óbvio e exige um certo grau de abstração que não foi atingido pelos alunos naquele momento.Esse ponto será retomado novamente para que os alunos tenham a oportunidade de refletir novamente sobre ele.

A fala da professora corrobora a análise dos dados, ou seja, o entendimento da influência da pressão sobre a temperatura de ebulição não foi alcançado, o que pode estar relacionado com o grau de abstração que tal idéia parece exigir e, também, pelo fato de os alunos criarem seus modelos ainda em nível macroscópico. Também, o não entendimento da variável pelos alunos pode estar relacionado à complexidade do procedimento experimental, o que pode ter contribuído para que os alunos não o compreendessem conceitualmente. Ainda, conforme a professora relata, este tópico será retomado em outra situação com maiores possibilidades de compreensão conceitual.

Depois desta discussão com os alunos, a professora volta à pergunta inicial, realizada na primeira aula: "Como podemos identificar um material?", e pede para que os alunos respondam a seguinte pergunta individualmente em uma folha para ser entregue: "A temperatura de ebulição pode ser utilizada para identificar um material?".

A professora pretendia que os alunos respondessem que materiais diferentes possuem temperaturas de ebulição diferentes. Dezoito alunos entregaram a questão respondida. Um aluno sugere que alguns materiais podem apresentar temperaturas de ebulição próximas, o que dificultaria a sua identificação: 


\begin{tabular}{|l|l|l|}
\hline \multicolumn{1}{|c|}{ Aluno } & \multicolumn{1}{|c|}{ Resposta } & Análise \\
\hline Aluno 17 & $\begin{array}{l}\text { Não, pois pode ter materiais } \\
\text { com valores próximos. }\end{array}$ & N3 \\
\hline
\end{tabular}

Neste caso, o aluno explica o problema, mas não faz uma relação de que a temperatura de ebulição pode auxiliar na identificação do material, mesmo os valores sendo parecidos se conhecer outras propriedades, como por exemplo, a densidade.

Dez alunos responderam o esperado pela professora:

\begin{tabular}{|l|l|l|}
\hline \multicolumn{1}{|c|}{ Aluno } & \multicolumn{1}{|c|}{ Resposta } & Análise \\
\hline Aluno 4 & $\begin{array}{l}\text { A temperatura de ebulição pode } \\
\text { auxiliar na identificação do } \\
\text { material porque cada material } \\
\text { tem uma temperatura de } \\
\text { ebulição. }\end{array}$ & N3 \\
\hline Aluno 13 & $\begin{array}{l}\text { Sim, porque cada material tem } \\
\text { uma temperatura diferente }\end{array}$ & N3 \\
\hline
\end{tabular}

Um aluno analisa as variáveis do problema, uma vez que sugere, em sua resposta, que a temperatura de ebulição pode ser uma hipótese para a sua identificação e não a única e definitiva variável a ser analisada:

\begin{tabular}{|l|l|l|}
\hline \multicolumn{1}{|c|}{ Alunos } & \multicolumn{1}{c|}{ Respostas } & Análise \\
\hline Aluno 18 & $\begin{array}{l}\text { Pode se sabemos a temperatura } \\
\text { de ebulição de um material, } \\
\text { podemos usar isso como } \\
\text { hipótese para caracterizá-lo. }\end{array}$ & $N$ \\
\hline
\end{tabular}

Seis alunos respondem com habilidades do nível $\mathrm{N} 1$, ou seja, ou não compreenderam o problema ou expressam somente dados relembrados.

\begin{tabular}{|l|l|l|}
\hline \multicolumn{1}{|c|}{ Aluno } & \multicolumn{1}{|c|}{ Respostas } & Análise \\
\hline Aluno 5 & $\begin{array}{l}\text { Não, porque cada material pode } \\
\text { ter uma temperatura para ficar } \\
\text { em ebulição, pois ele consiste } \\
\text { em um material diferente }\end{array}$ & $N$ \\
\hline Aluno 11 & $\begin{array}{l}\text { Sim, porque dependendo do } \\
\text { material ele pode demorar ou } \\
\text { entrar em ebulição com isso } \\
\text { facilita a identificação }\end{array}$ & $N 1$ \\
\hline
\end{tabular}

Ao analisar as respostas dos alunos, verifica-se que alguns se detêm ao experimento realizado e não analisam a pergunta de uma forma mais global; ou seja, 
não criam um raciocínio englobando o conhecimento construído no experimento de densidade e na temperatura de ebulição. No experimento de densidade esta pergunta foi feita e os alunos, durante o experimento, responderam que somente com a densidade não era possível identificar um material pois alguns poderiam ter densidades parecidas ou, algumas vezes, justificavam que com o auxílio de uma tabela comparativa, a densidade poderia ajudar na identificação de um material. Assim, poderíamos esperar que os alunos também estabelecessem essa relação para o conceito de temperatura de ebulição. Entretanto, as respostas dos alunos estão de acordo com a questão proposta pela professora e a grande maioria foi classificada no nível N3 de cognição.

\subsubsection{Consideração sobre a atividade experimental investigativa: T. E.}

Ao analisar a atividade proposta pela professora A para a primeira série I sobre o conceito de temperatura de ebulição, verifica-se que a atividade apresenta as características de uma atividade investigativa, na qual o aluno participa ativamente da construção do conhecimento, opinando, discutindo e propondo hipóteses para a solução do problema.

De acordo com Carvalho et al. (1999), para que a atividade experimental tenha caráter investigativo e possa ser considerada uma atividade de investigação, a ação do aluno não deve se limitar apenas ao trabalho de manipulação ou observação, a resolução de um problema pela experimentação deve envolver também reflexões, relatos, discussões, ponderações e explicações características de uma investigação científica.

Assim, partindo de uma questão problema, proposta pela professora, os alunos tiveram a oportunidade de elaborar suas hipóteses, planejar o procedimento experimental, coletar dados, analisá-los, discutir as conclusões com os pares, errar e localizar a causa do erro a fim de procurar uma nova metodologia para sua solução. Para Pintrich e colaboradores (1993), entre os fatores capazes de proporcionar o desenvolvimento de habilidades cognitivas estão a seleção e ativação do conhecimento prévio, o desenvolvimento de habilidades de processamento, a elaboração e organização, a resolução de problemas e a utilização de habilidades cognitivas de controle e regulação.

A professora pôde, através da proposição de hipóteses, evidenciar as idéias alternativas que os alunos apresentavam sobre temperatura de ebulição e os fatores que o modificavam. Por mais que algumas dificuldades ainda tenham persistido, 
como a relação do tempo com a temperatura e a influência da pressão na temperatura de ebulição, considera-se que os alunos compreenderam que a temperatura de ebulição não é afetada pela massa, nem pelo volume e nem pela intensidade da chama utilizada no aquecimento do material e que materiais diferentes possuem temperaturas de ebulição diferentes; aspectos que respondem à questão inicial proposta pela professora.

Apesar das dificuldades enfrentadas pelos alunos na elaboração do planejamento e execução do experimento, eles demonstraram interesse pela investigação e manifestaram habilidades cognitivas de alta ordem como elaboração de hipóteses e análise de dados e variáveis para a sua confirmação ou refutação.

Segundo Hodson (1988), o papel das hipóteses é de fundamental importância nas atividades experimentais, pois pode exigir capacidade criativa e elaboração conceitual por parte dos alunos. A elaboração de hipóteses exerce um papel fundamental para a construção do conhecimento científico pois está vinculada à elaboração de estratégias para a coleta e análise de dados e conseqüentemente à resolução de uma situação problema. É preciso haver previsões plausíveis de serem refutadas ou confirmadas para se analisar os dados. Assim, a elaboração de hipóteses exige grande demanda cognitiva e pode contribuir para o desenvolvimento conceitual do aluno. Jenkins (2000) afirma que, na procura de entender um fenômeno, muitos estudantes não apresentam uma inteligível diferenciação entre o significado de uma hipótese científica e o que é proposto por eles como explicação.

Pode-se considerar que, o papel da professora foi de fundamental importância, pois em nenhum momento ela refutou ou comprovou as hipóteses, sempre privilegiando o momento de criação e imaginação dos alunos. Quando se trata de uma questão "errada", a professora corrige e explica os motivos. Esse momento é muito importante pois a professora não pode dar a resposta para não desvalorizar o trabalho que será realizado por eles, mas também deve manter o controle e percepção para não desestimular os alunos para a investigação do problema, permitindo que eles próprios tomem suas decisões.

A dificuldade encontrada pelos alunos para relacionar o tempo com a temperatura de ebulição poderia ter sido evitado ou atenuado caso uma discussão mais detalhada sobre a razão da influência dessa variável sobre as variáveis sugeridas para investigação tivesse ocorrido. As medidas de tempo e temperatura são comuns nesse tipo de experimento para auxiliar os alunos a perceberem que a 
ebulição ocorre em uma determinada temperatura, e a influência de outras variáveis, como as investigadas nessa atividade, ocorre somente no tempo. Entretanto, alguns alunos descreveram o tempo como determinante na investigação, ainda, sem que essa variável tivesse sido sugerida pela professora ou pelos alunos. Também, o próprio procedimento experimental em que o aluno, além de coletar medidas de temperatura também coletava medidas e tempo inicial e final, pode ter contribuído para que o aluno não compreendesse com clareza o objetivo do experimento.

Um experimento semelhante foi realizado por Carvalho et al. (1999), entretanto, os autores se atentaram em discutir com os alunos a importância de saber o que acontecia durante o experimento e não apenas no final para que eles citassem e avaliassem a necessidade de um cronômetro na execução de um experimento. $\mathrm{Na}$ atividade investigada nesta dissertação, os alunos, com o consentimento da professora, coletaram somente o tempo inicial e temperatura inicial da amostra e o tempo e a temperatura atingida na ebulição. Talvez, esse fato possa ter contribuído para que os alunos dirigissem suas atenções para a temperatura de ebulição e o tempo, em detrimento da relação entre a variável investigada e a temperatura de ebulição ao descreverem seus planos de trabalho e relatórios.

Uma consideração a ser feita se refere à intervenção da professora em alguns momentos da aula. Durante o levantamento de hipóteses e conclusões, a professora auxiliava os alunos na construção de suas explicações, pois muitas vezes os alunos não conseguiam explicitar suas idéias de maneira inteligível, necessitando do auxílio da professora para a elaboração de uma resposta mais completa. Entretanto, durante a elaboração dos relatórios, a presença da professora não era integral nos grupos, e os alunos precisavam utilizar suas própria idéias e sintetizá-las de forma a permitir que outra pessoa as compreendesse e esta etapa exige, como já foi mencionado, elevada demanda cognitiva e também autonomia e independência por parte dos estudantes, o que pode ter contribuído para a dificuldade encontrada em argumentar suas idéias por escrito. Deve ser lembrado que esse exercício exige habilidades de síntese e clareza nas informações descritas; o que sugere um investimento em atividades que privilegiem o desenvolvimento da habilidade da escrita (RIVARD; STRAW, 2000).

É importante relatar também que a professora valoriza a fala do aluno, oferecendo tempo e oportunidade para eles expressarem suas idéias, conforme evidenciam os episódios de aula. Na grande maioria dos questionamentos da 
professora, há uma idéia ou argumento de um aluno em seguida. O diálogo entre professor-aluno e aluno-aluno pode ajudar os estudantes a pensar criticamente. $O$ professor precisa demonstrar para os estudantes como conduzir as variáveis da investigação, tal como, questionar, coletar dados, analisar os resultados e elaborar explicações.

É importante relatar que, por mais que a professora obedecesse a um planejamento escolar, esse fator não influenciou o desenvolvimento da atividade, uma vez que ela não se preocupava apenas com conteúdo dado, mas com a compreensão deste pelos alunos. Apesar de a atividade ter consumido um número elevado de aulas (cinco aulas), os alunos puderam participar de uma atividade que exigiu habilidades cognitivas de alta ordem; o contato com processos típicos de uma investigação científica, como elaboração e interpretação das hipóteses; comunicação e discussão das conclusões obtidas; capacidade de argumentação oral e escrita.

Uma evidência da eficácia da atividade se manifestou na fala dos alunos durante uma entrevista realizada, quatro semanas após a realização da atividade, com dez estudantes (Anexo $\mathrm{H}$ ). Os alunos expressavam a compreensão dos conceitos envolvidos no experimento, conforme mostra a fala de um dos alunos:

Al 13: É... por exemplo você pode colocar qualquer quantidade de água que vai mudar... O ponto de ebulição vai ser o mesmo vai mudar só o tempo... mas o ponto de ebulição é o mesmo.

Os alunos também argumentam a importância e preferência pela realização do procedimento experimental a da participação em todas as etapas da atividade. $A$ Al 9 comenta a importância da mediação da professora durante a realização da investigação:

Al 9: É eu gostei porque a gente tem uma certa liberdade e também não foi tão... Com eu posso falar...não foi tão disperso... a gente já tinha uma direção, mas mesmo assim a gente tava livre pra escolher o que que a gente ia fazer... a gente escolhia o caminho e a professora ia guiando a gente... e a gente acabou fazendo tudo certinho...e saiu do jeito que a gente esperava ainda.

Al 16: Foi um pouco trabalhoso, só que no final foi legal e você sabe o que você ta fazendo ali...foi o que você pensou...e sabe o que você vai fazer [...] É que é mais interessante, mais legal você mesmo investigar, você não saber o que que tem... fazer por conta própria. 
Uma aluna também cita a importância da elaboração de um relatório para a aprendizagem:

Al 11: Até o relatório é legal para ver se entendeu mesmo se todo mundo compreendeu... aí você vê porque não deu certo o que a gente pensava e tal.

Assim, se essas atividades forem utilizadas de maneira a aproveitar seus aspectos favoráveis, respeitando os limites conceituas dos alunos, mas, permitindo que eles estejam ativos no processo de resolução do problema, podem contribuir para a construção de conhecimentos químicos e o desenvolvimento de habilidades cognitivas necessárias para a formação de indivíduos críticos e com atitude, exigidos por nossa sociedade em constante transformação.

\subsection{Escola B}

\subsubsection{Experimento: Temperatura de Fusão}

\section{Primeira aula - Execução do experimento}

$\mathrm{Na}$ primeira aula, a professora realizou o experimento para determinar a temperatura de fusão de substâncias e misturas de substâncias. Para isso, ela inicia a aula recordando com os alunos a atividade experimental realizada nas últimas aulas sobre o conceito de temperatura de ebulição. Essas aulas tinham como objetivo que os alunos fossem capazes de:

- $\quad$ definir o que é uma substância;

- $\quad$ julgar se o ponto de ebulição de uma substância pode ser considerado uma constante física;

verificar se o ponto de ebulição pode ser utilizado para caracterizar uma substância e distinguí-la de uma mistura.

Assim, os alunos tiveram a oportunidade de realizar o experimento da temperatura de ebulição da água e da água contendo glicerina, construir os gráficos para a análise dos dados e responder aos objetivos propostos no início da atividade. Porém, estas aulas não foram gravadas e acompanhadas pela pesquisadora. 
Após recordar as curvas que representam a variação da temperatura em função do tempo de aquecimento para misturas de substâncias e substâncias, a professora procura fazer com que os alunos relembrem o que é fusão:

P:Tem que atingir o ponto de fusão...mas como é que ele ((o material)) tem que estar antes de atingir o ponto de fusão e depois de atingir o ponto de fusão?

$P:$ Como ele tá antes?

Al 3: Sólido

P:Sólido... depois fica... líquido

$P$ :Então como que se calcula o ponto de fusão?

P:Quando um material está sólido para ...

Al: Líquido

A professora então lê com os alunos a introdução sobre o conceito temperatura de fusão contidas no material, e propõe os problemas a serem investigados:

- $\quad$ redefinir o que é uma substância

- comparar o ponto de fusão e o ponto de solidificação de uma substância;

verificar se o ponto de fusão é uma constante física;

verificar se o ponto de fusão pode ser utilizado para identificar uma substância e distinguí-la de uma mistura.

Em seguida, a professora lê o procedimento e os alunos, separados em grupos, realizam o experimento. Formaram-se quatro grupos de aproximadamente quatro ou cinco alunos em cada. Dois grupos investigaram a temperatura de fusão da parafina e os outros dois grupos investigaram a temperatura de fusão da naftalina. Os alunos tiveram cerca de quarenta minutos para realizar o experimento. É importante relatar que nesta aula aproximadamente quinze ou vinte alunos estavam ausentes.

No experimento, os alunos deveriam aquecer uma certa quantidade do material investigado e registrar a cada quinze segundos a temperatura alcançada para que, posteriormente, construíssem um gráfico e analisassem as diferenças dos gráficos de uma substância (naftalina) e de uma mistura de substâncias (parafina). Com o material já fundido, os alunos deveriam, também, registrar a diminuição da temperatura em função do tempo até que ocorresse a solidificação dos materiais. 
Os alunos não encontraram muitas dificuldades para a realização do experimento, uma vez que se trata de um experimento de simples manipulação. As duas maiores dificuldades observadas estão na leitura do termômetro e na sincronia no controle da medida do tempo e da leitura do termômetro.

A professora, durante toda a aula, se preocupa com o desenvolvimento do experimento e passa pelos grupos verificando se os alunos estão anotando os dados e observações relevantes.

No entanto, a professora não problematizou os objetivos do experimento com os alunos e não conduziu perguntas ou desafios que os fizessem pensar sobre o problema, podendo assim, propor suas hipóteses para possíveis respostas.

\section{Segunda aula - Elaboração dos gráficos}

Após a coleta dos dados realizada na primeira aula, a professora inicia a segunda aula recordando a construção de um gráfico:

P: O que a gente coloca no eixo y...lembram do ponto de ebulição...o que a gente colocou ali?

Al: Temperatura

P:O que a gente mediu no relógio?

Al: Tempo

A professora vai ao quadro esboçar um gráfico para auxiliar os alunos na construção de seus gráficos individuais. No mesmo papel milimetrado, os alunos deveriam representar, as curvas de fusão e do resfriamento do material investigado. O episódio a seguir mostra a discussão em sala:

$P: A$ fusão...quem fez a parafina?

$P:$ Em que temperatura aconteceu o inicio da fusão?

Al: Sessenta

$P:$ Em que minuto?

P:Dá uma olhadinha aí

P:Vocês entenderam a medida aqui em baixo entenderam o que vocês vão fazer...coloquem de trinta em trinta

$P: Q u a n d o$ aconteceu o inicio da fusão?

Al4: Sessenta 


\section{$P:$ No sessenta}

P:Vocês vão colocar todos os pontinhos que vocês acharam

$P$ :Esse ponto aqui vocês vão indicar o quê? ((professora indica o início da fusão no esboço do gráfico))

P:O que começou aqui?

Al2: Fusão

$P:$ Depois onde foi o término da fusão?

$P:$ Vamos dizer que tenha sido nos oitenta graus

$P:$ Lá nos dez minutos

$P: O$ que vocês vão escrever aqui?

Al: Término

P:Término

P:Vocês vão colocando todos os pontinhos que vocês mediram lá no experimento

P:Inclusive início da fusão término da fusão

P:Não esqueçam de traçar a reta

Devido a muitos alunos terem se ausentado na aula anterior, a professora pediu para formar grupos para que todos tivessem acesso aos dados para a construção dos gráficos. Os quarenta e cinco minutos restantes da aula foram dedicados para a construção dos gráficos pelos alunos.

Durante a aula, observa-se uma dificuldade por parte dos alunos na construção das escalas, principalmente porque os dados foram coletados a cada quinze segundos e os alunos deveriam construir as escalas de temperatura a cada trinta segundos. Os alunos também apresentam dificuldades para escolher os melhores pontos e traçar a reta da fusão e da solidificação. Ao analisar os gráficos entregues pelos alunos, verifica-se que muitos deles não traçaram as retas, somente marcaram os pontos obtidos.

Pode-se perceber que, nessas duas primeiras aulas, houve pouco diálogo da professora com os alunos, o que dificulta a classificação das perguntas da professora e repostas dos alunos nas categorias elaboradas. A execução do experimento se tornou uma etapa mecânica, pois os alunos apenas coletaram medidas de temperatura em função do tempo e não foram estimulados pela professora para hipotetizar ou pensar sobre o problema que estavam investigando, o que poderia evidenciar a manifestação de habilidades cognitivas de alta ordem. A construção do gráfico, no entanto, exigiu dos alunos selecionar os melhores pontos para traçar a reta de fusão e solidificação, habilidades cognitivas de ordem superior. 
As próximas aulas evidenciarão, como será mostrado, um maior diálogo entre professora e alunos, e maior manifestação de habilidades cognitivas ou algorítmicas por se tratar da etapa de análise dos dados e questões para discussão.

\section{Terceira aula - Análise dos dados e conclusões}

A professora havia pedido, na aula anterior, que os alunos tentassem responder às questões propostas no material quanto à análise dos dados; então, inicia a aula lendo as questões do material (Anexo I) e discutindo os resultados com os alunos.

O primeiro exercício está relacionado à construção do gráfico: "Construa no papel milimetrado o gráfico que representa o aquecimento da naftalina e o que representa o seu resfriamento, colocando a temperatura em ordenadas e o tempo em abscissas. Construa também, os gráficos que representam o aquecimento e 0 resfriamento da parafina num outro papel milimetrado".

A professora, então, começa a discussão com os alunos sobre a construção do gráfico e vai discutindo paralelamente a questão 2: "Indique o estado físico do material para cada ponto do gráfico". Esta questão foi classificada como P2, por exigir que o aluno compare os dados, aplique as leis e conhecimentos construídos nestas aulas para a resolução do problema.

A resolução desses dois primeiros exercícios fez com que a professora propusesse algumas outras questões para o seu entendimento. Essas questões se referiam à curva do gráfico de fusão e solidificação, porém somente a construção do gráfico da parafina foi discutida em sala de aula.

Das questões propostas pela professora durante a discussão das duas questões apresentadas no material, $73 \%$ foram classificadas como $\mathrm{P} 1$, como por exemplo: Mediu até quanto?Antes de derreter estava em qual estado físico?

Essas questões não exigiam que os alunos comparassem os dados ou os contrastassem, apenas são questões operacionais que são relembradas utilizando os dados obtidos. O restante das questões foi classifica como P2 pois se referem a questões que exigem a aplicação de leis, como por exemplo: Qual estado físico eu tenho durante a fusão? Ou seja, o aluno precisa reconhecer o início e término da fusão e solidificação para poder responder ao problema. 
Com relação às respostas dos alunos para estas questões, $80 \%$ foram classificas como N2, pois os alunos compreendiam a questão mas respondiam pontualmente, sem identificar variáveis ou justificando as suas respostas, como por exemplo: Al: Líquido; Al1: Noventa graus. O número total de questões propostas e respostas elaboradas pelos alunos durante a terceira aula, assim como os níveis cognitivos nos quais essas questões foram classificadas, encontram-se nas figuras 8 e 9 (vide página 164).

Duas questões foram classificadas como N3 pois os alunos identificaram os processos de controle para sua resolução ou porque justificaram suas respostas utilizando os conceitos exigidos; o restante foi classificado como N2. O episódio abaixo exemplifica a análise:

\begin{tabular}{|l|l|l|}
\hline Tempo & \multicolumn{1}{|c|}{ Discurso } & \multicolumn{1}{c|}{ Análise } \\
\hline $13: 10$ & $\begin{array}{l}\text { P:Eu tenho líquido? } \\
\text { P:Tenho...porque começou a fusão mas o que eu tenho também } \\
\text { por que a fusão não terminou? } \\
\text { P:Por que eu tenho sólido aqui ainda? }\end{array}$ & P2 \\
\hline $13: 26$ & Al1: Porque ainda não...não terminou a fusão & N3 \\
\hline
\end{tabular}

Porém, conforme mencionado anteriormente, a professora faz em sala de aula somente o gráfico de fusão e resfriamento da parafina, e um dos objetivos propostos no início da aula era o de verificar se a temperatura de fusão pode ser utilizada para identificar uma substância e distinguí-la de uma mistura. Como esta análise não foi realizada, os alunos não tiveram a oportunidade de analisar os dois gráficos e selecionar as informações relevantes para propor hipóteses e soluções para o problema, situações em que poderiam ter manifestado habilidades cognitivas de alta ordem.

A professora verificou, após o término da aula, ao receber os gráficos construídos pelos alunos, que os gráficos de fusão e solidificação da naftalina elaborados não concordavam com os resultados esperados, ou seja, os gráficos apresentavam características de um gráfico de uma mistura de substâncias e não de uma substância. A professora então, realizou uma quarta aula para refazer o experimento e coletar novamente os dados e construiu com os alunos um novo gráfico.

A professora apontou a possibilidade de o erro ser devido ao fato de a naftalina não estar bem triturada ou, talvez, ao fato de os alunos terem retirado o 
termômetro do tubo de ensaio com a amostra para efetuar a leitura da temperatura durante a execução do experimento realizado na primeira aula.

Essa aula não pôde ser registrada por motivos de saúde da pesquisadora.

Em seguida, a professora propõe a terceira questão do material: "Qual a temperatura em que ocorre a solidificação da naftalina? E da parafina?Verifique nos gráficos e compare com os resultados das outras equipes".

Esta questão também foi classificada como P2, pois exige que os alunos comparem os dados no gráfico aplicando os conceitos para a sua resolução.

Durante a discussão, a professora propõe outras questões para discussão, todas classificadas como P2, e as respostas dos alunos exibiram habilidades cognitivas de baixa ordem (N2), conforme exemplifica o diálogo abaixo:

\begin{tabular}{|l|l|l|}
\hline \multicolumn{1}{|c|}{ Tempo } & \multicolumn{1}{|c|}{ Discurso } & \multicolumn{1}{c|}{ Análise } \\
\hline $23: 54$ & P:Então qual a temperatura de solidificação da parafina? & N2 \\
\hline $24: 22$ & Al: Oitenta e oito e .... & P2 \\
\hline $24: 26$ & Al: Sessenta e dois & \\
\hline $24: 37$ & P:Sessenta e dois é o que...o início ou termino da solidificação? & P2 \\
\hline $24: 38$ & Al: Início & \\
\hline $24: 43$ & $\begin{array}{l}\text { P:Foi exatamente no sessenta e dois ou entre o sessenta e dois e } \\
\text { algum valor? } \\
\text { P:Começou a solidificar no sessenta e dois e terminou aonde? }\end{array}$ & P2 \\
\hline $24: 53$ & Al 4: Cinqüenta & N2 \\
\hline $24: 55$ & Al: Cinqüenta e oito & P2 \\
\hline
\end{tabular}

A professora, nesse momento, também não questiona os alunos quanto às variações de medidas e também não compara os gráficos, ou seja, quais são as diferenças entre os dois gráficos, como se pode identificar uma substância e uma mistura de substâncias analisando os dois gráficos. Essa discussão poderia ter gerado questões e respostas de alta ordem cognitiva, permitindo que os alunos analisassem as variáveis e elaborassem hipóteses para a solução do problema; mesmo por que essas questões são os problemas propostos pela professora como investigação.

A quarta questão proposta no material e pela professora é a seguinte:

"A naftalina apresenta um único valor para o ponto de solidificação ? E a parafina?". Essa questão também foi classificada no nível P2.

Nesta questão, a fala da professora prevalece, uma vez que ela explica aos alunos as variações de medidas de temperatura de fusão e solidificação da parafina obtidas pelos grupos: 


\begin{tabular}{|c|c|c|}
\hline Tempo & Discurso & Análise \\
\hline 29:50 & Al: Mas um deu uma coisa e outra deu outra ...medida & N1 \\
\hline 29:58 & $\begin{array}{l}\text { P:Você talvez....a hora que você olhou no termômetro você olhou } \\
\text { cinqüenta...é só um erro de observação...mas se você olhar o } \\
\text { intervalo aqui você vai ver que está bem semelhante... } \\
\text { P:E só erro de observação } \\
\text { P:Ocorreu exatamente aqui }\end{array}$ & \\
\hline $30: 45$ & $\begin{array}{l}\text { P:E só erro de observação } \\
\text { P:O que vocês tem que considerar que tem de interferência no } \\
\text { laboratório? } \\
\text { P:Primeiro a atenção em relação ao que você está medindo em } \\
\text { relação à observação do termômetro } \\
\text { P:Você pode ter observado de uma forma e elas de outra...então } \\
\text { quando você olhou no termômetro você viu cinqüenta e elas } \\
\text { quarenta e nove...são próximos...não está errado } \\
\text { P:Mas tem várias coisas que puderam influenciar no ponto de } \\
\text { solidificação } \\
\text { P:O processo de solidificação... }\end{array}$ & \\
\hline $33: 14$ & $\begin{array}{l}\text { P:Aqui na parafina ocorreu a solidificação num valor só num ponto } \\
\text { só? } \\
\text { P:Foi instantâneo ou ocorreu num intervalo...começou a solidificar } \\
\text { e terminou...começou numa temperatura e terminou? } \\
\text { P:Dá para perceber que aconteceu num intervalo? } \\
\text { P:Mas tudo solidificou onde? } \\
\text { P:Dá para perceber que aconteceu num intervalo } \\
\text { P:Aqui começou a solidificar em setenta e dois e disseram que } \\
\text { terminou onde no cinqüenta } \\
\text { P:Os valores dos outros grupos estão próximos .... }\end{array}$ & \\
\hline $34: 30$ & $\begin{array}{l}\text { P:A parafina apresenta um único valor para o ponto de } \\
\text { solidificação? } \\
\text { P:Sim ou não? }\end{array}$ & \\
\hline $34: 36$ & $\begin{array}{l}\text { P:Coloquem a observação de vocês e a resposta que vocês } \\
\text { chegaram } \\
\text { P:Explique por que vocês acham que tem um ponto só ou não }\end{array}$ & \\
\hline
\end{tabular}

Nesse momento a professora explica as interferências que poderiam ter afetado as medidas, mas não permite que os alunos discutam, a fala é unicamente dela. Depois, pede para que os alunos respondam a questão individualmente e entreguem em folhas separadas para correção. Como não há discussão entre os alunos e a professora, essas questões serão analisadas na seção "Questões Escritas".

A quinta questão também foi classificada como $\mathrm{P} 2$, pois os alunos deveriam comparar a temperatura de fusão e de solidificação da naftalina: "A temperatura de fusão da naftalina é próxima à sua temperatura de solidificação? Verifique os valores que você obteve. Pode-se admitir que essas temperaturas sejam iguais?"

A professora faz uma breve discussão com os alunos relembrando os valores obtidos para as temperaturas de fusão e solidificação e pede para que novamente respondam por escrito. Pelo fato de a professora não ter realizado uma discussão 
mais aprofundada desta questão com os alunos durante a aula, as repostas dos alunos serão analisadas na seção "Questões Escritas". As questões seis e sete também foram brevemente comentadas pela professora e foi pedido para que os alunos também respondessem por escrito:

6. "Qual é o ponto de fusão da naftalina?"

7. "A parafina apresenta um único valor para o ponto de fusão? Explique sua resposta".

A questão 6 foi classificada no nível P3 de habilidade cognitiva, pois exige que o aluno realize uma análise mais detalhada sobre os valores obtidos no experimento e sobre o gráfico construído, uma vez que a naftalina apresenta uma temperatura de fusão e solidificação constante em um determinando tempo, exigindo que os alunos avaliem as condições do problema. Deve-se considerar que, pode parecer mais sensato para o aluno, relacionar, por exemplo, que a fusão de um material ocorre com o aumento da temperatura em função do tempo, do que em uma faixa constante de temperatura. Assim, a questão 7 foi classificada como P2, por exigir dos alunos contrastar e aplicar leis para a solução do problema. A análise das respostas dos alunos encontra-se na seção "Questões Escritas".

Seguindo a seqüência do material, a professora propõe a discussão das questões para conclusões. Porém, ela discute com os alunos em sala apenas as questões 1 e 2. Quanto às outras questões, ela lê o enunciado e pede para que os alunos respondam Sim ou Não e justifiquem suas respostas por escrito. A análise da discussão das duas primeiras questões evidenciou um momento de manifestação de habilidades cognitivas de alta ordem, pois exige que os alunos analisem as variáveis do problema para elaborar hipóteses e propor soluções. Assim, as duas questões foram classificadas no nível P3:

1. "Considerando que a quantidade de naftalina variou a cada grupo, você pode dizer que o ponto de fusão depende da quantidade de material?"

2. "Considerando que cada grupo de alunos utilizou naftalina de diferentes fabricantes, você pode dizer que o ponto de fusão depende da procedência da amostra?"

Durante a discussão dessas duas questões, evidencia-se a proposição de 5 questões $\mathrm{P} 3$ e 3 questões $\mathrm{P} 1$ pela professora, e 6 respostas N2 e duas seqüências 
de respostas manifestadas pelos alunos com ao auxílio da professora, classificadas como N4:

\begin{tabular}{|c|c|c|}
\hline Tempo & Discurso & Análise \\
\hline $46: 54$ & $\begin{array}{l}\text { P:Um...considerando que a quantidade de naftalina variou a cada } \\
\text { grupo...você pode dizer que o ponto de fusão depende da } \\
\text { quantidade de material? }\end{array}$ & P3 \\
\hline 47:03 & Al1: Coloquei sim & \\
\hline 47:03 & Al: Não & \\
\hline 47:15 & $\begin{array}{l}\text { P:É isso que vocês têm que observar...se um grupo trabalhou com } \\
\text { cem gramas de naftalina e outro grupo trabalhou com cinqüenta } \\
\text { gramas de naftalina }\end{array}$ & \\
\hline 47:15 & Al: Vai demorar mais (a) & \\
\hline 47:20 & P:Vai demorar mais mas e o ponto de fusão vai ser diferente? & P3 \\
\hline $47: 22$ & Al: Não (b) & \\
\hline 47:27 & P:O ponto de fusão vai ser diferente ou vai ser o mesmo? & \\
\hline 47:31 & Al1:O mesmo só que vai demorar mais (c) & $(\mathrm{N} 4 \mathrm{a}, \mathrm{b}, \mathrm{c})$ \\
\hline $47: 38$ & $\begin{array}{l}\text { P:Então vai demorar mais e o que vai variar em relação à } \\
\text { quantidade? }\end{array}$ & P3 \\
\hline 47:41 & Al: Tempo (d) & \\
\hline 47:46 & P:Mas e o ponto de fusão? & \\
\hline 47:49 & Al 1:É o mesmo (e) & \\
\hline 47:52 & P:Por que o mesmo? & \\
\hline 47:54 & Al: Por que não muda (f) & \\
\hline 47:55 & P:Por que não muda? & \\
\hline 47:56 & Al:Independente da quantidade (g) & $\mathrm{N} 4(\mathrm{e}, \mathrm{f}, \mathrm{g}, \mathrm{h})$ \\
\hline
\end{tabular}

É importante relatar que o papel da professora é de suma importância para conduzir os alunos na elaboração de suas respostas orais ou escritas, pois observou-se que, para as questões nas quais a professora não realizou uma discussão em sala, os alunos não apresentaram respostas escritas condizentes com os conceitos exigidos ou, até mesmo, deixaram de respondê-las.

As respostas escritas dos alunos para essas duas questões e também para as outras questões propostas no material sobre as conclusões, encontram-se na seção "Questões Escritas".

\section{Quarta aula - Questões para discussão}

No início da aula, a professora pede para os alunos formarem grupos para que cada um responda a uma questão para discussão, contidas no material. Após aproximadamente trinta e quatro minutos, a discussão com toda a sala se inicia.

A primeira questão proposta é: "O ponto e fusão da glicerina é $17^{\circ} \mathrm{C}$. Qual é o estado físico desta substância no dia de hoje?" 
Esta questão foi classificada como P3 por exigir que os alunos avaliem as condições e proponham suas hipóteses para sua resolução.

A professora pede para os alunos participantes do grupo que respondeu à essa questão, esboçarem um gráfico no quadro, indicando a temperatura de fusão da glicerina e a temperatura ambiente, e seus respectivos estados físicos. Durante a discussão e a construção do gráfico, a professora propõe algumas questões para conduzir os alunos à resposta para o problema; dessas, 5 foram classificadas como P1 pois exigiam somente que os alunos lembrassem dos estados físicos; 3 foram classificadas como P2, pois os alunos precisavam comparar ou aplicar conceitos; e duas foram classificadas como P3, por exigir que os alunos avaliassem condições. $\mathrm{O}$ número total de questões propostas pela professora e o nível de exigência cognitiva estão na figura 8.

O episódio abaixo exemplifica as questões propostas e as respostas dos alunos, classificadas em seus níveis de habilidades cognitivas:

\begin{tabular}{|c|c|c|}
\hline Tempo & Discurso & Análise \\
\hline $38: 20$ & $\begin{array}{l}\text { P:Digamos que hoje esteja vinte e um graus...é maior ou menor } \\
\text { que dezessete? }\end{array}$ & P2 \\
\hline $38: 25$ & Al1: Maior & N2 \\
\hline $38: 43$ & $\begin{array}{l}\text { P:Se é maior e está em menos dezessete }\left(\left(-17^{\circ} \mathrm{C}\right)\right) \text { em que estado } \\
\text { físico este material está? } \\
\text { P:Qual o estado físico exatamente ali no ponto de fusão? } \\
\text { P:Está ocorrendo a fusão...tenho só sólido? }\end{array}$ & P2 \\
\hline 38:54 & Al 3: Sólido e liquido & N3 \\
\hline 39:09 & $\begin{array}{l}\text { P:Se estiver vinte e um graus como está hoje...vinte e um graus é } \\
\text { maior que dezessete } \\
\text { P:Como ficaria o gráfico ali...subiria mais um pouquinho...vai } \\
\text { subindo mais um pouquinho } \\
\text { P:Qual o estado físico ali quando já está subindo? }\end{array}$ & P2 \\
\hline $39: 22$ & Al1: Liquido & $\mathrm{N} 2$ \\
\hline 39:27 & $\begin{array}{l}\text { P:Líquido ali onde esta vinte e um graus daí para cima estado } \\
\text { líquido } \\
\text { P:Por que daí para cima é tudo líquido pessoal? } \\
\text { P:Líquido...ali onde é vinte e um graus já é liquido }\end{array}$ & \\
\hline $39: 43$ & Al: Aqui? & \\
\hline $39: 47$ & $\begin{array}{l}\text { P:A partir daí para cima é tudo líquido } \\
\text { P:Por que daí para cima é tudo liquido pessoal? }\end{array}$ & P3 \\
\hline 39:54 & Al 1: Passou do dezessete aí é gasoso & N1 \\
\hline 40:00 & P:Não aí no dezessete estava sólido mais líquido & \\
\hline $40: 02$ & Al1: $\dot{E}$ & \\
\hline $40: 05$ & P:E acima do dezessete & \\
\hline $40: 08$ & Al: Tudo líquido & N3 \\
\hline
\end{tabular}


A segunda questão foi: "O ponto de fusão da amônia é $-77^{\circ} \mathrm{C}$. Num determinado ponto do Pólo Norte, onde a temperatura fosse $-80 \stackrel{\circ}{\mathrm{C}}$ em que estado físico você encontraria esta substância?"

Esta questão também foi classificada como P3. A professora também pede para os alunos esboçarem o gráfico no quadro. Evidencia-se grande dificuldade da aluna em organizar os eixos e decidir se o gráfico é crescente ou decrescente, mas com o auxílio da professora a aluna começa a compreender porque o gráfico é crescente e não decrescente. Nesta questão a professora também conduz os alunos à resposta do problema. Foram elaboradas 7 questões pela professora, duas classificadas como P1 e duas como P2, as outras questões relacionadas diretamente ao problema foram classificadas como P3.

O episódio a seguir mostra uma das alunas formulando uma resposta que exibe habilidades cognitivas de alta ordem (N4), pois a aluna analisa as variáveis e propõe a solução para o problema:

\begin{tabular}{|l|l|l|}
\hline \multicolumn{1}{|c|}{ Tempo } & \multicolumn{1}{|c|}{ Discurso } & \multicolumn{1}{|c|}{ Análise } \\
\hline $45: 19$ & $\begin{array}{l}\text { P:O ponto de fusão da amônia é }-77^{\circ} \mathrm{C} . . . n u m \text { determinado ponto } \\
\text { do Pólo Norte...onde a temperatura fosse }-80^{\circ} \mathrm{C} \text { em que estado } \\
\text { físico você encontraria esta substância? }\end{array}$ & P3 \\
\hline $45: 28$ & Al: Sólido & N3 \\
\hline $45: 31$ & P:Por que é sólido & P3 \\
\hline $45: 36$ & Al $6:$ Porque menos oitenta graus é menor que setenta e sete & N4 \\
\hline $45: 40$ & P:Menos oitenta graus é menor que menos setenta e sete? & P2 \\
\hline $45: 43$ & Al: Menor & N3 \\
\hline $45: 48$ & $\begin{array}{l}\text { P:Se eu fosse marcar ai no gráfico onde ficaria o menos oitenta } \\
\text {...acima ou abaixo setenta e sete }\end{array}$ & P2 \\
\hline $45: 54$ & Al5: Abaixo & N3 \\
\hline $46: 02$ & $\begin{array}{l}\text { P:Porque menos oitenta é menor que menos setenta e sete } \\
\text { Qual o estado físico do material em menos oitenta graus? }\end{array}$ & P3 \\
\hline $46: 18$ & Al: Sólido & N3 \\
\hline
\end{tabular}

Percebe-se que nas questões para discussão, o número de questões propostas P3 é mais elevado pois o grau de exigência é maior, ou seja, não basta somente relembrar uma informação ou comparar dados para solucionar o problema, os alunos precisam analisar o gráfico, as variáveis do problema e propor as suas soluções. As respostas escritas dos alunos referentes a essas duas questões também foram analisadas na seção "Questões Escritas", pois são questões que exigem maior habilidade de síntese, demandando maior esforço cognitivo pelos alunos. 
A professora, depois, faz a discussão das outras três questões propostas no material, porém esta discussão foi breve e não será considerada para a análise, uma vez que se tratam de questões não direcionadas ao problema inicial de investigação e não contribuiriam para o foco da pesquisa. A professora deixa o tempo livre para os alunos responderem às questões em sala e entregarem.

As figuras a seguir mostram o número total de questões propostas pela professora relacionados ao nível cognitivo exigido na terceira aula e na quarta aula (figura 8) e também o nível cognitivo das respostas elaboradas pelos alunos (figura 9):

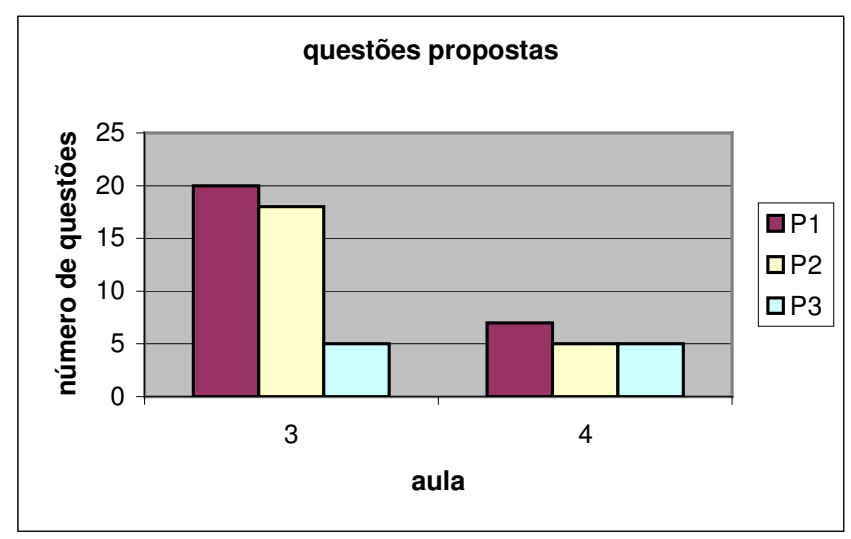

Figura 8. Nível de cognição das questões propostas pelo professor na $3^{\mathrm{a}}$ aula e na $4^{\mathrm{a}}$ aula

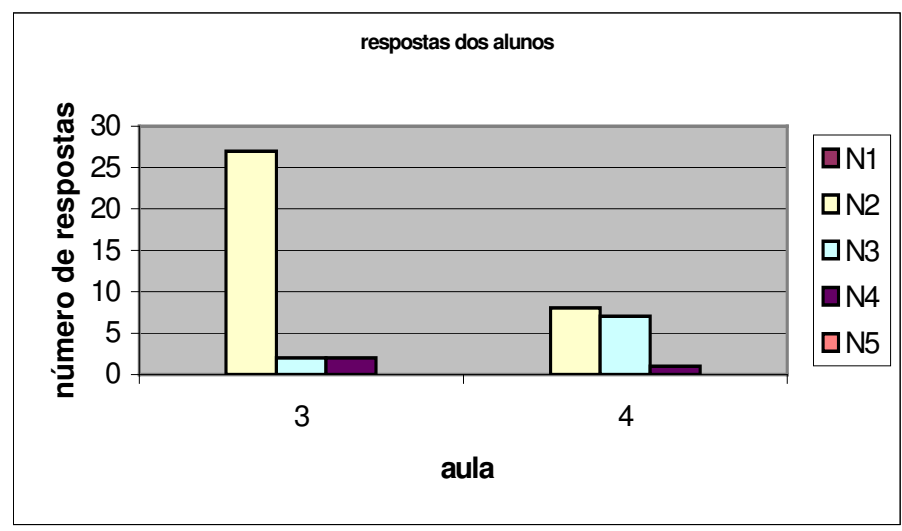

Figura 9. Nível de cognição das respostas dos alunos às questões apresentadas na $3^{\mathrm{a}}$ aula e na $4^{\mathrm{a}}$ aula

Observa-se que, durante a terceira aula, a professora propõe um número elevado de questões, porém a grande maioria das questões foi classificada nos níveis $\mathrm{P} 1$ e P2, ou seja, questões que exigem que os alunos apenas recordem 
informações ou apliquem leis para a sua resolução. Verifica-se que as respostas dos alunos são condizentes com as questões propostas pela professora, ou seja, quase todas as respostas foram classificadas no nível $\mathrm{N} 2$, em que o aluno reconhece a situação problemática mas não estabelece processos de controle para a seleção das informações ou não justifica a sua resposta com os conceitos exigidos. Segundo Zohar (1998), em aulas nas quais o professor propõe muitas questões, a maioria delas exige, para sua resolução, habilidades cognitivas de baixa ordem. Ou seja, não importa o número de questões propostas, mas sim, a exigência cognitiva.

$\mathrm{Na}$ quarta aula, quando a professora propõe algumas questões para discussão, o número de questões propostas é menor, talvez porque grande parte do tempo da aula foi dedicado para os alunos resolverem as questões em grupo. Ao analisarmos as duas aulas, podemos concordar com os argumentos de Zohar (1998), pois o número de questões P3 é o mesmo nas duas aulas, independente do número de questões propostas.

É importante relatar que nenhuma resposta foi classificada como N1, o que indica que os alunos compreenderam o problema e o que deveria ser buscado.

Nenhuma resposta foi classificada como N5, pois em nenhuma das respostas evidenciou-se um raciocínio por parte dos alunos que exibisse a generalização do problema ou a abordagem do conceito em outras condições. Talvez também, porque a professora não proporcionou momentos ou questões que exigissem tais habilidades pelos alunos.

\subsubsection{Questões escritas}

\section{Questões para análise dos dados}

Após avaliar as respostas escritas dos alunos, concluiu-se que as questões 2 e 3 não seriam consideradas para análise escrita por serem questões que exigem uma resposta pontual que não precisam ser justificadas, respostas geralmente numéricas que dificultam a análise de habilidades cognitivas.

As outras questões, porém, permitem que os alunos justifiquem suas respostas devido à maneira como foram formuladas, uma vez que não se pergunta, por exemplo, "Qual é a temperatura", limitando o argumento do aluno a uma 
resposta simplesmente numérica, mas são questões mais abertas, ampliando a possibilidade do aluno poder justificar a sua resposta.

As análises das questões 4, 5 e 7 são apresentadas a seguir, com exemplos de algumas respostas dos alunos. No total, 27 alunos entregaram os trabalhos e exercícios para a professora, os quais foram fotocopiados pela pesquisadora (Anexo J); porém, dois destes alunos não entregaram todos os materiais e não foram considerados na análise.

A figura 10 mostra os níveis de habilidades cognitivas manifestadas pelos alunos ao responderem às questões por escrito. Nem sempre o número total de alunos representado nos gráficos será equivalente aos 25 alunos que entregaram os materiais, pois alguns alunos não responderam às respectivas questões.

Questão 4: "A naftalina apresenta um único valor para o ponto de solidificação ? E a parafina?"

P2

Nesta questão, a professora esperava que, ao analisarem os gráficos, os alunos concluíssem que a naftalina apresenta uma única temperatura para a fusão e solidificação, diferentemente da parafina, a qual a fusão e solidificação ocorrem em um intervalo de temperatura:

\begin{tabular}{|l|l|l|}
\hline \multicolumn{1}{|c|}{ Alunos } & \multicolumn{1}{|c|}{ Respostas } & \multicolumn{1}{|c|}{ Análise } \\
\hline $\begin{array}{l}\text { Aluno } 7 \\
\text { (investigou } \\
\text { naftalina) }\end{array}$ & Sim porque a solidificação tem um ponto único que é 50 ${ }^{\circ} \mathrm{C}$ & $\mathrm{N} 3$ \\
\hline $\begin{array}{l}\text { Aluno 14 } \\
\text { (investigou } \\
\text { parafina) }\end{array}$ & $\begin{array}{l}\text { Não, o valor pode alterar, depende da temperatura do } \\
\text { ambiente ou da mistura }\end{array}$ & $\mathrm{N} 2$ \\
\hline $\begin{array}{l}\text { Aluno 5 } \\
\text { (investigou } \\
\text { parafina) }\end{array}$ & $\begin{array}{l}\text { Sim a parafina apresenta um único ponto de fusão igual a a } \\
\text { naftalina }\end{array}$ & $\mathrm{N} 1$ \\
\hline $\begin{array}{l}\text { Aluno 12 } \\
\text { (investigou } \\
\text { naftalina) }\end{array}$ & $\begin{array}{l}\text { Sim a naftalina, que é constituída por uma única } \\
\text { substância, o naftaleno, apresenta uma única temperatura } \\
\text { de fusão e de solidificação. A parafina, que é uma mistura } \\
\text { de várias substâncias apresenta uma faixa de temperatura } \\
\text { onde ocorre a fusão e uma faixa de temperatura } \\
\text { correspondente à solidificação }\end{array}$ & $\mathrm{N}$ \\
\hline
\end{tabular}

Em geral, os alunos respondem à questão utilizando sim ou não, dependendo do experimento (parafina ou naftalina) mas não apresentam justificativas coerentes para as suas respostas. Assim, quando o aluno reconheceu o problema mas não selecionou as informações relevantes para a solução do problema, suas respostas 
foram classificadas como N2, conforme mostra o exemplo da resposta do aluno 14, ao responder corretamente que a parafina não apresenta uma única temperatura de solidificação, mas não avaliou as informações para justificar sua resposta.

Os alunos que responderam à questão identificando as varáveis e explicando a resolução do problema com os conceitos discutidos em sala, tiveram suas respostas classificadas no nível N3 de cognição. O aluno 7 apresenta um valor para a solidificação da naftalina não condizente com os valores físico-químicos conhecidos, entretanto o aluno compreendeu os significados conceituais propostos no problema. Esse valor para a solidificação da naftalina pode ser explicado pelas dificuldades encontradas pelos alunos na execução do experimento, conforme já foi mencionado.

Grande parte das respostas foi classificada no nível N1, pois muitos alunos não compreenderam o problema ou confundiram substância pura com mistura, definindo parafina como substância pura e naftalina como mistura de substâncias. Duas alunas respondem justificando com os conceitos exigidos (N3), porém suas respostas são muito parecidas com um texto que é apresentado no material para a aula seguinte, conforme mostra o exemplo da aluna 12. Como não se pode provar a hipótese de que as alunas tenham se baseado no texto para elaborar suas respostas, estas foram classificadas como N3. Seis alunos não responderam à questão. Dois alunos relacionam o fato de a temperatura de solidificação não ser constante devido à quantidade de material ou à temperatura ambiente, embora isto tenha sido tratado pela professora nas questões 1 e 2 para conclusões na terceira aula.

Questão 5: "A temperatura de fusão da naftalina é próxima à sua temperatura de solidificação? Verifique os valores que você obteve. Pode-se admitir que essas temperaturas sejam iguais?"

$P 2$

\begin{tabular}{|l|l|l|}
\hline \multicolumn{1}{|c|}{ Alunos } & \multicolumn{1}{|c|}{ Respostas } & \multicolumn{1}{|c|}{ Análise } \\
\hline Aluno 1 & $\begin{array}{l}\text { Sim, pois a temperatura de solidificação foi próxima à de } \\
\text { fusão }\end{array}$ & $\mathrm{N} 2$ \\
\hline Aluno 16 & Sim, elas são iguais & $\mathrm{N} 2$ \\
\hline Aluno 27 & $\begin{array}{l}\text { Não, pois quando ele estava aquecendo ele estava } \\
\text { derretendo, quando estava esfriando chegando no } 50{ }^{\circ} \mathrm{C} \\
\text { ficou sólido }\end{array}$ & $\mathrm{N}$ \\
\hline
\end{tabular}


Nessa questão, os alunos deveriam comparar as temperaturas de fusão e solidificação da naftalina, e considerar em suas respostas, caso tenha ocorrido, possíveis variações nas medidas, o que permitiria considerá-las iguais.

As respostas classificadas no nível cognitivo N2 são aquelas que evidenciaram que os alunos compreenderam o problema, mas não estabeleceram processos de controle para explicar as variações nas medidas de temperatura de fusão e solidificação, apenas respondiam repetindo o conteúdo da questão proposta.

O elevado número de questões classificadas como N1 pode estar relacionado ao fato de alguns grupos terem obtido medidas não condizentes para a fusão e solidificação da naftalina, uma vez que os gráficos apresentavam as características de uma mistura de substâncias, não condizentes com as amostras utilizadas, que eram de naftalina com alto grau de pureza. Alguns dos materiais analisados podem conter as respostas dos alunos antes ou depois de a professora ter realizado novamente o experimento, o que poderia permitir respostas com níveis cognitivos diferentes, entretanto, o conteúdo dos materiais não permite realizar tais inferências.

Nesta questão, três alunos não responderam e outras duas respostas apresentavam ambigüidade, sendo então desconsideradas. Foi observado também que o fato de a questão apresentar duas perguntas em uma dificultou sua análise, pois algumas vezes não se sabe se o Sim ou Não se refere à primeira ou à segunda questão.

\section{Questão 6: "Qual é o ponto de fusão da naftalina?"}

P2

As respostas dos alunos a essa questão não foram analisadas pois, conforme já mencionado, os alunos encontraram dificuldades durante a coleta de dados para investigarem as temperaturas de fusão e solidificação da naftalina. Assim, grande parte as respostas dos alunos a essa questão não condizem com o esperado para uma substância, pelo contrário, os alunos responderam considerando a naftalina como uma mistura de substâncias. Portanto esta questão não foi analisada.

Questão 7: "A parafina apresenta um único valor para o ponto de fusão? Explique sua resposta"

P2 


\begin{tabular}{|l|l|l|}
\hline \multicolumn{1}{|c|}{ Alunos } & \multicolumn{1}{|c|}{ Respostas } & \multicolumn{1}{c|}{ Análise } \\
\hline Aluno 2 & Não, porque é uma mistura de várias substâncias & N3 \\
\hline Aluno 6 & Sim, um único ponto de fusão & N1 \\
\hline Aluno 11 & Não porque são diferentes & N1 \\
\hline
\end{tabular}

Nesta questão, apenas três alunos responderam satisfatoriamente mencionando que o gráfico indica uma mistura de substâncias, identificando os processos de controle para a resolução do problema, sendo suas respostas classificadas no nível N3. Conforme evidencia a figura 10, 11 respostas foram classificadas como algorítmicas (N1), pois muitas vezes os alunos não compreenderam o problema e responderam à questão com argumentos não coerentes aos conceitos exigidos. Desperta a atenção o número de alunos que não responderam a esta questão, 11 deles deixaram em branco. O alto número de respostas $\mathrm{N} 1$ e em branco pode ser atribuído ao fato de grande parte dos alunos terem se agrupado com aqueles que haviam realizado o experimento da naftalina, pois conforme mencionado anteriormente, muitos alunos faltaram na execução do experimento e utilizaram os dados obtidos pelos alunos participantes da atividade experimental. Assim, a grande maioria dos alunos pode não ter conseguido argumentar sobre o gráfico da parafina. Dos vinte e cinco materiais fotocopiados para análise, apenas 7 são referentes à temperatura de fusão e solidificação da parafina.

Também, até esse momento, a professora não realizou uma comparação dos dois gráficos para que os alunos percebessem suas diferenças e investigassem os problemas propostos pelo experimento investigativo.

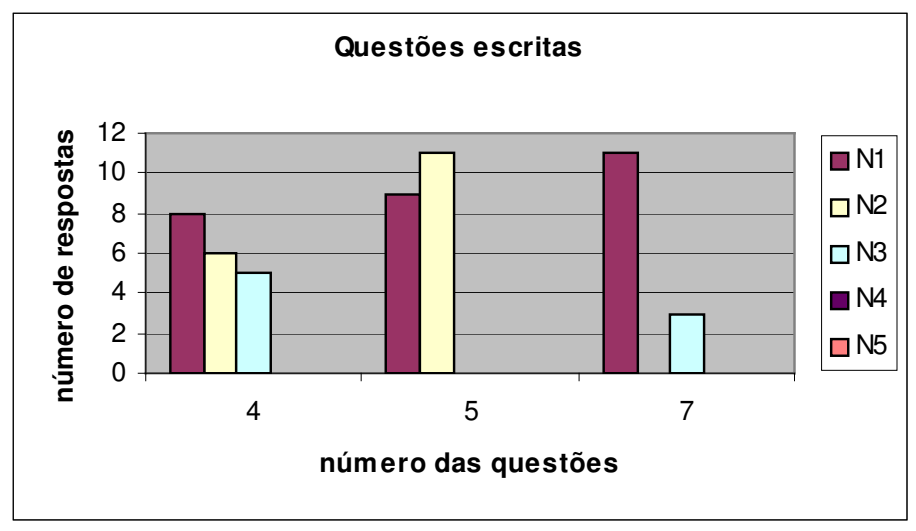

Figura 10. Nível cognitivo das respostas escritas dos alunos às questões 4,5 e 7 


\section{Questões para conclusões}

Questão1: "Considerando que a quantidade de naftalina variou a cada grupo, você pode dizer que o ponto de fusão depende da quantidade de material?"

P3

A análise das respostas dos alunos evidencia um número elevado de respostas $\mathrm{N} 1$; muitos alunos respondem somente SIM e outros justificam com idéias não condizentes com os conceitos em aula, evidenciando a não compreensão do problema; conforme mostra a resposta do aluno 24. Entretanto, 8 alunos responderam identificando os processos de controle para a solução, mas ainda sem analisar e selecionar as informações relevantes; alguns respondem reelaborando o próprio enunciado, sendo suas respostas classificadas no nível N3, conforme mostra o exemplo abaixo:

\begin{tabular}{|l|l|l|}
\hline \multicolumn{1}{|c|}{ Alunos } & \multicolumn{1}{|c|}{ Respostas } & \multicolumn{1}{|c|}{ Análise } \\
\hline Aluno 1 & Não, pois é o mesmo material, independe da quantidade & N3 \\
\hline Aluno & $\begin{array}{l}\text { Não depende da quantidade o ponto de fusão será o } \\
\text { mesmo }\end{array}$ & N3 \\
\hline Aluno 4 & $\begin{array}{l}\text { Sim, da quantidade e do tempo, porque no aquecimento , } \\
\text { quanto mais quantidade de naftalina mais demora para } \\
\text { aquecer }\end{array}$ & N1 \\
\hline Aluno 24 & Sim & N1 \\
\hline
\end{tabular}

É importante relatar que dois alunos relacionam a quantidade de material com o tempo, uma concepção também verificada nos alunos da escola $A$.

Outra consideração a ser feita se refere à comparação dos dados dos grupos que deveria ser realizada em sala mas não ocorreu. Talvez se a professora tivesse empregado mais tempo nessa discussão, os alunos poderiam ter compreendido com maior clareza a relação da temperatura de fusão com a quantidade de material.

Questão 2: "Considerando que cada grupo de alunos utilizou naftalina de diferentes fabricantes, você pode dizer que o ponto de fusão depende da procedência da amostra?"

P3

A professora, nesta questão, esperava que os alunos relacionassem a resposta com a substância naftaleno, ou seja, que por se tratar de uma substância a temperatura de fusão é independente da procedência. As respostas que exibiram esse raciocínio foram classificadas como N4, as respostas N3 se referem somente 
ao fato de se tratar do mesmo material. As respostas classificadas no nível N1 evidenciam que os alunos não compreenderam o problema.

\begin{tabular}{|l|l|l|}
\hline \multicolumn{1}{|c|}{ Alunos } & \multicolumn{1}{|c|}{ Respostas } & \multicolumn{1}{c|}{ Análise } \\
\hline Aluno 5 & Não porque o material será o mesmo & N3 \\
\hline Aluno 16 & Não porque todos são uma única substância, o naftaleno & N4 \\
\hline Aluno 9 & $\begin{array}{l}\text { Sim, porque para chegar a ser parafina, em cada fábrica a a } \\
\text { mistura pode receber diferentes quantidades de cada } \\
\text { ingrediente }\end{array}$ & N1 \\
\hline
\end{tabular}

A questão três não será analisada, pois durante as aulas a professora não discute com os alunos o que significa o termo constante física e, verificando o material dos alunos, a grande maioria responde somente SIM sem justificar suas respostas.

É importante destacar que a partir da terceira questão a professora não faz uma discussão mais aprofundada em sala de aula sobre os pontos principais da questão. Ela pede para que os alunos respondam Sim ou Não e justifiquem as suas respostas. Os minutos restantes da aula foram reservados para que os alunos respondessem às questões.

No total são propostas nove questões para que os alunos respondam, porém serão analisadas, além das questões 1 e 2, somente as questões 4, 5 e 6, as quais exigem que os alunos avaliem os dados de uma tabela para responder ao problema; as outras questões somente exigiam definições e não contribuiriam significativamente para os objetivos deste trabalho.

A tabela 4.8 se refere às questões 4,5 e 6 :

Tabela 4.8- Pontos de fusão e de solidificação de algumas substâncias à pressão normal

\begin{tabular}{|c|c|c|}
\hline Substância & Ponto de Fusão (o C) & Ponto de Solidificação (o C) \\
\hline Uréia & 135 & 135 \\
\hline Ferro & 1535 & 1535 \\
\hline Cloreto de Sódio & 801 & 801 \\
\hline Açúcar & 185 & 185 \\
\hline Água & 0 & 0 \\
\hline Alumínio & 660,2 & 660,2 \\
\hline Tolueno & -95 & -95 \\
\hline
\end{tabular}


Questão 4: "Analisando a tabela, para caracterizar uma substância é necessário determinar tanto o seu ponto de fusão como o ponto de solidificação? Explique sua resposta".

P2: Exige comparar os dados da tabela

\begin{tabular}{|l|l|l|}
\hline \multicolumn{1}{|c|}{ Alunos } & \multicolumn{1}{|c|}{ Respostas } & \multicolumn{1}{|c|}{ Análise } \\
\hline Aluno 1 & $\begin{array}{l}\text { Não, pois o ponto de fusão e de solidificação são } \\
\text { próximos }\end{array}$ & N3 \\
\hline Aluno 5 & $\begin{array}{l}\text { Sim, pois cada substância tem seus pontos de } \\
\text { fusão quanto de solidificação }\end{array}$ & N1 \\
\hline
\end{tabular}

É muito elevado o número de respostas classificadas como $\mathrm{N} 1$, pois os alunos não compreendem o problema e não avaliam os dados da tabela, ou seja, não verificam que os valores para a temperatura de fusão e de solidificação são os mesmos para uma substância. Isto pode ter acontecido pelo fato de os dados obtidos pelos alunos no experimento serem diferentes, ou seja, a temperatura de fusão obtida foi próxima e não igual à temperatura de solidificação, conforme evidencia a resposta do aluno 1

Questão 5: "O ponto de fusão é uma propriedade característica de uma substância? Explique sua resposta".

P3

\begin{tabular}{|l|l|l|}
\hline \multicolumn{1}{|c|}{ Alunos } & \multicolumn{1}{|c|}{ Respostas } & \multicolumn{1}{c|}{ Análise } \\
\hline Aluno 1 & Sim, pois é onde ele muda de forma física & $\mathrm{N} 2$ \\
\hline Aluno 10 & $\begin{array}{l}\text { Sim porque dependendo da substância o ponto } \\
\text { de fusão é diferente }\end{array}$ & $\mathrm{N} 4$ \\
\hline Aluno 21 & $\begin{array}{l}\text { Sim, pois não depende da quantidade, assim } \\
\text { facilita o estudo da sua origem }\end{array}$ & $\mathrm{N} 1$ \\
\hline
\end{tabular}

Esta questão exigia que os alunos avaliassem as condições propostas na tabela para generalizar, ou seja, determinar se a temperatura de fusão é característica de uma substância. Conforme mostra a figura 11, a maior parte das respostas foi classificada no nível $\mathrm{N} 1$, pois os alunos não compreenderam o problema; duas respostas foram classificadas no nível N2 de cognição, uma vez que os alunos reconhecem a situação problema mas não justificaram suas respostas identificando as variáveis do problema proposto. As respostas classificadas no nível $\mathrm{N} 4$ foram aquelas nas quais os alunos selecionaram as variáveis e as informações relevantes ao analisarem a tabela. 
Questão 6: "Você poderia, através do ponto de fusão, diferenciar várias substâncias da mesma cor?"

P3

\begin{tabular}{|l|l|l|}
\hline \multicolumn{1}{|c|}{ Alunos } & \multicolumn{1}{|c|}{ Respostas } & \multicolumn{1}{c|}{ Análise } \\
\hline Aluno 10 & Sim, provaremos através de seu ponto de fusão & $\mathrm{N} 3$ \\
\hline Aluno 7 & $\begin{array}{l}\text { Não, pois há substâncias que possuem pontos de } \\
\text { fusão muito próximos }\end{array}$ & $\mathrm{N} 4$ \\
\hline Aluno 22 & $\begin{array}{l}\text { Não, porque sendo da mesma cor, isso é quase } \\
\text { impossível }\end{array}$ & $\mathrm{N} 1$ \\
\hline
\end{tabular}

As questões 5 e 6 exibem um elevado número de repostas classificadas no nível N1, conforme mostra a figura 11. As respostas são geralmente sem sentido e o aluno não as relaciona com os conceitos desenvolvidos em sala. É interessante notar as respostas dos alunos 10 e 7 à questão 6 . O aluno 7 respondeu não, mas justifica sua resposta dizendo que outras substâncias podem ter a temperatura de fusão parecida, avaliando as variáveis que dificultariam a sua identificação. O aluno 10, por sua vez, apenas responde concordando com o enunciado, mas não elabora sua resposta dizendo que cada substância possui uma temperatura de fusão característica. Entretanto, a própria redação da questão parece contribuir para que o aluno responda automaticamente, uma vez que não pede para o aluno justificar. Talvez se a questão omitisse a temperatura de fusão como meio de identificar a substância e questionasse os alunos sobre "como" poderiam identificar diferentes substâncias de mesma cor, os alunos pudessem ter manifestado habilidades de alta ordem cognitiva.

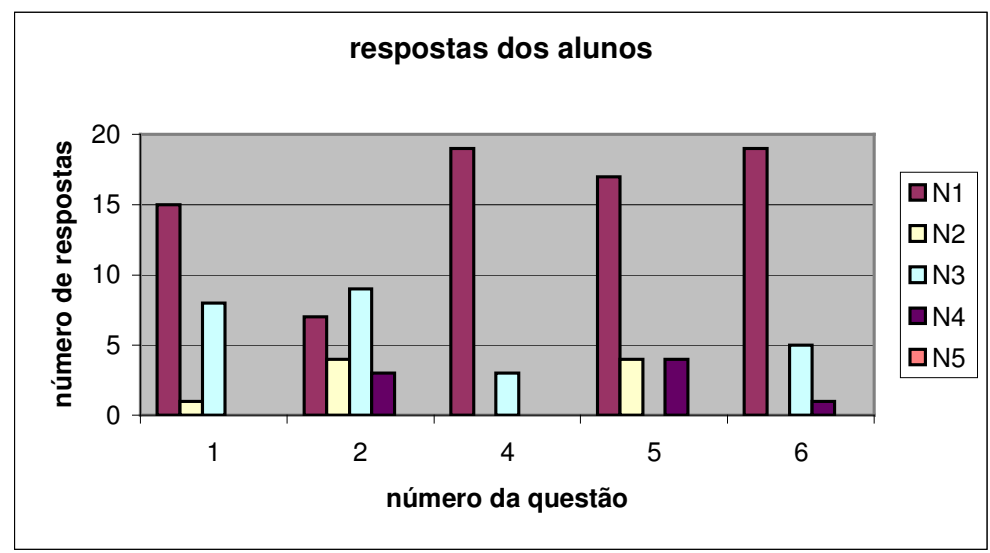

Figura 11. Nível cognitivo das respostas escritas dos alunos às questões 1,2,4,5 e 6 
Observa-se, nessa seqüência de aulas, um grande número de respostas classificadas nos níveis de baixa cognição, o que pode ser justificado pelo próprio desenvolvimento da aula investigativa. A atividade apresenta sutilmente as características de uma investigação, ou seja, a professora pouco problematiza os dados obtidos pelos alunos, não os faz analisar e hipotetizar. Ao contrário, sua conduta nos leva a presumir que há uma conclusão a ser alcançada, independente dos dados obtidos pelos alunos. A atividade investigativa parece perder, pelo menos em parte, seu potencial em desenvolver habilidades cognitivas de ordens superiores. Percebe-se o caráter investigativo nas etapas de coleta de dados, na construção de um gráfico, e na elaboração de algumas respostas escritas.

\section{Questões para discussão}

As duas questões que foram discutidas em classe também foram analisadas como questões escritas. As outras questões não foram analisadas por se tratar de questões que não condizem com os objetivos propostos no início da investigação e não contribuiriam significativamente para a análise; outro fator a ser mencionado é o de que as respostas dos alunos a essas três questões são serem muito parecidas umas com as outras e assemelham-se às respostas que a professora forneceu em sala de aula.

Questão 1: "O ponto e fusão da glicerina é $17^{\circ} \mathrm{C}$. Qual é o estado físico desta substância no dia de hoje?"

P3

\begin{tabular}{|l|l|l|}
\hline \multicolumn{1}{|c|}{ Alunos } & \multicolumn{1}{|c|}{ Respostas } & \multicolumn{1}{|c|}{ Análise } \\
\hline Aluno 16 & $\begin{array}{l}\text { Líquido sendo que a temperatura de hoje está em } \\
\text { torno de } 21^{\circ} \mathrm{C} \text { que é maior que } 17^{\circ} \mathrm{C} \text { que é seu } \\
\text { ponto de fusão }\end{array}$ & . \\
\hline Aluno 13 & $\begin{array}{l}\text { Acima de } 17^{\circ} \mathrm{C} \text { é o liquido e o de hoje o estado } \\
\text { seria sólido }\end{array}$ & $\mathrm{N} 1$ \\
\hline
\end{tabular}

Questão 2: "O ponto de fusão da amônia é $-77^{\circ} \mathrm{C}$. Num determinado ponto do Pólo Norte, onde a temperatura fosse $-80^{\circ} \mathrm{C}$ em que estado físico você encontraria esta substância?"

P3 


\begin{tabular}{|l|l|l|}
\hline \multicolumn{1}{|c|}{ Alunos } & \multicolumn{1}{|c|}{ Respostas } & \multicolumn{1}{c|}{ Análise } \\
\hline Aluno 5 & $\begin{array}{l}\text { Amônia estaria sólida porque a temperatura do } \\
\text { Pólo Norte é menor do que a temperatura do } \\
\text { ponto de fusão da amônia }\end{array}$ & $\mathrm{N} 2$ \\
\hline Aluno 15 & No estado sólido & . \\
\hline
\end{tabular}

Observa-se pela figura 12, que um grande número de alunos manifestaram em suas respostas habilidades cognitivas referentes ao nível $\mathrm{N} 4$, ou seja, habilidades cognitivas de alta ordem, uma vez que analisaram as variáveis do problema e propuseram hipóteses para sua solução. A resolução dessas questões em grupo pode ter contribuído para que os alunos propusessem suas idéias e discutissem com os pares, respondendo a questão com argumentos condizentes com os conceitos aprendidos. É importante verificar que essas respostas condizem com o tipo de pergunta proposta pela professora, pois essas questões exigiam que os alunos fizessem inferências e avaliassem as condições para a sua resolução.

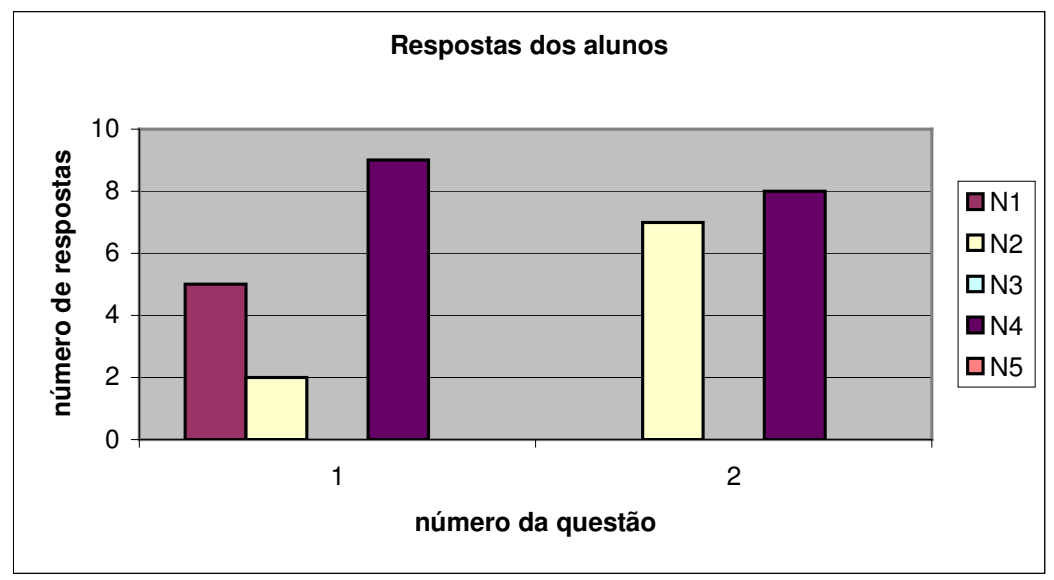

Figura 12. Nível cognitivo das respostas escritas dos alunos às questões 1 e 2

Na questão 1 evidenciam-se cinco respostas classificadas no nível N1 e na questão dois nenhuma. Com relação à questão dois, o número de respostas N2 é maior que na questão 1. As duas questões são parecidas, mas a classificação das respostas dos alunos com relação aos níveis $\mathrm{N} 1$ e N2 é diferente, talvez porque nessas questões para discussão a professora tenha separado os alunos em grupos para que cada um deles respondesse a uma questão. Deste modo, muitas respostas se assemelham; assim, se um aluno do grupo respondeu com habilidades cognitivas do nível $\mathrm{N} 1$ e um colega apenas a copiou, sua resposta também foi classificada como N1. Também, é importante relatar que dos vinte e cinco materiais fotocopiados 
para análise, nove não apresentavam respostas para a questão 1 e dez não apresentavam respostas para a questão 2, talvez porque a professora havia pedido para cada grupo responder a uma questão de discussão, entretanto, todos os integrantes de todos os grupos deveriam responder por escrito as cinco questões, porém, nem todos os alunos acataram ao seu pedido e entregaram somente a questão respondida pelo grupo.

Nenhuma resposta foi classificada no nível N3, pois as respostas exibiam ou habilidades do nível N2 na qual os alunos reconhecem a situação mas não justificam suas respostas, ou então, já manifestam habilidades cognitivas de alta ordem como elaboração de hipóteses e análise das variáveis. Nenhuma encontrava-se entre os dois níveis, baixo e alto.

Talvez, o fato de a professora ter discutido essas questões em sala de aula e mediado as idéias dos alunos, possa ter contribuído para um momento significativo na aprendizagem, uma vez que os alunos mantiveram certos raciocínios elaborados naquele momento; os quais podem ser evidenciados em suas respostas escritas. Os alunos precisaram sintetizar e argumentar sobre as idéias discutidas em sala de aula para elaborar suas respostas por escrito manifestando habilidades de alta ordem cognitiva por meio de um maior esforço cognitivo.

\subsubsection{Considerações sobre a atividade experimental investigativa: T.F.}

A atividade proposta no material utilizado pela professora da escola B apresenta as características de uma atividade experimental investigativa, pois a atividade é iniciada com uma questão problema e exige o engajamento dos alunos na investigação para sua solução. A atividade questionava os alunos sobre a possibilidade de se utilizar a temperatura de fusão para identificar um material. Para isso os alunos precisavam executar um experimento para testar esta hipótese através da análise de dados e de suas conclusões.

Porém, observa-se que durante as aulas a professora não propõe esse problema para os alunos. Ela inicia a primeira aula com a execução dos experimentos e depois, na segunda aula, auxilia os alunos na construção dos gráficos. Ainda, durante a terceira e quarta aulas, a professora não relaciona com os alunos, os dados obtidos e a questão problema. 
Também não fica evidenciado um momento de formulação de hipóteses para a solução do problema, o que poderia ter contribuído para a elaboração e desenvolvimento de raciocínios de alta ordem.

Durante a discussão das questões, a professora em alguns momentos, não permite que os alunos manifestem suas idéias, o que contribuiria para a percepção de idéias prévias manifestadas por eles.

No final da seqüência de aulas para a atividade que conceitua temperatura de fusão, a professora não realiza um fechamento, uma discussão com a sala para que os alunos compreendam o por quê e para quê realizaram o experimento. Por mais que a análise dos dados evidencie a participação dos alunos e manifestação de habilidades cognitivas de alta ordem, esta atividade poderia ter contribuído muito mais significativamente para aprendizagem dos alunos.

Porém, é importante relatar que durante a terceira e quarta aulas, quando a professora propõe as questões para resolução, poucos alunos participam da discussão e isto pode ter contribuído para que outras questões e discussões mais elaboradas não acontecessem.

A professora considera a sua postura construtivista, mas em alguns momentos ainda se observam atitudes tradicionais, como quando não oferece tempo para que o aluno pense sobre a questão proposta ou ao não fazer uma síntese do que foi desenvolvido.

Em conversas informais, a professora dizia que algumas vezes ainda achava suas aulas um pouco tradicionais. Pode-se considerar que esta professora ainda se encontra em transição, pois o construtivismo não é um método ou uma técnica, o construtivismo é algo complexo e está em constante processo de construção (Moraes, 2003). Dessa forma, podemos considerar que a professora está se desprendendo de algumas crenças ontológicas e epistemológicas que ainda fazem parte de sua conduta em sala de aula. Mas também devemos considerar alguns fatores que fazem com que suas aulas sejam consideradas construtivistas, como por exemplo, a mediação junto aos alunos, pois ela procura possibilitar que estes avancem à procura de novos conhecimentos. O diálogo também é uma das características a ser mencionada, pois, mesmo que em alguns momentos ela não tenha fomentado a discussão na sala, quando o aluno pede a palavra ela sempre permite que este exponha suas idéias e algumas vezes as contrasta e propõe novas questões. 
Uma outra característica de extrema importância que se deve citar é a constante reflexão que a professora faz de sua prática, quando questiona se sua postura foi a correta ou se poderia ter agido de outra maneira.

As condições oferecidas pela escola também podem ter contribuído para esses resultados, uma vez que a própria professora tinha de preparar os materiais e reagentes para os experimentos e não contava com o apoio total da direção para a realização dessas atividades no laboratório.

Conforme já foi relatado, a pesquisadora não pôde coletar os dados do conceito que seria desenvolvido posteriormente, pois alguns alunos estavam insatisfeitos com a presença da câmera em sala. Assim, para não prejudicar as aulas da professora e a própria pesquisa, entrou-se em comum acordo que as aulas só seriam registradas até o término do conceito de temperatura de fusão. A presença da câmera e de uma pessoa diferente do contexto de sala de aula podem ter contribuído para a pouca participação dos alunos nas discussões e conseqüentemente para a baixa manifestação de habilidades cognitivas de alta ordem.

$\mathrm{Na}$ análise das questões escritas observa-se um elevado número de questões N1, nas quais o aluno ainda não compreende o problema. Também é importante relatar o alto número de alunos que não responderam às questões, o que contribuiu para alguns resultados negativos. Isto pode indicar que os alunos não estavam engajados cognitivamente, e talvez, afetivamente, na realização da atividade.

Pode-se considerar também, novamente, o baixo número de respostas de alta ordem cognitiva devido à exigência do pesquisador ao elaborar suas categorias e as exigências cognitivas que as definem.

Observa-se, ainda, que os níveis cognitivos manifestados pelos alunos condizem com as questões propostas pela professora. Porém, quando se trata das questões escritas, o elevado número de respostas classificadas como N1 não corrobora esta afirmação. Esse elevado número pode estar relacionado com o alto grau de exigência cognitiva que a escrita exige, e muitos alunos poderiam não estar acostumados a expressar suas idéias de maneira mais estruturada conforme exige uma resposta escrita. 


\section{Considerações finais}

A presente pesquisa investigou as habilidades cognitivas manifestadas por estudantes do ensino médio de química em atividades experimentais investigativas. Os resultados mostraram que a utilização dessa estratégia contribui para a manifestação de habilidades cognitivas de alta ordem nos alunos. Entretanto, ao analisar as quatro seqüências de aulas, com diferentes públicos-alvo, algumas considerações podem ser inferidas. É importante ressaltar que a pesquisa não tinha como objetivo comparar os resultados das duas escolas investigadas, mas sim discutir as conclusões obtidas sobre estas, a fim de contribuir para uma reflexão sobre as potencialidades e dificuldades encontradas ao se propor e executar atividades desta natureza, com a finalidade de alcançar resultados positivos referente à aprendizagem dos alunos.

Elaborar e executar atividades experimentais investigativas não é um processo simples, exige que, além do aluno, o professor também esteja engajado na sua realização. Ao lado de dominar o conteúdo a ser desenvolvido, o professor precisa de tempo e cautela para elaborar uma atividade experimental investigativa. Deve se atentar aos pontos frágeis que podem gerar ambigüidades ou dificuldades conceituais nos alunos, como por exemplo, o que foi verificado ao analisar o experimento realizado pela professora da escola $\mathrm{A}$ sobre o conceito de temperatura de ebulição, no qual alguns alunos parecem ter permanecido com dificuldades em compreender a importância da variável tempo nas medidas de temperatura, e também da influência da pressão sobre a temperatura de ebulição.

Também, o professor precisa ter flexibilidade em sala de aula para, se necessário, adaptar-se às circunstâncias do processo de aprendizagem em andamento e às necessidades dos alunos (MORAES, 2003). Assim, a conduta do professor em sala se torna um dos papéis mais importantes durante as atividades experimentais investigativas. $O$ professor precisa problematizar o conteúdo desenvolvido, dialogar e questionar os alunos, permitindo que estes exponham suas idéias e discutam com os pares.

Verificou-se certa discrepância na conduta das duas professoras investigadas. A professora da escola A problematizou os conteúdos e conduziu os alunos na proposição de suas hipóteses e na explanação de suas idéias nas duas seqüências de aulas, o que parece ter contribuído para melhores resultados com 
relação à manifestação de habilidades cognitivas de alta ordem. Entretanto, a professora da escola B não problematizou o assunto inicialmente com os alunos e também não planejou momentos para que os alunos propusessem suas hipóteses e questionassem os dados e resultados obtidos. Essa conduta parece ter contribuído para que a atividade tivesse, de certa forma, o seu caráter investigativo não plenamente explorado, o que pode ter colaborado para o baixo desempenho dos estudantes da escola B na manifestação de habilidades cognitivas de alta ordem.

Os alicerces conceituais dos professores são de suma importância para que estes tomem as decisões sobre o que e como irão fazer, a fim de que a atividade experimental investigativa esteja estruturada de forma a evitar dificuldades conceituais e manipulativas por parte dos alunos durante todo o processo investigativo, podendo perceber, assim, certos obstáculos manifestados pelos alunos no desenvolvimento de um conceito (LIMA, 2004).

Outra consideração a ser feita com relação à conduta do professor nestas atividades se refere ao nível cognitivo das questões propostas. Observou-se, tanto na escola $A$ como na escola $B$, que o nível cognitivo das respostas dos alunos estão relacionados com o nível cognitivo das questões propostas pelas professoras. Entretanto, observa-se que esta afirmação tem maior validade quando se tratam de respostas orais do que quando os alunos elaboram suas repostas por escrito. Devese considerar que a escrita exige maior esforço cognitivo do aluno para sintetizar suas idéias, e este pode não estar preparado para atingir tal nível cognitivo e conceitual sozinho, uma vez que não há a mediação da professora para auxiliá-lo na elaboração de repostas mais completas.

É importante, também, que o professor dê oportunidade para os alunos manifestarem suas idéias, a fim de não criar um ambiente de medo e desconfiança por parte dos alunos, para que estes exponham seus pensamentos ainda não fundamentados, podendo assim mediá-los e conduzi-los a argumentos mais completos. Assim, os alunos podem se engajar conceitualmente e afetivamente na atividade e manifestar habilidades cognitivas de alta ordem.

Muitas vezes, ao se pensar em atividades experimentais investigativas, coloca-se demasiada ênfase na ação e participação do aluno, entretanto, pode-se inferir que a conduta do professor é de suma importância para que a atividade se desenvolva de maneira significativa para a aprendizagem do aluno. Assim, pode-se concluir que a mediação do professor nas atividades experimentais investigativas 
tem, talvez, o principal papel para um bom desenvolvimento da atividade e para um bom resultado com relação à manifestação de habilidades de ordem superior pelos alunos.

Também, é importante relatar que o número de questões propostas pelo professor no pré e pós-laboratório não determina o nível cognitivo das repostas elaboradas pelos estudantes, ou seja, não é significativa a proposição de inúmeras questões, principalmente quando estas, na maioria, são de baixa cognição (ZOHAR, 1998).

Também, pode-se perceber diferenças com relação às duas atividades realizadas pela professora da escola A. A primeira se refere ao experimento investigativo densidade e a segunda ao também experimento investigativo, entretanto, em uma abordagem caracterizada como laboratório aberto. Em todas as aulas, foi observada a elaboração de respostas dos alunos classificadas no nível N3 (baixa ordem) e N4 (alta ordem), corroborando a premissa de que as atividades investigativas são promotoras de habilidades cognitivas de alta ordem. No experimento de temperatura de ebulição, no entanto, foram observados momentos nos quais os alunos manifestaram maior número de habilidades cognitivas de alta ordem, como na elaboração do procedimento experimental e análise dos dados, e em outras etapas, a manifestação de habilidades cognitivas de baixa ordem prevaleceu.

Pode-se considerar, também, que o pré-laboratório é importante para problematizar a atividade, discutir as idéias principais e propor momento para que os alunos pensem sobre o problema e proponham suas hipóteses. As discussões orais, realizadas durante o pré e o pós-laboratório, podem permitir que os estudantes façam conexões significativas entre o fenômeno observado e os dados e os conceitos desenvolvidos nas aulas. A discussão pré-laboratório pode focalizar a atenção dos alunos no que eles irão observar e por quê; o pós-laboratório pode ajudar os estudantes a pensar sobre os dados obtidos, como os analisar e como conectar esses dados com os conceitos estudados (NAKHLEH, POLLES, MALINA, 2002). Na atividade realizada pela professora B não houve um momento prélaboratório, a aula já se iniciou com a execução do experimento. Talvez, se a professora tivesse dado oportunidade para que os alunos expusessem suas idéias, os resultados para essa a atividade experimental investigativa poderiam ter sido 
mais significativos com relação à manifestação de habilidades cognitivas de alta ordem.

A escrita se mostrou uma ferramenta importante no processo de aprendizado dos alunos quando envolvidos em atividades desse tipo, principalmente na atividade da temperatura de ebulição, na qual os alunos tiveram de elaborar os planos experimentais, descrevendo os objetivos, procedimentos, previsões e conclusões. Além de contribuir para um momento de reflexão sobre o problema a ser investigado e a importância das variáveis em todo o processo de investigação, ao escrever, os alunos precisam sintetizar suas idéias de modo que outras pessoas possam compreendê-las. Também, pode-se considerar que os alunos podem se sentir mais autônomos e responsáveis por suas atitudes.

A habilidade da escrita não é muito desenvolvida na química, pois, muitas vezes, os professores dão maior ênfase em processos quantitativos em detrimento aos qualitativos (QUEIRÓZ, 2001). Assim, as atividades experimentais investigativas, principalmente o Laboratório Aberto, podem permitir que essas habilidades sejam desenvolvidas pelos alunos.

A atividade também parece motivar os alunos no entendimento dos conceitos químicos e também na interação com os pares. Os diálogos entre professor e alunos e aluno-aluno promovem uma importante oportunidade para ajudar os estudantes a aprender a pensar criticamente. O professor precisa demonstrar aos estudantes como conduzir a investigação, como por exemplo, questionar, coletar dados, analisar os resultados e formular explicações (LIZOTTE; MCNEILL; KRAJCIK, 2004), contribuindo para a manifestação de habilidades cognitivas pelos alunos.

A análise das atividades também revelou que pode ser dada ao aluno maior responsabilidade frente à aprendizagem. Em atividades desta natureza, os alunos parecem se sentir mais motivados e engajados no processo de aprendizagem. Talvez, pelo fato de se sentirem mais autônomos e mais responsáveis por suas ações e atitudes, percebendo que o seu papel é de extrema importância e que não dependem de uma resposta única dada pelo professor (ZULIANI, 2000).

A maioria das respostas dos alunos foi classificada no nível N3 de cognição, podendo-se considerar que alcançar o N4 não seja um processo simples para todos os alunos. Enquanto alguns já apresentam habilidades de elaboração de hipóteses e análise dos dados no início das aulas, outros parecem precisar de um maior tempo e ensino para abstrair os conceitos aprendidos e aplicá-los nas situações investigadas. 
Não foi observada manifestação de habilidades cognitivas do N5, nas quais os alunos generalizam o conhecimento, podendo extrapolar suas idéias para outras situações. Talvez, se as aulas fossem contextualizadas, essas habilidades fossem verificadas, uma vez que, ao propor situações problematizadoras envolvendo questões sociais, científicas e ambientais, os alunos pudessem ultrapassar os limites dos conceitos desenvolvidos em sala e exibirem a capacidade de generalização.

Observa-se, também, que algumas respostas classificadas no início das atividades experimentais como alta ordem, foram no final das atividades classificadas como baixa ordem, uma vez que no início da aula os alunos precisavam pensar sobre a variável e propor hipóteses e, no final, essas hipóteses se tornavam constatações, podendo-se considerar que o que era um problema no início se tornou um exercício no final, como por exemplo, a análise de variáveis realizadas pelos alunos no experimento de temperatura de ebulição ao propor o plano experimental (problema) e depois no pós-laboratório (exercício).

As categorias de análise elaboradas pela pesquisadora se mostraram eficazes para classificar as falas e as respostas escritas dos alunos, o que pode contribuir para outras pesquisas na área e também para uma reflexão pelos professores sobre o tipo e qualidade das questões que estão sendo propostas em suas atividades experimentais e em suas aulas em geral.

Pode-se considerar que, principalmente nas atividades realizadas na escola A, os alunos tiveram a oportunidade de formular suas hipóteses, realizar experiências, analisar os dados e tirar conclusões, processos estes que, se trabalhados juntamente com as conclusões, ponderações e explicações, representam importantes aspectos da investigação científica (CARVALHO et al., 1999).

Assim, planejar e executar atividades experimentais investigativas pode contribuir para o desenvolvimento e manifestação de habilidades cognitivas de ordem superiores nos alunos. Desta forma, a utilização de atividades desta natureza nas escolas se mostra de suma importância para o desenvolvimento cognitivo do aluno.

Por fim, pode-se considerar que se a atividades experimental investigativa for elaborada e executada pelo professor com o objetivo de proporcionar aos alunos todas as suas potencialidades, os alunos poderão se engajar efetivamente na 
atividade e manifestar habilidades cognitivas necessárias para a formação de um indivíduo crítico e reflexivo sobre suas atitudes e sobre as ações tomadas por outros. 


\section{Bibliografia}

ANDRÉ; M. E. D. A. Etnografia da prática escolar. $5^{a}$ ed. São Paulo: Papirus, 2000, $128 \mathrm{p}$.

ASTOLFI, J.P. A didática das ciências. $4^{a}$ ed. Campinas: Papirus, 1995, 132 p.

BARBERÁ, O.; VALDÉS, P. El trabajo práctico en la ensenãnza de las ciencias: una revisión. Enseñanza de las Ciencias, 14 (3), p. 365-379, 1996.

BASTOS, F. et al. Da necessidade de uma pluralidade de interpretações acerca do processo de ensino e aprendizagem em ciências: re-visitando os debates sobre Construtivismo. In: BASTOS et al. Pesquisa em ensino de Ciências: contribuições para a formação de professores. São Paulo. Escrituras Editoras, 2004, p.9- 55.

BOGDAN, R.C.; BIKLEN, S.K. Investigação qualitativa em educação: uma introdução à teoria e aos métodos. Tradução Maria João Alvarez. Portugal, Porto Editora, 1994, 355p.

BRASIL. Ministério da Educação. Secretaria de Educação Média e Tecnologia. Parâmetros Curriculares Nacionais: Ensino Médio - Ciência da Natureza Matemática e Suas Tecnologias / Ministério da Educação. Brasília: Ministério da Educação / Secretaria de Educação Média e Tecnológica, 1999.

CAAMANÕ, A. Trabajos prácticos investigativos em química em relación com el modelo atômico-molecular de la materia planificados mediante um diálogo estructurado entre professor y estudiantes. Educación Química, 16(1), p.10-19, 2005.

CARVALHO, A. M. P. et al. Termodinâmica: Um ensino por investigação. $1^{a}$. ed. São Paulo: Universidade de São Paulo - Faculdade de Educação, 1999. v. 1. 123 p.

CARVALHO, A. M. P. et al. A História da Ciência, a Psicogênese e a Resolução de Problemas na Construção do Conhecimento em Sala de Aula. Revista da Faculdade de Educação (USP), 19, (2), 245-256, 1993.

CARVALHO, A.M.P. Uma metodologia de pesquisa para estudar os processos de ensino e aprendizagem em salas de aula. IN: SANTOS, F.M.P.; GRECA. A pesquisa em ensino de Ciências no Brasil e suas metodologias. $1^{\text {a }}$. edição. ljuí; Editora Unijuí, 2006. p13-48.

CARVALHO, A. M. P. ; GIL-PÉREZ, D. Formação de professores de ciências: tendências e inovações. São Paulo: Cortez . Coleção questões da nossa época, 1995. $120 \mathrm{p}$. 
CAPECCHI, M.C.V.M; CARVALHO, A.M.P. Argumentação em uma aula de conhecimento físico com crianças na faixa de oito a dez anos. Investigações em Ensino de Ciências, 5 (3), p. 171-189, 2002.

DOMIN, D.S. A Review of Laboratory Instruction Styles. Journal of Chemical Education. 76 (4), p. 543-547, 1999a

A content analysis of general chemistry laboratory manuals for evidence os higher-order cognitive tasks. Journal of Chemical Education, 76 (1), p. 109-111, 1999b.

ECHEVERRÍA, M. P.P; POZO, J. I. Aprender a resolver problemas e resolver problemas para aprender. In: ECHEVERRÍA, M. P.P; POZO, J. I. A solução de problemas. Trad. Beatriz Affonso Neves. Porto Alegre: Artmed, 1998, p. 13-42.

FERNANDES, M.M; SILVA, M.H.S. O trabalho experimental de investigação: das expectativas dos alunos às potencialidades no desenvolvimento de competências. Revista Brasileira de Pesquisa em Educação em Ciências, 4 (1), p.45-58, 2004.

GABEL, D. L.; SHERWOOD, R. D.; ENOCHS, L. Problem-solving skills of high school chemistry student. Journal of Research in Science Teaching, 21, p.221233, 1984.

GARCIA BARROS, S; MARTINEZ LOSADA, M.C.; MONDELO ALONSO,M. EI Trabajo Práctico: Una Intervencion para La Formacion de Professores. Enseñanza de Las Ciências,13(2), p.203-209,1995.

GALIAZZI, M.C; et al. Objetivos das atividades experimentais no ensino médio:a pesquisa coletiva como modo de formação de professores de ciências. Ciência \& Educação, 7 (2), p. 249-263, 2001.

GIL-PÉREZ, D.; et al. A Necessária Renovação do Ensino das Ciências. São Paulo: Cortez Editora, 2005 p.263.

GIL-PÉREZ, D. New trends in Science Education. International Journal of Science Education, 18 (8), 899-901, 1996.

GIL-PÉREZ, D; VALDÉS CASTRO, P. La orientacion de Las Prácticas de Laboratório com Investigacion: Um Ejemplo llustrativo. Enseñanza de Las Ciências, 14(2), p.155-163, 1996.

GOLDFARB, A.M.F. Da alquimia a química: um estudo sobre a passagem do pensamento mágico-vitalista ao mecanismo. São Paulo, Editora Nova Stella: EDUSP, 1987, $279 \mathrm{p}$.

GONZÁLES, E.M. Que Hay de Renovar en Los Trabajos Prácticos? Ensenãnza de Las Ciências, 10(2), p.206-211, 1992.

HODSON, D. Teaching and Learning Chemistry in the Laboratory: A Critical Look at the Research. Educación Química, 16(1), p.30-38, 2005. 
Hacia um Enfoque más critico del Trabajo de laboratório. Enseñanza de Las Ciências, 12(3), p.299-313, 1994.

A critical look at practical work in school science. School Science Review, 71, p. 33-40, 1990.

Experimentos em Ciências e Ensino de Ciências. Educational Philosophy and Theory, 20, p. 53-66, 1988.

HOFSTEIN, A.; NAVON, O.; KIPNIS, Mira; MAMLOK-NAAMAN, R. Developing Students' Ability to Ask More and Better Questions Resulting from Inquiry-Type Chemistry Laboratories. Journal of Research in Science Teaching, 42 (7), p. 791 806, 2005.

HOFSTEIN, A.; LUNETTA, V. The laboratory in science education: foundations for twenty-first century. Science Education, 88, p.28- 54, 2004.

JENKINS, E.W. Construtivism in school science education: powerful model or the most danerous intellectual tendency? Science \& Education, 9, 599-610, 2000.

JOHNSTONE, H.A.; AL-SHUAILI, A. Learning in the Laboratory: Some Thoughts From The Literature. University Chemistry Education, 5, p.4 2-51, 2001.

LABURÚ, C. E. Problemas abertos e seus problemas no laboratório de física: uma alternativa dialética que passa pelo discurso multivocal e univocal. Investigação em Ensino de Ciências, 8(3), p.231-256, 2003.

LIMA, V.A.de. Atividades Experimentais no Ensino Médio - Reflexão de um Grupo de Professores a partir do Tema Eletroquímica. Dissertação de Mestrado. Programa de Pós Graduação em Ensino de Ciências. Universidade de São Paulo, São Paulo, 2004.

LIZOTTE, D. J., McNEILL, K. L.; KRAJCIK, J. Teacher practices that support students' construction of scientific explanations in middle school classrooms. In KAFAI, Y.; SANDOVAL, W; ENYEDY, N; NIXON; A.; HERRERA, F. (eds). Proceedings of the sixth international conference of the learning sciences. Mahwah, NJ: Lawrence - Erlbaum Associates, Inc., 2004, p. 310-317.

LOCATELLI, R.J. Uma análise do raciocínio utilizado pelos alunos ao resolverem problemas propostos nas atividades de conhecimento físico. Dissertação de Mestrado. Programa de Pós Graduação em Ensino de Ciências. Universidade de São Paulo, São Paulo, 2006.

MALAVER, M.; PUJOL, R.: MARTINEZ, A. Análisis de actividades y preguntas propuestas sobre el tema de la estructura de la materia en textos universitarios de Qumica General. Educacion Quimica, 16 (1) p. 93-98, 2005.

MARR, J.H. Justus von Liebig, 1803-1873. Parte 1: Vida, Personalidade, Pensamento. Química Nova, 29 (5), p. 1129-1137, 2006. 
MATHIAS, Simão. Cem anos de química no Brasil. Coleção da Revista de História, São Paulo, LXIII, 1975.

MATTHEWS, M. R. Science teaching. The role of history and philosophy of science. Philosophy of Education. New York: Routledge, 1994.

MORAES, R. Mergulhos discursivos: análise textual qualitativa entendida como processo integrado de aprender, comunicar e interferir em discursos. In: GALIAZZI, Maria do Carmo; FREITAS, José Vicente (Org.) Metodologias emergentes de pesquisa em educação ambiental. ljuí: Editora Unijuí, 2005, p.86-114.

É possível ser construtivista no ensino de Ciências? In: . MORAES, R. Construtivismo e Ensino de Ciências Reflexões Epistemológicas e Metodológicas. $2^{\mathrm{a}}$ ed. Porto Alegre: EDIPUCRS, 2003. p. 103-129.

O significado da experimentação numa abordagem construtivista: o caso do ensino de Ciências. In: BORGES, R.; MORAES, R. Educação em Ciências nas Séries Iniciais. Porto Alegre: Sagra-Luzatto, 1998, p. 29-45.

MORTIMER, E.F. Construtivismo, mudança conceitual e ensino de ciências: para onde vamos? Investigações em Ensino de Ciências, 1(1), p. 20-39, 1996.

NAKHLEH, M. B.; POLLES, J.; MALINA, E. Learning Chemistryin a Laboratory Environment. In: GILBERT, J.K. et al. (eds). Chemical Education: Towards Research-based Practice. Kluwer Academic Publishers. Netherlands, 2002 pag. 6994.

OGBORN, J. Constructivist Metaphors of Learning Science. Science \& Education, 6, p. 121-133, 1997.

OLIVEIRA. A.M.A.; CARVALHO, A.M.P. Escrevendo nas aulas de Ciências. IX Encontro Nacional de Pesquisa em Ensino de Física, 2004. Disponível em http://www.sbf1.sbfisica.org.br/eventos/epef/ix/atas/comunicacoes/co102-2.pdf. Acesso em 11/08/2008.

PRETI, D.F. (Coord.) Análise de textos orais. $4^{a}$ ed. São Paulo: Humanitas, 1999, $236 \mathrm{p}$.

PINTRICH, G.L.; MARX, R.W.; BOYLE, R.A. Beyound Cold Conceptal Change. The role of motivacional beliefs and classroom contextual factors in the process of conceptual change. Review of Educational Research, 63 (2), p. 167-199,1993.

QUEIRÓZ, S.L. A linguagem escrita nos cursos de graduação em química. Química Nova, 24 (1), 144-146, 2001.

RIVARD, L.P.; STRAW, S.B. The effect of talk and writing on learning science, an exploratory study. Science Education, 84(5), p. 566-593, 2000. 
ROSITO, B.A. O ensino de Ciências e a experimentação. In: MORAES, R. Construtivismo e Ensino de Ciências Reflexões Epistemológicas e Metodológicas. $2^{\mathrm{a}}$ ed. Porto Alegre: EDIPUCRS, 2003. p. 195-208.

SANTOS, G.R: QUEIRÓZ, S.L;. Sá, L.P. A linguagem escrita nos cursos de graduação em química. Química Nova, 29 (5), 1121-1128 2006.

SCHNETZLER, R.P; ARAGÃO, R.M. Importância, sentido e contribuições para o ensino de química. Química Nova na Escola. São Paulo, n.1, p. 27-31,1995.

SHEPARDSON, D.P.; PIZZINI, E.L., Questioning levels of Junior high school science textbook and their implications for learning textual information. Science Education, 75 (6), 673-688, 1991.

SHEPPARD, K.; HOROWITZ, G. From Justus von Liebig to Charles W. Eliot: The establishment of laboratory work in U.S. Schools and Colleges. Journal of Chemical Education, 83 (4), p. 565-570, 2006.

SHILAND, Thomas W. Construtivismo:Implicações para o Trabalho de Laboratório. Journal of Chemical Education, 76 (1), p.107-109, 1999.

SICCA, N.A.L. A experimentação no ensino de Química - 20 Grau. Dissertação de Mestrado. Faculdade de Educação. Universidade Estadual de Campinas, Campinas, 1990.

STAMOVLASIS, D.; TSAPARLIS, G; KAMILATOS, C; PAPAOIKONOMOU, D; ZAROTIADOU, E. Conceptual understanding versus algorithmic problem solving: Further evidence from a national chemistry examination. Chemistry Education Research and Pratice, 6 (2), p. 104-118, 2005.

TAMIR, P. How are the laboratories used? Journal of Research in Science Teaching, 14 (4), p. 311-316, 1977.

TEIXEIRA,O.P.B. Desenvolvimento do conceito de calor e temperatura: a mudança conceitual e o ensino construtivista. Tese de doutorado. Faculdade de Educação. USP, São Paulo,1992.

VILLANI, A. ; PACCA, J.L.A. Construtivismo, Conhecimento Científico e Habilidade Didática no Ensino de Ciências. Revista da Faculdade de Educação da USP, 23 p.196-214, 1997.

WATSON, R.; PRIETO, T.; DILLION, J. S. "The Effect of Practical Work on Students Understanding of Combustion". Journal of Research in Science Teaching. 32 (5), p. 487-502, 1995.

YARDEN, A.; BRILL, G.; FALK, H. Primary literature as a basis for a high-school biology curriculum. Journal of Biological Education, 35, 190-195, 2001.

ZANON, Lenir B.; SILVA, Lenice H. A. "A Experimentação no Ensino de Ciências". In: Roseli P. Schnetzler e Rosália M. R. Aragão (Org.). Ensino de Ciências:

fundamentos e abordagens. Campinas: CAPES / UNIMEP, 2000, p. 120-153. 
ZYLBERSTAJN, A. Resolução de Problemas, uma perspectiva Kuhniana. Atas do VI Encontro de Pesquisa em Ensino de Física (CD Rom), Florianópolis, 1998.

ZOHAR, A. Assessing the cognitive demands required of students in class discourse, homework assignments and tests. International Journal of Science Education, 20(7), p. 769-782, 1998.

ZOLER,U. ; PUSHKIN, D. Matchng higher-order cognitive skills (HOCS) promotion goals with problem-based labratory practice in a freshman organic chemistry course. Chemistry Education Research and Practice, 8 (2), p. 153-171, 2007.

ZOLLER, U., DORI, Y.; LUBEZKY, A. Algorithmic and LOCS and. HOCS (Chemistry) Exam Questions: Performance and Attitudes of College Students. International Journal of Science Education. 24 (2), p.185-203, 2002.

ZOLLER, U. Alternative assesment as (critical) means of facilitating HOCSPromoting teaching and learning in Chemistry Education. Chemistry Education: Research and Practice in Europe, 2 (1), 9-17, 2001.

Are lecture and learning: are they compatible? Maybe for LOCS; unlikely for HOCS. Journal of Chemical Education, 70 (3), p.195-197, 1993.

ZULIANI, S.R.Q.A. A utilização da Metodologia Investigativa na Aprendizagem de Química Experimental. Tese de mestrado em Educação para as Ciências. UNESP, Bauru, 2000. 


\section{Anexos}

\section{ANEXO A - Questionário respondido pela professora A}

Questões pessoais

1. Qual sua formação acadêmica e atuação profissional?

Sou bacharel e licenciada em Química e tenho mestrado na área de Ensino de Ciências. Atuo no Ensino Médio há 10 anos e também ministro cursos na área de formação de professores.

2. Como é o seu regime de trabalho?

Trabalho na escola média durante 30horas semanais, onde 15 horas são dedicadas às aulas e as restantes são voltadas para reuniões, atendimento a estagiários e para a preparação de atividades e projetos. As outras horas são dedicadas a estudos e trabalhos relativos à formação de professores.

Direcionadas à experimentação

3. Que aspectos você considera importantes na elaboração de uma atividade experimental?

Como diretriz mais importante, diria que as atividades experimentais utilizadas devem ser preparadas de forma coerente com os objetivos do curso e do professor. No caso do Ensino Médio, também devem envolver procedimentos de baixo risco e, preferencialmente, materiais de fácil obtenção.

4. A suas práticas geralmente têm o objetivo de solucionar uma situação problema ou observar um fenômeno já estudado em sala? Por quê?

Como já disse, acho importante haver coerência entre objetivos estabelecidos e o planejamento de práticas experimentais. No caso do curso de Química para o Ensino Médio, procuro utilizar os experimentos de forma a:

- desencadear idéias e suscitar questões por parte dos alunos;

- fornecer dados que colaborem para que os alunos cheguem à resolução de problemas ou questões propostas por mim;

- levar os alunos a refletirem sobre suas idéias relativas à fenômenos ou conceitos.

O trabalho de caráter investigativo, onde os alunos não fazem experimentos só para comprovar uma teoria previamente exposta, colabora para o desenvolvimento das capacidades de levantar hipóteses, planejar ações, analisar informações, estabelecer relações e chegar a conclusões. Essas capacidades são muito importantes na formação de um indivíduo reflexivo e crítico, que é um dos objetivos do curso de Química e está apontado na proposta pedagógica da escola.

5. Com quais objetivos, você elaborou o experimento da densidade?

Fornecer dados para que os alunos construíssem o conceito de densidade (relação entre massa e volume) como uma propriedade de cada material que independe da sua quantidade.

6. Você considera que foram atingidos?

Sim, os resultados das avaliações escritas mostraram que o conceito foi compreendido e aplicado na resolução de situações problema.

7. Com quais objetivos, você elaborou o experimento de ponto de ebulição?

Levar os alunos a refletirem sobre as idéias que traziam a respeito da temperatura de ebulição dos materiais e compreender os fatores que a afetam.

8. Você considera que foram atingidos?

Parcialmente. Considero que foi compreendido que a temperatura de ebulição não é afetada pela massa, nem pelo volume e nem pela intensidade da chama utilizada no aquecimento do material. Também foi compreendido que materiais diferentes possuem pontos de ebulição diferentes. 
Os alunos tentaram estabelecer uma relação entre densidade e temperatura de ebulição, (quanto maior a densidade, maior a temperatura de ebulição) mas fiz uma discussão de para levar à idéia de que essa relação não pode ser estabelecida. O que discutimos foi que materiais diferentes apresentam densidades diferentes e provavelmente, pontos de ebulição diferentes.

Os alunos não compreenderam a influência da pressão sobre a temperatura de ebulição dos materiais. Isso pode ter ocorrido em função da não compreensão do experimento. $\mathrm{O}$ mecanismo adotado durante a atividade para a redução da pressão não é óbvio e exige um certo grau de abstração que não foi atingido pelos alunos naquele momento.

Esse ponto será retomado novamente para que os alunos tenham a oportunidade de refletir novamente sobre ele.

9. Qual importância você atribui a experimentos que comprovem teorias por observação? Eles podem ser utilizados se forem coerentes com os objetivos do professor. Podem ajudar os alunos a enxergarem algo que foi visto somente no papel.

10. Qual atitude você toma quando um experimento não atinge as expectativas esperadas, por exemplo, se o experimento der errado.

Não existe experimento que deu errado. É importante que os alunos tenham clareza de que a variabilidade de resultados faz parte do caminhar da Ciência. Os resultados devem ser discutidos, assim como possíveis fatores de variabilidade experimental.

11. Você considera importante, experimentos desenvolvidos a partir de um problema ou na forma de testagem de hipóteses?

Sim. Acho que levam os alunos a um processo de análise e reflexão bem significativo.

12. Após a realização do experimento, como a aula prossegue?

Os resultados obtidos e as possíveis variações são analisados por todo o grupo de alunos, orientados pelo professor. Como fechamento do trabalho, o grupo de alunos, auxiliado pelo professor, formula conclusões.

13. Você considera importante o trabalho em grupo?

Sim. As discussões nos grupos de trabalho auxiliam no processo de reflexão e análise. Há também o aprendizado de como ouvir e lidar com diferentes posturas e opiniões.

14. Você considera importante conhecer as idéias iniciais dos alunos? Como isso pode contribuir no planejamento e aplicação das atividades práticas?

Sim. Muitas vezes, as idéias prévias trazem conceitos que são incompatíveis com o que é aceito cientificamente. Nesse caso, o professor deve planejar atividades que possibilitem ao aluno refletir sobre elas. Os experimentos que forneçam resultados que se contrapõem às idéias prévias dos alunos podem levá-los a rever o que pensavam sobre as questões abordadas.

15. Ao preparar um a atividade prática você considera as questões CTS?

Sim. Considero que é importante estabelecer relações entre o problema a ser investigado e contextos, que podem ser de ordem tecnológica, social, histórica, política ou econômica.

16. Quais meios de pesquisa você utiliza para a elaboração das atividades, por exemplo, revistas, livros, etc?

Utilizo livros e revistas que apresentem foco no ensino de Ciências. Também faço consultas à internet.

As trocas de experiências com colegas também são muito importantes.

17. Dentre estas habilidades que podem ser desenvolvidas na atividade experimental, cite o grau de importância e explique a escolha: 


\begin{tabular}{|c|c|c|c|}
\hline Objetivos Pedagógicos & $\begin{array}{c}\text { Muito } \\
\text { Importante }\end{array}$ & Importante & $\begin{array}{c}\text { Pouco } \\
\text { Importante }\end{array}$ \\
\hline Motivar e estimular o interesse do aluno. & $\mathrm{X}$ & & \\
\hline $\begin{array}{l}\text { Ensinar habilidades de laboratório, manipulação de } \\
\text { instrumentos. }\end{array}$ & & & $\mathrm{X}$ \\
\hline $\begin{array}{l}\text { Promover a compreensão da natureza das ciências, como } \\
\text { os cientistas trabalham. }\end{array}$ & $X$ & & \\
\hline Aumentar a aprendizagem de conceitos científicos. & $\mathrm{X}$ & & \\
\hline $\begin{array}{l}\text { Desenvolver atitudes científicas como objetividade, } \\
\text { precisão. }\end{array}$ & $\mathrm{X}$ & & \\
\hline $\begin{array}{l}\text { Desenvolver habilidades cognitivas como pensamento } \\
\text { crítico, elaboração de hipóteses, síntese. }\end{array}$ & $\mathrm{X}$ & & \\
\hline \multicolumn{4}{|c|}{$\begin{array}{l}\text { Justificativas: } \\
\text { Acredito que a aprendizagem de técnicas de laboratório não são primordiais para a formação de um } \\
\text { indivíduo reflexivo. } \\
\text { A aprendizagem da natureza da Ciência como algo que não é uma coleção de verdades absolutas é } \\
\text { muito importante. É também importante levar à reflexão de que a Ciência não está isolada de contextos } \\
\text { sociais, econômicos e políticos. } \\
\text { O trabalho experimental desperta a curiosidade e o interesse do aluno e o leva a formular questões, o } \\
\text { que é muito importante. Essas questões auxiliam na aprendizagem de conceitos científicos e favorecem } \\
\text { o desenvolvimento de habilidades cognitivas. } \\
\text { Também é importante que os alunos saibam descrever observações de maneira clara e objetiva, para } \\
\text { que sua análise seja feita de forma coerente. Isso pode ser aplicado não só ao aprendizado de Ciências }\end{array}$} \\
\hline
\end{tabular}




\section{ANEXO B - Questionário respondido pela professora B}

Questões pessoais

1. Qual sua formação acadêmica e atuação profissional?

\section{Formação Acadêmica:}

Graduação - Universidade Mackenzie (1993-1998), licenciatura plena e bacharelado em Química, habilitação em Química, Física e Matemática (fundamental II);

Graduação - Universidade de Guarulhos (1999-2001), licenciatura plena com habilitação em administração e supervisão escolar);

Pós-Graduação - Universidade Oswaldo Cruz (2003-2004), especialização em Química;

Aluna especial - Universidade de São Paulo (2005), disciplina: "Estratégias Alternativas para o Ensino de Bioquímica".

Pós Graduação - Universidade de São Paulo (2006 - cursando), Mestrado em Ensino de ciências - modalidade Química)

\section{Atuação profissional:}

1990 a 1993 - outros

1993 a 2008 - Área Educacional: professora de Química, Física, Ciências e Matemática;

2008 - Coordenadora Pedagógica da Prefeitura Municipal de São Paulo.

2. Como é o seu regime de trabalho?

Se entendi a sua pergunta, acredito que quer saber qual o meu horário de trabalho?

São 22 aulas semanais e mais 2 HTPCs, como regente das turmas em que seus dados e os meus foram coletados.

Direcionadas à experimentação

3. Que aspectos você considera importante na elaboração de uma atividade experimental?

Considero que a atividade experimental deve estar relacionada com o conteúdo que está sendo trabalho de forma a auxiliar na aprendizagem dos alunos. Também a disponibilidade de material, principalmente a falta de reagentes prejudica a elaboração de atividades mais diversificadas.

4. As suas atividades práticas geralmente têm o objetivo de solucionar uma situação problema ou observar um fenômeno já estudado em sala? Por quê?

As atividades experimentais apresentadas aos alunos tinham como objetivo colocá-los em contato com algumas situações para que eles mesmos, mediados por minhas intervenções, pudessem observar as características dos experimentos, antes e após a sua execução. O material utilizado abordava os conteúdos em uma certa sequiência, que permitia aos alunos, cada vez mais irem reelaborando seu conhecimento a partir de uma atividade proposta, que exigia sempre a mobilização de conhecimentos interiorizados anteriormente. 
5. Com qual objetivo você elaborou e executou o experimento do ponto de fusão?

Este experimento tinha como objetivo direcionar o olhar do aluno para identificação de materiais que apresentavam características próprias (específicas) ou não, até que conseguissem identificar se um material é uma substância simples ou uma mistura, através de suas propriedades específicas. Para tanto, também foram estudados outros pontos, como o PE, densidade, solubilidade.

6. Você considera que foram atingidos?

Acredito que sim, pelo menos para a maioria dos alunos ficou claro este ano, quando trabalharam com o material enviado pelo Governo do Estado de São Paulo, e conseguiram identificar claramente as atividades propostas.

7. Qual importância você atribui aos experimentos que comprovam teorias por observação?

Bom, a meu ver os experimentos não devem ser utilizados com o objetivo de comprovar teorias e sim auxiliar na construção do conhecimento pelo aluno, através de atividades direcionadas.

8. Você considera importante, experimentos desenvolvidos a partir de um problema ou na forma de testagem de hipóteses?

Sim porque permite aos alunos articularem suas próprias idéias a algo já previsto, propondo novas hipóteses para a resolução de problemas.

9. Você considera importante o trabalho em grupo?

Com certeza, porque permite a interação e o convívio com seus semelhantes, para que possam aprender a respeitá-los, considerando seus conhecimentos e seus tempos de aprendizagem, através da troca de experiências vividas e que possam ser aplicadas para as atividades em questão.

10. Você considera importante conhecer as idéias iniciais dos alunos? Como isso pode contribuir no planejamento e aplicação das atividades práticas?

As idéias iniciais dos alunos servem como parâmetro para direcionar o planejamento e discurso do professor em sala de aula, porque é através desta sondagem que o professor vai direcionando seu trabalho.

11. Dentre estas habilidades que podem ser desenvolvidas na atividade experimental, cite o grau de importância e explique a escolha:

\begin{tabular}{|l|l|l|l|}
\hline \multicolumn{1}{|c|}{ Objetivos Pedagógicos } & $\begin{array}{l}\text { Muito } \\
\text { Importante }\end{array}$ & Importante & $\begin{array}{l}\text { Pouco } \\
\text { Importante }\end{array}$ \\
\hline Motivar e estimular o interesse do aluno. & $\mathrm{x}$ & & \\
\hline $\begin{array}{l}\text { Ensinar habilidades de laboratório, } \\
\text { manipulação de instrumentos. }\end{array}$ & & $\mathrm{X}$ \\
\hline $\begin{array}{l}\text { Promover a compreensão da natureza das } \\
\text { ciências, como os cientistas trabalham. }\end{array}$ & $\mathrm{X}$ & \\
\hline $\begin{array}{l}\text { Aumentar a aprendizagem de conceitos } \\
\text { científicos. }\end{array}$ & $\mathrm{X}$ & \\
\hline $\begin{array}{l}\text { Desenvolver atitudes científicas como } \\
\text { objetividade, precisão. }\end{array}$ & $\mathrm{X}$ & \\
\hline
\end{tabular}




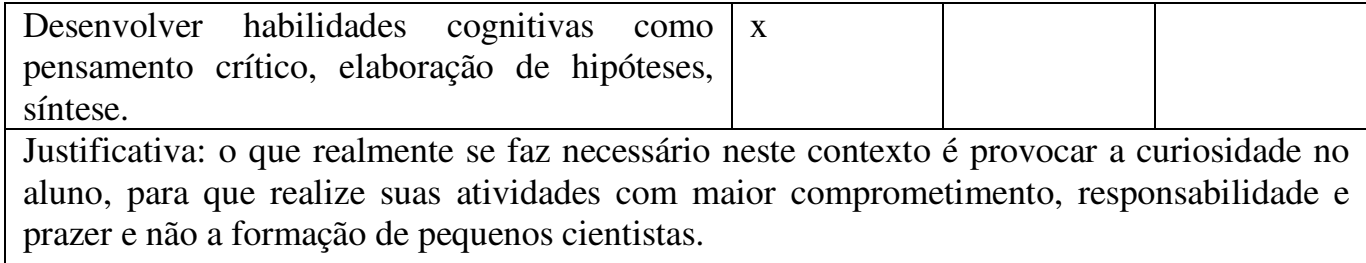

12. A frase abaixo se refere à postura construtivista:

"Na perspectiva construtivista, as atividades são organizadas considerando as concepções prévias dos alunos. Nesta concepção, os experimentos são desenvolvidos na forma de problemas ou testagem de hipóteses, envolvendo o cotidiano do aluno. A postura construtivista aceita que nenhum conhecimento é assimilado do nada, mas deve ser reconstruído pela estrutura de conceitos já existentes. A discussão e diálogo são de suma importância para combinar ação e reflexão."

Você poderia utilizar esta definição para caracterizar as atividades experimentais que você realiza em sala? Por que?

Sim porque os experimentos levaram os alunos a refletir sobre a idéias que tinham anteriormente sobre os assuntos propostos e isto eles só conseguiram fazer porque estavam trabalhando em grupo, refletindo e discutindo sobre suas falas, até chegarem a uma conclusão comum ao grupo.

13. As atividades experimentais podem ser definidas segundo alguns autores como segue:

"As atividades de demonstrações têm o objetivo de ilustrar o que foi falado, de comprovar um conteúdo já ensinado, ou seja, mostrar, aos alunos, que o professor estava certo. Já as atividades de caráter investigativo, buscam questão problematizadora que ao mesmo tempo desperte a curiosidade e oriente a visão do aluno sobre as variáveis relevantes do fenômeno a ser estudado, fazendo com que eles levantem suas próprias hipóteses e proponham possíveis soluções.“

Alguma dessas abordagens pode definir as atividades experimentais que você realiza em sala? Por que?

O caráter investigativo com certeza define bem nossas atividades, porque a ação, reflexão e proposição de soluções, após as observações constantes, estiveram a todo momento presentes em nossas atividades. 


\section{ANEXO C - Experimento Densidade: Protocolo experimental}

\section{Determinacão da densidade de materiais} materiais.

Vocês já estudaram que a densidade é uma propriedade que pode auxiliar a identificar os

Nesta atividade, vocês farão medidas de densidades de materiais líquidos e sólidos para procurar identificá-los.

\section{Medidas da densidade de materiais sólidos}

Vocês estão recebendo duas amostras de sólidos diferentes. Para a determinação das densidades de cada um deles, você deverá fazer medidas que permitam identificar suas massas e seus volumes.

a) Medidas de massas

Pesem os sólidos separadamente e anotem o valor das massas obtidas.

Massa do sólido $1=46,14 \mathrm{~g}$

Massa do sólido $2=17,25 \quad g$

b) Medidas de volume's

$$
3=7,148
$$

Vocês utilizarão o mesmo procedimento para os dois sólidos, sendo que as medidas devem ser feitas separadamente.

Coloquem na proveta um volume de água suficiente para encobrir o sólido a ser estudado.

Anotem o volume inicial de água.

Volume inicial da água $=130 \mathrm{~mL}$ (sólido 1$)$

$\begin{aligned} \text { Volume inicial da água } & =\frac{80}{80} \mathrm{~mL} \\ = & =80 \text { (sólido } 2)\end{aligned}$

Mergulhem o sólido na água.

Anotem o volume final da água.

Volume final da água $=148 \mathrm{~mL}($ sólido 1$)$

Volume final da água $=\frac{.83}{82} \mathrm{~mL}$ (sólido2)

Calculem o volume do sólido.

Volume do sólido $1=18 \mathrm{~mL}$

Volume do sólido2 $=\frac{3}{2} \mathrm{~mL}$

c)Calcule a densidade das amostras

Densidade do sólido $1=.2,56 \mathrm{~g} / \mathrm{mL} \subset \mathrm{OK}$ !

Densidade do sólido $2=5,75 \mathrm{~g} / \mathrm{mL} C \mathrm{C}, 92 \mathrm{~g} / \mathrm{mL}$

$$
=\frac{3,578 / m e}{3}, 57,14 \mathrm{~g} / \mathrm{mL}
$$

d) Consulte a tabela que está com a professora e procuré identificar o sólido que você recebeu.

A amostra 1 é_alumínio

A amostra 2 é colvre.

3 é incos

A densidade permitiu a identificação das amostras recebidas? Por quê? .

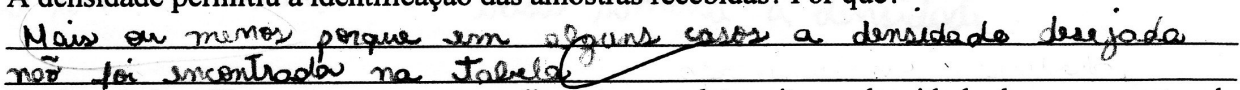

Você poderia utilizar esse mesmo procedimento para determinar a densidade de uma amostra de sal de cozinha? Por quê?

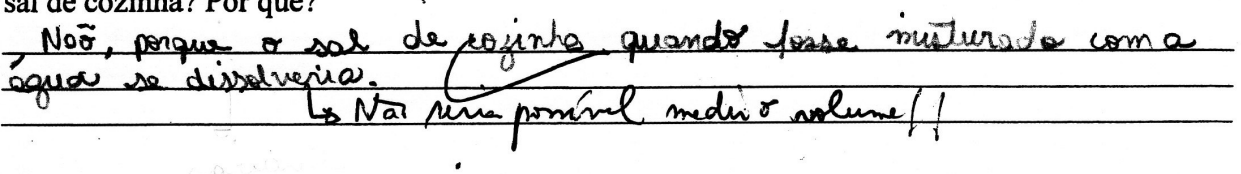




\section{Medidas da densidade de materiais líquidos}

Vocês estão recebendo duas amostras de líquidos diferentes. Para a determinação das densidades dos materiais, vocês deverão utilizar os densímetros.

Observem os densímetros que vocês estão recebendo. Eles são diferentes? Por quê?

Sim, un tem chume no fundo e o outro tem chumbo com

una rasina, dejendr, cons gue a cor de un e de reitro seja diferente. A escala também í difprente.

Vocês utilizarão o mesmo procedimento para os dois líquidos, sendo que as medidas devem ser feitas separadamente.

Coloquem cerca de $90 \mathrm{~mL}$ do líquido na proveta.

Mergulhem o densímetro no líquido e verifiquem qual dos densímetros é adequado para a medida. (O densímetro deve ficar flutuando no líquido).

Em seguida, façam uma leitura cuidadosa da escala e determinem o valor da densidade do material.

Densidade do líquido $1=0,790 \quad \mathrm{~g} / \mathrm{mL}$

Densidade o líquido $2=\frac{0,120}{12} \mathrm{~g} / \mathrm{mL}$

Compare com os valores da tabela fornecida pelo professor e procure identificar o líquido estudado.

A amostra 1 é '́lcool

A amostra 2 é éguai conv. sal

A densidade permitiu a identificação das amostras recebidas? Por quê?

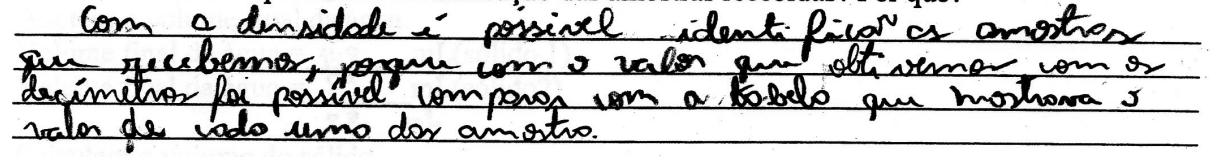

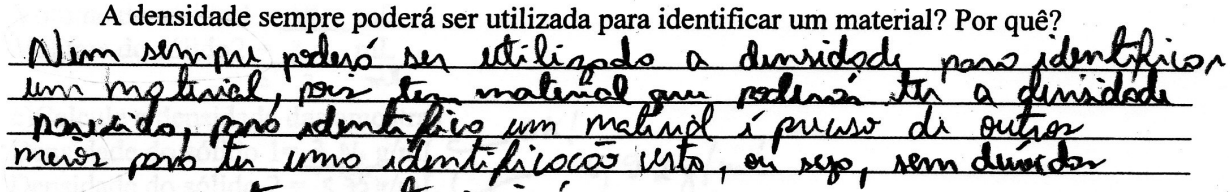
qui sego outros matrioin.

Mo nosso coss (neste experimento) for posivel a identifh:-

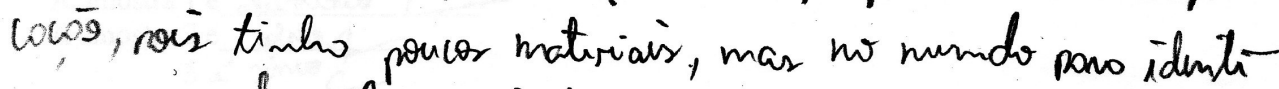
ciw um material nos basto somente a densidode. 


\section{ANEXO D - Experimento Densidade: Questões para fechamento do assunto}

Retomando o conceito de densidade

1) Analise as afirmações a seguir e diga se você concorda ou não com cada uma. Justifique suas respostas.

a) A niassa de $100 \mathrm{~mL}$ de mercúrio é diferente da massa de $50 \mathrm{~mL}$ de mercúrio.

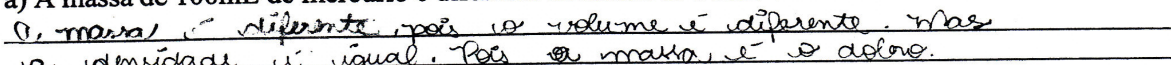
a densidade i' igual. Pois masta, it do doro.

b) O volume de $1 \mathrm{~kg}$ de algodão é igual ao volume de $10 \mathrm{~kg}$ de algodão.

O) velume, no is iqual pois a marra í diferent

c) A densidade de $2 \mathrm{~kg}$ de álcool é diferente da densidade de $1 \mathrm{~kg}$ de álcool.

c) denvidade le laval, ais voci aumenta ndo ou dimi-nuindo la masra ru o volume, a densidade tem que dar, ia merma.

d) Á densidade de $100 \mathrm{~mL}$ de água é diferente da densidade de $300 \mathrm{~mL}$ de água. a denidade é a mesma. Porque tem wo musmo. material

2) A densidade pode ser utilizada para auxiliar na identificação de um material? Por quê? Poder porque a inelaccio massa/volume tim sempre que ser va mismà, se voè tiver umas tabela, vori consegue idintislicar

3) Por que um material flutua em outro?

Um material llutua en outro, porque depende das concentracăo das massas. O corpo depende da densidade

4) Sabendo que o gelo flutua na água, discuta se a temperatura pode ou não afetar a densidade de um material.

um itemperatara after na densidade. 
ANEXO E - Experimento Temperatura de Ebulição: Plano prévio de um grupo

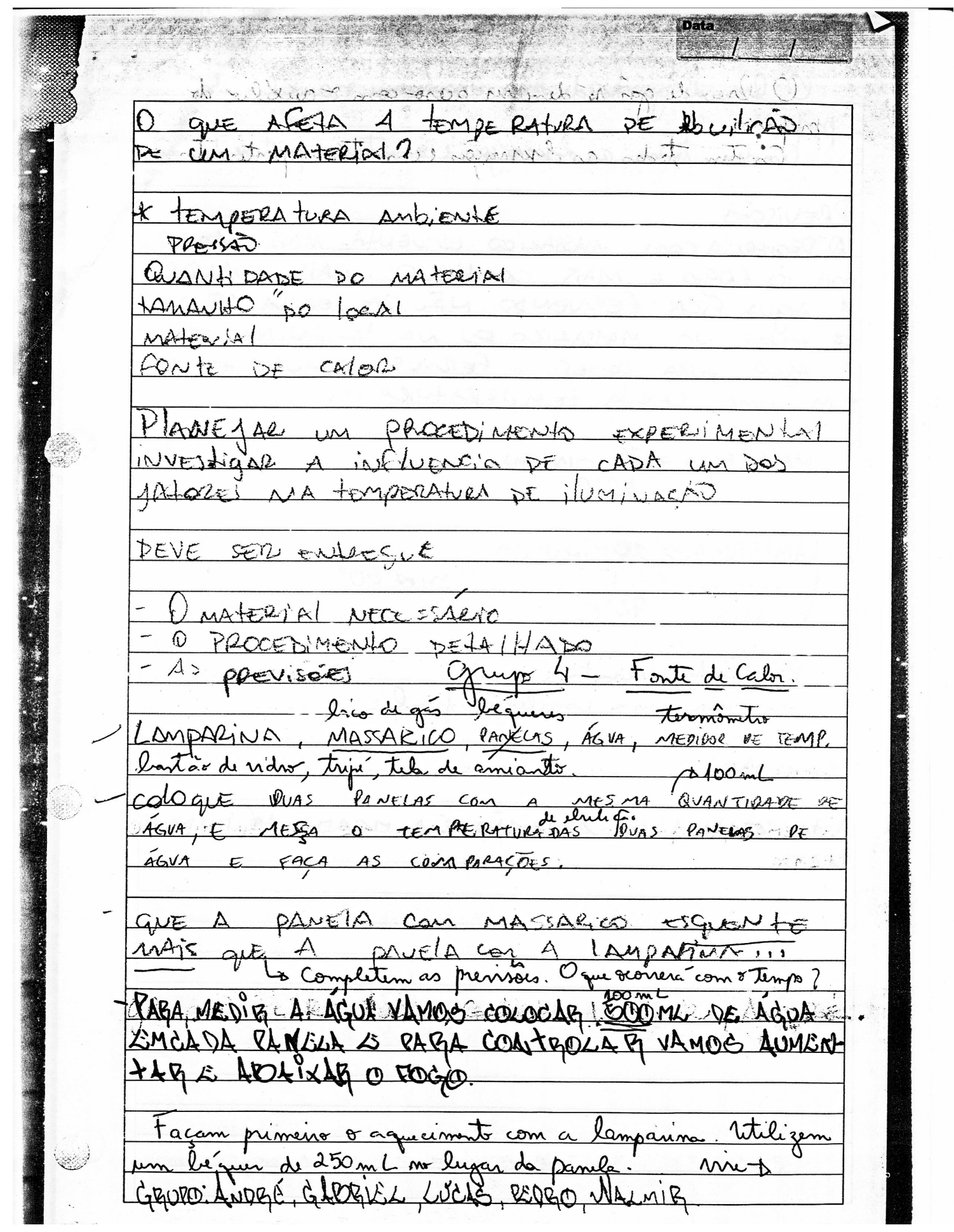




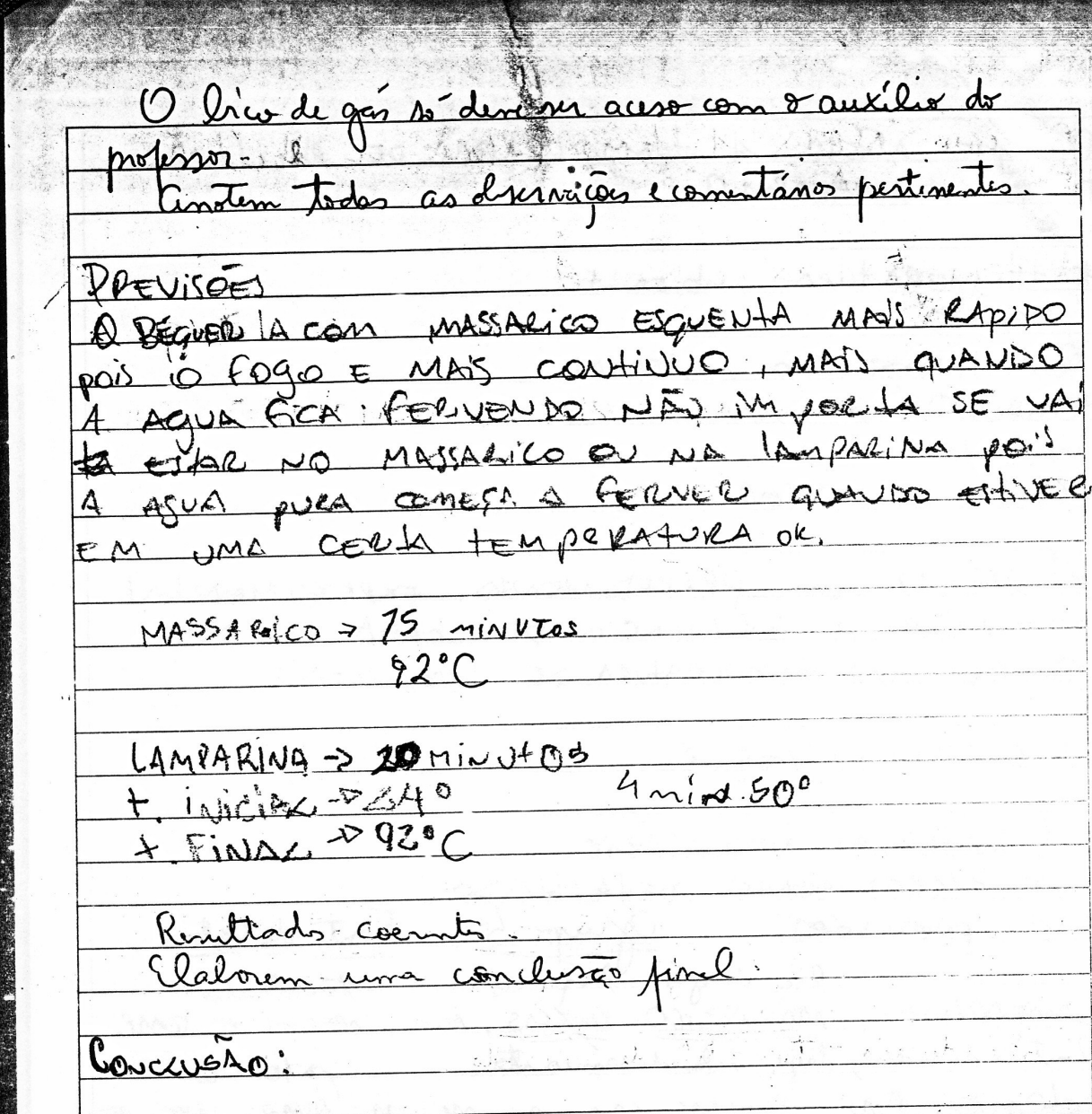

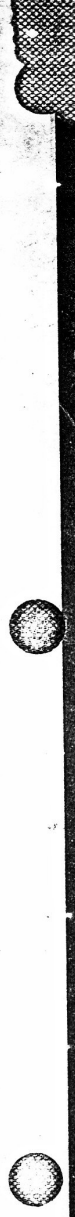

A temPERATURA dE EBOLICÁ̃O tEMRO.

A $\quad 3 \quad+2+1$

2

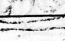


ANEXO F: Experimento Temperatura de Ebulição: Relatório final de um aluno

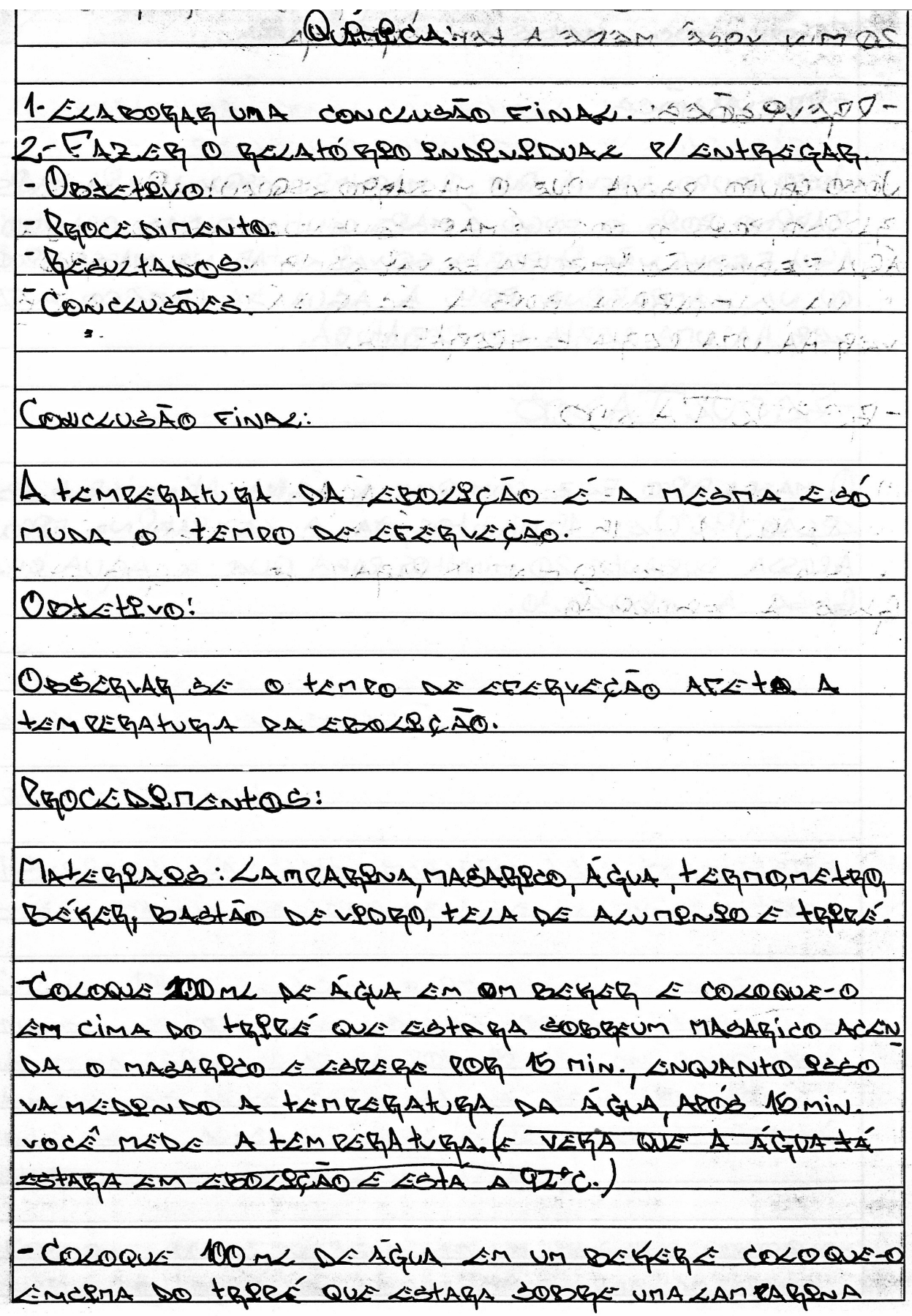




\section{ANEXO G - Experimento Temperatura de Ebulição: Questões Pós-Laboratório}

\section{Atividade - Refletindo sobre os fatores que afetam a temperatura de ebulição de um material}

Nas aulas anteriores, foram realizados experimentos para investigar quais fatores influiriam scbre a temperatura de ebulição de um material. Vocês levantaram várias hipóteses e cada uma foi investigada por um grupo. Analisando os experimentos feitos e as explicações dadas para os diferentes resultados, responda às questões a seguir:

1 - Considere o experimento feito para investigar se a alteração do material causaria modificações na temperatura de ebulição.

a) O que foi mantido constante? A QuantIOADE de materiaIs e a FONTE De calOR, FORAM MANTIOAS CONSTANTE.

b) O que foi variado? T TIPO DO MATERIAL FOI VARIADO.

c) A alteração do material causa quais modificações no processo de ebulição? A moOIfICAÇ OCORRE NA TEMPERATURA DE EBULICĀ̃o.

DO VOLUME.

2 - Considere o experimento feito para investigar se a alteração da massa de um material (quantidade) causaria modificações na sua temperatura de ebulição.

a) O que foi mantido constante? O MATERIAL E A CHAMA FORAM MANTIDOS CONSTANTE.

b) O que foi variado? O VOLUmE DE agUA (QUANTI DAOE) FOI VARIADO

00 vocume

c) A alteração da massa de um material causa quais modificações no processo de ebulição? a moolficagá̃ ocorre no tempo que a água leva para ENTRAR EM EBULICĀD.

3 - Considere o experimento feito para investigar se a alteração da temperatura ambiente causaria modificações na temperatura de ébuilição de um material.

a) O que foi mantido constante? A QUANTIDADE DE ÁGUA, O MATERIAL, $E$, teoricamente a chama foram mantidos cOnstantes.

b) O que foi variado? A TEMDERATURA INICIAL DO MATERIAL FOI VARIADF

c) A alteração da temperatura ambiente causa quais modificações no processo de ebulição? SOMENTE a mudanga DO tempo de EBULIGÃo. 
4 - Considere o experimento feito para investigar se a alteração da intensidade da chama causaria modificações na temperatura de ebulição de um material.

a) O que foi mantido constante? O MATERIAL E A QUANTIDADE FORAM MANTIOOS CONSTANTES

b) O que foi variado? A FONTE DE CALOR FOI VARLADA

c) A alteração da intensidade da chama causa quais modificações no processo de ebulição de um material? MUNOO O TEMPO DË EBULI GÃO.

5 - Considere o experimento feito para investigar se a alteração da pressão do ambiente causa modificações na temperatura de ebulição de um material.

a) $\mathrm{O}$ que ocorreu com a pressão dentro do balão? Por que isso ocorreu?

A PRESSÃ DO BALÃ DIMINUI, POIS O VAPOR DA ÁGUA VOLTA A SER água dIMINUINDO a QUANTIDADE de GASES.

b) A alteração da pressão ambiente causa quais modificações no processo de ebulição de um material?

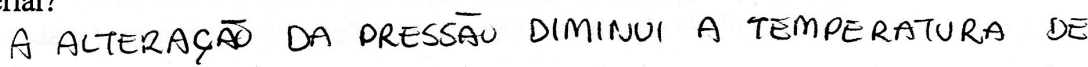

EBULIQAFO. 


\section{ANEXO H - Entrevista com um aluno da Escola A}

E. Tá, Al. Você acha importante quando a professora realiza experimento?

Al. Ah, eu acho muito importante. É uma maneira diferente da gente começar a ter mais contato, aprender. É uma maneira... Que é mais fácil da gente entender, não só ouvindo, mas vendo, tocando.

E. Melhor do que se fossem só aulas teóricas?

Al. É. Acho que se fosse só teórico passava muito por cima, a gente não ia entender bem direitinho as coisas.

E. E você gosta?

Al. Eu gosto. Legal.

E. Você lembra que a professora tava explicando densidade, ela mostrou o volume do algodão. Lembra?

Al. Haham

E. Depois ela mostrou o volume do chumbo. Depois vocês chegaram a relacionar massa e volume. Ela colocou o volume da água, chegou nessa relação do álcool. Aí vocês foram pro laboratório realizar experimento. O que você aprendeu com todos esses experimentos que ela realizou? Tanto o que ela realizou ela na bancada e o que vocês fizeram.

Al. Massa e volume, assim?

E. É. Qual era o objetivo do experimento? O que valeu para você realizar o experimento? O que você aprendeu?

Al. Ah, que ela quis mostrar qual é a diferença do chumbo pra algodão. Que são coisas completamente diferente, mas que a massa, elas podem ser iguais se tiver quantidade diferente das coisas. Então a massa de um chumbinho pode ser igual a massa de um chumaço de algodão. Porque o volume também é importante.

E. Aí vocês foram pro laboratório verificar a densidade dos materiais. Aí, qual era o objetivo central do experimento? Era só verificar densidade?

Al. Ah, acho que era a partir da... Que eu lembro que a gente às vezes identificou a densidade sem saber o que que era. Então eu acho que era para ver se a partir da densidade a gente podia identificar alguns materiais.

E. Aí depois vocês discutiram o ponto de ebulição. Ela explicou o que era ponto de ebulição, colocou a diferença entre ebulição e evaporação. Aí vocês foram pro laboratório de novo, o que você aprendeu com esse experimento?

Al. Que a gente criou, né? Esse foi o que a gente criou, né? 
E. Isso

Al. Ah, então, o meu era de volume, né? Massa e volume. A relação de massa mais volume no tempo de ebulição. A gente aprendeu que tem...que o ponto de ebulição é o mesmo com uma pequena variação de... ou de termômetro... mas que há um tempo de ebulição....que o ponto de ebulição é o mesmo independente da massa. A temperatura é a mesma independente da quantidade.

E. Então o ponto de ebulição dá pra identificar material também?

Al. Dá

E. Dá?

Al. Dá. Se a gente souber que tempo o leite ebuli, que tempo a água ebuli, dá pra identificar. E. E você gostou de você fazer o experimento? De você fazer o procedimento?

Al. Ah, foi bem diferente. Nunca a gente tinha montado, cada um montar um experimento, verificar. No começo não sabia muito bem, mas aí chegando no final, com as discussões, até depois com o relatório que a gente fez para concluir no geral. Aí a gente gostou bastante, deu pra aprender, foi uma experiência nova.

E. E a professora realiza esse tipo de experimento, como esse que vocês tiveram que elaborar o procedimento, o... Da densidade, vocês não sabiam quais eram aqueles materiais. Vocês tiveram que investigar qual era o material. Então, você prefere esse tipo de experimento que você tem que investigar, que tem que realizar o experimento? Ou você acha que seria melhor se ela já falasse qual era o resultado esperado? Que já falasse que naquelas provetas tinha mel, álcool, algodão e vocês só iam lá medir a densidade. Como que você prefere?

Al. Ah, eu prefiro que a gente ponha a mão na massa, como que se diz assim. Que a gente, sei lá, correr atrás, ver, procurar, comparar as coisas. Acho que é muito mais....acho que os alunos se envolvem mais. Fica uma coisa mais dinâmica. Não fica só ouvindo, ouvindo. Se bem que a gente pode até entender, mas é diferente você ter contato.

E. Vamos dizer que ela tivesse contado, lá do experimento da ebulição, se ela tivesse contato como que vocês deveriam fazer, que a massa não interfere, que a pressão interfere, se ela tivesse falado não teria ...

Al. Teria tanto ganho. Acho que a gente....nem prestava tanta atenção assim, não se interessava tanto. Foi um jeito que ela criou assim de a gente se interessar, fazer um experimento para aí ir verificar a relação de cada uma, massa, volume, nananana, com o ponto de ebulição, com a identificação do material.

E. E você acha que o trabalho em grupo contribuiu pra realizar o experimento, para entender o conceito de densidade e ebulição? 
Al. É que no grupo, assim, é mais fácil porque...grupos muito grandes não, mas grupos menores, assim, tem aquela discussão sadia, cada um dá a sua opinião, seu ponto de vista, o que achou, e aí a partir disso que a gente forma a conclusão, o objetivo das coisas. A gente vai formando junto. Fica uma coisa mais rica.

E. Cada um dá a sua idéia, vai juntando...

Al. É

E. Então, você acha que aprendeu mais com essas aulas de laboratório então do que...

Al. É. Eu acho assim, que no laboratório dá para aprender bastante, mas depois também um fechamento, uma conclusão, tipo uma conversa sobre o que cada grupo concluiu e tal. O que é e o que não é. O que acontece realmente e o que não.

E. Então tem sempre que ter uma discussão depois do laboratório para compreender?

Al. É

E. Não adianta ir pro laboratório fazer e não ter uma explicação depois.

Al. Até o relatório é legal para ver se entendeu mesmo, se todo mundo compreendeu. Aí você vê porque não deu certo o que a gente pensava e tal.

E. Obrigada. Obrigada por você ter deixado eu gravar o seu experimento. Ajudou bastante. Al. De nada 


\section{ANEXO I - Material utilizado na Escola B}

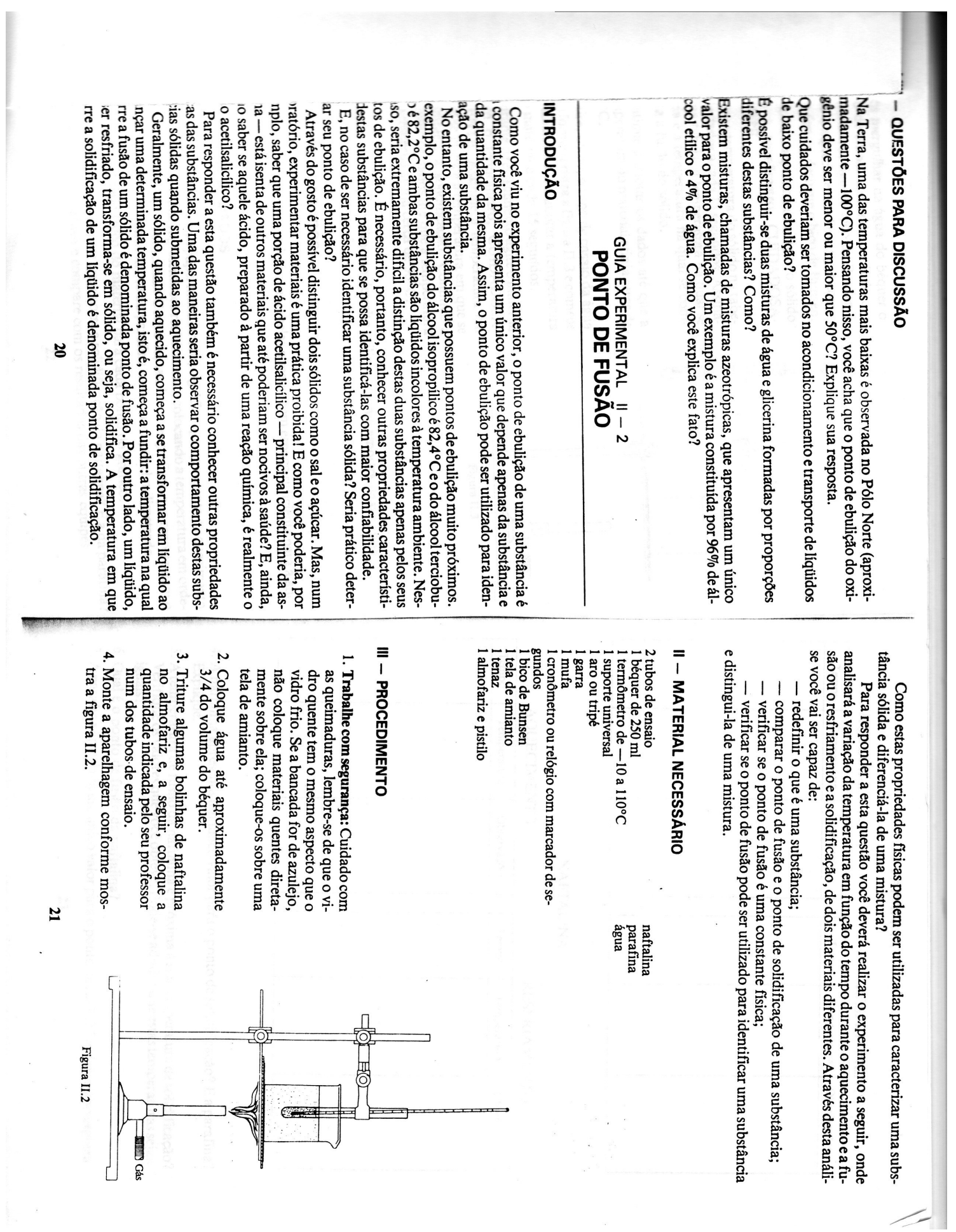




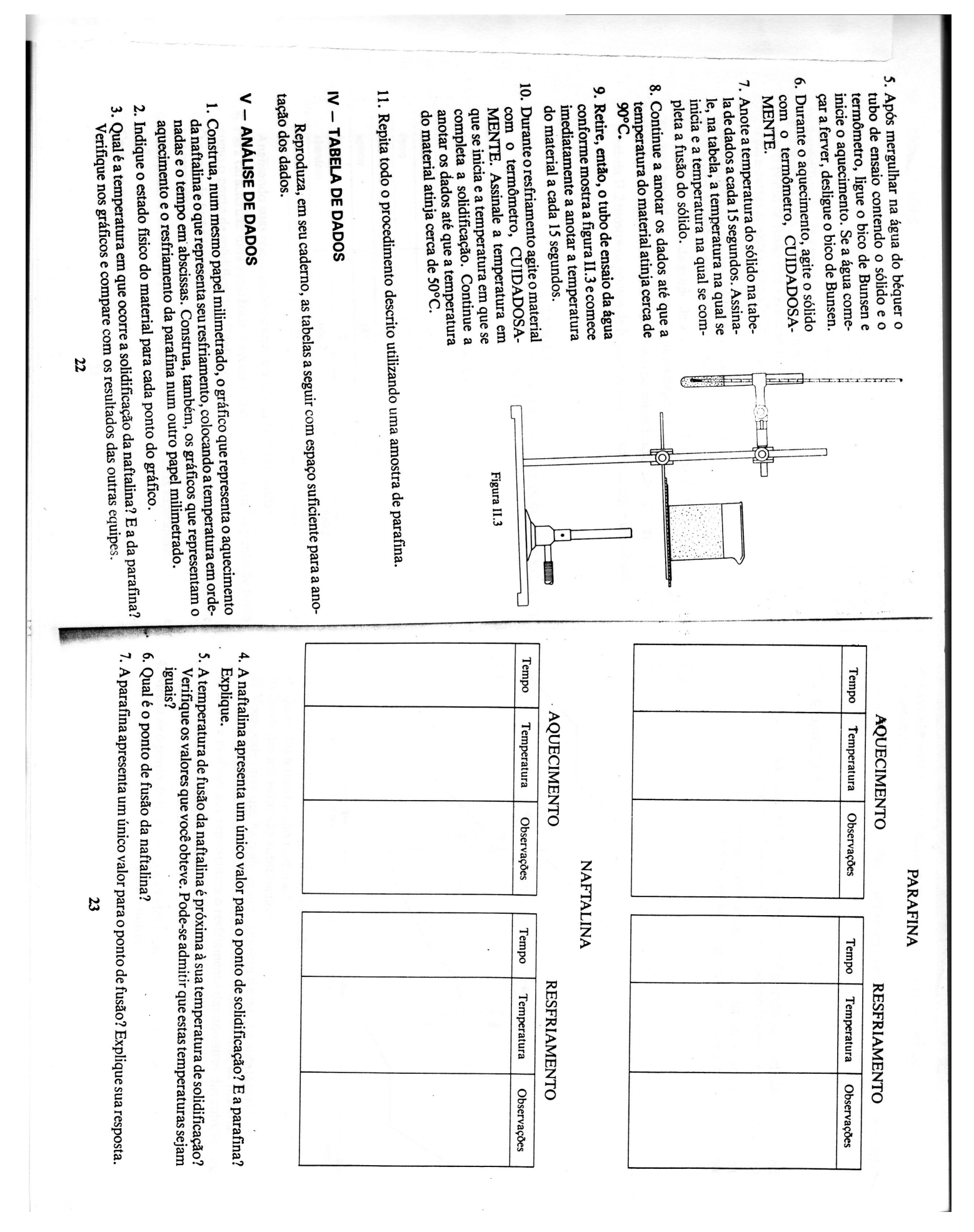




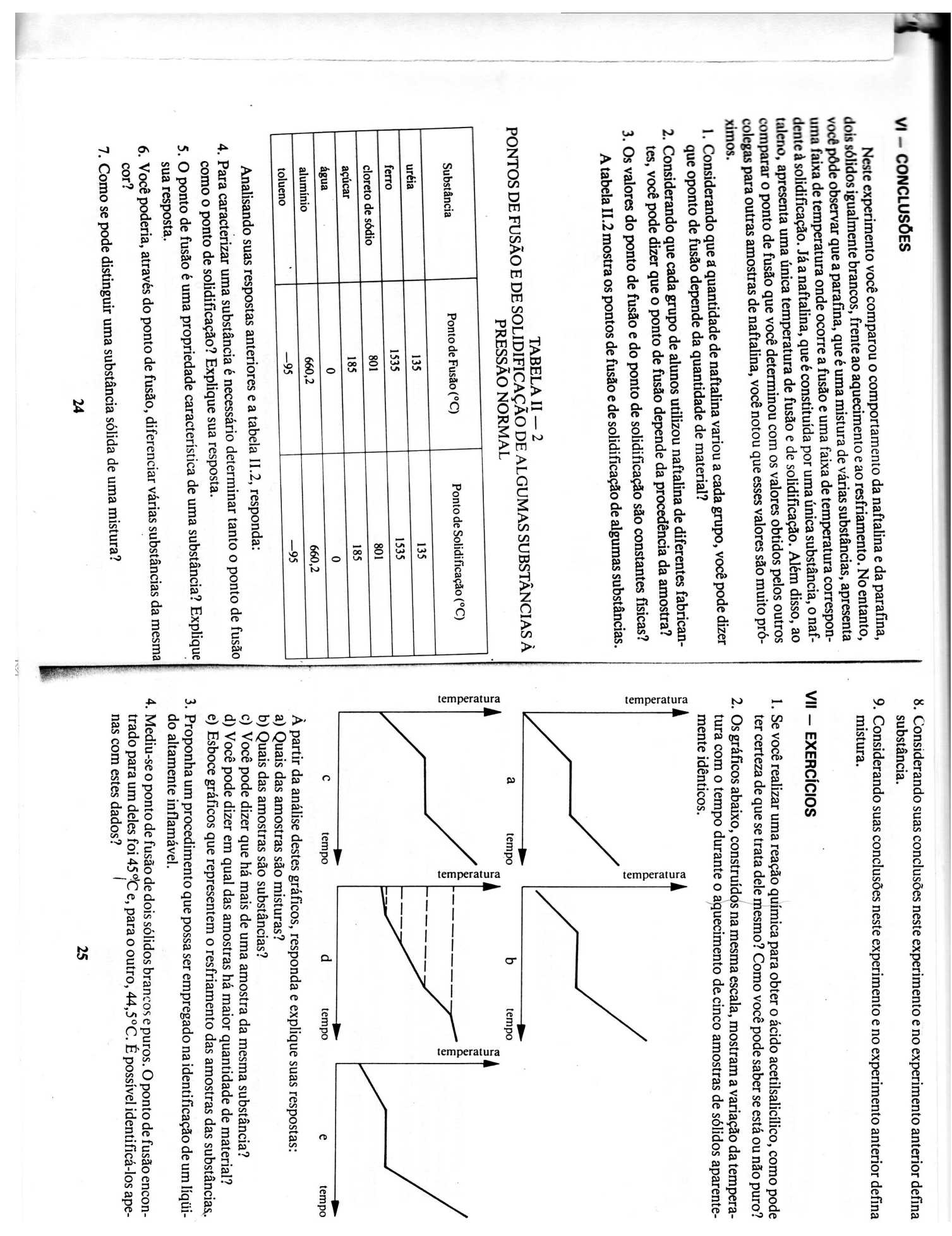




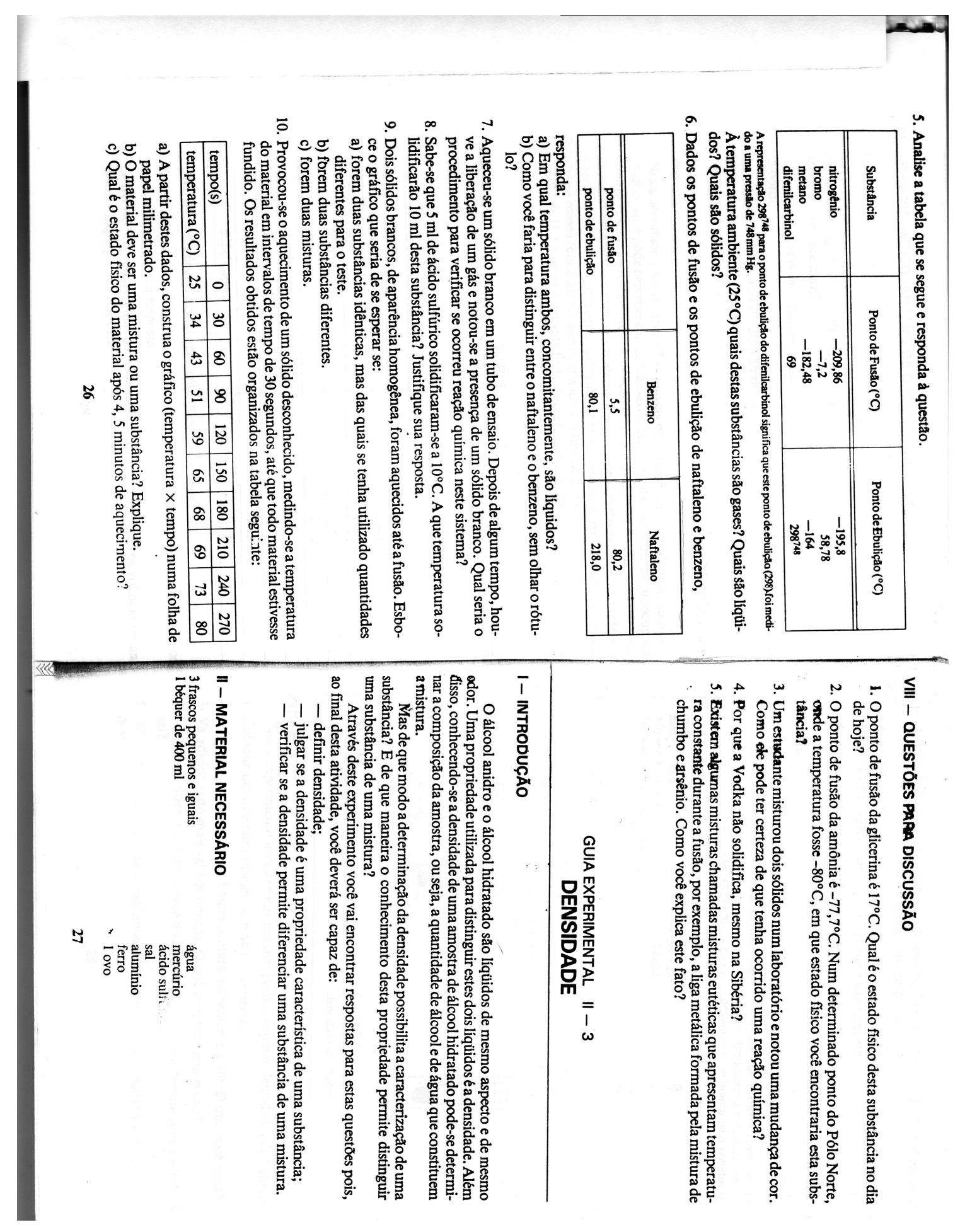


ANEXO $\mathbf{J}$ - Experimento Temperatura de Fusão: Exemplo de material entregue por um aluno

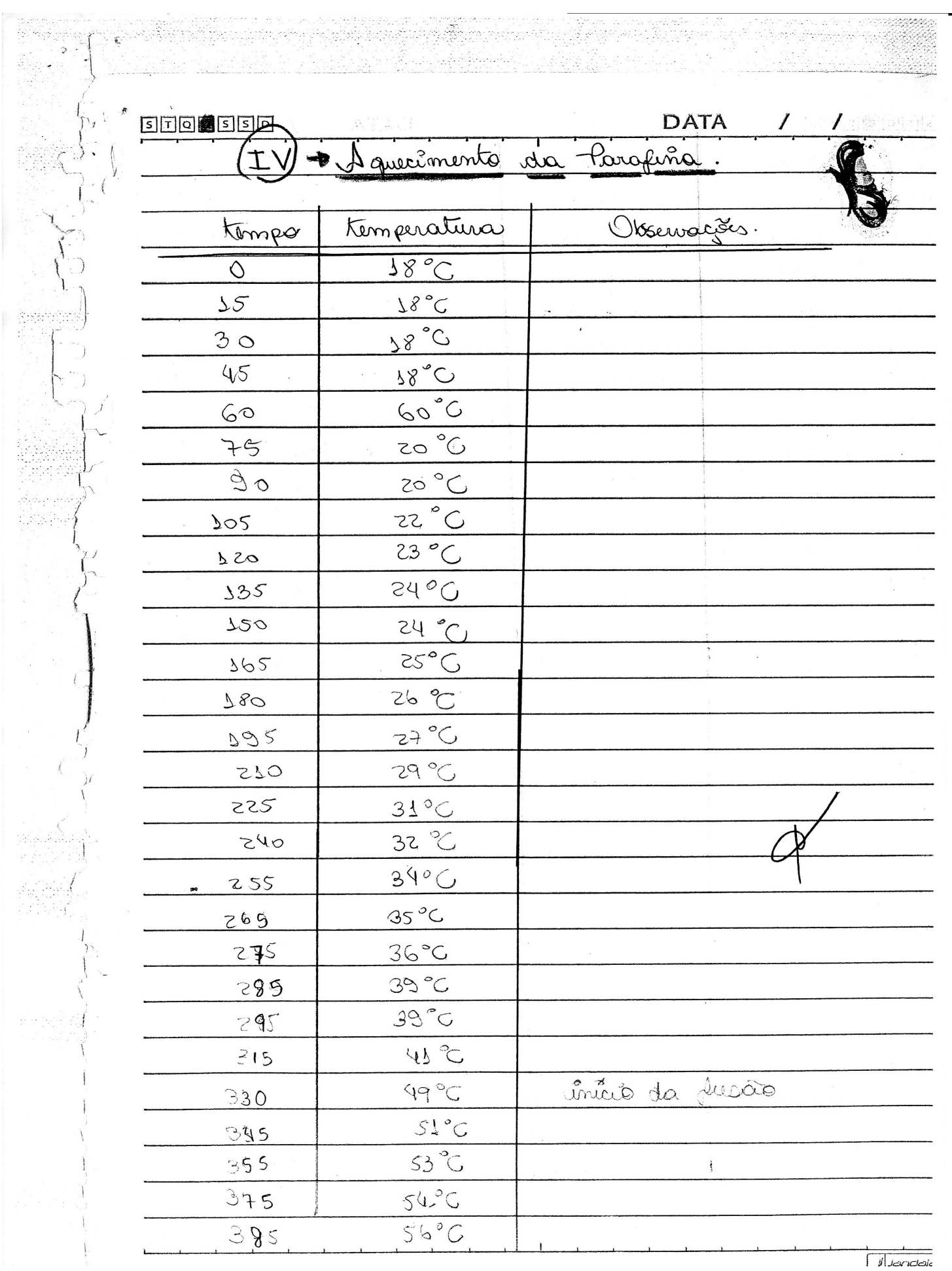




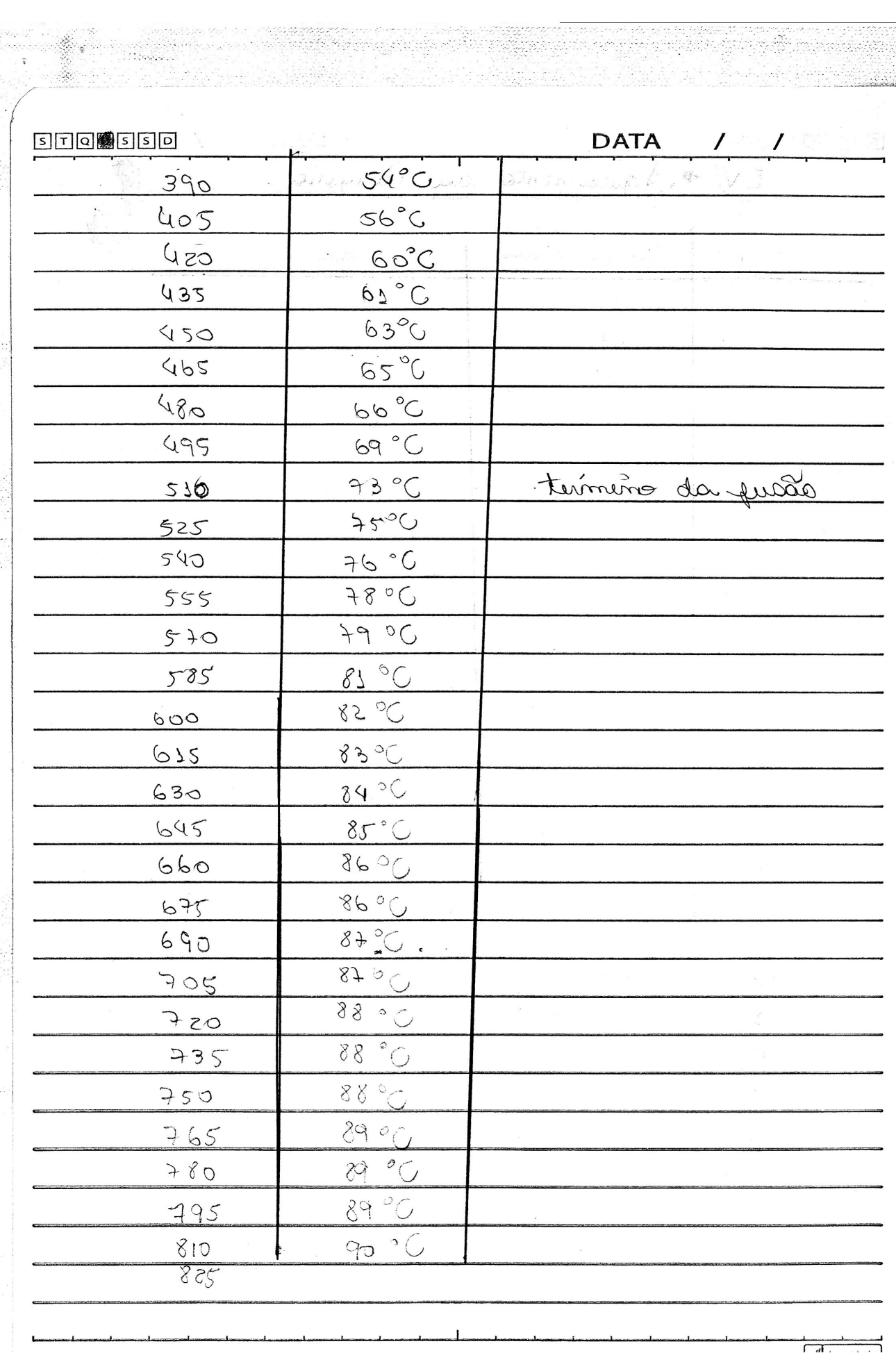




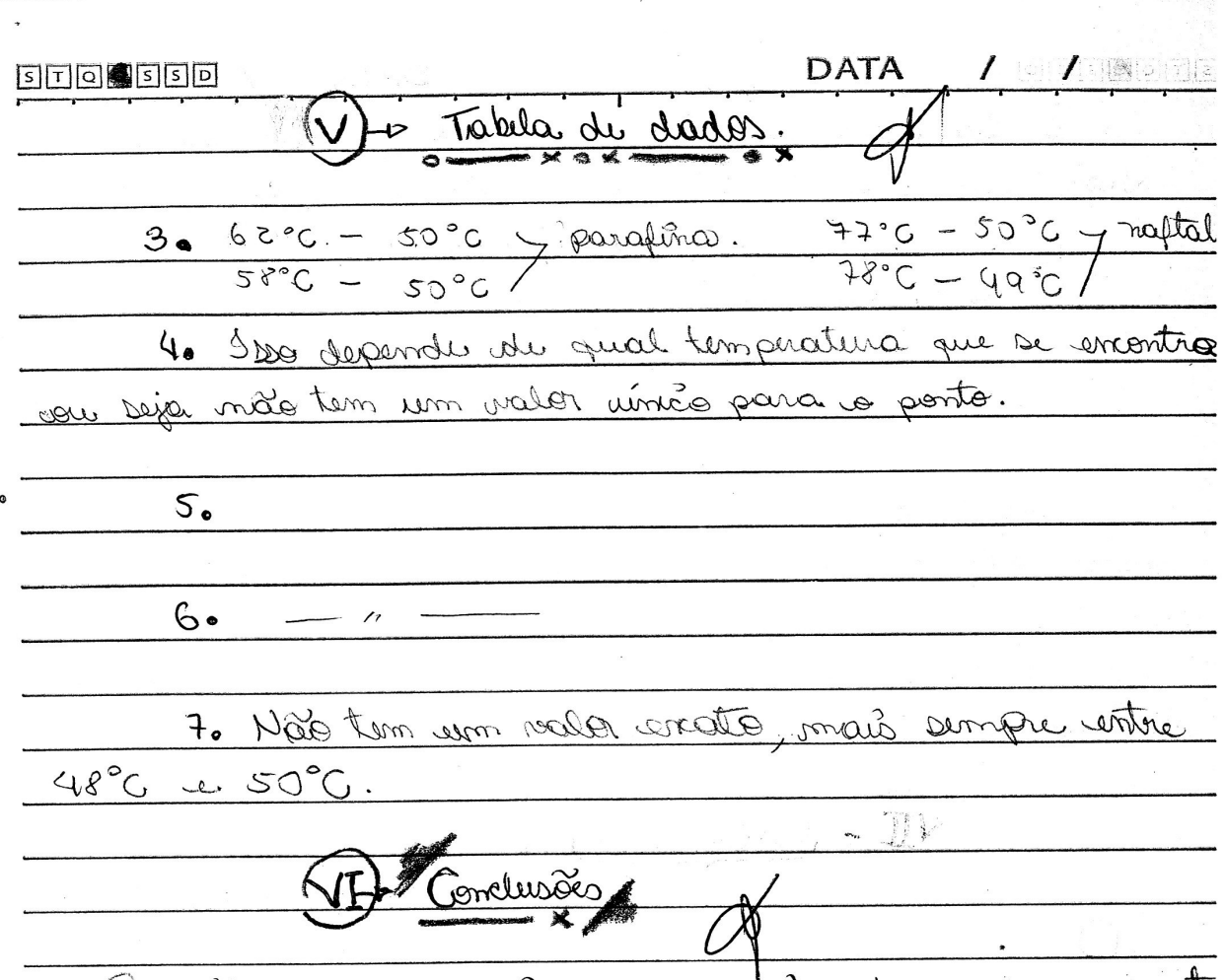

(1) Nö̈o depende, pois de a matérial term paus componinnty centos para que scorra is. Dul portó de Lusäo, a awantidad não írá afutar io perto da fusäo.

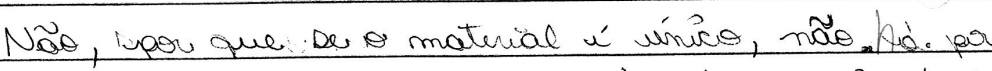
aue be ter mudade de foirmula em diferentes tabricantes, além nue terham muditicade derido a qualaver ciconderieierrio casienada de tipe de locemesôs do mativial no ponto de fusão es materiál de encontra entre liquide-sólide e na solidifúacão e material fica bólide. Pstante nã păe contatis fícicas

Sim, rom extude da substân cia pedemos chegar a vea sizem. 
(5) $\sin$, ar que isoso náo vaiu dipender da sua apuantidade, acsim pacilitomdo es estudo se sua origerm

(6) Sim, asereimadamente.

(1) Através do sew pento de fusão.

(8) Substânicia u'únuca, na qual podemos usar diferenter delas vpara deter um material.

3 mistura u' um conjumto de difurentes romponenteo formande unia mistura

\section{VII $)-\underbrace{\operatorname{coscti0s})}$}

(1) através da obsuriacão dó aquecimento, do estudo de buas pases durante a aquecimento es caracterústitas físicas.

(2) A a,b,cet.

B-d

C- Sim, vaís tem temperatura de tempos

sermikantes.

- na amostra D, pois unäo tem uma tomperatera constante

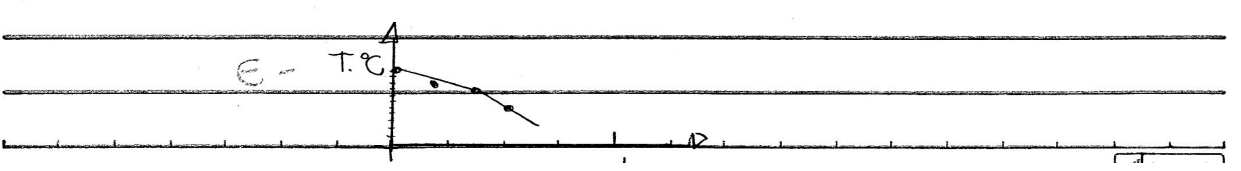




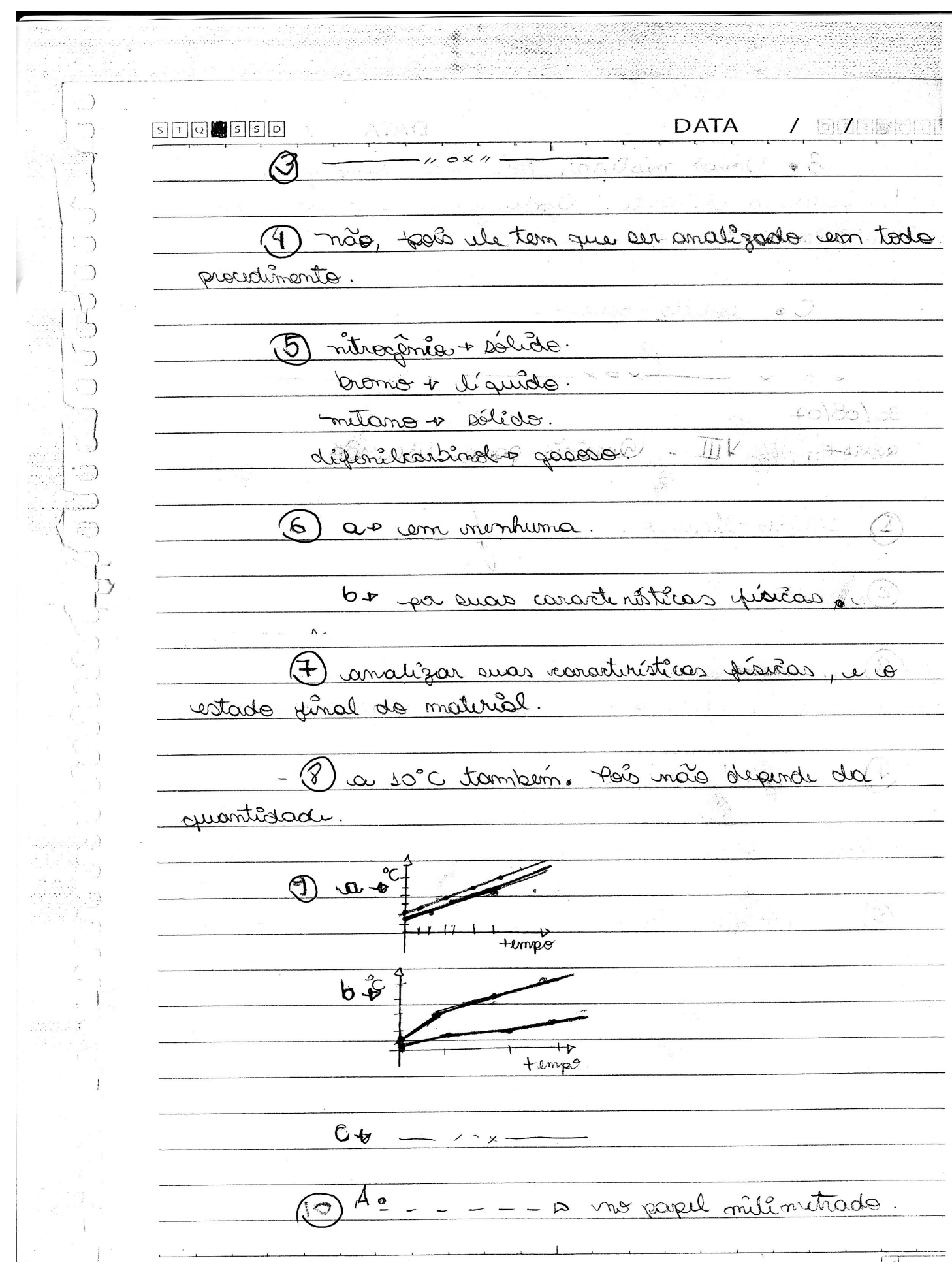




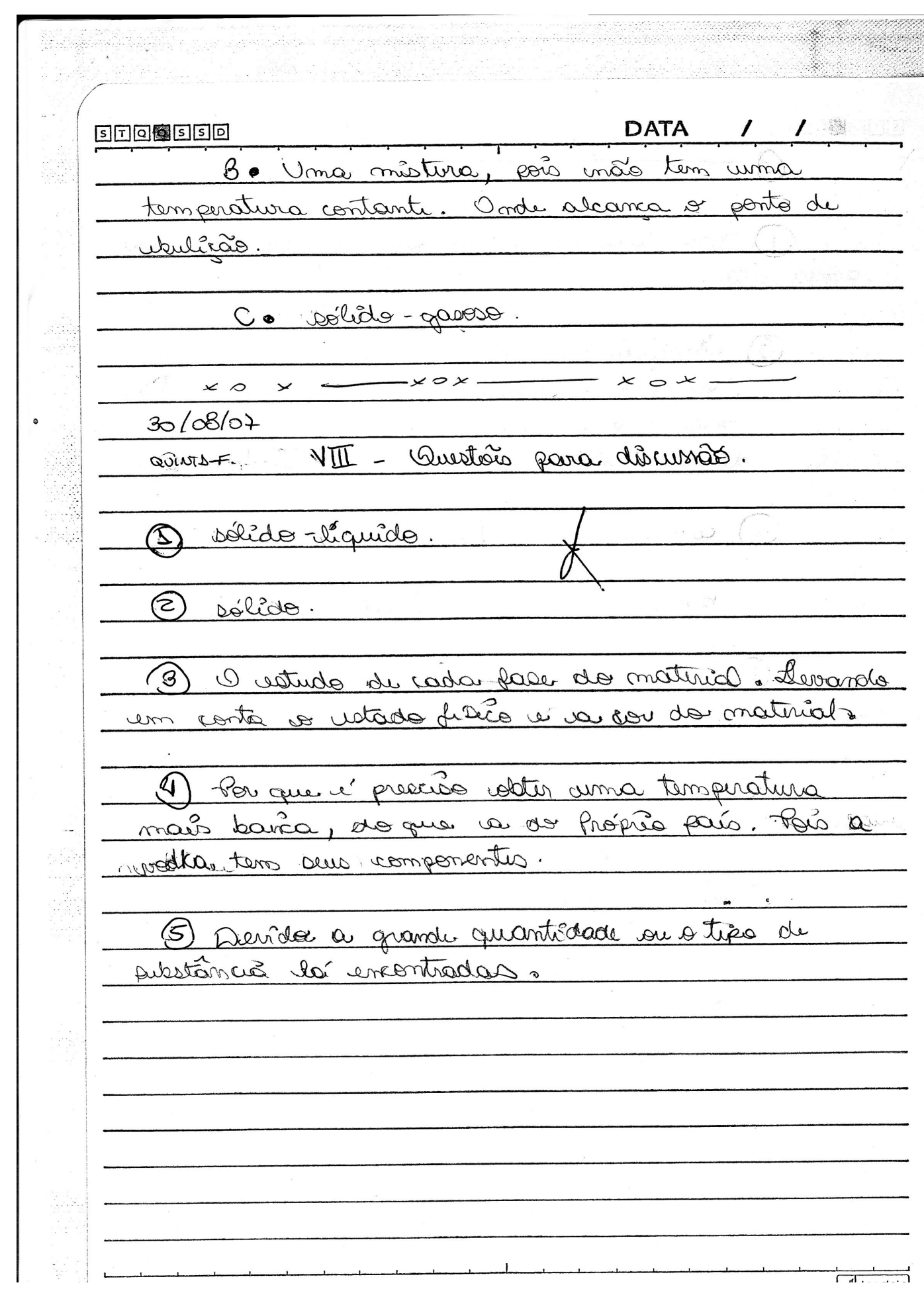




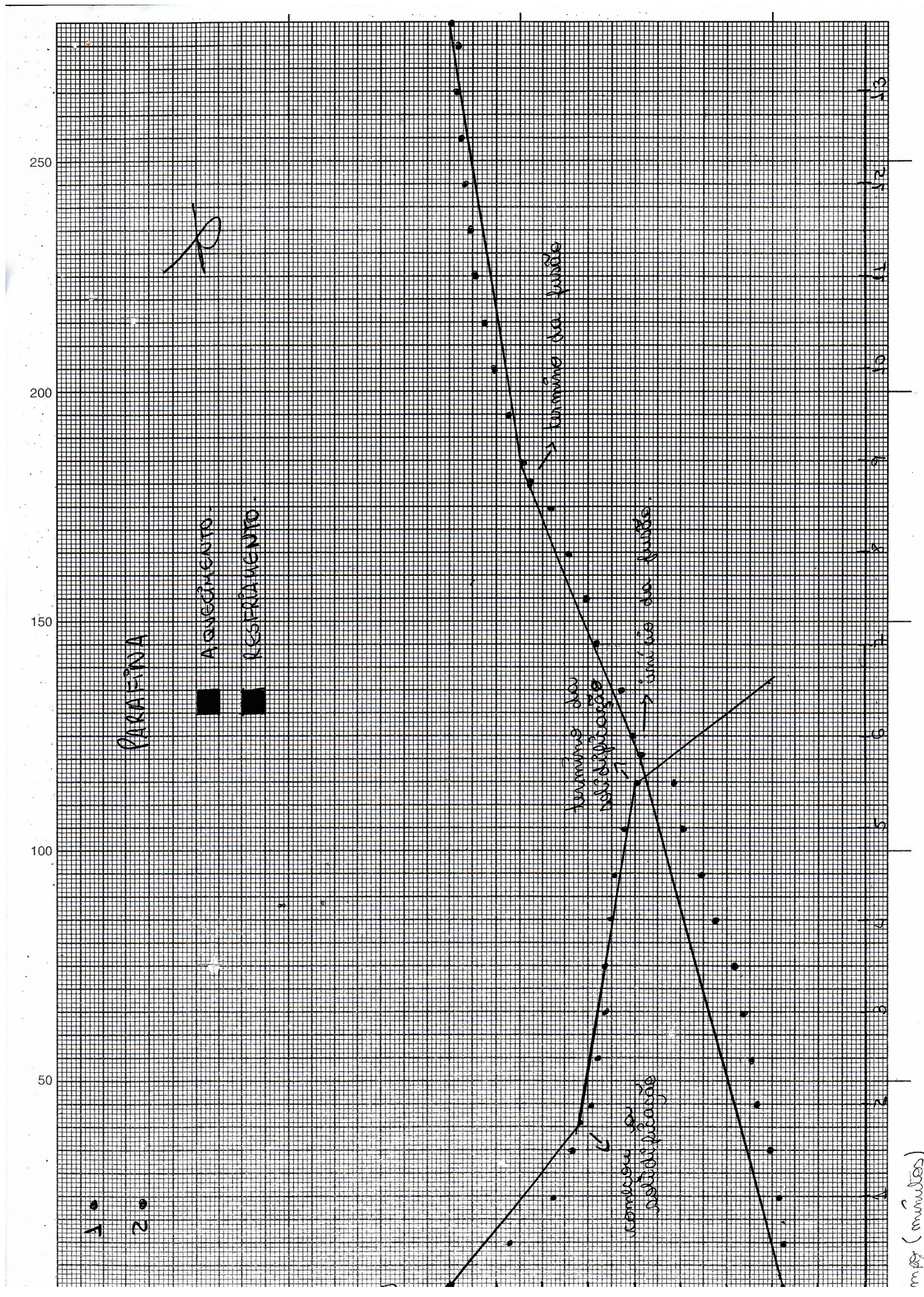

